\title{
Flowers of Evil? Industrialization and Long Run Development*
}

\author{
Raphaël Franck ${ }^{\dagger}$ and Oded Galor ${ }^{\ddagger}$
}

This Version: July 25, 2018

\begin{abstract}
This research explores the effect of industrialization on the process of development. In contrast to conventional wisdom that views industrial development as a catalyst for economic growth, the study establishes that while the adoption of industrial technology was conducive to economic development in the short-run, it has detrimental effects on the standard of living in the long-run. Exploiting exogenous geographic and climatic sources of variation in the diffusion and adoption of steam engines across French departments during the early phases of industrialization, the research establishes that intensive industrialization in the middle of the 19th century increased income per capita in the subsequent decades but diminished it by the turn of the $21^{\text {st }}$ century. The analysis further suggests that the adverse effect of earlier industrialization on long-run prosperity can be attributed to the negative impact of the adoption of unskilled-intensive technologies in the early stages of industrialization on the long-run level of human capital and thus on the incentive to adopt skill-intensive technologies in the contemporary era. Preferences and educational choices of second generation migrants within France indicate that industrialization has triggered a dual techno-cultural lock-in characterized by a reinforcing interaction between technological inertia, reflected by the persistence predominance of low-skilled-intensive industries, and cultural inertia, in the form of a lower predisposition towards investment in human capital. These findings suggest that the characteristics that permitted the onset of industrialization, rather than the adoption of industrial technology per se, have been the source of prosperity among the currently developed economies that experienced an early industrialization. Thus, developing economies may benefit from the allocation of resources towards human capital formation and skilled intensive sectors rather than toward the promotion of traditional unskilled-intensive industrial sectors.
\end{abstract}

Keywords: Economic Growth, Human Capital, Industrialization, Steam Engine, Cultural Inertia.

JEL classification: N33, N34, O14, O33.

${ }^{*}$ The authors are grateful to Daron Acemoglu, Philippe Aghion, Josh Angrist, Emily Blanchard, Francesco Caselli, Martin Fiszbein, Marc Klemp, Tommaso Porzio, Jesse Shapiro, Eve Sihra Colson, Uwe Sunde and David Weil for helpful discussions and participants in seminars and conferences at Ben Gurion University, Brown, Clemson, Haifa, Hebrew University, MIT, UC Merced, the Israel Economic Association, the NBER Meeting of Macroeconomics Across Time and Space, May 2018, and the NBER SI Economic Growth Meeting, July 2018, for useful comments. We thank Guillaume Daudin, Alan Fernihough and Ömer Özak for sharing their data with us. Raphaël Franck wrote part of this paper as Marie Curie Fellow at the Department of Economics at Brown University under funding from the People Programme (Marie Curie Actions) of the European Union's Seventh Framework Programme (FP 2007-2013) under REA Grant agreement PIOF-GA-2012- 327760 (TCDOFT).

${ }^{\dagger}$ The Hebrew University of Jerusalem, Department of Economics, Mount Scopus, Jerusalem 91905, Israel Raphael.Franck@mail.huji.ac.il

‡Brown University, NBER, CEPR, IZA, and CESifo. Oded_Galor@brown.edu. 


\section{Introduction}

The process of development has been marked by persistence as well as reversals in the relative wealth of nations. While some geographical characteristics that were conducive for economic development in the agricultural stage had detrimental effects on the transition to the industrial stage of development, conventional wisdom, as captured by Figure 1, suggests that prosperity has persisted among societies that experienced an earlier industrialization. ${ }^{1}$

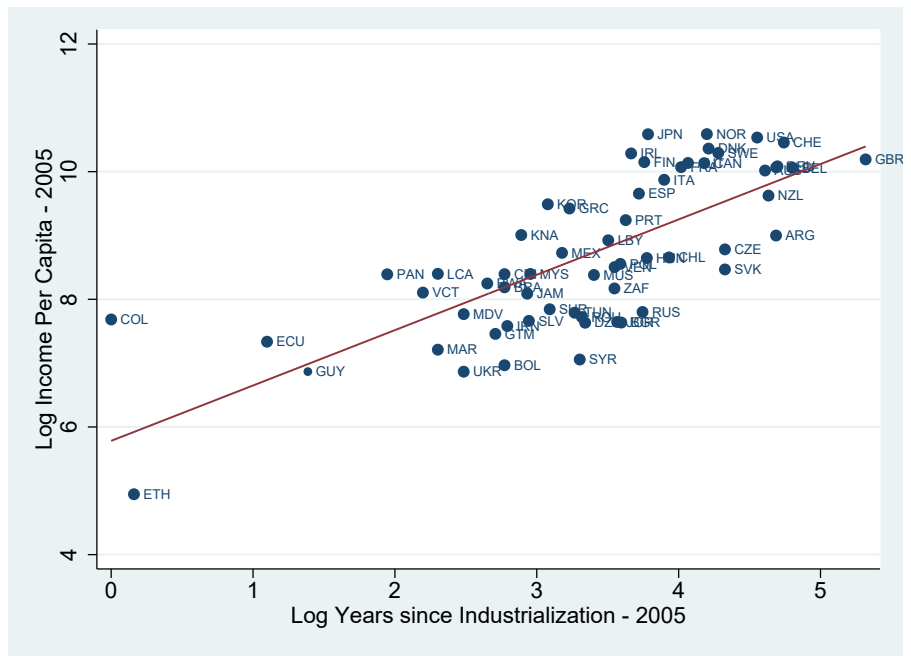

Figure 1: Early industrialization and GDP per capita

$$
\text { Source: Galor (2011). }
$$

Regional development within advanced economies, nevertheless, appears far from being indicative of the presence of a persistent beneficial effect of early industrialization. In particular, anecdotal evidence suggests that regions which were prosperous industrial centers in Western Europe and in the Americas in the $19^{\text {th }}$ century (e.g., the Rust Belt in the USA, the Midlands in the UK, and the Ruhr valley in Germany) have experienced a reversal in their comparative development.

These conflicting observations about the long-run effect of industrialization on the prosperity of regions and nations may suggest that factors which fostered industrial development in the Western world, rather than the forces of industrialization per se, are associated with the persistence of fortune across these industrial nations. In particular, it is not inconceivable that the process of industrialization per se, despite its earlier virtues, has had detrimental effects on the transition to the post-industrial stage of development and on long-run prosperity. Nevertheless, despite the enormous importance of the resolution of this question from a policy perspective, to a large extent, this issue has, neither been raised nor been explored in the modern economic growth literature.

The research explores the long-run implications of industrialization on the process of development. It

\footnotetext{
${ }^{1}$ The persistence effect of geographical, cultural, institutional and human characteristics have been at the center of a debate regarding the origins of the differential timing of transitions from stagnation to growth and the remarkable transformation of the world income distribution in the last two centuries (e.g., Acemoglu et al. (2001), Galor (2011), Andersen et al. (2016), Ashraf and Galor (2013), Cervellati and Sunde (2005), Dalgaard and Strulik (2016), Galor and Özak (2016), Litina (2016), Mokyr (2016)).
} 
addresses two fundamental questions: (i) is industrialization conducive for long-run prosperity? and (ii) are the industrialized nations richer because of industrialization or perhaps despite industrialization? In contrast to conventional wisdom that views industrial development as a catalyst for economic growth, highlighting its persistent effect on economic prosperity, the study advances the hypothesis and establishes empirically that while the adoption of industrial technology was conducive for economic development in the short-run, acquired comparative advantage in the unskilled-intensive industrial sector had triggered cultural inertia, characterized by a lower predisposition towards investment in human capital, that has hindered the transition to more lucrative skilled-intensive sectors, adversely effecting human capital formation and the standards of living in the long-run.

A conclusive exploration of the impact of industrialization on long-run prosperity ought to overcome significant empirical hurdles. First, the observed relationship between industrialization and the development process may reflect the reverse causality from the process of development to industrialization rather than the effect of industrialization on the process of development. Second, the effect of institutional, cultural, geographical and human characteristics on the joint evolution of industrialization and the process of development may have governed the observed relationship between industrialization and the development process. Third, the time since industrialization in a large number of regions and countries is shorter than needed to assess the potential adverse effects of industrialization on long-run prosperity.

In light of these empirical hurdles, the desirable empirical framework will be an economy in which: (i) the territory has been divided into administrative units in which institutional, cultural, human and geographical characteristics are unlikely to differ significantly, (ii) the creation of administrative units preceded the process of industrialization and is orthogonal to the subsequent process of industrialization, (iii) industrialization has occurred sufficiently early so as to permit the exploration of its potential adverse long-run effects, (iv) exogenous source of regional variation in the intensity of industrialization could be identified, and (iv) extensive data on the process of development since early industrialization is available.

The economy of France appears ideally suited for this empirical exploration for these reasons. First, as early as 1790, the French territory was divided into administrative units (departments) of nearly equal size, designed to ensure that travel distance by horse from any location within the department to the main administrative center would not exceed one day. Hence, one can plausibly argue that the borders of each department were orthogonal to the process of industrialization. Second, French departments have been subjected to an intensive institutional and cultural unification that mitigated initial cultural differences across these regions. Third, France was one of the first European countries to industrialize and the extended period since its industrialization is sufficiently long to permit the detection of its potential adverse effect on long-run prosperity. Fourth, exogenous sources of variation in the intensity of industrialization across department could be detected. Finally, the availability of extensive data on the time paths of income per capita, human capital formation, wages, sectoral employment, unionization rates, tariff protection, economic integration and the availability of natural resources across departments permits the examination of the proposed channels through which the adverse effect of industrialization may have operated.

The study utilizes French regional data from the second half of the $19^{\text {th }}$ century until the beginning of the $21^{\text {st }}$ century to explore the impact of the adoption of industrial technology on the evolution of income per capita. It establishes that regions which industrialized more intensively experienced higher income per 
capita in the subsequent decades. Nevertheless, industrialization has had an adverse effect on income per capita by the turn of the $21^{\text {st }}$ century.

The identification strategy consists of two distinct components that govern: (i) the regional diffusion and thus the supply of industrial technologies, and (ii) the differential decline in the profitability of the agriculture sector across regions and thus variations in the pace of industrialization and the demand for industrial technologies. First, in light of the association between industrialization and the intensity of the use of the steam engine (Mokyr, 1990; Bresnahan and Trajtenberg, 1995; Rosenberg and Trajtenberg, 2004), the study takes advantage of historical evidence regarding the regional diffusion of the steam engine (Ballot, 1923; Sée, 1925; Léon, 1976) to identify the effect of regional variations in the intensity of the use steam engine in 1860-1865 on the process of development. In particular, it exploits the distances of each French department from Fresnes-sur-Escaut, where a steam engine was first successfully operated for commercial use from 1732 onwards, as exogenous source of variations in industrialization across French regions. ${ }^{2}$ Second, the study exploits contemporaneous regional variations in temperature deviations from their historical trend to capture exogenous sources of variation in the profitability of agriculture and therefore the pace of industrialization and the demand for steam engine technologies across regions.

Indeed, in line with the historical account, the unequal distribution of steam engines across French departments is indicative of a local diffusion process from Fresnes-sur-Escaut. Accounting for confounding geographical and institutional characteristics, pre-industrial development as well as distances from major economic centers, if the distance of a department away from Fresnes-sur-Escaut was to increase from the 40 th $(426 \mathrm{~km})$ to the 60 th percentile $(559 \mathrm{~km})$ of the distance distribution, this department would experience a drop of 275 horse power of steam engines (relative to a sample mean of $1839 \mathrm{hp}$ ) in the 1860-1865 industrial survey.

The validity of the distance from Fresnes-sur-Escaut as an instrumental variable for the intensity of the adoption of steam engines across France is enhanced by three additional factors. First, conditional on the distance between each department and Fresnes-sur-Escaut, distances from major centers of economic power in 1860-1865 (e.g., Paris, Marseille, Lyon, Rouen, Mulhouse, Bordeaux, Berlin and London) are uncorrelated with the intensive use of the steam engine over this period. Second, the distance from Fresnessur-Escaut is uncorrelated with the level and the growth rate of economic development across France in the pre-industrial period. Third, it appears that the Nord department (where Fresnes-sur-Escaut is located) had neither superior human capital characteristics nor higher standard of living in comparison to the average department in France.

Furthermore, regional variations in temperature deviations from their historical trend in the years that preceded the industrial survey is associated with regional variation in the profitability of agriculture (as reflected by wheat prices), and in the reduced incentive to adopt the steam engine. In particular, conditional on the distance from Fresnes-sur-Escaut, in comparison to a department at the 40th percentile of the squared temperature deviation (i.e., 0.14), a department with a 60th percentile of the squared temperature deviation

\footnotetext{
${ }^{2}$ In 1726, an Englishman named John May obtained a privilege to operate steam engines to pump water throughout the French kingdom. Jointly with another Englishman named John Meeres, he installed the first steam engine in Passy (which was then outside but is now within the administrative boundaries of Paris) to raise water from the Seine river to supply the French capital with water. However it seems that their commercial and industrial operation stopped quickly or even never took off. Indeed, when Forest de Bélidor (1737) published his massive treatise on engineering in 1737-1739, he mentioned that the steam engine in Fresnes-sur-Escaut was the only one operated in France (see, e.g., Lord (1923) and Dickinson (1939)).
} 
(i.e., 0.25), will be expected to experience a drop of 13.9 in the horse power of steam engines. These estimates suggest that, while the diffusion of the steam engine as well the transition from agriculture to industry contributed to the adoption of steams engines, the effect of gradual diffusion of steam engines from the North of France to the rest of the country dominated the effect of climatic volatility on the slower transition of French regions from agriculture to industry in the 19th century.

The study establishes that the horse power of steam engines in industrial production in the 1860-1865 period had a positive and significant impact on income per capita in 1860, 1901 and 1930. In particular, a one-percent increase in the total horse power of steam engines in a department in 1860-1865 increased GDP per capita by 0.10 percent in 1860, 0.23 percent in 1901 and 0.10 percent in 1930 . Nevertheless, industrialization had an adverse effect on income per capita and human capital formation in the post-2000 period. In particular, a one-percent increase in the total horse power of steam engines in a department in 1860-1865 led to a 0.06 percent decrease in GDP per capita in 2001-2005. ${ }^{3}$

It is important to note that the IV estimation reverses the OLS estimates of the relationship between industrialization and the long-run level of income per capita from a positive to a negative one. This reversal suggests that factors which fostered industrial development, rather than industrialization per se, contributed to the positive association between industrialization and long-run development. In particular, once one accounts for the effect of these omitted factors, industrialization has an adverse effect on the standard of living in the long-run. These findings suggest that the characteristics that permitted the early onset of industrialization, rather than the adoption of industrial technology per se, have been the source of prosperity among the currently developed economies that experienced an early industrialization.

The empirical analysis accounts for a wide range of exogenous confounding geographical and institutional characteristics, as well as for pre-industrial development, which may have contributed to the relationship between industrialization and economic development. First, it accounts for the potentially confounding impact of exogenous geographical characteristics (i.e, latitude, land suitability, average temperature, average rainfall and share of carboniferous area) of each French department on the relationship between industrialization and economic development. In particular, it captures the potential effect of these geographical factors on the profitability of the adoption of the steam engine, the pace of its regional diffusion, as well as on productivity and thus the evolution of income per capita in the process of development. Second, it captures the potentially confounding effects of the location of departments (i.e., border departments, maritime departments, departments at a greater distance from the concentration of political power in Paris, and those that were temporarily under German domination) on the diffusion of the steam engine and the diffusion of development. Third, the analysis accounts for the differential level of development across France in the preindustrial era that may have affected jointly the process of development and the process of industrialization.

If one views each French department as a small open economy, one may argue that the proper industrial policy ought to encourage the development of skilled-intensive sectors rather than of traditional unskilledintensive sectors. However, one concern could be that the negative effect of industrialization in the long-run, at the departmental level, does not reflect the overall effect of industrialization. A priori, it is possible that industrialization generated technological spillovers such that the most industrialized department within a

\footnotetext{
${ }^{3}$ To put these figures in perspective, it must be borne in mind that Crafts (2004) finds that the contribution of steam technology to labor productivity growth in Great Britain was equal to 0.41 percent per year over the $1850-1870$ period and to 0.31 percent per year over the $1870-1910$ period.
} 
region declined but the region as a whole prospered due to the spillovers from the process of industrialization. Nevertheless, further empirical analysis suggests that the negative impact of industrialization on long-run prosperity in one department did not generate sufficiently positive spillovers in neighboring departments so as to avert the adverse effects of industrialization on long-run prosperity of the region as a whole.

The research further explores the mediating channels through which earlier industrial development has an adverse effect of the contemporary level of development. It suggests that the adverse effect of industrialization on long-run prosperity reflects the adverse effect of earlier specialization in unskilled-intensive industries on human capital formation and the incentive to adopt skill-intensive technologies in the contemporary era. Industrialization has triggered a dual techno-cultural lock-in effect characterized by a reinforcing interaction between technological inertia, reflected by the persistence predominance of low-skilled-intensive industries and cultural inertia, in the form of a lower predisposition towards investment in human capital. In particular, while the adoption of industrial technology was conducive for economic development in the short-run, acquired comparative advantage in the unskilled-intensive industrial sector had triggered cultural inertia, characterized by lower educational aspirations, that has hindered the transition to more lucrative skilled-intensive sectors, adversely effecting human capital formation and the standards of living in the long-run.

The dual technological-cultural lock-in effect is established using individual level data. Following the epidemiological approach for the study of cultural persistence, the study exploits data on education achievements of over 2100 second generation migrants (i.e., individuals who live in their birth department and their parents migrated from a different department within France). The analysis suggests that second generation migrants whose parents were originated in historically industrial regions are significantly more likely to have low human capital aspirations, as reflected by their acquisition of vocational education, accounting for the department of birth fixed effects and for the parental occupation. The analysis of second-generation migrants accounts for time invariant unobserved heterogeneity in the host department (e.g., geographical, cultural and institutional characteristics), mitigating possible concerns about the confounding effect of host departmentspecific characteristics. Moreover, since the historical industrial intensity in the parental department of origin is distinct from the historical industrial intensity in the respondent's department of residence, the estimated effect of industrial intensity in the parental department of origin on their human capital formation captures the culturally-embodied, intergenerationally transmitted effect of industrial intensity on human capital aspirations, rather than the direct effect of industrial intensity. This result lend credence to the presence of cultural inertia and technological inertia that have reinforced one another and triggered a dual lock-in effect.

Furthermore, using individual data on the composition of employment across sectors among over 1.1 million individuals, the study suggests that this cultural inertia, and its adverse effect on human capital formation in the long-run, has further hindered the incentive of competitive industries to adopt more lucrative skilled-intensive technologies, reinforcing the suboptimal level of human capital formation and reducing the standards of living in the long-run. In particular, individuals who are currently residing in a department that was characterized in the 1860-1865 survey by a higher horse power of steam engine are significantly less likely to be employed in the skill-intensive $R \& D$ sector and are significantly more likely to be employed in unskilled-intensive industrial sectors. These results lend credence to the argument that historical industrial regions have experienced a technological lock-in effect. Namely, acquired comparative advantage in the unskilled-intensive sector in early stages of industrialization is associated with the relative domination of 
unskilled intensive firms and occupations.

The empirical analysis further establishes that various plausible channels do not account for the adverse effect of early industrialization on long-run prosperity: (1) the contribution of industrialization to unionization and wage rates in historically industrialized regions and the comparative decline of these regions in the long-run due to the incentive of modern industries to locate in regions where labor markets are more competitive, (2) the effect of trade protection in traditional industries on the decline in the long-run competitiveness of historically industrialized regions, (3) the potential negative effect of disproportional destruction of industrialized regions during WWI and WWII on the subsequent development of these regions, (4) the persistent ad- verse effect of selective migration (e.g. immigration of unskilled workers into industrialized regions, or the emigration of more educated workers into less industrialized regions), on the composition of human capital and long-run income per capita in historically industrialized regions, and (5) the disproportionate public investment in human capital in non-industrial regions.

\section{Data and Main Variables}

France was among the first countries to industrialize in Europe in the 18th century and its industrialization continued during the 19th century. Nevertheless, by 1914, the living standard in France remained below that of England and of Germany, which had become the leading industrial country in continental Europe. The slower path of industrialization in France has been attributed to the consequences of the French Revolution (e.g., wars, legal reforms and land redistribution), the patterns of domestic and foreign investment, cultural preferences for public services, as well as the comparative advantage of France in agriculture vis-a-vis England and Germany (see the discussion in, e.g., Crouzet, 2003).

This section examines the evolution of industrialization and income across 89 French departments, based on the administrative division of France in the 1860-1865 period, accounting for the geographical and the institutional characteristics of these regions. The initial partition of the French territory in 1790 was designed to ensure that the travel distance by horse from any location within the department to the main administrative center would not exceed one day. The initial territory of each department was therefore orthogonal to the process of development and the subsequent minor changes in the borders of some departments did not reflect the effect of industrialization.

In light of the changes in the internal and external boundaries of the French territory during the period of study, the number of departments that is included in different stages of the analysis varies from 81 to 89. In particular, several departments that were split into smaller units are aggregated into their historical territorial borders and regions that were temporarily removed from the French territory are excluded from the analysis during those time periods. ${ }^{4}$ Table A.1 reports the descriptive statistics for the variables in the empirical analysis across these departments.

\footnotetext{
${ }^{4}$ The Parisian region encompassed three departments (Seine, Seine-et-Marne and Seine-et-Oise) before 1968 and it was split into eight (Essonne, Hauts-de-Seine, Paris, Seine-et-Marne, Seine-Saint-Denis, Val-de-Marne, Val d'Oise and Yvelines) afterwards. Likewise, the Corsica department was split in 1975 into Corse-du-Sud and Haute-Corse. The three departments (i.e., Bas-Rhin, Haut-Rhin and Meurthe) which were under German rule between 1871 and 1918 are excluded from the analysis of economic development over that time period. In addition, in the examination of the robustness of the analysis with data prior to 1860, the three departments (i.e., Alpes-Maritimes, Haute-Savoie and Savoie) that were not part of France are excluded from the analysis.
} 


\subsection{Past and Present Measures of Income, Workforce and Human Capital}

\subsubsection{Income}

This study seeks to examine the effect of industrialization on the evolution of income per capita in the process of development. Given that the industrial survey which is the basis for our analysis was conducted between 1860 and 1865, the relevant data to capture the short-run and medium-run effects of industrialization on income per capita are provided at the departmental level prior to WWII for the years 1860, 1872, 1886, 1901, 1911 and 1930 by Combes et al. (2011) and Caruana-Galizia (2013). Thus, for the sake of brevity, and equal spacing between those years, the analysis focuses on income per capita in 1860, 1901 and 1930.

To assess the effects of industrialization on income per capita in the long-run, the analysis is restricted to the 2001-2005 period (INSEE - Institut National de la Statistique et des Etudes Economiques). ${ }^{5}$ Moreover, to lessen the potential impact of fluctuations in income per capita, the effect of industrialization in the long-run is captured by its differential impact on the average GDP per capita across departments over the 2001-2005 period.

\subsubsection{Workforce}

The effect of industrialization on the sectoral composition of the workforce in the post-1860 period is captured by the impact on the shares of employment in the agricultural, industrial and service sectors. The surveys which capture the short-run and mid-run effects of industrialization are those undertaken in 1861, 1901 and 1930 (Statistique Générale de la France). Similarly, to assess the effects of industrialization on the sectoral composition in the post-WWII period, all available surveys of the French population across departments (i.e., 1968, 1975, 1982, 1990, 1999 and 2010) are used (INSEE - Institut National de la Statistique et des Etudes Economiques).

Furthermore, the analysis of the underlying mechanism uses individual data from the Déclaration Annuelle de Donnés Sociales in 2008 which provides representative information on 1.1 million private sector workers, except for the self-employed. This dataset enables us to determine whether individuals are more likely to work in firms where the demand for human capital is high (i.e., scientific research \& development) or low (i.e., coal industries or machine repair.) In addition, the analysis relies on the 2005 survey Enquête Emploi conducted by the INSEE regarding the job prospects of employed and unemployed individuals. This survey provides information on the respondents' birthplace as well as those of their parents. As such, it enables us to focus on second generation migrants (i.e., individuals who were born and still live in their birth department, but whose parents were born in a different department). In the analysis, these second generation migrants are matched to the horse power of steam engines of their mother's birth department, their father's birth department, as well as to the birth department of their parents if both of them were born in the same department.

\footnotetext{
${ }^{5}$ Data on income per capita at the departmental level is only available in the post-1995 period and the corresponding data for the other indicators of the standards of living only in the post-2001 period. Note that the qualitative results remain unchanged if one considers the average income per capita over the entire sample period available, 1995-2010.
} 


\subsubsection{Human Capital}

The study further explores the effect of industrialization on the evolution of human capital in the process of development. The effect of industrialization on human capital formation in the pre-WWI period is captured by its impact on the literacy rates of French army conscripts (i.e., 20-year-old men who reported for military service in the department where their father lived - Annuaire Statistique De La France (1878-1939)). In particular, given the data limitations, the analysis focuses on the share of the literate conscripts over the 1874-1883 and 1894-1903 decades. As reported in Table A.1, 82.0\% of the French conscripts were literate over the 1874-1883 period and $94.1 \%$ over the $1894-1903$ period. ${ }^{6}$

The effect of industrialization on human capital formation in the post-WWII period is captured by its impact on the share of men and women (age 25 and above) who completed a post-secondary degree (in a vocational school or in an university) as reported in the available surveys of the French population across departments (i.e., 1968, 1975, 1982, 1990, 1999 and 2010). As can be seen in Table A.1, there was a continuous increase in the educational achievements of the French population during this period. Indeed the shares of men and women (age 25 and above) who completed high-school, respectively, rose from $8.8 \%$ and $6.0 \%$ in 1968 to $36.3 \%$ and $39.1 \%$ in 2010 .

Furthermore, to examine the role of the composition of human capital in the non-monotonic evolution of income per capita, the study explores the impact of industrialization on the evolution of high-, mediumand low-levels of human capital in France after WWII . This composition is captured by the division of the workforce (age 25-54) between executives and other intellectual professions, middle management professionals, and employees, in the available surveys of the French population across departments $(1968,1975,1982$, 1990, 1999 and 2010).

Moreover, to capture the effect of industrialization on human capital formation in the contemporary period, in which school attendance is mandatory until the age of 16, the study explores its impact on the shares of men and women in the 15-17 and 18-24 age categories attending school or any other (postsecondary) learning institution as reported in the 2010 census. As indicated in Table A.1, in 2010, most men and women age 15-17 (respectively $95.5 \%$ and $96.7 \%$ ) attended school but fewer (44.3\% and $48.0 \%$ ) pursued post-secondary studies.

Finally, to capture the general willingness of the local population to invest in human capital, we use individual data from a 2001 survey pertaining to the importance that individuals attribute to science and scientific research (Centre de recherches politiques de Sciences Po, Enquête science 2001). Out of the various questions, we single out two where individuals are asked whether they have an interest in science or not, and whether they use science in their current work.

\subsection{Steam Engines}

The research explores the effect of the introduction of industrial technology on the process of development. In light of the pivotal role played by the steam engine in the process of industrialization, it exploits variations in the industrial use of the steam engine across the French regions during its early stages of industrialization

\footnotetext{
${ }^{6}$ In line with the historical evidence (e.g., Grew and Harrigan, 1991), as reported in Table A.1, a sizeable share of the French population was literate even before the passing of the 1881-1882 laws which made primary school attendance "free" and mandatory for boys and girls until age 13 .
} 
to capture the intensity of industrialization. In particular, the analysis focuses on the horse power of steam engines used in each French department as reported in the industrial survey carried out by the French government between 1860 and $1865 .^{7}$

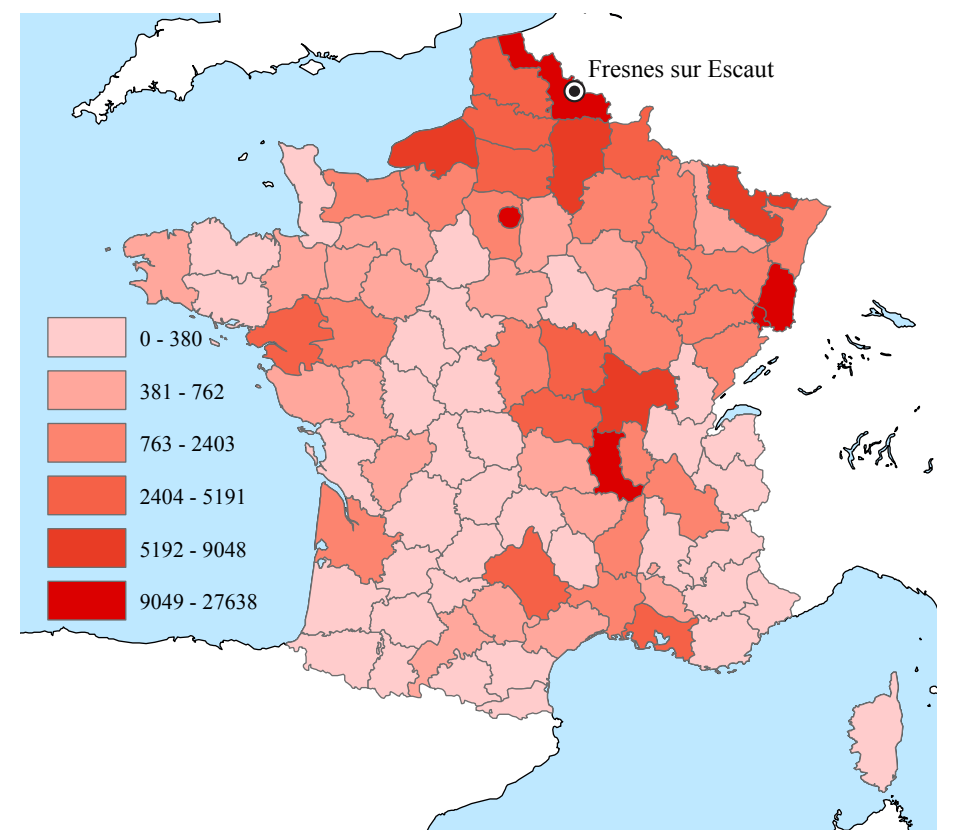

Figure 2: The distribution of the total horse power of steam engines across departments in France, 1860-1865.

As depicted in Figure 2, and analyzed further in the discussion of the identification strategy in Section 3 , the unequal distribution of the steam engines across French departments in 1860-1865 suggests a regional pattern of diffusion from Fresnes-sur-Escaut (in the Nord department, at the northern tip of continental France) where a steam engine was first successfully operated for commercial and industrial purposes in France from 1732 onwards. The most intensive use of the steam engine over this period was in the Northern part of France. The intensity diminished somewhat in the East and in the South East, and declined further in the South West. Three departments had no steam engine in 1860-1865 (i.e., Ariège and Lot in the South-West and Hautes-Alpes in the South-East). Potential anomalies associated with these departments are accounted for by the introduction of a dummy variable that represents them. In particular, potential concerns about the distance of these departments from the threshold level of development that permits the adoption of the steam engines is accounted for by this dummy variable.

Table A.6 reports descriptive statistics for the horse power of steam engines in each of the 16 sectors listed in the 1860-1865 survey: ceramics, chemistry, clothing, construction, food, furniture, leather, lighting, luxury goods, metal objects, metallurgy, mines, sciences \& arts, textile, transportation and wood. It shows that the five sectors with the largest mean horse power per department are textile, metallurgy, mines, food industry and metal objects. In particular, the textile sector had the largest average horse power of all the

\footnotetext{
${ }^{7}$ The 1860-1865 survey is the second industrial survey undertaken in France which was published by the French government: it provides the horse power of steam engines but not the number of steam engines. Conversely, the first industrial survey, which was carried out in 1839-1847, indicates the number of steam engines but not the horse power of the steam engines. Below, we establish the robustness of the results to using the 1839-1847 data, as well data from 1897.
} 
sectors and $43 \%$ more horse power than metallurgy, the sector with the second largest mean horse power. Moreover, using the descriptive statistics on the number of workers in each of the 16 sectors reported in Table A.6 that the textile sector has a smaller ratio of steam engine horse power per worker than the metallurgy, mining and food sectors, most likely because not all the activities of the textile sector required steam engines.

\subsection{Confounding Characteristics of each Department}

The empirical analysis accounts for a wide range of exogenous confounding geographical and institutional characteristics, as well as for pre-industrial development, which may have contributed to the relationship between industrialization and economic development. Institutions may have affected jointly the process of development and the process of industrialization. Geographical characteristics may have impacted the pace of industrialization as well as agricultural productivity and thus income per capita. Moreover, geographical and institutional factors may have affected the process of development indirectly by governing the pace of the diffusion of steam engines across departments. Finally, pre-industrial development may have affected the onset of industrialization and may have had an independent persistent effect on the process of development.

\subsubsection{Geographic Characteristics}

The empirical analysis accounts for the potentially confounding impact of exogenous geographical characteristics of each of the French departments on the relationship between industrialization and economic development. In particular, it captures the potential effect of these geographical factors on the profitability of the adoption of the steam engine, the pace of its regional diffusion, as well as on productivity and thus the evolution of income per capita in the process of development.

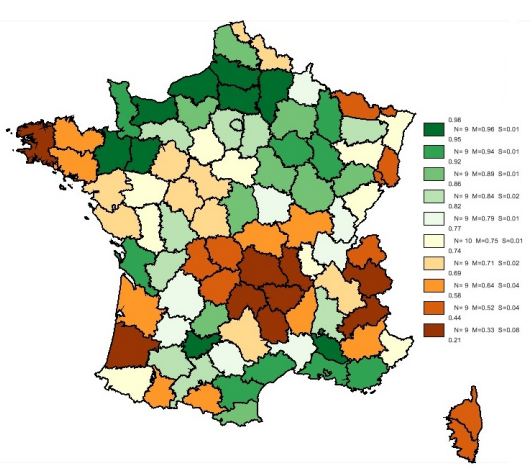

Land Suitability

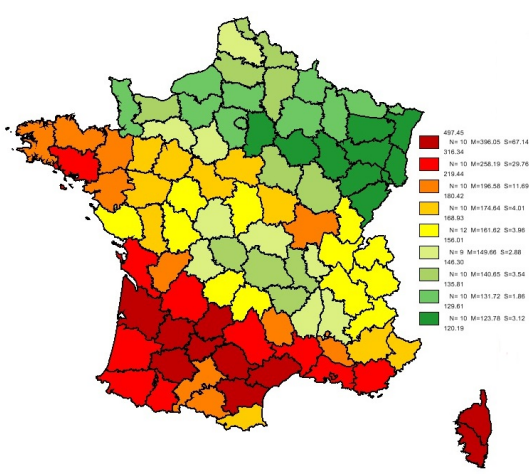

Average Rainfall

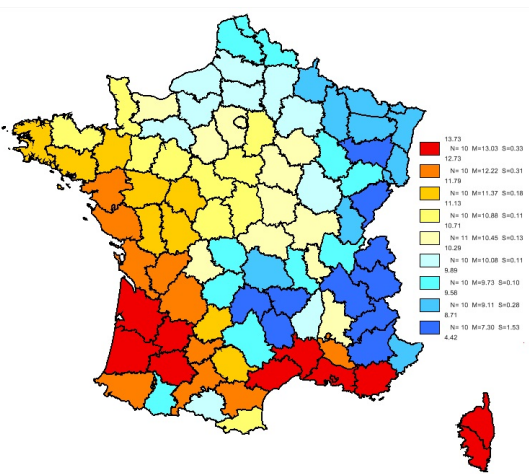

Average Temperature

Figure 3: Geographic characteristics of French departments

First, the study accounts for climatic and soil characteristics of each department mapped in Figure 3 (i.e., land suitability, average temperature, average rainfall, and latitude (Ramankutty et al., 2002; Luterbacher et al., 2004, 2006; Pauling et al., 2006)), that could have affected natural land productivity and therefore the feasibility and profitability of the transition to the industrial stage of development, as well as the evolution of aggregate productivity in each department. Moreover, the diffusion of the steam engine 
across French departments as well as the process of development could have been affected by the presence of raw material required for industrialization. Our regressions thus account for the share of carboniferous area in each department (Fernihough and O'Rourke, 2014).

Second, the analysis captures the confounding effect of the location of each department on the diffusion of development from nearby regions or countries, as well as its effect on the regional diffusion of the steam engine. In particular, it accounts for the effect of the latitude of each department, border departments (i.e., positioned along the border with Belgium, Luxembourg, Germany, Switzerland, Italy and Spain), and maritime departments (i.e., positioned along the sea shore of France) on the pace of this diffusion process. It also accounts for the presence of rivers and their main tributaries within the perimeter of the department by using data on the paths of the Rhine, Loire, Meuse, Rhône, Seine and Garonne rivers as well as of their major tributaries (Dordogne, Charente and Escaut).

Finally, the research accounts for the potential differential effects of international trade on process of development as well as on the adoption the steam engine. In particular, it captures the potential effect of maritime departments (i.e., those departments that are positioned along the sea shore of France), via trade, on the diffusion of the steam engine and thus on economic development as well as the effect of trade on the evolution of income per capita over this time period.

\subsubsection{Institutional Characteristics}

The analysis deals with the effect of variations in the adoption of the steam engine across French departments on their comparative development. This empirical strategy ensures that institutional factors that were unique to France as a whole over this time period are not the source of the differential pattern of development across these regions. Nevertheless, two regions of France over this time period had a unique exposure to institutional characteristics that may have contributed to the observed relationship between industrialization and economic development.

First, the emergence of state centralization in France, centuries prior to the process of industrialization, and the concentration of political power in Paris, may have affected differentially the political culture and economic prosperity in Paris and its suburbs (i.e., Seine, Seine-et-Marne and Seine-et-Oise). Hence, the empirical analysis includes a dummy variable for these three departments, accounting for their potential confounding effects on the observed relationship between industrialization and economic development, in general, and the adoption of the steam engine, in particular. Moreover, the analysis captures the potential decline in the grip of the central government in regions at a greater distance from Paris, and the diminished potential diffusion of development into these regions, accounting for the effect of the aerial distance between the administrative center of each department and Paris.

Second, the relationship between industrialization and development in the Alsace-Lorraine region (i.e., the Bas-Rhin, Haut-Rhin and the Moselle departments) that was under German domination in the 1871-1918 period may represent the persistence of institutional and economic characteristics that reflected their unique experience. ${ }^{8}$ Hence, the empirical analysis includes a dummy variable for these regions, accounting for the

\footnotetext{
${ }^{8}$ Differences in the welfare laws and labor market regulations in Alsace-Lorraine and the rest of France persisted throughout most of the $20^{t h}$ century. Moreover the laws on the separation of Church and State are different, and these differences were reaffirmed by a decision of the Supreme French Constitutional Court in 2013 (Decision 2012-297 QPC, 21 February 2013).
} 
confounding effects of the characteristics of the region.

\subsubsection{Pre-Industrial Development}

The differential level of development across France in the pre-industrial era may have affected jointly the subsequent process of development and the process of industrialization. In particular, it may have affected the adoption of the steam engine and it may have generated, independently, a persistent effect on the process of development. Hence, the empirical analysis accounts for the potentially confounding effects of the level of development in the pre-industrial period, more than 150 years prior to the 1860-1865 industrial survey. This early level of development is captured by the degree of urbanization (i.e., population of urban centers with more than 10,000 inhabitants) in each French department in 1700 as well as by the presence of a university in 1700 and $1793 .^{9}$

\section{Empirical Methodology}

\subsection{Empirical Strategy}

The observed relationship between industrialization and economic development is not necessarily indicative of the causal effect of industrialization on economic prosperity. It may reflect the impact of economic development on the process of industrialization as well as the influence of institutional, geographical, cultural and human capital characteristics on the joint evolution of process of development and the onset of industrialization. In light of the endogeneity of industrialization and economic development, this research exploits geographic and climatic sources of regional variation in the diffusion and adoption of steam engines across France to establish the effect of industrialization on the process of development.

The identification strategy consists of two distinct components that govern: (i) the regional diffusion and thus the supply of industrial technologies, and (ii) the differential decline in the profitability of agriculture across regions and thus variations in the pace of industrialization as well as in the demand for industrials technologies.

\subsubsection{The Diffusion of the Steam Engines from Fresnes-sur-Escaut}

The first component of the identification strategy is motivated by the historical account of the gradual regional diffusion of the steam engine in France during the $18^{\text {th }}$ and $19^{\text {th }}$ century (Ballot, 1923; Sée, 1925; Léon, 1976). Considering the positive association between industrialization and the intensity in the use of the steam engine (Mokyr, 1990; Bresnahan and Trajtenberg, 1995; Rosenberg and Trajtenberg, 2004), the study takes advantage of the regional diffusion of the steam engine to identify the effect of local variations in the intensity of the use of the steam engine during the 1860-1865 period on the process of development. In particular, it exploits the distances between each French department and Fresnes-sur-Escaut (in the Nord department), where the first successful commercial and industrial application of the steam engine in France

\footnotetext{
${ }^{9}$ The qualitative analysis remains intact if the potential effect of past population density is accounted for as we show in Section 4.2.2.
} 
was made in 1732, as an instrument for the use of the steam engines in 1860-1865. ${ }^{10}$

Consistent with the diffusion hypothesis, the second steam engine in France that was utilized for commercial purposes was operated in 1737 in the mines of Anzin, also in the Nord department, less than $10 \mathrm{~km}$ away from Fresnes-sur-Escaut. Furthermore, in the subsequent decades till the French Revolution the commercial use of the steam engine expanded predominantly to the nearby northern and north-western regions. Nevertheless, at the onset of the French revolution in 1789, steam engines were less widespread in France than in England. A few additional steam engines were introduced until the fall of the Napoleonic Empire in 1815, notably in Saint-Quentin in 1803 and in Mulhouse in 1812, but it is only after 1815 that the diffusion of steam engines in France accelerated (Sée, 1925; Léon, 1976).

Table 1: The Geographical Diffusion of the Steam Engine

\begin{tabular}{|c|c|c|c|c|c|c|}
\hline & $\begin{array}{l}(1) \\
\text { OLS }\end{array}$ & $\begin{array}{l}(2) \\
\text { OLS }\end{array}$ & $\begin{array}{c}\text { (3) } \\
\text { OLS }\end{array}$ & $\begin{array}{c}(4) \\
\text { OLS }\end{array}$ & $\begin{array}{c}(5) \\
\text { OLS }\end{array}$ & $\begin{array}{c}(6) \\
\text { OLS }\end{array}$ \\
\hline & \multicolumn{6}{|c|}{ Log Horse Power of Steam Engines } \\
\hline Distance to Fresnes & $\begin{array}{c}-0.0052^{* * *} \\
{[0.0009]}\end{array}$ & $\begin{array}{c}-0.0068^{* * *} * \\
{[0.0020]}\end{array}$ & $\begin{array}{c}-0.0092^{* * *} \\
{[0.0025]}\end{array}$ & $\begin{array}{c}-0.0082^{* * *} * \\
{[0.0024]}\end{array}$ & & $\begin{array}{c}-0.013^{* * *} \\
{[0.0028]}\end{array}$ \\
\hline Log Latitude & & $\begin{array}{l}-4.756 \\
{[9.549]}\end{array}$ & $\begin{array}{l}-16.81 \\
{[12.26]}\end{array}$ & $\begin{array}{l}-13.69 \\
{[11.87]}\end{array}$ & $\begin{array}{c}24.59^{* *} \\
{[11.24]}\end{array}$ & $\begin{array}{l}-6.259 \\
{[11.52]}\end{array}$ \\
\hline Log Land Suitability & & $\begin{array}{l}-0.797 \\
{[0.685]}\end{array}$ & $\begin{array}{c}-0.0103 \\
{[0.676]}\end{array}$ & $\begin{array}{c}-0.0825 \\
{[0.709]}\end{array}$ & $\begin{array}{c}0.241 \\
{[0.794]}\end{array}$ & $\begin{array}{l}-0.453 \\
{[0.670]}\end{array}$ \\
\hline Log Average Rainfall & & $\begin{array}{l}-0.0015 \\
{[0.0027]}\end{array}$ & $\begin{array}{l}-0.0001 \\
{[0.0027]}\end{array}$ & $\begin{array}{l}-0.0005 \\
{[0.0027]}\end{array}$ & $\begin{array}{l}-0.0019 \\
{[0.0029]}\end{array}$ & $\begin{array}{l}-0.0014 \\
{[0.0027]}\end{array}$ \\
\hline Log Average Temperature & & $\begin{array}{c}4.240 * * * \\
{[1.402]}\end{array}$ & $\begin{array}{l}2.441^{*} \\
{[1.361]}\end{array}$ & $\begin{array}{l}2.396^{*} \\
{[1.382]}\end{array}$ & $\begin{array}{l}2.161 \\
{[1.482]}\end{array}$ & $\begin{array}{c}3.239^{* *} \\
{[1.409]}\end{array}$ \\
\hline Log Share of Carboniferous Area & & & $\begin{array}{c}1.776 \\
{[1.318]}\end{array}$ & $\begin{array}{l}1.933 \\
{[1.347]}\end{array}$ & $\begin{array}{l}1.515 \\
{[1.392]}\end{array}$ & $\begin{array}{c}1.341 \\
{[1.262]}\end{array}$ \\
\hline Rivers and Tributaries & & & $\begin{array}{c}0.861^{* *} \\
{[0.334]}\end{array}$ & $\begin{array}{c}0.765^{* *} \\
{[0.341]}\end{array}$ & $\begin{array}{c}0.904^{* *} \\
{[0.349]}\end{array}$ & $\begin{array}{c}0.677^{* * *} \\
{[0.336]}\end{array}$ \\
\hline Paris and Suburbs & & & $\begin{array}{l}-0.199 \\
{[0.722]}\end{array}$ & $\begin{array}{l}-0.317 \\
0.518]\end{array}$ & $\begin{array}{c}0.111 \\
{[0.553]}\end{array}$ & $\begin{array}{c}0.533 \\
{[0.574]}\end{array}$ \\
\hline Alsace-Lorraine & & & $\begin{array}{c}2.128^{* * * *} \\
{[0.630]}\end{array}$ & $\begin{array}{c}1.862^{* *} \\
{[0.733]}\end{array}$ & $\begin{array}{c}1.197 \\
{[0.999]}\end{array}$ & $\begin{array}{l}1.057 \\
{[0.834]}\end{array}$ \\
\hline Maritime Department & & & $\begin{array}{c}1.161^{* * *} \\
{[0.400]}\end{array}$ & $\begin{array}{c}0.939^{* *} \\
{[0.386]}\end{array}$ & $\begin{array}{l}0.266 \\
{[0.459]}\end{array}$ & $\begin{array}{l}0.370 \\
{[0.446]}\end{array}$ \\
\hline Border Department & & & $\begin{array}{l}-0.303 \\
{[0.440]}\end{array}$ & $\begin{array}{l}-0.184 \\
{[0.451]}\end{array}$ & $\begin{array}{l}-0.113 \\
{[0.534]}\end{array}$ & $\begin{array}{l}-0.775 \\
{[0.535]}\end{array}$ \\
\hline Log Urban Population in 1700 & & & & $\begin{array}{c}0.163 \\
{[0.103]}\end{array}$ & $\begin{array}{c}0.226^{* *} \\
{[0.107]}\end{array}$ & $\begin{array}{c}0.170 \\
{[0.103]}\end{array}$ \\
\hline Distance to Paris & & & & & $\begin{array}{c}0.0012 \\
{[0.0027]}\end{array}$ & $\begin{array}{c}0.0089^{* * *} * \\
{[0.0029]}\end{array}$ \\
\hline Adjusted R2 & 0.326 & 0.387 & 0.456 & 0.465 & 0.419 & 0.495 \\
\hline Observations & 89 & 89 & 89 & 89 & 89 & 89 \\
\hline
\end{tabular}

Notes: This table presents the results of OLS regression analysis of the geographical diffusion of the steam engine across departments in France, as captured by the negative association between the log number of horse power of steam engines used in the department in 1860-1865 and the distance of the department (in kilometers) from the location of the first commercial use of the steam engine in France - Fresnes-sur-Escaut. The regressions accounts for a range of geographical, institutional, and pre-industrial characteristic. All regressions include a dummy variable for the three departments which had no steam engine in 1860-1865. Heteroskedasticity-robust standard errors are reported in brackets. ${ }^{* * *}$ denotes statistical significance at the $1 \%$-level, $* *$ at the $5 \%$-level, $*$ at the $10 \%$-level, for two-sided hypothesis tests.

Indeed, in line with the historical account, the unequal distribution of steam engines across French departments, as reported in the 1860-1865 industrial survey, is indicative of a local diffusion process from Fresnes-sur-Escaut. As reported in Column 1 of Table 1, there is a highly significant negative correlation between the aerial distance from Fresnes-sur-Escaut to the administrative center of each department and the intensity of the use of steam engines in the department. Nevertheless, as discussed in Section 2.3, preindustrial development and a wide range of confounding geographical and institutional characteristics may

\footnotetext{
${ }^{10}$ This steam engine was used to pump water in an ordinary mine of Fresnes-sur-Escaut. It is unclear whether Pierre Mathieu, the owner of the mine, built the engine himself after a trip in England or employed an Englishman for this purpose (Ballot, 1923, p.385)
} 
have contributed to the adoption of the steam engine. Reassuringly, the unconditional negative relationship remains highly significant and is larger in absolute value when exogenous confounding geographical controls (i.e., land suitability, latitude, rainfall and temperature) (Column 2), as well as institutional factors (Column 3) and pre-industrial development (Column 4), are accounted for. In particular, the findings suggest that pre-industrial development, as captured by the degree of urbanization in each department in 1700 and the characteristics that may have brought this early prosperity, had a persistent positive and significant association with the adoption of the steam engine. ${ }^{11}$ Importantly, the diffusion pattern of steam engines is not significantly correlated with the distance between Paris and the administrative center of each department when the distance from Fresnes to each department's administrative center is excluded from the analysis (Column 5). Moreover, Column 6 of Table 1 and Figure 4 indicate that, when the distance to Paris is accounted for, there is still a highly significant negative correlation between the distance from Fresnes-surEscaut to the administrative center of each department and the intensity of the use of steam engines in the department.

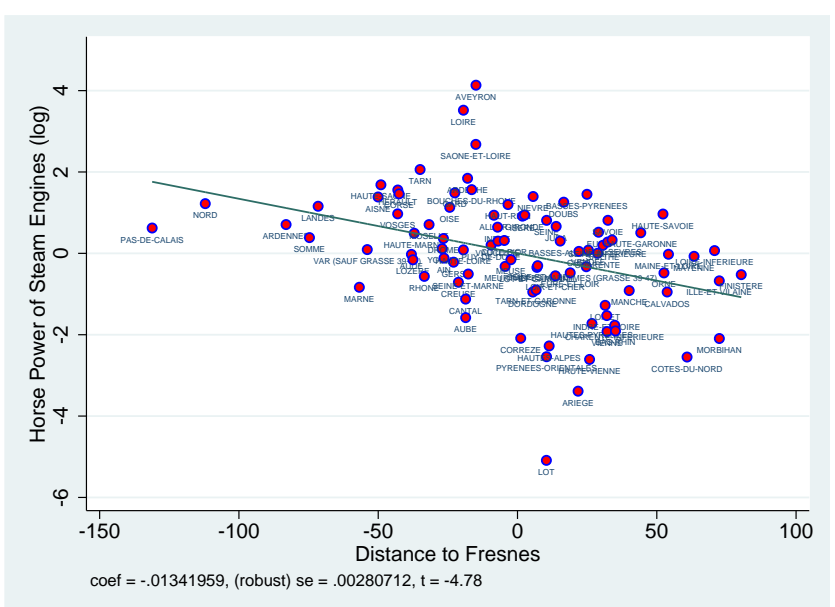

Figure 4: The geographical diffusion of the steam engine - the negative relationship between the distance from Fresnes-surEscaut and the intensity in the use of the steam engine.

Notes: This figure depicts the partial conditional regression line of the association between distance from Fresnes-sur-Escaut and the horse power in steam engines in each French department in 1860-1865, accounting for geographic and institutional characteristics, as well as for pre-industrial development.

The validity of the aerial distance from Fresnes-sur-Escaut as an instrumental variable for the intensity of the adoption of steam engines across France is enhanced by third additional factors. First, Table 2 establishes that, conditional on the distance from Fresnes-sur-Escaut, distances between each department and major centers of economic power in 1860-1865 are uncorrelated with the intensive use of the steam engine over this period. In particular, conditional on the distance from Fresnes-sur-Escaut, distances between each department and Marseille and Lyon (the largest cities in France after Paris), Rouen (a major harbor in the north-west where the steam engine was introduced in 1796), Mulhouse (a major city in the east where the

\footnotetext{
${ }^{11}$ Conceivably, human capital in the pre-industrial area could have affected the adoption of the steam engine, as well as the subsequent process of development. Nevertheless, in light of the scarcity of data on reliable human capital for the pre-industrial period, the baseline analysis does not account for this confounding factor. Instead, Section 4.2.3 shows the robustness of the results to the inclusion of pre-industrial levels of human capital for a smaller set of departments.
} 
steam engine was introduced in 1812), and Bordeaux (a major harbor in the south-west) are uncorrelated with the adoption of the steam engine, lending credence to the unique role of Fresnes-sur-Escaut and the introduction of the first steam engine in this location in the diffusion of the steam engine across France. ${ }^{12}$ Table 2 further establishes that conditional on the distance from Fresnes-sur-Escaut, distances between each department and London and Berlin (i.e., the capitals of England and Germany which were the other two largest industrial economies in Europe in the 19th century) are uncorrelated with the use of the steam engine within France.

Table 2: The Diffusion of the Steam Engine: Accounting for Distances from Major Cities

\begin{tabular}{|c|c|c|c|c|c|c|c|c|}
\hline & $\begin{array}{l}(1) \\
\text { OLS }\end{array}$ & $\begin{array}{l}(2) \\
\text { OLS }\end{array}$ & $\begin{array}{l}(3) \\
\text { OLS }\end{array}$ & $\begin{array}{c}(4) \\
\text { OLS }\end{array}$ & $\begin{array}{c}\text { (5) } \\
\text { OLS }\end{array}$ & $\begin{array}{c}(6) \\
\text { OLS }\end{array}$ & $\begin{array}{l}(7) \\
\text { OLS }\end{array}$ & $\begin{array}{c}(8) \\
\text { OLS }\end{array}$ \\
\hline & \multicolumn{8}{|c|}{ Log Horse Power of Steam Engines } \\
\hline Distance to Fresnes & $\begin{array}{c}-0.0052^{* * *} \\
{[0.00085]}\end{array}$ & $\begin{array}{c}-0.0059^{* * *} \\
{[0.0011]}\end{array}$ & $\begin{array}{c}-0.0053^{* * *} \\
{[0.00089]}\end{array}$ & $\begin{array}{c}-0.0073^{* * *} \\
{[0.0013]}\end{array}$ & $\begin{array}{c}-0.0047^{* * * *} \\
{[0.00097]}\end{array}$ & $\begin{array}{c}-0.0045^{* * *} \\
{[0.00098]}\end{array}$ & $\begin{array}{c}-0.0065^{* * *} \\
{[0.0012]}\end{array}$ & $\begin{array}{c}-0.0038^{* * *} \\
{[0.0014]}\end{array}$ \\
\hline Distance to Marseille & & $\begin{array}{l}-0.0010 \\
{[0.0012]}\end{array}$ & & & & & & \\
\hline Distance to Lyon & & & $\begin{array}{l}-0.0008 \\
{[0.0012]}\end{array}$ & & & & & \\
\hline Distance to Rouen & & & & $\begin{array}{c}0.0024 \\
{[0.0015]}\end{array}$ & & & & \\
\hline Distance to Mulhouse & & & & & $\begin{array}{c}-0.0012 \\
{[0.00094]}\end{array}$ & & & \\
\hline Distance to Bordeaux & & & & & & $\begin{array}{c}0.0019 \\
{[0.0012]}\end{array}$ & & \\
\hline Distance to London & & & & & & & $\begin{array}{c}0.0014 \\
{[0.0012]}\end{array}$ & \\
\hline Distance to Berlin & & & & & & & & $\begin{array}{l}-0.0019 \\
{[0.0013]}\end{array}$ \\
\hline Adjusted R2 & 0.326 & 0.324 & 0.322 & 0.331 & 0.328 & 0.339 & 0.324 & 0.332 \\
\hline Observations & 89 & 89 & 89 & 89 & 89 & 89 & 89 & 89 \\
\hline
\end{tabular}

Notes: This table establishes that the negative association between the log number of horse power of steam engines used in the department in $1860-1865$ and the distance of the department (in kilometers) from the location of the first commercial use of the steam engine in France - Fresnes-sur-Escaut, is unaffected by distances from other major cities in France the capital of England and Germany. All regressions include a dummy variable for the three departments which had no steam engine in 1860-1865. Heteroskedasticity-robust standard errors are reported in brackets. *** denotes statistical significance at the $1 \%$-level, ** at the $5 \%$-level, * at the $10 \%$-level, for two-sided hypothesis tests.

Second, the distance from Fresnes-sur-Escaut is uncorrelated with economic development across France in the pre-industrial period. Unlike the highly significant negative relationship between the distance from Fresnes-sur-Escaut and the intensity of the use of the steam engine in 1860-1865, Table 3 and Figure 5 establish that the distance from Fresnes-sur-Escaut was uncorrelated with urban development and human capital formation in the pre-industrial era. In particular, Column 1 in Table 3 shows that urbanization rates in 1700 are uncorrelated with the distance from Fresnes-sur-Escaut. Column 4 establishes that literacy rates in the pre-industrial period, as captured by the share of grooms who could sign their marriage license in 1686-1690, are uncorrelated with the distance from Fresnes-sur-Escaut. Finally, Column 7 demonstrates that there is no significant relationship between the presence of a university in 1700 and the distance from Fresnes-sur-Escaut. ${ }^{13}$ Moreover, Table 3 and Figure 5 establish that the distance to Fresnes is not a predictor of development in the 18th century, as captured by urbanization rates in 1780 and changes in urbanization between 1700 and 1780 (Columns 2 and 3), literacy in 1786-1790 and changes in literacy between 1686-90

\footnotetext{
${ }^{12}$ As reported in Table B.1, the use of an alternative measure of distances based on the time needed for a surface travel between any pair of locations (Özak, 2010) does not affect the qualitative results.

${ }^{13}$ It should be noted that these pre-industrial measures of development are highly correlated with income per-capita in the post-industrialized period. For instance, the urban population in 1700 is positively correlated with all our measures of GDP per capita in 1860 (0.570), 1901 (0.293), 1930 (0.551) and 2001-2005 (0.517).
} 
and 1786-90 (Columns 5 and 6) as well as the presence of an university in the department in 1793 and the change in the presence of an university between 1700 and 1793 (Columns 8 and 9).

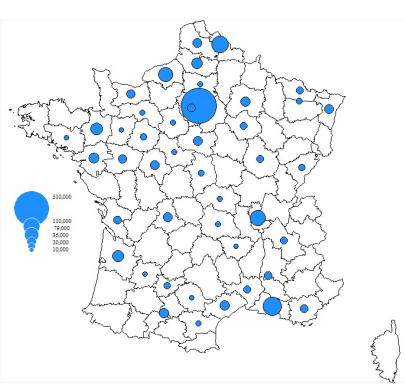

A. Urban population in 1700

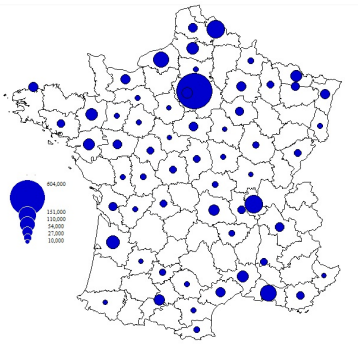

D. Urban population in 1780

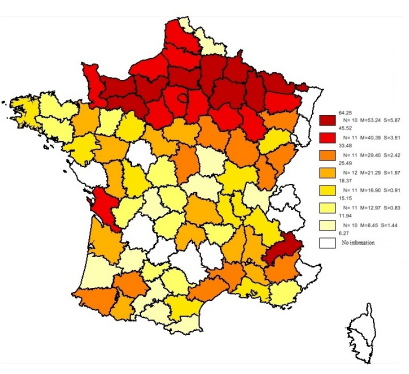

B. Literacy rates in $1686-1690$

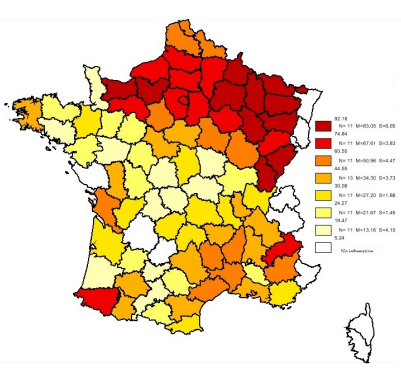

E. Literacy rates in $1786-1790$

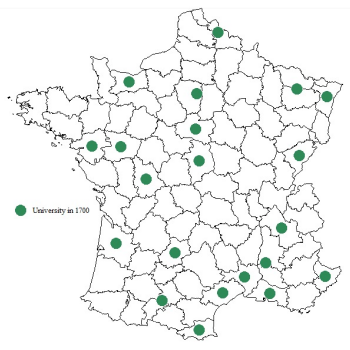

C. Universities in 1700 .

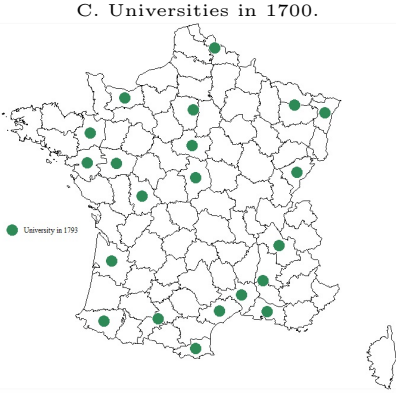

F. Universities in 1793 .

Figure 5: Pre-industrial characteristics of French departments

Note: In Panel B, literacy in 1686-1690 is captured by the share of grooms who signed their marriage license during that period.

Table 3: Orthogonality of Pre-Industrial Development to the Distance from Fresnes-sur-Escaut

\begin{tabular}{|c|c|c|c|c|c|c|c|c|c|}
\hline & $\begin{array}{c}(1) \\
\text { Tobit }\end{array}$ & $\begin{array}{c}(2) \\
\text { Tobit }\end{array}$ & $\begin{array}{l}(3) \\
\text { OLS }\end{array}$ & $\begin{array}{l}(4) \\
\text { OLS }\end{array}$ & $\begin{array}{c}(5) \\
\text { OLS }\end{array}$ & $\begin{array}{l}(6) \\
\text { OLS }\end{array}$ & $\begin{array}{l}(7) \\
\text { OLS }\end{array}$ & $\begin{array}{c}\text { (8) } \\
\text { OLS }\end{array}$ & $\begin{array}{l}(9) \\
\text { OLS }\end{array}$ \\
\hline & \multicolumn{3}{|c|}{ Urban Population } & \multicolumn{3}{|c|}{ Literacy } & \multicolumn{3}{|c|}{ University } \\
\hline & $\begin{array}{l}\text { Level } \\
1700\end{array}$ & $\begin{array}{l}\text { Level } \\
1780\end{array}$ & $\begin{array}{l}\text { Change } \\
1700-80\end{array}$ & $\begin{array}{c}\text { Level } \\
1686-90\end{array}$ & $\begin{array}{c}\text { Level } \\
1786-90\end{array}$ & $\begin{array}{c}\text { Change } \\
1686-90 / 1786-90\end{array}$ & $\begin{array}{c}\text { Level } \\
1700\end{array}$ & $\begin{array}{l}\text { Level } \\
1793\end{array}$ & $\begin{array}{l}\text { Change } \\
1700-93\end{array}$ \\
\hline Distance to Fresnes & $\begin{array}{c}-0.010 \\
{[0.0062]}\end{array}$ & $\begin{array}{c}-0.004 \\
{[0.0048]}\end{array}$ & $\begin{array}{c}0.003 \\
{[0.0027]}\end{array}$ & $\begin{array}{c}-0.020 \\
{[0.0409]}\end{array}$ & $\begin{array}{c}-0.098 \\
{[0.0602]}\end{array}$ & $\begin{array}{c}-0.004 \\
{[0.0025]}\end{array}$ & $\begin{array}{c}0.001 \\
{[0.0009]}\end{array}$ & $\begin{array}{c}0.001 \\
{[0.0009]}\end{array}$ & $\begin{array}{c}0.0003 \\
{[0.0006]}\end{array}$ \\
\hline Geographic characteristics & Yes & Yes & Yes & Yes & Yes & Yes & Yes & Yes & Yes \\
\hline Institutional characteristics & Yes & Yes & Yes & Yes & Yes & Yes & Yes & Yes & Yes \\
\hline Pseudo R2 & 0.095 & 0.090 & & & & & & & \\
\hline Adjusted R2 & & & 0.021 & 0.493 & 0.494 & 0.242 & 0.161 & 0.177 & -0.076 \\
\hline Observations & 89 & 89 & 89 & 76 & 79 & 76 & 89 & 89 & 89 \\
\hline
\end{tabular}

Notes: This table establishes the orthogonality of the distance from the location of the first commercial use of the steam engine in France (Fresnes-sur-Escaut) to three measures of the level and the change in pre-industrial development (i.e., urban population in 1700,1780 and its growth between these periods; literacy rate in 1686-90, 1786-90 and its growth between these periods; the probability of presence of a university in 1700 , 1793 , and the change in this probability over this period). Geographic characteristics include the department's latitude, land suitability, average rainfall and temperature, share of carboniferous area, distance to Paris and dummies for the presence of rivers and tributaries, maritime and border departments. Institutional measures include dummies for Alsace-Lorraine and for Paris and its suburbs. Heteroskedasticity-robust standard errors are reported in brackets. *** denotes statistical significance at the $1 \%$-level, ** at the $5 \%$-level, * at the $10 \%$-level, for two-sided hypothesis tests.

Third, it appears that the Nord department had neither superior human capital characteristics nor higher standard of living in comparison to the average department in France. An imperfect measure of literacy 
(i.e., grooms who could sign their wedding contract over the 1686-1690 period) prior to the introduction of the first steam engine in 1732, suggests that if anything, Nord's literacy rate was below the French average. Specifically, only $10.45 \%$ of men in Nord could sign their wedding contract over the 1686-1690 period while the average for the rest of France was 26.10\% (with a standard deviation of 14.86\%) (Furet and Ozouf, 1977). Furthermore, using height as an indicator for the standard of living suggests that the standard living in Flanders, the province of the French kingdom prior to 1789 which contained Fresnes-sur-Escaut, was nearly identical to that of the rest of France (Komlos, 2005). ${ }^{14}$ As depicted in Figure G.2 in the Appendix, variations in the average height of French army soldiers from Flanders over the 1700-65 period were not different from those of the soldiers from other parts of France.

\subsubsection{Temperature Shocks and the Transition from Agriculture to Industry}

The second component of the identification strategy exploits regional variations in temperature deviations (on the eve of the industrial survey) from their historical trend to capture exogenous sources of variation in the profitability of agriculture and therefore in the pace of industrialization and the demand for steam engine technologies across departments. In particular, in order to capture the changes in the profitability of agriculture production in the eve of the 1860-1865 industrial survey on the adoption of steam engines across departments, the analysis exploits regional variations in the squared deviations of fall temperatures in the 1856-1859 period from the average fall temperature, over the earlier 25-year period (1831-1855). ${ }^{15}$ Temporary temperature deviations and their adverse effect on the supply and the stock of crops have a significant positive effect on the prices of the dominating crops in the subsequent years, but no longer on the productivity in the agricultural sector, and they diminish therefore the disincentive to reallocate resources from the agricultural to the industrial sector.

Let $\tilde{T}_{i, 1856-1859,(25)}$ be the squared deviation of fall temperatures in the 1856-1859 period in department i from its average fall temperatures over the preceding 25-year period, 1831-1855.

$$
\tilde{T}_{i, 1856-1859,(25)} \equiv\left[\mu_{i, 1856-1859}-\mu_{i, 1831-1855}\right]^{2}
$$

where $\mu_{i, 1856-1859}$ is the average fall temperature over the 1856-1859 period and $\mu_{i, 1831-1855}$ is the average fall temperature in the 1831-1855 baseline period.

Panel A of Figure 6 displays the average fall temperature in 1856-1859 across the French departments while Panel B of Figure 6 depicts the squared deviation in average fall temperature in the 1856-1859 period, using $1831-1855$ as the baseline period, i.e., the $\tilde{T}_{i, 1856-1859,(25)}$ variable.

\footnotetext{
${ }^{14}$ Concerns regarding selection bias suggest that the height of soldiers may not always be representative of the height of the general population (see, e.g., Baten, 2000) but there is no reason to think that this selection bias would be more or less intense in Flanders than in the rest of France.

${ }^{15}$ Unlike temperature deviations over the fall season, as established in Table B.3, temperature deviations in other seasons, as well as rainfall deviations in the fall (and other seasons), do not have a significant effect on the adoption of steam engines. Spring wheat - the dominant crop in France over this period - was harvested in late summer and early fall, and its grains that were stored for planting in the spring were particularly sensitive to high temperature in the fall that affected their ability to germinate over time. The harvest of wine grapes -the second dominating crop - took place over the entire fall season and was directly sensitive to temperature during this season. Finally, other important crops, barely, oat, and corn, completed their harvest in the early part of the fall and the deprecation of their stored grains was sensitive to the fall temperature as well.
} 


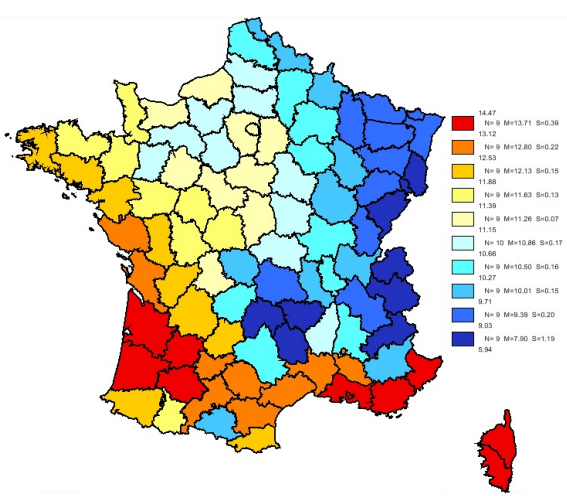

A. Average Temperature in Fall 1856-1859

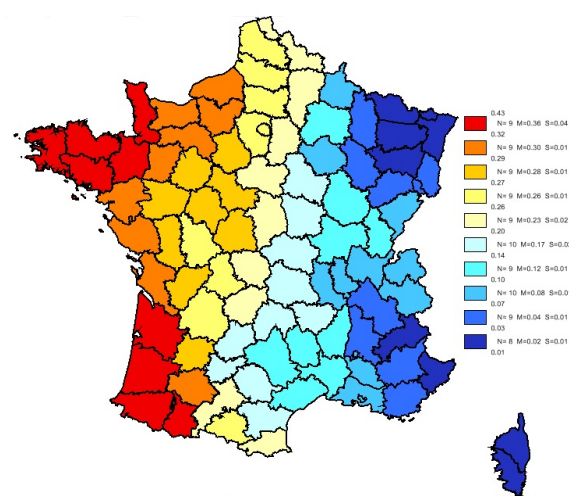

B. Squared Deviation from Average Fall Temperature in 1856-59 (Baseline 1831-55)

Figure 6: Average Temperature in Fall 1856-1859 and their Deviation from Historical Trend

Table 4: Temperature shocks and the adoption of the steam engine

\begin{tabular}{|c|c|c|c|c|c|c|}
\hline & $\begin{array}{l}\text { (1) } \\
\text { OLS }\end{array}$ & $\begin{array}{l}\text { (2) } \\
\text { OLS }\end{array}$ & $\begin{array}{l}(3) \\
\text { OLS }\end{array}$ & $\begin{array}{l}(4) \\
\text { OLS }\end{array}$ & $\begin{array}{c}(5) \\
\text { OLS }\end{array}$ & $\begin{array}{l}(6) \\
\text { OLS }\end{array}$ \\
\hline & \multicolumn{6}{|c|}{ Log Horse Power of Steam Engines } \\
\hline Distance to Fresnes & & & & $\begin{array}{c}-0.0073^{* * *} \\
{[0.0026]}\end{array}$ & $\begin{array}{c}-0.0087^{* * *} \\
{[0.0024]}\end{array}$ & $\begin{array}{c}-0.0069^{* *} \\
{[0.0028]}\end{array}$ \\
\hline $\begin{array}{l}\text { Temperature Deviations (1856-1859) } \\
\text { (Baseline Fall 1831-1855) }\end{array}$ & $\begin{array}{c}-6.782^{* * *} \\
{[1.651]}\end{array}$ & & & $\begin{array}{c}-4.484^{* *} \\
{[1.995]}\end{array}$ & & \\
\hline $\begin{array}{l}\text { Temperature Deviations (1856-1859) } \\
\quad \text { (Baseline Fall 1841-1855) }\end{array}$ & & $\begin{array}{c}-6.418^{* * *} \\
{[1.787]}\end{array}$ & & & $\begin{array}{l}-3.828^{*} \\
{[2.012]}\end{array}$ & \\
\hline $\begin{array}{l}\text { Temperature Deviations (1856-1859) } \\
\text { (Baseline Fall 1806-1855) }\end{array}$ & & & $\begin{array}{c}-13.73^{* * *} \\
{[3.300]} \\
\end{array}$ & & & $\begin{array}{c}-8.883^{* *} \\
{[4.332]}\end{array}$ \\
\hline Geographic characteristics & Yes & Yes & Yes & Yes & Yes & Yes \\
\hline Institutional characteristics & Yes & Yes & Yes & Yes & Yes & Yes \\
\hline Pre-industrial development & Yes & Yes & Yes & Yes & Yes & Yes \\
\hline Adjusted R2 & 0.638 & 0.623 & 0.638 & 0.649 & 0.643 & 0.646 \\
\hline Observations & 89 & 89 & 89 & 89 & 89 & 89 \\
\hline
\end{tabular}

Note: This table establishes the first stage of our estimation strategy where we relate the log of the horse power of steam engines to the distance from Fresnes-sur-Escaut and temperature deviations over the 1856-1859 period. The relationship is shown to be robust to three baseline periods, i.e, 1831-1855, 1841-1855 and 1806-1855. The dependent variable is in logarithm. Geographic characteristics include the department's latitude, land suitability, average rainfall and temperature, share of carboniferous area, distance to Paris as well as dummies for the presence of rivers and tributaries, maritime and border departments. Institutional measures include dummies for Alsace-Lorraine and for Paris and its suburbs. Pre-industrial development characteristics include a measure of the urban population in 1700 . Heteroskedasticity-robust standard errors are reported in brackets. *** indicates significance at the $1 \%-l e v e l, * *$ at the $5 \%$-level, * at the $10 \%$-level.

Table 4 suggests that, accounting for geographic and institutional characteristics, the horse power of steam engines across French departments in 1860-1865 is negatively associated with the squared deviation in fall temperature in 1856-1859 period, where the historical trend is computed over the 1831-1855 period (Column (1), and as shown in Figure 7), the 1841-1855 period (Column (2)) and the 1806-1855 period (Column (3)). Moreover, this negative association remains significant once we account for the Distance from Fresnes (Columns (4)-(6)). ${ }^{16}$

\footnotetext{
${ }^{16}$ Even though it appears from the spatial distribution of the two instrumental variables that they depict some north-east
} 


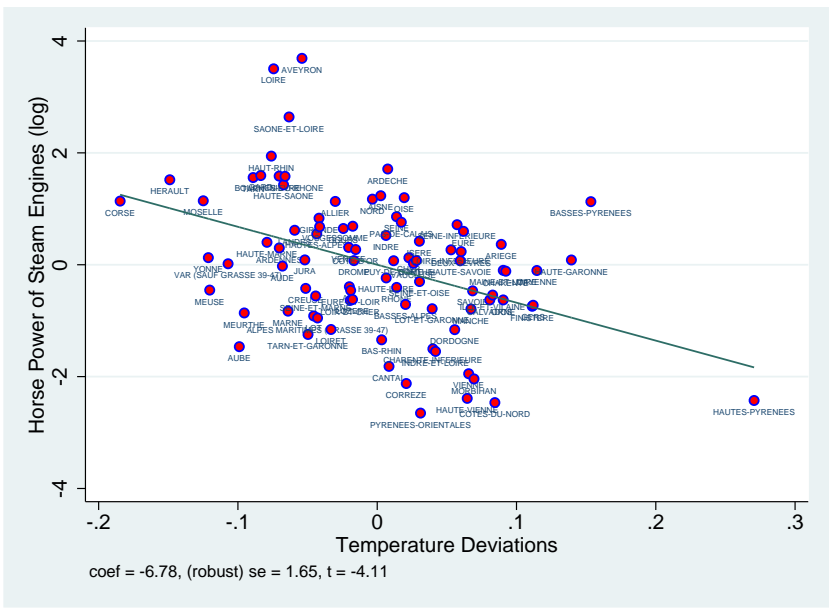

Figure 7: Temperature deviations and the intensity in the use of the steam engine.

Notes: This figure depicts the partial unconditional regression line of the association between temperature deviations over the $1856-1859$ on the 1831-1855 baseline and the horse power in steam engines in each French department in 1860-1865.

Tables B.3 and B.4 in the Appendix provide falsification tests in support of the causal impact of the squared deviation of fall temperature in 1856-1859 period from the 1831-1855 baseline period. Table B.3 shows that temperature deviations in the spring, summer and winter of 1856-1859 do not have a significant impact of the adoption of steam engines in 1860-1865 beyond the one captured by temperature deviations in the fall. It also shows that the squared deviation of rainfall in fall 1856-1859 has no impact. More importantly, Table B.4 shows that temperature deviations in other time intervals before the 1860-1865 industrial survey (i.e., 1844-1847, 1848-1851 and 1852-1855) or afterwards (i.e., 1866-1869 and 1870-1873) are not correlated with the horse power of steam engines in 1860-1865.

Since temperature deviations from their historical trend are likely to be associated with reductions in crop yields, and consequently higher crop prices, temperature deviations are likely to delay the transition to industry. Indeed, Table B.5 in the Appendix demonstrates that the effect of temperature deviations on steam engine adoption is operating through the profitability of agricultural production as captured by wheat prices. Columns (1) and (2) establish that average temperature deviations in the fall of 1856-1859 are associated with higher wheat prices in the fall of 1856-1859, relative to the 1831-1855 baseline level. Column (4) suggests that higher wheat prices are indeed associated with a lesser adoption of the steam engine and Column (5) demonstrates that the effect of temperature deviations on the adoption of steam engines is partly mediated through the rise in wheat prices. Temperature deviations in the fall are also highly correlated with wheat prices in the year as a whole as shown in Table B.6. ${ }^{17}$ Nevertheless, since planting decisions are likely to be based on wheat prices during the harvest period in the fall, the adverse effect of wheat prices in the fall

to south west orientation, the correlation coefficient between the two instruments is low and equal to -0.0183 and the OLS regression in Column (1) of Table B.2 of Distance to Fresnes on Temperature Deviations provides a negative and insignificant coefficient. Furthermore, if one nets out a possible common orientation of the two instruments, and uses the residual from regression one instrument over the other as an instrumental variable, as established in Table B.2, the results are even stronger economically and statistically.

${ }^{17}$ Supplementary regressions show that wheat prices in each individual month of September, October and November are also correlated with temperature deviations in the fall. However these monthly wheat prices have no significant effect on the adoption of steam engines. 
on the transition to industry is more pronounced when wheat prices in the fall are considered. Furthermore, while temperature deviations have a significant impact on wheat prices in 1856-1859, Table B.7 establishes that, conditional on temperature deviations in the fall, rainfall deviations in any of the four seasons do not have a significant association with wheat prices over this time period. ${ }^{18}$

Interestingly, while temperature deviations in the period that preceded the 1856-1859 period had no effect on the intensity of industrialization in 1860-1865, Table B.8 establishes that temperature deviations in the 1856-1859 period and their impact on the horse power of steam engines in 1860-1865 had generated a technological head-start in these departments that persisted over time. Namely, as demonstrated in Column (1), temperatures deviations in 1856-1859 and their positive impact on the incentives to remain in the agricultural sector, are negatively and significantly associated with the horse power of steam engines in the later industrial survey of 1897. However, as demonstrated in Column (2), this adverse effect operates through the persistent effect of the intensity of industrialization in each department in 1860-1865, rather than the lingering effect of past tempreture deviations on crop prices decades later.

\subsubsection{Determinants of the Adoption of the Steam Engine}

Accounting for the confounding effects of geographical, institutional and pre-industrial characteristics, Column (4) in Table 4 reports the significant negative relationship between the horse power of steam engines and the instrumental variables: (i) the distance from Fresnes and (ii) the squared deviation of fall temperatures in the 1856-1859 period from their historical trend over the 1831-1855 period. In particular, Column (4) of Table 4 shows that accounting for confounding geographical and institutional characteristics, pre-industrial development, distances from major economic centers as well as temperature deviations from their historical trend, a 100-km increase in the distance from Fresnes-sur-Escaut is associated with a 0.73 decrease in the $\log$ of horse power of steam engines in a department. unit increase in the squared deviation of temperatures in the period 1856-1859 from the average temperature over the 1831-1855 period is associated with a 4.48-point decrease in the log of horse power of steam engines in a department. In particular, if the distance of a department away from Fresnes-sur-Escaut was to increase from the 40th $(426 \mathrm{~km})$ to the 60th percentile $(559 \mathrm{~km})$ of the distance distribution, this department would experience an aggregate drop of 275 in the horse power of steam engines (relative to a sample mean of $1839.35 \mathrm{hp}$ ).

Moreover, regional variations in temperature deviations from their historical trend is associated with regional variation in the profitability of agriculture (as reflected by wheat prices), and in the adoption of steam engines. In particular, conditional on the distance from Fresnes-sur-Escaut, a one-unit increase in the squared deviation of temperatures in the period 1856-1859 from the average temperature over the 1831-1855 period is associated with a 4.48-point decrease in the log of horse power of steam engines in a department. As such, in comparison to a department at the 40th percentile of the squared temperature deviation (i.e., 0.14), a department with a 60th percentile of the squared temperature deviation (i.e., 0.25), will be expected to experience a drop of 13.9 in the horse power of steam engines.

These estimated effects suggest that the diffusion of the steam engine as well the transition from agriculture to industry contributed to the adoption of steams engines. Nevertheless, the qualitative results

\footnotetext{
${ }^{18}$ It should be noted that rainfall deviations in each season have no significant effect on the adoption of steam engines, accounting for the instruments Distance to Fresnes and Temperature Deviations.
} 
remain unchanged if either one of the two instruments are used separately as shown by Tables B.9 and B.10 in the Appendix.

Finally, the highly significant negative effect of (i) the distance from Fresnes-sur-Escaut to the administrative center of each department and of (ii) the deviation of fall temperature in 1856-1859 from their baseline level on the horse power of steam engines in each department in 1860-1865 is robust to the inclusion of an additional set of confounding geographical, demographic and institutional characteristics, as well as to the forces of pre-industrial development, which as discussed in section 4.2, may have contributed to the relationship between industrialization and economic development. As established in Table B.11 in the Appendix, these confounding factors, which could be largely viewed as endogenous to the adoption of the steam engine and are thus not considered as part of the baseline analysis, do not affect the qualitative results.

\subsection{Empirical Model}

The effect of early industrialization on the entire subsequent process of development is estimated using 2SLS. The second stage provides a cross-section estimate of the relationship between the total horse power of steam engines in each department in 1860-1865 to measures of income per capita, human capital formation and other economic outcomes at different points in time;

$$
Y_{i t}=\alpha+\beta E_{i}+\boldsymbol{X}_{\boldsymbol{i}}^{\prime} \omega+\varepsilon_{i t}
$$

where $Y_{i t}$ represents one measure of economic outcomes in department $i$ in year $t, E_{i}$ is the $\log$ of total horse power of steam engines in department $i$ in 1860-1865, $\boldsymbol{X}_{\boldsymbol{i}}^{\prime}$ is a vector of geographical, institutional and pre-industrial economic characteristics of department $i$ and $\epsilon_{i t}$ is an i.i.d. error term for department $i$ in year $t .^{19}$

In the first stage, $E_{i}$, the log of total horse power of steam engines in department $i$ in 1860-1865 is instrumented by $D_{i}$, the aerial distance (in kilometers) between the administrative center of department $i$ and Fresnes-sur-Escaut, as well as by $\tilde{T}_{i, 1856-1859,(25)}$, the squared deviation of fall temperatures in the 1856-1859 period in department i from the average fall temperatures over the preceding 25-year period, 1831-1855;

$$
E_{i}=\delta_{1} D_{i}+\delta_{2} \tilde{T}_{i, 1856-1859,(25)}+\boldsymbol{X}_{\boldsymbol{i}}^{\prime} \delta_{3}+\mu_{i},
$$

where $\boldsymbol{X}_{\boldsymbol{i}}^{\prime}$ is the same vector of geographical, institutional and pre-industrial economic characteristics of department $i$ used in the second stage, and $\mu_{i}$ is an error term for department $i$.

\section{Industrialization and the Evolution of the Standard of Living}

\subsection{Industrialization and the Dynamics of Income per Capita}

The study examines the effect of the intensity in the use of steam engines in the 1860-1865 period on the evolution of income per capita in the process of development. As established in Tables 5 and 6 , and

\footnotetext{
${ }^{19}$ The early industrial survey of $1839-1847$ is not comparable to the $1860-1865$ survey since it does not account for the horse power of steam engine.
} 
depicted in Figure 8, consistently with the proposed hypothesis, industrialization was conducive for economic development in the short-run and in the medium-run but had a detrimental effect on standards of living in the long-run. ${ }^{20}$ In particular, the horse power of steam engines in industrial production in the 1860-1865 period had a positive and significant impact on income per capita in 1860, 1901 and 1930 but a negative and significant effect on income per capita during the 2001-2005 period.

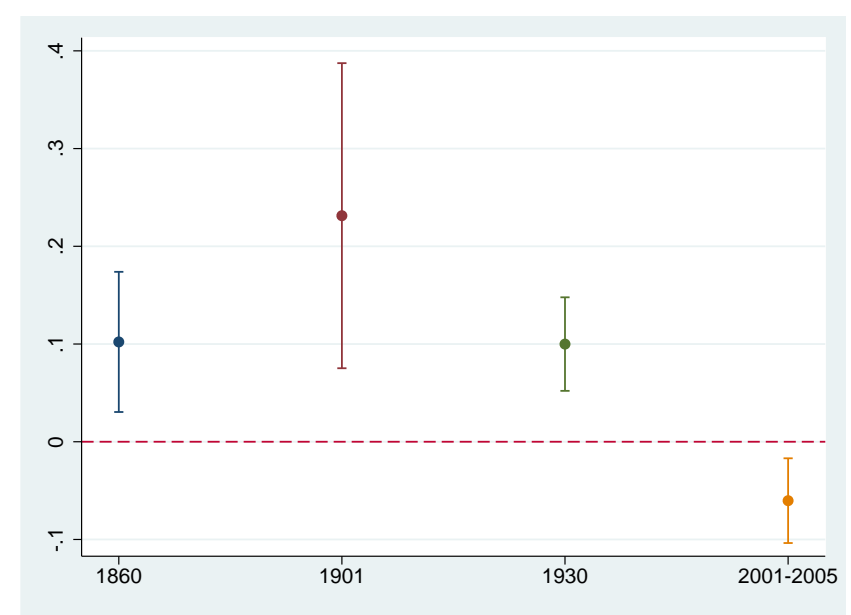

Figure 8: The effect of the horse power of steam engines in 1860-1865 on GDP per capita Note: This figure displays the estimated coefficients of Horse Power of Steam Engines in the IV regressions in Columns 5 and 10 of Tables 5 and 6 . Intervals reflect $95 \%$-confidence levels.

The relationship between industrialization and income per capita in the short-run and in the mediumrun is presented in Table 5 and in the first five Columns of Table 6. As shown in Columns (1) and (6) in Table 5 and in Column (1) in Table 6, unconditionally, the horse power of steam engines in industrial production in the 1860-1865 period had a highly significant positive association with income per capita in 1860, 1901 and 1930. Moreover, this relationship remains positive, although somewhat smaller and less significant, once one progressively accounts for the confounding effects of exogenous geographical factors (Columns (2) and (7) in Table 5 and Column (2) in Table 6), institutional factors (Columns (3) and (8) in Table 5 and Column (3) in Table 6) and pre-industrial characteristics (Columns (4) and (9) in Table 5 and Column (4) in Table 6). Finally, mitigating the effect of omitted variables on the observed relationship, the IV estimation in Columns (5), (10) and (11) in Table 5 suggests that the horse power of steam engines in 1860-1865 had a positive and significant impact on income per capita in 1860 and 1901, accounting for the confounding effects of geographical, institutional, and demographic characteristics. We also note that the effect of industrialization in 1860-1865 on log GDP per capita in 1930 is still positive and significant in Column (5) of Table 6 but that this effect is not significant anymore (although still positive) when we include log GDP per capita in 1860 as an additional control variable in Column (6). A one-percent increase in the total horse power of steam engines in a department in 1860-1865 increased GDP per capita by 0.102 percent in 1860, 0.231 in 1901 and 0.099 percent in 1930. As such, if a department had increased its total horse power of steam engines

\footnotetext{
${ }^{20}$ Given data limitation on income per capita across departments in the post-industrial survey period (as elaborated in section 2), the immediate effect of industrialization on income per capita is captured by its impact in 1860, its short-run effect by its impact in 1901, its medium-run effect by its impact in 1930, while its long-run effect is captured by its impact on the average level of income per capita across departments over the 2001-2005 period.
} 
Table 5: Industrialization and income per capita, $1860 \& 1901$

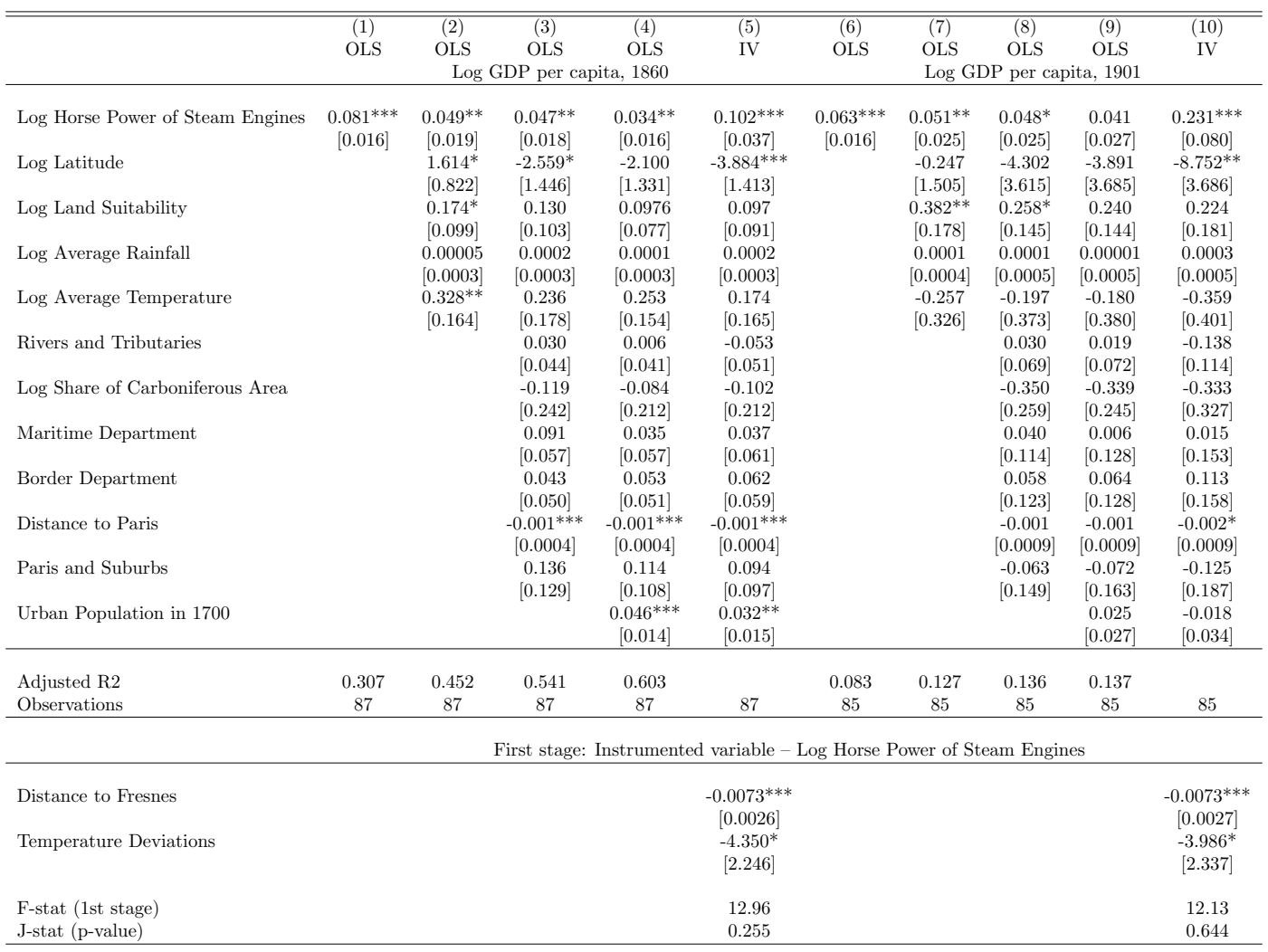

Note: This table presents OLS and IV regressions relating the horse power of steam engines in 1860-1865 to log GDP per capita in 1860 and 1901. All regressions include a dummy variable for the three departments which had no steam engine in 1860-1865. The Alsace-Lorraine variable is omitted from the regressions since the Alsace-Lorraine region was not part of France between 1871 and 1914. Aerial distances are measured in kilometers. Other explanatory variables, except the dummies, and the dependent variables are in logarithm. Heteroskedasticity-robust standard errors are reported in brackets. $* * *$ indicates significance at the $1 \%$-level, ** at the $5 \%$-level, * at the $10 \%$-level.

in 1860-1865 from the 40th percentile (380 hp) to the 60 th percentile $(762 \mathrm{hp})$ of the distribution, it would have experienced an increase in GDP per capita of 10.25 percent in 1860, 23.22 percent in 1901 and 10.04 percent in 1930.

The relationship between industrialization and income per capita in the long-run is presented in the last six columns of Table 6. As shown in Column (7), unconditionally, the horse power of steam engines in industrial production in 1860-1865 has a significant positive association with the average level of income per capita across departments over the 2001-2005 period. Moreover, this relationship remains positive, although smaller and ultimately insignificant, once one progressively accounts for the confounding effects of exogenous geographical factors (Column (8) in Table 6), institutional factors (Column (9) in Table 6) and pre-industrial characteristics (Column (10) in Table 6). However, once the effect of omitted variables is accounted for, the IV estimation in Column (11) in Table 6, suggests that the horse power of steam engines in 1860-1865 had a negative and significant impact on the average level of income per capita across departments over the 2001-2005 period. A one-percent increase in the total horse power of steam engines in 1860-1865 decreased GDP per capita in 2001-2005 by 0.060 percent. In other words, if a department had experienced an increase in its horse power in $1860-1865$ from the 40 th percentile $(380 \mathrm{hp})$ to the 60 th percentile $(762 \mathrm{hp})$ of the 
Table 6: Industrialization and income per capita, 1930 \& 2001-2005

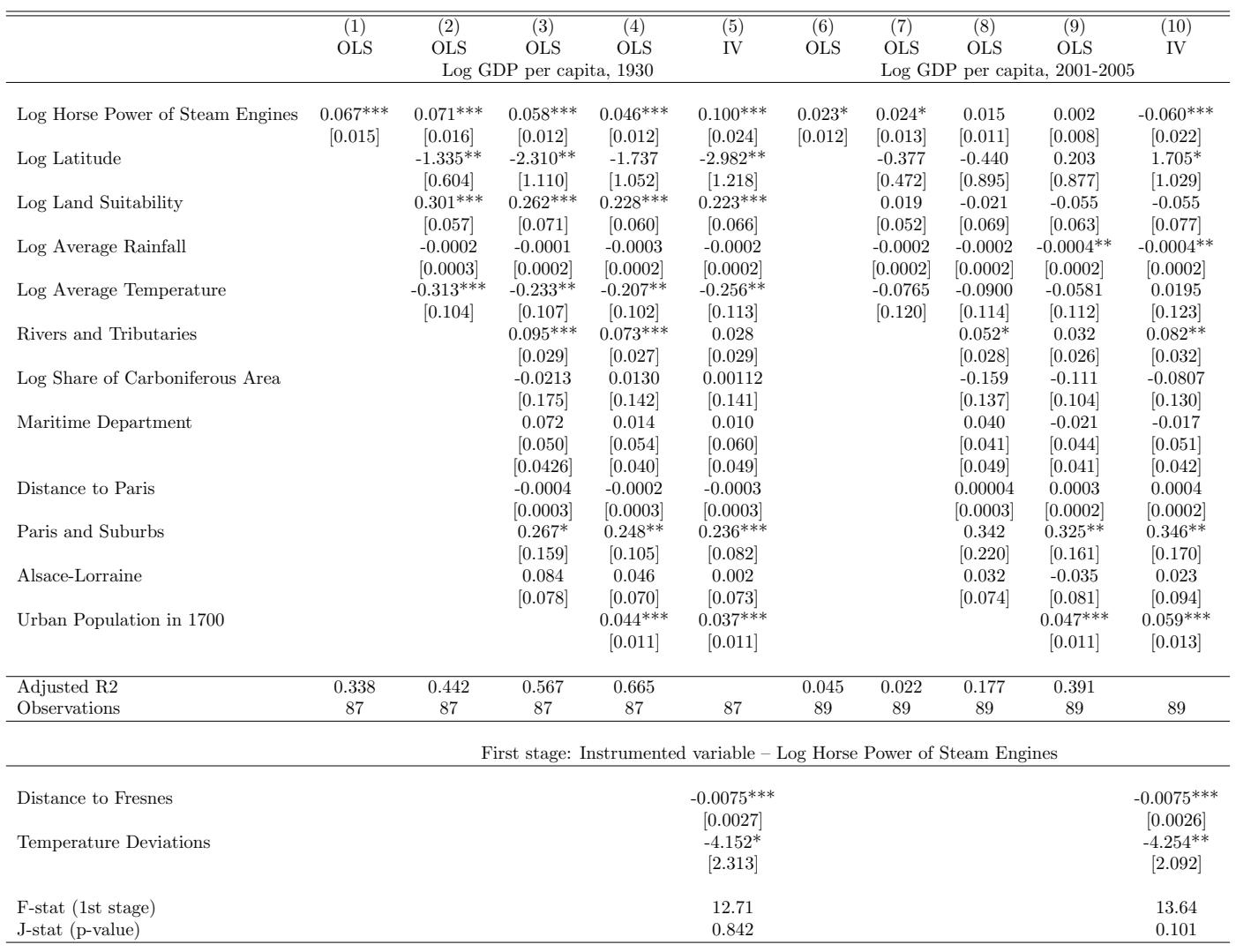

Note: This table presents OLS and IV regressions relating the horse power of steam engines in 1860-1865 to log GDP per capita in 1930 and 2001-2005. All regressions include a dummy variable for the three departments which had no steam engine in 1860-1865. Aerial distances are measured in kilometers. Other explanatory variables, except the dummies, and the dependent variables are in logarithm. Heteroskedasticity-robust standard errors are reported in brackets. *** indicates significance at the $1 \%$-level, ** at the $5 \%$-level, * at the $10 \%$-level.

distribution, this increase would have led to a 6.06 percent decrease in GDP per capita in 2001-2005. The validity of the IV regression in Column (11) is confirmed by the reduced form regression plots in Figure B.1 in the Appendix where our two instruments Distance to Fresnes and Temperature Deviations are shown to have a significant impact on income per capita in 2001-2005.

It is important to note that the IV estimation reverses the OLS estimates of the relationship between industrialization and the long-run level of income per capita from a positive to a negative one. This reversal suggests that factors which fostered industrial development, rather than industrialization per se, contributed to the positive association between industrialization and long-run development. In particular, once one accounts for the effect of these omitted factors, industrialization has an adverse effect on the standard of living in the long-run. In contrast, in earlier periods (i.e., 1860, 1901, and 1930) when industrialization contributed to economic development, the net effect of industrialization could have been obscured by these omitted characteristics (e.g., state capacity) that while being instrumental for industrialization, were associated with the protection of the agricultural sector, reducing income per capita and thus lowering its estimated association with industrialization. Consequently, once the net effect of industrialization is accounted for, the IV coefficient is significantly larger. 
In particular, as discussed in Section 2.3, the regressions in Tables 5 and 6 account for a large number of confounding geographical and institutional factors. First, the climatic and soil characteristics of each department (i.e., land suitability, average temperature, average rainfall, and latitude) could have affected natural land productivity and therefore the feasibility and profitability of the transition to the industrial stage of development, as well as the evolution of aggregate productivity in each department. Indeed, as predicted, land suitability had a significantly negative association with income per capita in 1901 and 1930 in the IV regressions (Column (10) in Table 5 and Column (5) in Table 6), suggesting that more productive land had an adverse effect on the incentive to adopt the industrial technology. Moreover, the latitude of each department had a positive and significant relationship with income per capita in 1901 and 1930 (Columns (7) to (10) in Table 5 and Columns (2) to (5) in Table 6), capturing characteristics of northern departments which were conducive to economic prosperity. Moreover, the lack of statistical significance of the geographical variables on log GDP per capita in 2000-2005 (Column (10) in Table 6) is in line with the idea that geographic characteristics do not have much of a role in the modern growth regime which is characterized by human capital accumulation (Galor, 2011).

Second, the location of departments (i.e., latitude, border departments, maritime departments, departments at a greater distance from the concentration of political power in Paris, and those that were temporarily under German domination) could have affected the diffusion of the steam engine and the diffusion of development. However, most of these factors appear orthogonal to the evolution of income per capita, except for the dummy variable for Paris and its suburbs that is significantly associated with income per capita in 1930 and in the 2001-2005 period (Columns (3) to (5) and (8) to (10) in Table 6).

Third, the regressions account for the potentially confounding effects of the level of development in the pre-industrial period, as captured by the degree of urbanization in each department in 1700 . The findings suggest that pre-industrial development (and the characteristics that may have brought this early prosperity) had a persistent positive and significant effect on later stages of development, as captured by the level of income per capita in 1930 and 2001-2005 (Columns (4), (5), (9), \& (10) in Table 6), but no robust impact on the early phases of industrialization, as captured by income per capita in 1860 and 1901 (Columns (4), (5), (9), \& (10) in Table 5). Moreover, as established in Table B.2, if one accounts for a possible common spatial pattern between the two instruments and uses the residual from the regression of Distance to Fresnes on Temperature Deviations as an instrumental variable, the results are stronger economically and statistically.

Finally, as established in Tables B.12-B.17 in the Appendix, the association between intensity of the steam engines and income per capita in 1861, 1901, 1930 and 2001-2005 is not affected by spatial correlation or by clustering the standard errors at the regional level (using the current 13 administrative regions of the French territory).

\subsection{Industrialization \& Income: Accounting for other Confounding Factors}

This section examines the robustness of the baseline analysis to the inclusion of an additional set of confounding geographical, demographic, political and institutional characteristics, as well as for the forces of pre-industrial development, which may have contributed to the relationship between industrialization and economic development. The analysis focuses on the potential impact of these confounding factors on the IV regressions in Tables 5 and 6 . As will become apparent, some of these confounding factors could be viewed 
as "bad controls", i.e., as endogenous to the adoption of the steam engine, and they are thus not part of the baseline analysis.

\subsubsection{Initial Level of Income per Capita}

The non-monotonic impact of industrialization on the evolution of income per capita precludes direct concerns about the adverse effect of the initial level of income per capita on the growth of each department In particular, the convergence hypothesis would suggests that the initial positive effect of industrialization will dissipate over time, rather than turning negative. In fact, as established in Table B.19 the long-term effect of industrialization is qualitatively unaffected by the initial level of $\log$ GDP per capita in 1860. It remains positive in 1930 and even more negative in 2001-2005.

\subsubsection{Population Density}

The empirical analysis accounts for a wide range of exogenous confounding geographical and institutional characteristics, as well as for pre-industrial development, which may have contributed to the relationship between industrialization and economic development. Nevertheless, in light of the evidence that steam engines were more likely to be located in urban centers (Rosenberg and Trajtenberg, 2004), it appears plausible that the adoption of the steam engine was influenced by the contemporaneous but potentially endogenous level of population density at the time.

Reassuringly, as established in Table B.20 in the Appendix, the inclusion of population density in each French department in 1801, 1831 and 1861 has no qualitative impact on the estimated effects of industrialization or on the statistical significance of these effects. Accounting for the confounding effects of exogenous geographical, institutional, and pre-industrial characteristics, the horse power of steam engines in industrial production in the 1860-1865 period had a positive and significant impact on income per capita in 1860, and a negative and significant impact on income per capita in the years 2001-2005.

\subsubsection{Human Capital}

Considering evidence about capital-skill complementarity as well as the comparative advantage of educated individuals in adopting new technologies (Nelson and Phelps, 1966), the diffusion of the steam engine could have been affected by the level of human capital in each department. Using data on the presence of a university in 1700 and 1793, the percentage of French army conscripts who could at least read in 1827-1829 and 1831-1835 (which could be endogenous the process of industrialization) and on the percentage of grooms who could sign their marriage license in 1686-1690 and 1786-1790, it appears in Tables B.21, B.22 and B.23 that these measures of human capital have no qualitative impact on the estimated effects of industrialization. In particular, accounting for the confounding effects of exogenous geographical, institutional, and pre-industrial characteristics, industrialization had a positive and significant impact on income per capita in 1860, but no significant impact on income per capita in 2001-2005. 


\subsubsection{Share of Jews and Protestants in the Population}

In light of the evidence about the importance of the Jewish and the Protestant population for entrepreneurial activities (e.g., Weber (1930)), the adoption of the steam engine in France as well as the process of development could have been affected by the variations in the share of these religious minorities across departments. As shown in Table B.24 in the Appendix, accounting for the shares of Jews and Protestants in the French population in 1861 (i.e., when the industrial survey was conducted) has no qualitative impact on the effect of industrialization on income per capita in 1860 and 2001-2005.

\subsubsection{The Early Use of Raw Material}

As was shown in the baseline regressions in Tables 5 and 6 , the statistical impact of industrialization remains intact when one accounts for the share of carboniferous area in each department (Fernihough and O'Rourke, 2014). Nonetheless, the diffusion of the steam engine across French departments as well as the process of development could have been affected by the early use of raw material required for industrialization. Our regressions reported in Tables B.25 and B.26 however show that this is not the case. First, as established in Table B.25, accounting for the number of iron forges in 1789 and 1811 in each department, the effect of industrialization on income per capita in the process of development remains nearly intact, economically and statistically. Second, as shown in Table B.26, accounting for the area covered by coal mines in 1837 in each department, the effect of industrialization on income per capita in the process of development remains qualitatively intact.

\subsubsection{Economic Integration}

The diffusion of the steam engine across French departments as well as the process of development could have been affected by the degree of geographical and economic integration of each department into the French economy. ${ }^{21}$ First, as reported in Table B.27, the degree of market integration of each department in the 1790s, as captured by the number of firms which were located in one department but sold their products outside that department (Daudin, 2010), has no qualitative impact on the effect of industrialization on income per capita in the process of development. Second, as reported in Table B.28, accounting for the presence of railroad connection in $1860,{ }^{22}$ the effect of industrialization on income per capita in the process of development remains nearly intact, economically and statistically.

\subsubsection{Industrial Concentration and Firm Size}

The degree of industrial concentration in each department could have affected the diffusion of the steam engine across French departments as well as the process of development. Nevertheless, as reported in Table B.29, accounting for the degree of industrial concentration in the 1860-1865 period, proxied by the Herfindahl index of the horse power for the 16 different industries listed in the 1860-1865 industrial survey (textile, mines, metallurgy, metal objects, leather, wood, ceramics, chemistry, construction, lighting, furniture, clothing,

\footnotetext{
${ }^{21}$ See Donaldson (2015) for a recent survey of the impact of market integration.

${ }^{22}$ The early network was built around seven lines in order to connect Paris to the main economic centers of the country (Caron, 1997).
} 
food, transportation, sciences \& arts, and luxury goods), the effect of industrialization on income per capita in the process of development remains nearly intact, economically and statistically. ${ }^{23}$ Moreover, as shown in Table B.30, the economic and statistical impact of industrialization on income per capita remains nearly intact when one accounts for the Herfindahl index based on industry-specific employment shares. In addition, we account for the possibility that the size of the firms in 1860-1865, as proxied by the number of employees per firm in each department, would depress income per capita in the long-run because large firms are less likely to adopt new technologies and could become an impediment to entrepreneurship. The results in Table B.31 however show that accounting for the number of employees per firm does not modify the statistical and economic impact of industrialization on income per capita in the short- and in the long-run.

\subsection{External Validity and Policy Implications}

This section examines the external validity of the finding that industrialization is detrimental to long-run prosperity for less-developed societies. If one views each French department as a small-open economy, one may argue that the proper industrial policy ought to encourage the development of skilled-intensive sectors rather than of the traditional unskilled-intensive sectors.

However, one concern could be the negative effect of industrialization in the long-run at the departmental level does not reflect the overall effect of industrialization. A priori, it is possible that industrialization generated technological spillovers such that the most industrialized department within a region declined but the region prospered as a whole due to the spillovers from this industrialization process. In order to explore this important possibility, Table B.18 analyzes the effect of industrialization at the regional level (using the current administrative divisions of France into 12 regions, each of which consists approximately of seven departments). Importantly, the results in Table B.18 demonstrate that the regions, as a whole, experienced an identical pattern, i.e., a increase in prosperity in the short-run and a decline in in the long-run. Nevertheless, our empirical analysis suggests that the negative impact of industrialization on long-run prosperity in one department did not generate sufficiently positive spillovers in neighboring departments so as to avert the adverse effects of industrialization on long-run prosperity of the region as a whole. ${ }^{24}$

Furthermore, when considering industrial policy in currently less developed societies, one has to account for the fact that those societies could adopt existing technologies of various degrees of skill-intensity. Namely, less developed countries do not need to develop less-skilled industries in order to adopt skilled-intensive ones. In this respect, the departmental level analysis of France suggests that less developed societies ought to promote the development of skilled-intensive sectors rather than an unskilled intensive industrial sector.

\footnotetext{
${ }^{23}$ The Herfindahl index of industry concentration is defined as, $H_{d}=\sum_{i=1}^{16}\left(E_{i, d} / E_{d}\right)^{2}$, where $H_{d}$ is the Herfindahl concentration index for department $d, E_{i, d}$ is the horse power of the steam engines in the firms in sector $i$ of department $d$ and $E_{d}$ is the horse power of the steam engines in the firms of department $d$.

${ }^{24}$ Distances from Fresnes-sur-Escaut to each department are powerful predictors of the intensity of the use of steam engines in 1860-65 across French departments as a whole. However, distances from Fresnes-sur-Escaut are not sufficiency refined to provide a significant prediction of the variations in the use of the steam engine across nearby departments within each of 12 contemporary regions of France. Hence, one cannot use the proposed IV strategy to test for the reversal within each of these 12 regions (i.e., across 7 nearby departments on average). Nevertheless, reassuringly, as established in Table B.18, the reversal in the effect of the industrialization on long run prosperity is highly significant across these 12 regions as well.
} 


\section{$5 \quad$ Mechanisms}

This section explores several potential mechanisms that could have led to the detrimental effect of industrialization on the standard of living in the long-run. The analysis suggests that the adverse effect of earlier industrialization on long-run prosperity can be attributed to the negative impact of the intensive use of unskilled-intensive technologies in the early stages of industrialization on the long-run level of human capital and thus on the incentive to adopt skill-intensive technologies in the contemporary era. The adverse effect of industrialization on long-run prosperity reflects a dual techno-cultural lock-in effect characterized by cultural inertia in the intergenerational transmission of a lower predisposition towards investment in human capital along with technological inertia manifested by the persistence predominance of low-skilled-intensive industries.

Consistent with the proposed techno-cultural dual lock-in hypothesis, the empirical analysis exploits individual data on education achievements of over 2100 second generation migrants to establish that acquired comparative advantage in the unskilled-intensive industrial sector has ultimately depressed the demand for human capital and have triggered a cultural process characterized by intergenerational transmission of lower educational aspirations. Furthermore, using individual data on the composition of employment across sectors among over 1.1 million individuals, the study suggests that this cultural inertia, and its adverse effect on human capital formation in the long-run, has further hindered the incentive of competitive industries to adopt more lucrative skilled-intensive technologies, reinforcing the suboptimal level of human capital formation and reducing the standards of living in the long-run. Interestingly, the findings suggest that the adverse effect of earlier industrialization on long-run prosperity does not reflect a delayed transition from the industrial to the service sector, but rather the lower skill-intensity of occupations in the service as well as in the industrial sector in historically industrial regions.

The empirical analysis further establishes that various ex-ante plausible channels do not account for the adverse effect of early industrialization on long-run prosperity: (1) the contribution of industrialization to unionization and wage rates in historically industrialized regions and the comparative decline of these regions in the long-run due to the incentive of modern industries to locate in regions where labor markets are more competitive, (2) the effect of trade protection in traditional industries on the decline in the long-run competitiveness of historically industrialized regions, (3) the potential negative effect of disproportional destruction of industrialized regions during WWI and WWII on the subsequent development of these regions, (4) the persistent adverse effect of selective migration (e.g. immigration of unskilled workers into industrialized regions, or the emigration of more educated workers into less industrialized regions), on the composition of human capital and long-run income per capita in historically industrialized regions, and (5) the dispro-

portionate public investment in human capital in non-industrial regions. Moreover, the empirical analysis demonstrates that the adverse effect of industrialization on long-run prosperity has not been mitigated by the positive effect of early industrialization on population density in historically industrialized regions and its beneficial effects via the spillover from agglomeration to long-run development. 


\subsection{Industrialization and the Dual Techno-Cultural Lock-In Effect}

This section provides supporting evidence for the hypothesis that the adverse effect of industrialization on long-run prosperity can be attributed to a dual techno-cultural lock-in effect. In particular, it demonstrates that the effect of early industrialization on acquired comparative advantage in the unskilled-intensive industrial sector depressed the demand for human capital and have triggered cultural inertia, characterized by a lower predisposition towards investment in human capital, that has further hindered the incentive of firms to adopt skilled-intensive technologies, adversely effecting human capital formation and the standards of living in the long-run.

The empirical support for the hypothesized dual lock-in effect is based on three findings. First, the analysis establishes that indeed industrialization have an adverse effect on human capital formation in the long-run. Second, it demonstrates the existence of a cultural lock-in effect, reflected by the persistent effect of historical industrialization on investment in human capital among second generation migrants who are no longer residing in these industrial regions. Third, it suggests that under investment in human capital affected the contemporary composition of industries in historically industrial regions and reinforced the specialization in unskilled-intensive industries.

\subsubsection{Industrialization and the Evolution of Human Capital}

This subsection explores the validity of the first building block of the hypothesized dual techno-cultural lock-in effect that has governed the detrimental effect of industrialization on the standard of living in the long-run. It establishes the adverse effect of historically industrialized regions on the the contemporary level of human capital and thus on the skill-intensity of the production process in these regions in the long-run.

The horse power of steam engines in industrial production in 1860-1865 had a progressively larger adverse effect on the share of men age 25 and above who had at least high-school degree in the past few decades as reported in the IV regressions in Table 7). ${ }^{25}$ These adverse effects are statistically significant in $1975,1982,1990,1999$ and $2010 .^{26}$

Moreover, as reported in the IV regressions in Table 8, the horse power of steam engines in industrial production in 1860-1865 has a highly significant negative effect on human capital formation in the long-run, as captured by the shares of male age 15-17 or 18-24, who attended school in 201 (note that school attendance is mandatory in France until age 16). These regressions indicate that in departments which utilized the steam engine more intensively 150 years ago, a smaller fraction of men age 15-17 remain in high-school and a smaller fraction of men age 18-24 study in institutions of higher learning. ${ }^{27}$ As will become apparent, some of this adverse effect on human capital formation can be attributed to cultural inertia and its effect on reduced educational aspiration among individuals from historically intensive industrial regions.

\footnotetext{
${ }^{25}$ As established by Franck and Galor (2017), due to capital-skill complementarity, intensive industrialization in the middle of the 19th century had a significantly positive effect on human capital formation in the subsequent decades in France (as well as in other industrial nations (Galor and Moav, 2006)). Nevertheless, as the novelty of the industrial technology diminished, the positive effects of early industrialization on human capital formation had dissipated in the early part of the 20 th century (Table D.2 in the Appendix). Instead, inertia in the use of unskilled-intensive technologies in historically intensive industrial regions, have had an adverse effect on the time path of human capital formation.

${ }^{26}$ Similar results are found for women as reported in Table D.3 in the Appendix.

${ }^{27}$ Similar results are found for school enrollment rates of women age 15-17 and 18-24 in 2010, as reported in Table D.1 in the Appendix.
} 
Table 7: Industrialization and Human Capital Formation, 1968-2010

\begin{tabular}{|c|c|c|c|c|c|c|}
\hline & $\begin{array}{l}(1) \\
\text { IV }\end{array}$ & $\begin{array}{l}(2) \\
\text { IV }\end{array}$ & $\begin{array}{l}(3) \\
\text { IV }\end{array}$ & $\begin{array}{l}(4) \\
\text { IV }\end{array}$ & $\begin{array}{l}(5) \\
\text { IV }\end{array}$ & $\begin{array}{l}6) \\
\text { IV }\end{array}$ \\
\hline & \multicolumn{6}{|c|}{ Log Post-Secondary Degree (Male 25+ } \\
\hline & 1968 & 1975 & 1982 & 1990 & 1999 & 2010 \\
\hline Log Horse Power of Steam Engines & $\begin{array}{c}-0.0558 \\
{[0.0422]} \\
\end{array}$ & $\begin{array}{c}-0.0666^{*} \\
{[0.0372]}\end{array}$ & $\begin{array}{c}-0.0854^{* *} \\
{[0.0375]}\end{array}$ & $\begin{array}{c}-0.0788^{* *} \\
{[0.0380]}\end{array}$ & $\begin{array}{c}-0.0748^{* *} \\
{[0.0355]} \\
\end{array}$ & $\begin{array}{c}-0.0846^{* *} \\
{[0.0342]} \\
\end{array}$ \\
\hline Geographic characteristics & Yes & Yes & Yes & Yes & Yes & Yes \\
\hline Institutional characteristics & Yes & Yes & Yes & Yes & Yes & Yes \\
\hline Pre-industrial development & Yes & Yes & Yes & Yes & Yes & Yes \\
\hline \multirow[t]{2}{*}{ Observations } & 89 & 89 & 89 & 89 & 89 & 89 \\
\hline & First stage: & \multicolumn{5}{|c|}{ Instrumented Variable - Log Horse Power of Steam Engines } \\
\hline Distance to Fresnes & $\begin{array}{c}-0.0064^{* *} \\
{[0.0025]}\end{array}$ & $\begin{array}{c}-0.0064^{* *} \\
{[0.0025]}\end{array}$ & $\begin{array}{c}-0.0064^{* *} \\
{[0.0025]}\end{array}$ & $\begin{array}{c}-0.0064^{* *} \\
{[0.0025]}\end{array}$ & $\begin{array}{c}-0.0064^{* *} \\
{[0.0025]}\end{array}$ & $\begin{array}{c}-0.0064^{* *} \\
{[0.0025]}\end{array}$ \\
\hline Temperature Deviations & $\begin{array}{c}-4.836^{* *} \\
{[2.306]}\end{array}$ & $\begin{array}{c}-4.836^{* *} \\
{[2.306]}\end{array}$ & $\begin{array}{c}-4.836^{* *} \\
{[2.306]}\end{array}$ & $\begin{array}{c}-4.836^{* *} \\
{[2.306]}\end{array}$ & $\begin{array}{c}-4.836^{* * *} \\
{[2.306]}\end{array}$ & $\begin{array}{c}-4.836^{* *} \\
{[2.306]}\end{array}$ \\
\hline F-stat & 14.40 & 14.40 & 14.40 & 14.40 & 14.40 & 14.40 \\
\hline J-stat (p-value) & 0.800 & 0.861 & 0.709 & 0.628 & 0.712 & 0.825 \\
\hline
\end{tabular}

Note: This table presents OLS and IV regressions relating the horse power of steam engines in 1860-1865 to the evolution in the share of men age 25 and above with a post-secondary degree between 1968 and 2010. All regressions include a dummy variable for the three departments which had no steam engine in 1860-1865. Aerial distances are measured in kilometers. Other explanatory variables, except the dummies, and the dependent variables are in logarithm. Geographic characteristics include the department's latitude, land suitability, average rainfall and temperature, share of carboniferous area, distance to Paris as well as dummies for the presence of rivers and tributaries, maritime and border departments. Institutional measures include dummies for Alsace-Lorraine and for Paris and its suburbs. Pre-industrial development characteristics include a measure of the urban population in 1700. Heteroskedasticity-robust standard errors are reported in brackets. *** indicates significance at the $1 \%$-level, ** at the $5 \%$-level, * at the $10 \%$-level.

Table 8: Early Industrialization and School Enrollment in 2010

\begin{tabular}{|c|c|c|c|c|c|c|}
\hline & $\begin{array}{l}(1) \\
\text { OLS }\end{array}$ & $\begin{array}{l}(2) \\
\text { OLS }\end{array}$ & $\begin{array}{ll}(3) \\
\text { IV }\end{array}$ & $\begin{array}{l}(4) \\
\text { OLS }\end{array}$ & $\begin{array}{l}(5) \\
\text { OLS }\end{array}$ & (6) \\
\hline & \multicolumn{6}{|c|}{ Log School Enrollment (Male) } \\
\hline & \multicolumn{3}{|c|}{$15-17$} & \multicolumn{3}{|c|}{$18-24$} \\
\hline Log Horse Power of Steam Engines & $\begin{array}{l}-0.0002 \\
{[0.0008]}\end{array}$ & $\begin{array}{l}-0.0006 \\
{[0.0007]}\end{array}$ & $\begin{array}{c}-0.010^{* * *} \\
{[0.003]}\end{array}$ & $\begin{array}{c}0.010 \\
{[0.009]}\end{array}$ & $\begin{array}{l}-0.014 \\
{[0.011]}\end{array}$ & $\begin{array}{c}-0.076^{* * *} \\
{[0.025]}\end{array}$ \\
\hline Geographic characteristics & No & Yes & Yes & No & Yes & Yes \\
\hline Institutional characteristics & No & Yes & Yes & No & Yes & Yes \\
\hline Pre-industrial development & No & Yes & Yes & No & Yes & Yes \\
\hline Adjusted R2 & -0.020 & 0.117 & & 0.007 & 0.408 & \\
\hline Observations & 89 & 89 & 89 & 89 & 89 & 89 \\
\hline \multicolumn{7}{|c|}{ First stage: Instrumented variable - Log Horse Power of Steam Engines } \\
\hline Distance to Fresnes & & & $\begin{array}{c}-0.0075^{* * *} * \\
{[0.0026]}\end{array}$ & & & $\begin{array}{c}-0.0075^{* * *} \\
{[0.0026]}\end{array}$ \\
\hline Temperature Deviations & & & $\begin{array}{c}-4.254^{* *} \\
{[2.092]}\end{array}$ & & & $\begin{array}{c}-4.254^{* *} \\
{[2.092]}\end{array}$ \\
\hline F-stat (1st stage) & & & 13.64 & & & 13.64 \\
\hline J-stat (p-value) & & & 0.123 & & & 0.874 \\
\hline
\end{tabular}

Note: This table presents OLS and IV regressions relating the horse power of steam engines in 1860-1865 to the share of school enrollment for men age $15-17$ and 18-24. All regressions include a dummy variable for the three departments which had no steam engine in 1860-1865. Aerial distances are measured in kilometers. Other explanatory variables, except the dummies, are in logarithm. Geographic characteristics include the department's latitude, land suitability, average rainfall and temperature, share of carboniferous area, distance to Paris as well as dummies for the presence of rivers and tributaries, maritime and border departments. Institutional measures include dummies for Alsace-Lorraine and for Paris and its suburbs. Pre-industrial development characteristics include a measure of the urban population in 1700 . Heteroskedasticity-robust standard errors are reported in brackets $* * *$ indicates significance at the $1 \%$-level, ** at the $5 \%$-level, * at the $10 \%$-level. 


\subsubsection{Cultural Persistence of Predisposition Towards Investment in Human Capital}

This subsection demonstrates the existence of a cultural lock-in effect in the formation of human capital, reflected by the persistent effect of historical industrialization on investment in human capital and aspiration with respect to human capital among the descendants of these historically intensive industrial regions. In particular, it demonstrates that the effect of early industrialization on acquired comparative advantage in the unskilled-intensive industrial sector depressed the demand for human capital and have triggered cultural inertia, characterized by a lower predisposition towards investment in human capital, that has further hindered the incentive of firms to adopt more lucrative skilled-intensive technologies, adversely effecting human capital formation and the standards of living in the long-run.

Following the epidemiological approach for the study of cultural persistence, the study exploits data on second generation migrants (i.e., individuals who live in their birth department whose parents are originated from a different department within France) to establish the presence of cultural inertia in the formation of human capital among the decedents of these historically intensive industrial regions. The analysis of second-generation migrants accounts for time invariant unobserved heterogeneity in the host department (e.g., geographical, cultural and institutional characteristics), mitigating possible concerns about the confounding effect of host department-specific characteristics. Moreover, since the historical industrial intensity in the parental department of origin is distinct from the historical industrial intensity in the individual's department of residence, the estimated effect of industrial intensity in the parental department of origin on their human capital formation captures the culturally embodied, intergenerationally transmitted effect of industrial intensity on human capital aspirations, rather than the direct effect of industrial intensity.

Table 9: Industrialization and Human Capital Inertia: Second-Generation Migrants

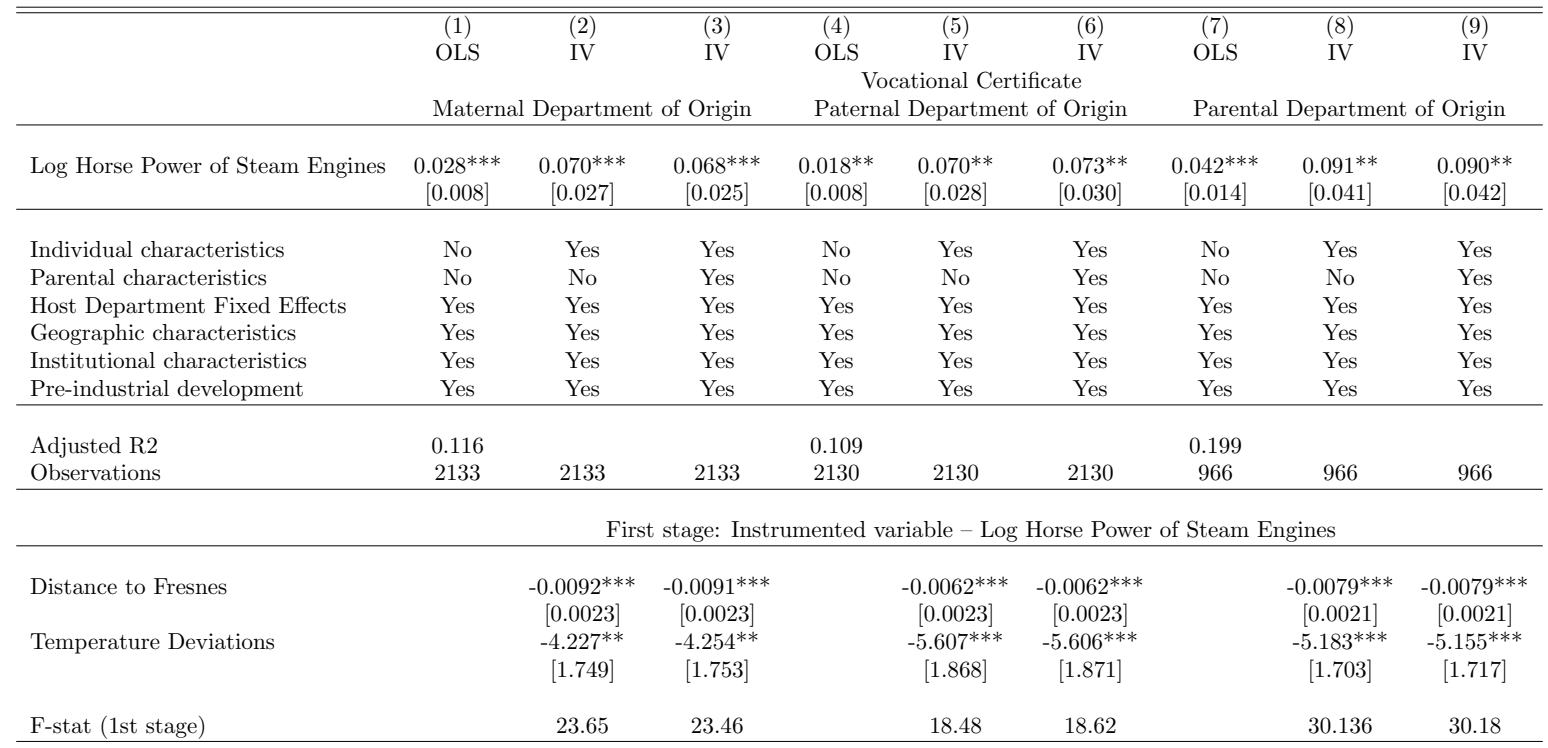

Note: This table presents OLS and IV regressions relating the horse power of steam engines in $1860-1865$ in the origin department for the parents of second generation migrants to the probability that the highest educational qualification of these second generation migrants is a vocational certificate that is usually
obtained around age $14-15$. All regressions include fixed effects for the respondent's birth department. The control variables refer to the origin department of the respondent's mother (Columns (1)-(3)), father (Columns (4)-(6)) and both parents (Columns (7)-(9)). Aerial distances are measured in kilometers. Other explanatory variables, except the dummies, and the dependent variables are in logarithm. Individual characteristics include the respondent's age and gender. Parental characteristics include dummies indicating whether the respondent's father or mother were workers. Geographic characteristics include the of rivers and tributaries, maritime and border departments. Institutional measures include dummies for Alsace-Lorraine and for Paris and its suburbs. Preindustrial development characteristics include a measure of the urban population in 1700 . Heteroskedasticity-robust standard errors are reported in brackets. $* * *$ indicates significance at the $1 \%$-level, $* *$ at the $5 \%$-level, * at the $10 \%$-level. 
Table 10: Industrialization and Human Capital Inertia: Second-Generation Migrants

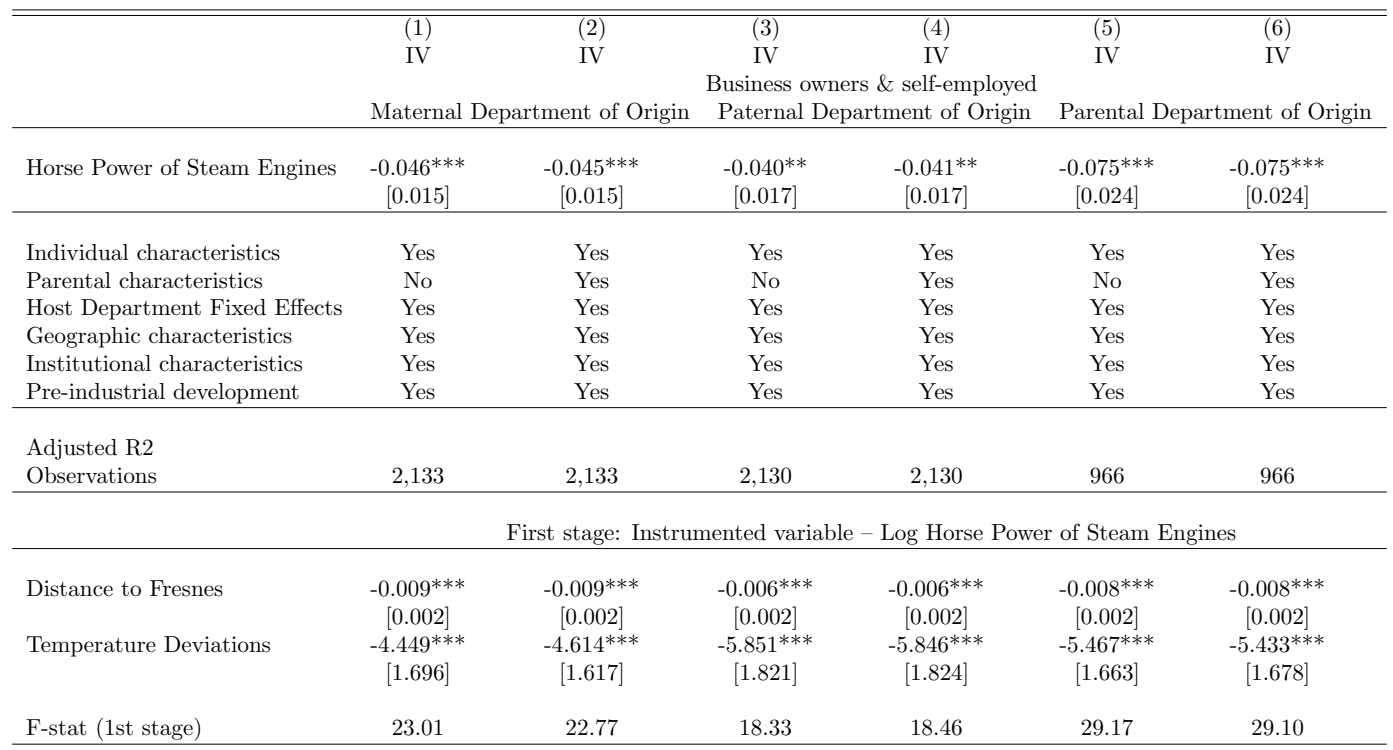

Note: This table presents IV regressions relating the horse power of steam engines in 1860-1865 in the origin department for the parents of second generation migrants to the probability that these second generation migrants are self-employed and/or business owners. All regressions include fixed effects for the (4) and both parents (Columns (5)-(6)). A erial distances are measured in kilometers. Other explanatory variables, except the dummies, and the dependent variables are in respondent's father or mother were workers. Geographic characteristics include the department's latitude, land suitability, average rainfall and temperature, share of carboniferous area, distance to Paris as well as dummies for the presence of rivers and tributaries, maritime and border departments. Institutional measures include dummies for Alsace-Lorraine and for Paris and its suburbs. Pre-industrial development characteristics include a measure of the urban population in 170 -level.

The analysis finds that second generation migrants whose parents were originated in historically industrial regions are significantly more likely to have:(i) low human capital aspirations, as reflected by their acquisition of vocational education and their departure from the the schooling system in the end of the middle school, and (ii) diminished entrepreneurial spirit. Furthermore, accounting for the parental occupation, the effects remains highly significant. This result lend credence to the presence of cultural inertia that contributed to technological inertia and triggered the dual lock-in effect. In particular, using a representative labor survey carried out in 2005, Table 9 shows that the highest educational degree of these second-generation migrants was a Certificat d'Aptitude Professionnelle, i.e., a two-year vocational degree which is taken around age 14-15, and Table 10 establishes, that among these second-generation migrants there is a lower propensity of owning a business and to be self employed. ${ }^{28}$

Consistent with these findings, Table 11 shows that early industrialization is associated a lower contemporary valuation of science. In particular, individuals who are currently employed in a department that has a higher intensity steam engines 150 years ago express no interest in science and who report not using science in their current work in a survey carried out in 2001 (Centre de recherches politiques de Sciences Po, Enquête science 2001).

\footnotetext{
${ }^{28}$ On entrepreneurship in France, see notably Aghion et al. (2017).
} 
Table 11: Industrialization and Contemporary Educational Aspirations: Lack of Interest in Science

\begin{tabular}{lcc}
\hline \hline & $(1)$ & $(2)$ \\
& IV & IV \\
& No Interest & No Use in Work \\
\hline \multirow{2}{*}{ Log Horse Power of Steam Engines } & $0.061^{* *}$ & $0.109^{* *}$ \\
& {$[0.024]$} & {$[0.055]$} \\
\hline \multirow{2}{*}{ Individual characteristics } & Yes & Yes \\
Geographic characteristics & Yes & Yes \\
Institutional characteristics & Yes & Yes \\
Pre-industrial development & Yes & Yes \\
\hline \multirow{3}{*}{ Observations } & 1337 & 1276 \\
\hline \multirow{3}{*}{ First stage: Instrumented variable - Log Horse Power of Steam Engines } \\
\hline \multirow{3}{*}{ Distance to Fresnes } & $-0.0054^{* *}$ & $-0.0054^{* *}$ \\
Temperature Deviations & {$[0.0022]$} & {$[0.0021]$} \\
& $-4.327^{* *}$ & $-4.034^{* *}$ \\
F-stat (1st stage) & {$[1.896]$} & {$[1.869]$} \\
J-stat (p-value) & 11.90 & 11.21 \\
\hline
\end{tabular}

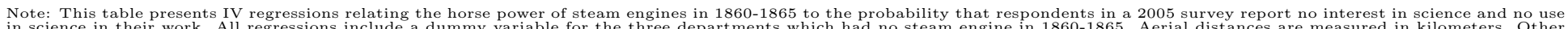

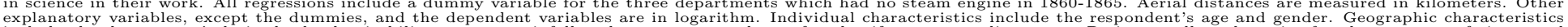

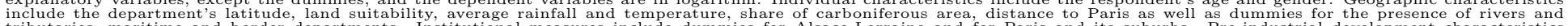

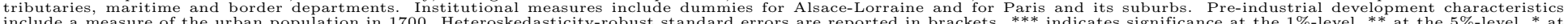
the $10 \%$-level.

Table 12: Industrialization, Modern Measures of Human Capital and Entrepreneurship, and Income in 2001-2005: Channels

\begin{tabular}{|c|c|c|c|c|c|c|c|c|c|}
\hline & $\begin{array}{c}(1) \\
\text { IV } \\
\text { Log Post-Secondary Degree } \\
\text { Male } 25+, 2010 \\
\end{array}$ & $\begin{array}{c}(2) \\
\text { IV } \\
\text { Log School } \\
15-17,2010 \\
\end{array}$ & $\begin{array}{c}(3) \\
\text { IV } \\
\text { collment (Male) } \\
18-24,2010 \\
\end{array}$ & $\begin{array}{c}\text { IV } \\
\text { IV } \\
\text { Business owners \& } \\
\text { self-employed } \\
\end{array}$ & \multicolumn{4}{|c|}{$\begin{array}{c}\text { Log GDP per capita } \\
\text { 2001-2005 }\end{array}$} & $\begin{array}{l}(9) \\
\text { IV }\end{array}$ \\
\hline $\begin{array}{l}\text { Log Horse Power of Steam Engines } \\
\text { Log Post-Secondary Degree } \\
\text { Male } 25+, 2010 \\
\text { Log School Enrollment (Male) } \\
\text { 15-17, } 2010 \\
\text { Log School Enrollment (Male) } \\
\text { 18-24, } 2010 \\
\text { Business owners \& self-employed } \\
\text { (Maternal Department of Origin) }\end{array}$ & $\begin{array}{c}-0.0846^{* *} \\
{[0.0342]}\end{array}$ & $\begin{array}{c}-0.0097^{* * *} \\
{[0.0027]}\end{array}$ & $\begin{array}{c}-0.0763^{* * *} \\
{[0.0251]}\end{array}$ & $\begin{array}{c}-0.0452^{* * *} \\
{[0.0147]}\end{array}$ & $\begin{array}{c}-0.060^{* * *} \\
{[0.022]}\end{array}$ & $\begin{array}{c}-0.0154 \\
{[0.0145]} \\
0.509^{* * *} \\
{[0.0584]}\end{array}$ & $\begin{array}{c}-0.0273^{*} \\
{[0.0164]} \\
\\
3.163^{* * *} \\
{[0.991]}\end{array}$ & $\begin{array}{l}-0.0269 \\
{[0.0195]}\end{array}$ & $\begin{array}{c}-0.0489^{* * *} \\
{[0.004]}\end{array}$ \\
\hline $\begin{array}{l}\text { Individual characteristics } \\
\text { Parental characteristics } \\
\text { Host Department Fixed Effects } \\
\text { Geographic characteristics } \\
\text { Institutional characteristics } \\
\text { Pre-industrial development }\end{array}$ & $\begin{array}{l}\text { No } \\
\text { No } \\
\text { No } \\
\text { Yes } \\
\text { Yes } \\
\text { Yes }\end{array}$ & $\begin{array}{l}\text { No } \\
\text { No } \\
\text { No } \\
\text { Yes } \\
\text { Yes } \\
\text { Yes }\end{array}$ & $\begin{array}{l}\text { No } \\
\text { No } \\
\text { No } \\
\text { Yes } \\
\text { Yes } \\
\text { Yes }\end{array}$ & $\begin{array}{l}\text { Yes } \\
\text { Yes } \\
\text { Yes } \\
\text { Yes } \\
\text { Yes } \\
\text { Yes }\end{array}$ & $\begin{array}{l}\text { No } \\
\text { No } \\
\text { No } \\
\text { Yes } \\
\text { Yes } \\
\text { Yes }\end{array}$ & $\begin{array}{l}\text { No } \\
\text { No } \\
\text { No } \\
\text { Yes } \\
\text { Yes } \\
\text { Yes }\end{array}$ & $\begin{array}{l}\text { No } \\
\text { No } \\
\text { No } \\
\text { Yes } \\
\text { Yes } \\
\text { Yes }\end{array}$ & $\begin{array}{l}\text { No } \\
\text { No } \\
\text { No } \\
\text { Yes } \\
\text { Yes } \\
\text { Yes }\end{array}$ & $\begin{array}{l}\text { Yes } \\
\text { Yes } \\
\text { Yes } \\
\text { Yes } \\
\text { Yes } \\
\text { Yes }\end{array}$ \\
\hline Observations & 89 & 89 & 89 & 2,133 & 89 & 89 & 89 & 89 & 2,133 \\
\hline \multicolumn{10}{|c|}{ First stage: Instrumented variable - Log Horse Power of Steam Engines } \\
\hline $\begin{array}{l}\text { Distance to Fresnes } \\
\text { Temperature Deviations }\end{array}$ & $\begin{array}{c}-0.0064^{* *} \\
{[0.0025]} \\
-4.836^{* *} \\
{[2.306]}\end{array}$ & $\begin{array}{c}-0.0075^{* * *} \\
{[0.0026]} \\
-4.254^{* *} \\
{[2.092]}\end{array}$ & $\begin{array}{c}-0.0075^{* * *} \\
{[0.0026]} \\
-4.254^{* *} \\
{[2.092]}\end{array}$ & $\begin{array}{c}-0.0091^{* * *} \\
{[0.0022]} \\
-4.614^{* * *} \\
{[1.617]}\end{array}$ & $\begin{array}{c}-0.0075^{* * *} \\
{[0.0026]} \\
-4.254^{* *} \\
{[2.092]}\end{array}$ & $\begin{array}{c}-0.0070^{* * *} \\
{[0.0026]} \\
-5.136^{* *} \\
{[2.117]}\end{array}$ & $\begin{array}{c}-0.0107^{* * *} \\
{[0.0035]} \\
-5.146^{* *} \\
{[2.087]}\end{array}$ & $\begin{array}{c}-0.0064^{* *} \\
{[0.0026]} \\
-5.015^{* *} \\
{[2.350]}\end{array}$ & $\begin{array}{c}-0.0087^{* * *} \\
{[0.0005]} \\
-3.180^{* * *} \\
{[0.483]}\end{array}$ \\
\hline F-stat (1st stage) & 14.40 & 13.64 & 13.64 & 22.77 & 13.64 & 14.58 & 9.37 & 11.24 & 335.85 \\
\hline
\end{tabular}

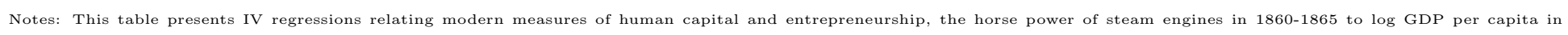

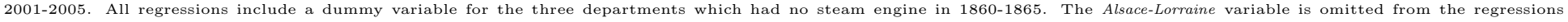

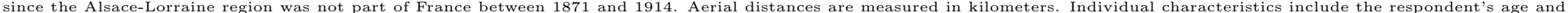

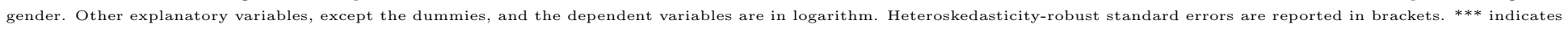
significance at the $1 \%$-level, ${ }^{* *}$ at the $5 \%$-level, ${ }^{*}$ at the $10 \%$-level. 
Furthermore Table 12 demonstrates that low human capital formation and diminished entrepreneurial spirit are indeed plausible mediating channels through which early industrial development has an adverse effect of the contemporary level of income per capita. Columns (1)-(4) report the IV regressions from Tables 7-10 for the effect of the horse power of steam engines on the share of men above 25 with a post-secondary degree, the shares of men age 15-17 and 18-24 enrolled in school as well as the probability that a secondgeneration migrant is self-employed or a business owner. Columns (5)-(9) report the mediating effects of these variables in IV regressions for the effect of the horse power of steam engines on income per capita in 2001-2005. The finding suggests that these variables are significantly correlated with log GDP per capita in 2001-2005 at the 1\% or 5\% level, and that accounting for their association with the level of income per capita, diminishes the effect of the horse power of steam engines on log GDP per capita in 2001-2005.

\subsubsection{Industrialization and Technological Inertia}

This subsection suggests that under-investment in human capital affected the contemporary composition of industries in historically industrial regions and reinforced the specialization in unskilled-intensive industries. In particular, it demonstrates that since the effect of early industrialization on acquired comparative advantage in the unskilled-intensive industrial sector depressed the demand for human capital and have triggered cultural inertia, characterized by a lower predisposition towards investment in human capital, this suboptimal level of human capital formation has further hindered the incentive of firms to adopt more lucrative skilled-intensive technologies, adversely effecting human capital formation and the standards of living in the long-run.

Table 13: Industrialization and Technological Inertia

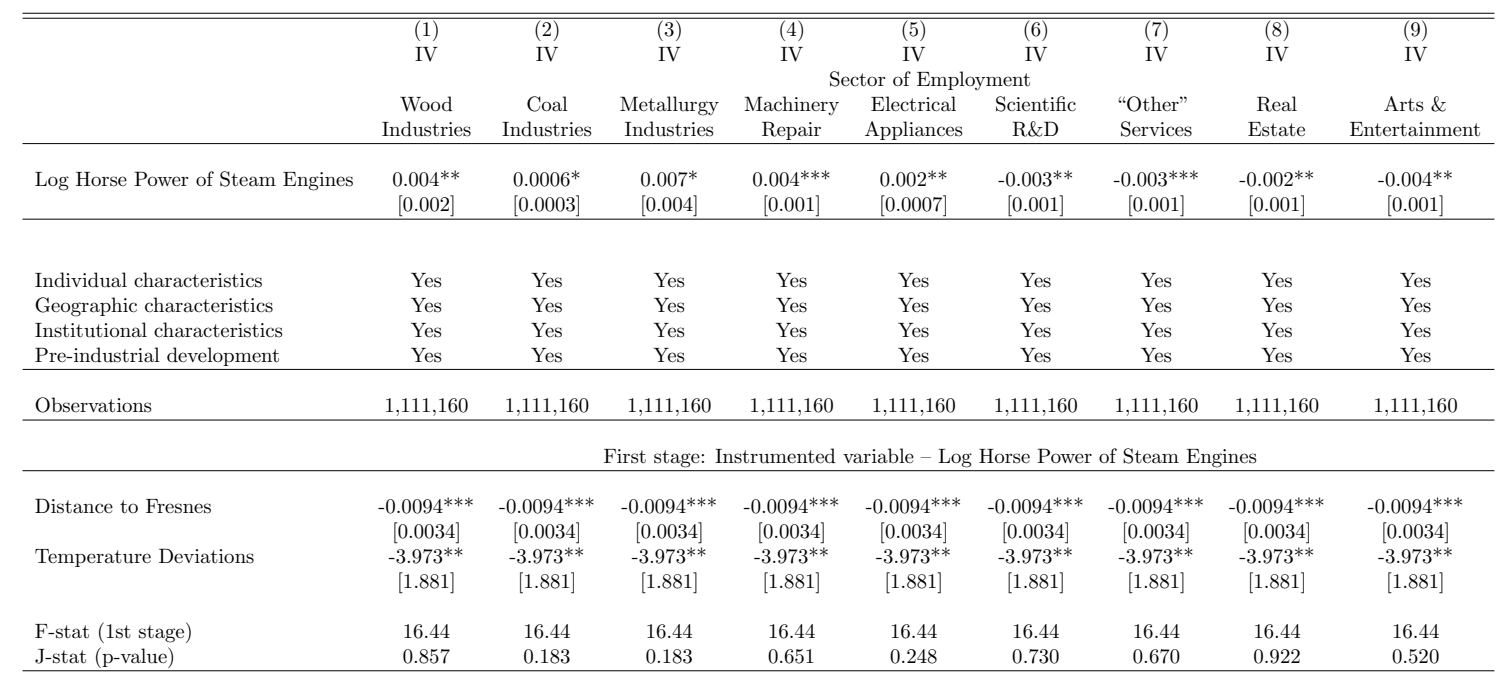

Notes: This table presents IV regressions relating the horse power of steam engines in 1860-1865 to the probability that private sector employees in 2008 work for firms in the following sectors: wood industries, coal industries, metallurgy, machinery repair, production \& distribution of electrical appliances, scientific R\&D, accommodation and catering, real Estate arts \& entertainment. Aerial distances are measured in kilometers. Other explanatory variables, except the dummies, and the dependent variables are in logarithm. Individual characteristics include the respondent's age and gender. Geographic characteristics include the department's latitude, land suitability, average rainfall and temperature, share of carboniferous area, distance to Paris as well as dummies for the presence of rivers and tributaries, maritime and border departments. Institutional measures include dummies for Alsace-Lorraine and for Paris and its suburbs. Pre-industrial development characteristics include a measure of the urban population in 1700. Heteroskedasticity-robust standard errors are reported in brackets. *** indicates significance at the $1 \%$-level, ** at the $5 \%$-level, $*$ at the $10 \%$-level.

The long-run negative effect of industrialization on the workforce is reflected in the types of firms which employ individuals. Using a 2008 governmental survey on 1.1 million employees age 35-64 from the private sector, Table 13 establishes that the horse power of steam engines in 1860-1865 has a negative and significant effect at the 5-\% level on the probability that private sector employees work in firms in the R\&D sector, as well as in service firms in accommodation \& catering, arts \& entertainment and real estate. but a 
positive and significant effect at the 5-\% level on the probability that they work in low-skilled firms in the coal, metallurgical, wood sector as well as in the production of electrical appliances and in machinery repair. As such, Table 13 confirms the basic thrust of the analysis that past industrialization has contributed to technological inertia and explains the continued predominance of low-skilled-intensive industries.

These results lend credence to the argument that historical industrial regions have experienced a technological lock-in effect. Namely, acquired comparative advantage in the unskilled-intensive sector in early stages of industrialization is associated with the relative dominance of unskilled intensive firms and occupations.

\subsection{Industrialization \& the Evolution of Sectoral Employment and Composition}

This subsection establishes that the adverse effect of earlier industrialization on long-run prosperity does not reflect a delay transition from the industrial to the service sector, but rather the lower skill-intensity of occupation in the service as well as the industrial sector in historically industrial regions.

As depicted in panel A of Figure 9 (based on the IV regressions in Tables C.2 and C.3 in the Appendix), an intensive use of the steam engine in 1860-1865 had a highly significant positive effect on the share of employment in the industrial sector in 1861, 1901, and 1930. This effect remains positive and highly significant in 1968, 1975, and 1982, but is insignificant in 1990 and 1999 and finally becomes significantly negative in 2010. Furthermore, as depicted in panel B of Figure 9 (based on the IV regressions in Tables C.2 and C.3 in the Appendix), an intensive use of the steam engine in 1860-1865 had a positive and significant effect on the share of employment in the service sector over the period. only in 1861, 1901, and 1930 but subsequently the effect is insignificant.

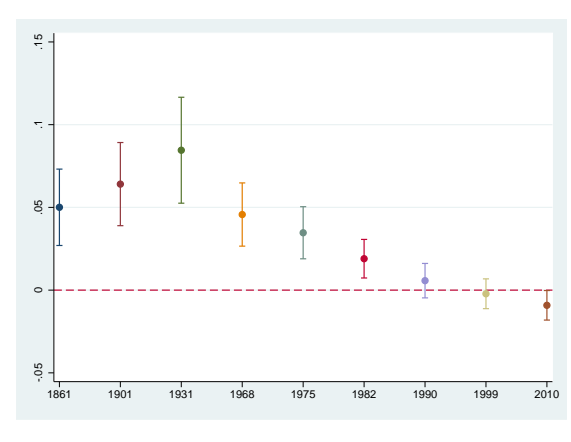

Panel A. The industrial sector.

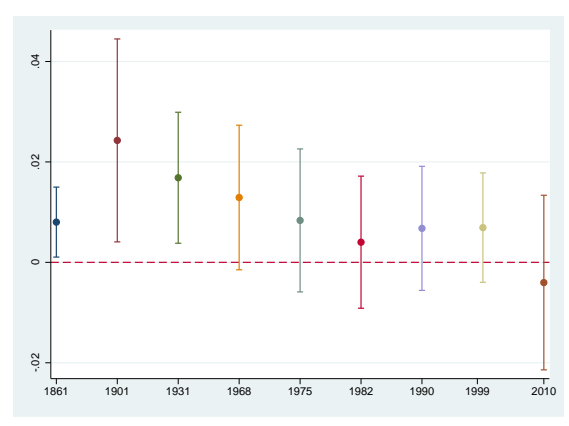

Panel B. The service sector.

Figure 9: The Effect of Horse Power of Steam Engines (1860-1865) on Sectoral Employment.

Note: Panel A: the estimated coefficients of Horse Power of Steam Engines on the share of the workforce in the industrial sector in the IV regressions in Tables C.1 and C.2. Panel B: the estimated coefficients of Horse Power of Steam Engines on the share of the workforce in the service sector in the IV regressions Tables C.3 and C.4. Intervals reflect 95\%-confidence levels.

The study further explores the effect of industrialization on the long-run composition of human capital as it is reflected in the workforce in each department. First, it focuses on the evolution in the shares of executives, middle management professions, and employees (i.e., individuals with high, medium, and low levels of human capital) in the labor force between 1968 and $2010 .{ }^{29}$ It demonstrates that industrialization had a detrimental effect on employment in skilled-intensive occupations, although industrialization had no effect on the share of employment in the service sector in the long-run. As depicted in Panels A-C of Figure 10 (based on the IV regressions in Tables C.5-C.7 in the Appendix), the horse power of steam engines in industrial production in 1860-1865 had a significantly negative effect on the share of executives and other intellectual professions as well as middle management professions among individuals age 25-54 in 2010. In contrast, the effect on the share of employees is positive and significant in 2010. Furthermore, these

\footnotetext{
${ }^{29}$ The control group is made of farmers, artisans and other self-employed individuals.
} 
contrasting effects have become more pronounced in the past few decades, suggesting that the technological lock-in effect has be intensified in the past decades as the prevalence skill-intensive technologies has intensified.

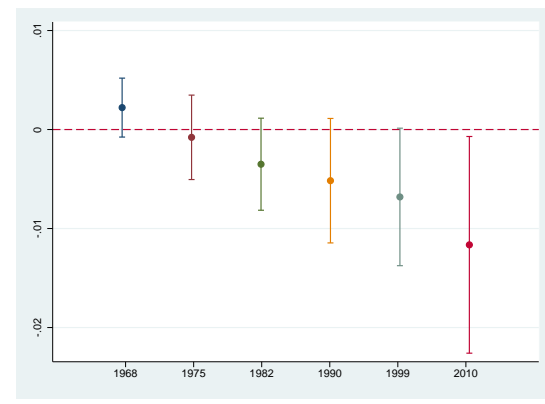

A. Executives in workforce.

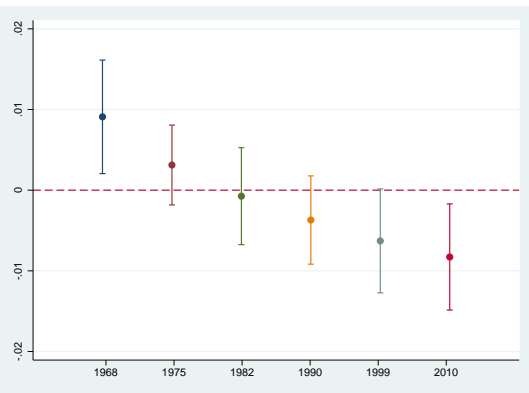

B. Intermediary professionals in workforce

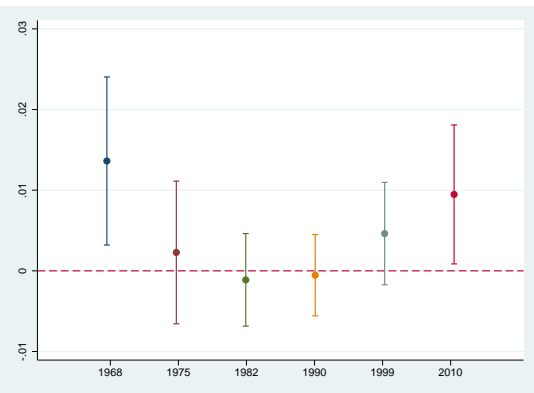

C. Employees in workforce,

Figure 10: The Effect of Horse Power of Steam Engines (1860-1865) on Occupational Choices Notes: This figure displays the estimated coefficients of Horse Power of Steam Engines in the IV regressions in Tables C.5 - C.7. Intervals reflect $95 \%$-confidence levels.

\subsection{Alternative Channels}

This section establishes that alternative plausible channels are inconsistent with the evidence. First, the labor market channel: the contribution of industrialization to unionization and wage rates in historically industrialized regions and the comparative decline of these regions in the long-run due to the incentive of modern industries to locate in regions where labor markets are more competitive. Second, the trade protection channel: the effect of trade protection on traditional industry on the decline in competitiveness of historically industrialized regions in the long-run. Third, the war destruction channel: the potential negative effect of disproportional destruction of industrialized regions during WWI and WWII on the subsequent development of these regions. Fourth, the migration channel: the persistent adverse effect of selective migration (e.g. immigration of unskilled workers into industrialized regions, or the emigration of more educated workers into less industrialized regions), on the composition of human capital and long-run income per capita in historically industrialized regions. Fifth, the public expenditure channel: the diversion of public investment in human capital towards non-industrial regions. Moreover, the empirical analysis demonstrates that the adverse effect of industrialization on long-run prosperity has not been mitigated by the positive effect of early industrialization on population density in historically industrialized regions and its potential beneficial effects via the spillover from agglomeration to long-run development.

\subsubsection{The Labor Market Channel}

The adverse effect of industrialization on income per capita in the long-run may reflect the adverse effect of industrialization on the competitiveness of the labor market in the long-run. In particular, the growth of the industrial sector may have led to the establishment of labor unions, which deterred new industries from locating in regions characterized by higher wages and possibly lower productivity. ${ }^{30}$

Indeed, as reported in Column (1) of Table 14, the degree of industrialization in the year 1860-1865 has no significant relationship with the share of unionized workers in the workforce in 1930. Moreover, as reported in Columns (2) and (3), the degree of unionization is, in fact, positively associated with the level income per capita in the long-run, and it does not have a qualitative impact on the estimated effect of industrialization on income per capita in the long-run. ${ }^{31}$

\footnotetext{
${ }^{30}$ Unions were given a legal status in France in 1884. It is worth noting that in France, unlike in the USA for instance, labor regulations are identical throughout the country. Nevertheless, unions could have negotiated higher salaries in specific firms.

${ }^{31}$ Since unionization is potentially endogenous to the adoption of the steam engine and we treat it as a "bad controls" to
} 
Table 14: Industrialization and Long-Run Prosperity: The Union Channel

\begin{tabular}{|c|c|c|c|}
\hline & $\begin{array}{c}(1) \\
\text { OLS } \\
\text { Log Unionized Workers (\%) } \\
1930 \\
\end{array}$ & $\begin{array}{c}(2) \\
\text { IV } \\
\text { Log GDP } \\
2001 \\
\end{array}$ & \begin{tabular}{l}
\multicolumn{1}{c}{$(3)$} \\
$\quad$ IV \\
per capita \\
2005
\end{tabular} \\
\hline $\begin{array}{l}\text { Log Horse Power of Steam Engines } \\
\text { Log Unionized Workers (\%) } 1930\end{array}$ & $\begin{array}{c}0.003 \\
{[0.044]}\end{array}$ & $\begin{array}{c}-0.060^{* * *} \\
{[0.022]}\end{array}$ & $\begin{array}{c}-0.058^{* * *} \\
{[0.021]} \\
0.099 * * \\
{[0.044]}\end{array}$ \\
\hline $\begin{array}{l}\text { Geographic characteristics } \\
\text { Institutional characteristics } \\
\text { Pre-industrial development }\end{array}$ & $\begin{array}{l}\text { Yes } \\
\text { Yes } \\
\text { Yes }\end{array}$ & $\begin{array}{l}\text { Yes } \\
\text { Yes } \\
\text { Yes }\end{array}$ & $\begin{array}{l}\text { Yes } \\
\text { Yes } \\
\text { Yes }\end{array}$ \\
\hline $\begin{array}{l}\text { Adjusted R2 } \\
\text { Observations }\end{array}$ & $\begin{array}{c}0.208 \\
89\end{array}$ & 89 & 89 \\
\hline \multicolumn{4}{|c|}{ First stage: Instrumented variable - Log Horse Power of Steam Engines } \\
\hline $\begin{array}{l}\text { Distance to Fresnes } \\
\text { Temperature Deviations }\end{array}$ & & $\begin{array}{c}-0.0075^{* * *} \\
{[0.0026]} \\
-4.254^{* *} \\
{[2.092]}\end{array}$ & $\begin{array}{c}-0.0075^{* * *} \\
{[0.0026]} \\
-4.254^{* *} \\
{[2.102]}\end{array}$ \\
\hline $\begin{array}{l}\text { F-stat (1st stage) } \\
\text { J-stat (p-value) }\end{array}$ & & $\begin{array}{l}13.64 \\
0.101 \\
\end{array}$ & $\begin{array}{l}13.67 \\
0.126\end{array}$ \\
\hline
\end{tabular}
Note: This table presents OLS and IV regressions to establish that the negative relationship between the horse power of steam engines in $1860-1865$ and log
GDP per capita in $2001-2005$ is robust to accounting for the past share of union workers (in 1930). All regressions include a dummy variable for the three departments which had no steam engine in 1860-1865. Aerial distances are measured in kilometers. Other explanatory variables, except the dummies, and the dependent variables are in logarithm. Geographic characteristics include the department's latitude, land suitability, average rainfall and temperature, share of carboniferous area, distance to Paris as well as dummies for the presence of rivers and tributaries, maritime and border departments. Institutional measures include dummies for Alsace-Lorraine and for Paris and its suburbs. Pre-industrial development characteristics include a measure of the urban population in 1700. Heteroskedasticity-robust standard errors are reported in brackets. * indicates significance at the $1 \%-l e v e l$,

Similarly, Column (1) of Table 15 suggests that the relation between industrialization in 1860-1865 and the average male wage in each department in 1901 is insignificant as well. Moreover, as reported in Columns (2) and (3), the average adult wage in 1901 is in fact positively related to income per capita in the long-run, and it does not have a qualitative impact on the estimated effect of industrialization on income per capita in the long-run. Thus, the adverse effect of industrialization on income per capita in the long-run cannot be attributed to the effect of labor unions and higher wages.

\subsubsection{The Trade and Environment Protection Channels}

This section explores whether the detrimental effect of industrialization on the standard of living in the longrun could be attributed to the adverse effect of trade protection on the competitiveness of each department in the long-run.

In light of the departmental variation in the composition of the 16 sectors that constituted the industrial sector in 1860-1865, the imposition of tariffs on import by the national government could have affected each department differentially. In particular, the degree of competitiveness in the most advanced industrial sectors could have diminished and may have thus led to their economic decline in the long-run. (As such, tariffs could be viewed as endogenous to the adoption of the steam engine and to account for their effects, they are treated as potential "bad controls".

account for its impact on income per capita. 
Table 15: Industrialization and Long-Run Prosperity: The Wage Channel

\begin{tabular}{|c|c|c|c|}
\hline & $\begin{array}{c}(1) \\
\text { OLS } \\
\text { Log Average Wage } \\
1901 \\
\end{array}$ & $\begin{array}{c}\text { (2) } \\
\text { IV } \\
\text { Log GDP } \\
2001\end{array}$ & $\begin{array}{l}\quad \text { (3) } \\
\text { IV } \\
\text { oer capita } \\
2005\end{array}$ \\
\hline $\begin{array}{l}\text { Log Horse Power of Steam Engines } \\
\text { Log Average Wage } 1901\end{array}$ & $\begin{array}{c}0.005 \\
{[0.013]}\end{array}$ & $\begin{array}{c}-0.060^{* * *} \\
{[0.022]}\end{array}$ & $\begin{array}{c}-0.071^{* * *} \\
{[0.025]} \\
0.268^{*} \\
{[0.145]}\end{array}$ \\
\hline $\begin{array}{l}\text { Geographic characteristics } \\
\text { Institutional characteristics } \\
\text { Pre-industrial development }\end{array}$ & $\begin{array}{l}\text { Yes } \\
\text { Yes } \\
\text { Yes }\end{array}$ & $\begin{array}{l}\text { Yes } \\
\text { Yes } \\
\text { Yes }\end{array}$ & $\begin{array}{l}\text { Yes } \\
\text { Yes } \\
\text { Yes }\end{array}$ \\
\hline $\begin{array}{l}\text { Adjusted R2 } \\
\text { Observations }\end{array}$ & $\begin{array}{c}0.523 \\
85\end{array}$ & 89 & 85 \\
\hline
\end{tabular}

First stage: Instrumented variable - Log Horse Power of Steam Engines

\begin{tabular}{lcc} 
Distance to Fresnes & $-0.0075^{* * *}$ & $-0.0078^{* * *}$ \\
& {$[0.0026]$} & {$[0.0026]$} \\
Temperature Deviations & $-4.254^{* *}$ & $-4.257^{*}$ \\
& {$[2.092]$} & {$[2.366]$} \\
& & \\
F-stat & 13.64 & 14.26 \\
J-stat (p-value) & 0.101 & 0.193 \\
\hline
\end{tabular}

Note: This table presents OLS and IV regressions to establish that the negative relationship between the horse power of steam engines in $1860-1865$ and $\log$ GDP per capita in 2001-2005 is robust to accounting for the past average wage (in 1901). All regressions include a dummy variable for the three departments which share of carboniferous area, distance to Paris as well as dummies for the presence of rivers and tributaries, maritime and border departments. Institutional measures include dummies for Alsace-Lorraine and for Paris and its suburbs. Pre-industrial development characteristics include a measure of the urban population in 1700 . Heteroskedasticity-robust standard errors are reported in brackets. *** indicates significance at the $1 \%-l$ evel, $* *$ at the $5 \%-l$ level, $*$ at the $10 \%$-level.

Table 16: Industrialization and Long-Run prosperity: The Trade Protection Channel

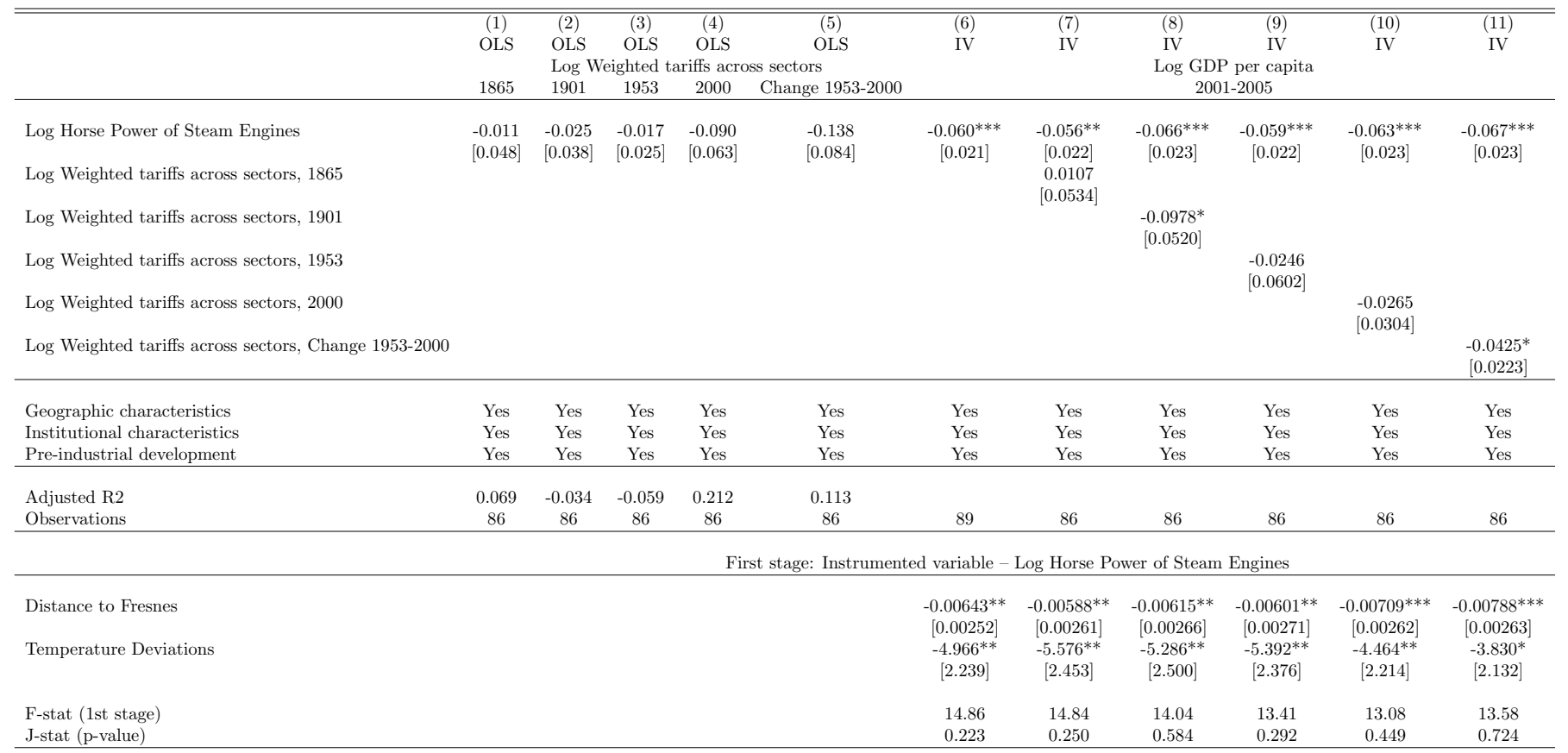

Note: This table presents OLS and IV regressions to establish that the negative relationship between the horse power of steam engines in $1860-1865$ and $\log$ GDP per capita in 2001-2005 is robust to accounting for tariffs in 1865, 1901, 1953 and 2000. All regressions include a dummy variable for the three departments which had no steam engine in 1860-1865. Aerial distances are measured in kilometers. Other explanatory variables, except the dummies, and the dependent variables are in logarithm. Geographic characteristics include the department's latitude, land suitability, average rainfall and temperature, share of carboniferous area, distance to Paris as well as dummies for the presence of rivers and tributaries, maritime and border departments. Institutional measures include dummies for Alsace-Lorraine and for Paris and its suburbs. Pre-industrial development characteristics include a measure of the urban population in 1700 . Heteroskedasticity-robust standard errors are reported in brackets. *** indicates significance at the $1 \%$-level, $* *$ at the $5 \%$-level, $*$ at the $10 \%$-level 
Nevertheless, as reported in Table 16 intensive industrialization in the 1860-1865 period is unrelated to the weighted tariffs across sectors in 1865, 1901, 1953 (just before the signature of the 1957 Treaty of Rome which founded the European Union) and 2000. ${ }^{32}$ Moreover, tariff rates in the years 1865, 1901, 1953 and 2000 had a negative but mostly insignificant association with income per capita in 2001-2005. ${ }^{33}$ Furthermore, tariff does not have a qualitative impact on the estimated effect of industrialization on income per capita in the long-run. Thus, the adverse effect of industrialization on income per capita in the long-run cannot be attributed to the effect of industrialization on trade protection.

Moreover, since environmental regulation is sometimes associated with industrial protection, we investigate whether restrictions on $\mathrm{CO} 2$ emissions had an effect on income per capita. In particular, the directives of the European Union compelled the French government to decrease quotas on $\mathrm{CO} 2$ emissions and might have entailed a decline in competitiveness of polluting industries (e.g., mining) which led development in the 19th century. For this purpose, we collect governmental data on actual levels of CO2 emissions in 2005 and compute the ratio of quotas on $\mathrm{CO} 2$ emissions in 2012 to actual levels in 2005 in each department. The OLS regressions in Columns (1) and (2) of Table F.3 establish that the horse power of steam engines in 1860-1865 is positively and significantly correlated with $\mathrm{CO} 2$ emission levels in 2005 but not with the ratio of quotas on CO2 emissions in 2012 to actual levels in 2005. Furthermore, the inclusion of these two variables in the IV regressions in Columns (3)-(5) of Table F.3 does not modify the negative and significant impact of the horse power of steam engines on income per capita in 2001-2005. As such, it appears that environmental regulation does not explain the negative impact of 19th century industrialization on present income.

\subsubsection{The War Destruction Channel}

World War I and World War II, and the associated destruction of physical capital, may have affected disproportionately industrial centers, potentially leading to their decline in the long-run. Nevertheless, accounting for the destruction of physical capital does not affect the qualitative results. ${ }^{34}$

While the physical destruction in industrial intensive departments was indeed larger in WWI, according to Column (1) of Table 17, it had no impact on the adverse effect of industrialization and income per capita in 2001-2005. Since the battlefields during WWI were in the Northern and Eastern parts of France, destruction of buildings during WWI is highly correlated with the distance from Fresnes-sur-Escaut. Consequently, the diminished effect of industrialization on income per capita in the contemporary period, as reported in column (4) of Table 17, partly reflects the decline in the power of the instrumental variables below the desirable threshold of 10. However, accounting for the number of buildings destroyed in each department in WWII, the destruction of physical capital in this war has no qualitative impact on the effect of industrialization on income per capita in 2001-2005 (Columns (3)-(5) of Table 17).

\footnotetext{
${ }^{32}$ This pattern may reflect the fact that tariffs in the early period were also levied on agricultural products and the protection of industrial departments was not eventually different from departments that remained agricultural (Crouzet, 2003).

${ }^{33}$ As reported in Table F.2 in the Appendix, there is no significant relationship between tariff and income per capita in the years 1860, 1901, and 1930 and the tariff rate in the past has neither an economic impact nor a statistical one on the effect of industrialization on income per capita in 1860, 1901 and 1930. There is no effect of the tariff rate in 1970 and 1990 on income per capita in 2001-2005

${ }^{34}$ Available data on destruction of human capital during the war is restricted to the death of soldiers rather than civilians. Moreover, soldier deaths are classified based on the department of origin of each soldier, rather than on the place where the death took place. In this respect, disproportionate destruction of human capital in industrial departments will not be reflected in the data and thus cannot be used to reaffirmed the results based on the destruction of physical capital.
} 
Table 17: Industrialization \& income per capita, accounting for the destruction of buildings in the World Wars

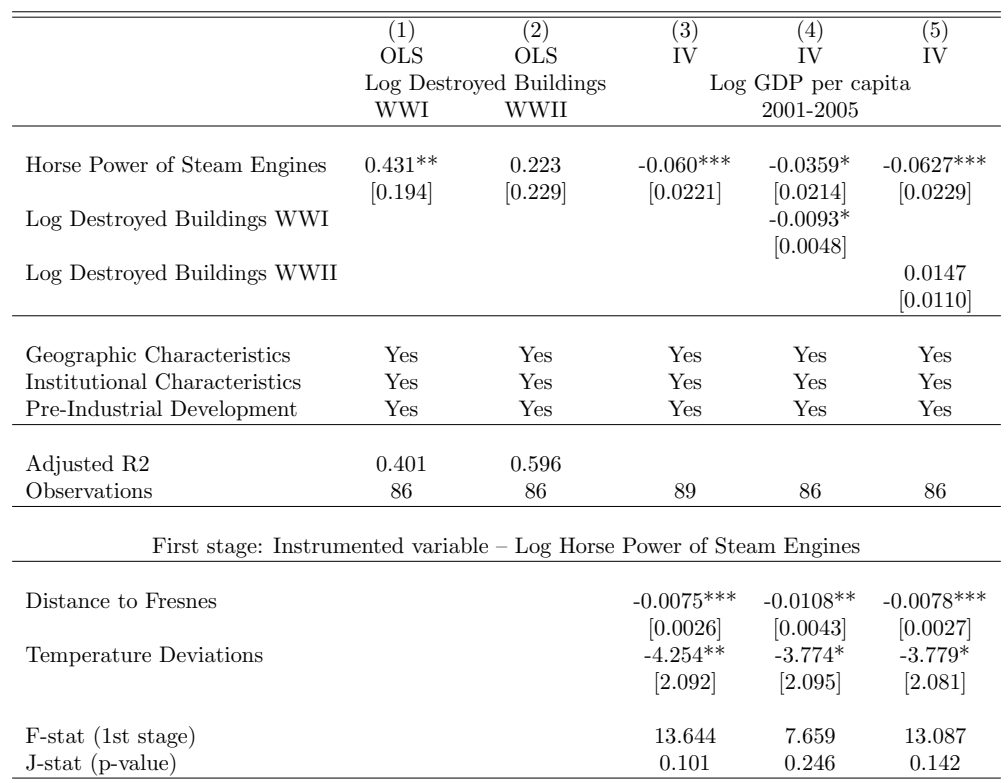

Notes: This table presents OLS and IV regressions to establish that the negative relationship between the horse power of steam engines in $1860-1865$ and $\log$ GDP per capita in 2001-2005 is robust to accounting for building destruction in WWI and WWII. All regressions include a dummy variable for the three departments which had no steam engine in 1860-1865. Aerial distances are measured in kilometers. Other explanatory variables, except the dummies, and the dependent variables are in logarithm. Geographic characteristics include the department's latitude, land suitability, average rainfall and temperature, share of carboniferous area, distance to Paris as well as dummies for the presence of rivers and tributaries, maritime and border departments. Institutional measures include dummies for Alsace-Lorraine and for Paris and its suburbs. Pre-industrial development characteristics include a measure of the urban population in 1700 . Robust standard errors are reported in brackets. *** indicates significance at the $1 \%$-level, ** at the $5 \%$-level, * at the $10 \%$-level.

\subsubsection{The Migration Channel}

The persistent adverse effect of selective migration (e.g. immigration of unskilled workers into industrialized regions or emigration of more educated workers into less industrialized regions) on the composition of human capital could have been associated with the adverse effect of early industrialization on the long-run level of income per capita in these regions.

However, as reported in Table 18 there is no significant correlation between the horse power of steam engines in 1860-1865 and the share of natives in the population of each department in 1901 and $2010 .^{35}$ Moreover, accounting for the share of the native population in each department in 1901 and 2001-2005 does not substantially affect the negative effect of industrialization on income per capita in the 2001-2005 period becomes highly significant. Moreover, since migration flows are likely to be towards more prosperous departments, a higher percentage of natives in the departmental population is indicative of a less attractive migration destination, and indeed in both time periods higher percentage of native population is associated with lower income per capita (Columns (2) and (4)), although the relationship is not significant in the modern period.

${ }^{35}$ The 1860 and 1931 censuses do not provide information on the native population in each department. 
Table 18: Industrialization and Long-Run Prosperity: The Migration Channel

\begin{tabular}{|c|c|c|c|c|c|}
\hline & & & $\begin{array}{l}(3) \\
\text { IV }\end{array}$ & $\begin{array}{l}\text { (4) } \\
\text { IV }\end{array}$ & $\begin{array}{l}(5) \\
\text { IV }\end{array}$ \\
\hline & \multicolumn{2}{|c|}{ Log Share of native population } & \multicolumn{3}{|c|}{ Log GDP per cap6ita } \\
\hline & 1901 & 2010 & & $2001-2005$ & \\
\hline Log Horse Power of Steam Engines & -0.006 & 0.008 & $-0.060^{* * *}$ & $-0.075^{* * *}$ & $-0.056^{* * *}$ \\
\hline Log Share of the native population 1901 & & & & $\begin{array}{c}-0.884^{* * *} * \\
{[0.254]}\end{array}$ & \\
\hline Log Share of the native population 2010 & & & & & $\begin{array}{l}-0.026 \\
{[0.253]}\end{array}$ \\
\hline Geographic characteristics & Yes & Yes & Yes & Yes & Yes \\
\hline Institutional characteristics & Yes & Yes & Yes & Yes & Yes \\
\hline Pre-industrial development & Yes & Yes & Yes & Yes & Yes \\
\hline Adjusted R2 & 0.567 & 0.624 & & & \\
\hline Observations & 87 & 89 & 89 & 87 & 89 \\
\hline
\end{tabular}

First stage: Instrumented variable - Log Horse Power of Steam Engines

\begin{tabular}{lccc} 
Distance to Fresnes & $-0.0075^{* * *}$ & $-0.0071^{* *}$ & $-0.0061^{* *}$ \\
Temperature Deviations & {$[0.0026]$} & {$[0.0028]$} & {$[0.0028]$} \\
& $-4.254^{* *}$ & $-4.292^{*}$ & $-5.210^{* *}$ \\
& {$[2.092]$} & {$[2.243]$} & {$[2.289]$} \\
F-stat (1st stage) & & & \\
J-stat (p-value) & 13.64 & 12.80 & 14.24 \\
\hline
\end{tabular}

Note: This table presents OLS and IV regressions to establish that the negative relationship between the horse power of steam engines in $1860-1865$ and $\log$ GDP per capita in 2001-2005 is robust to the share of the native population in 1901 and 2000 . All regressions include a dummy variable for the three departments which had no steam engine in 1860-1865. Aerial distances are measured in kilometers. Other explanatory variables, except the dummies, and the dependent variables are in logarithm. Geographic characteristics include the department's latitude, land suitability, average rainfall and temperature, share of carboniferous area, distance to Paris as well as dummies for the presence of rivers and tributaries, maritime and border departments. Institutional measures include dummies for Alsace-Lorraine and for Paris and its suburbs. Pre-industrial development characteristics include a measure of the urban population in 1700. Heteroskedasticity-robust standard errors are reported in brackets. *** indicates significance at the $1 \%$-level, ** $5 \%$-level, * $10 \%$-level.

Table 19: Industrialization and Long-Run Prosperity: The Public Expenditure Channel

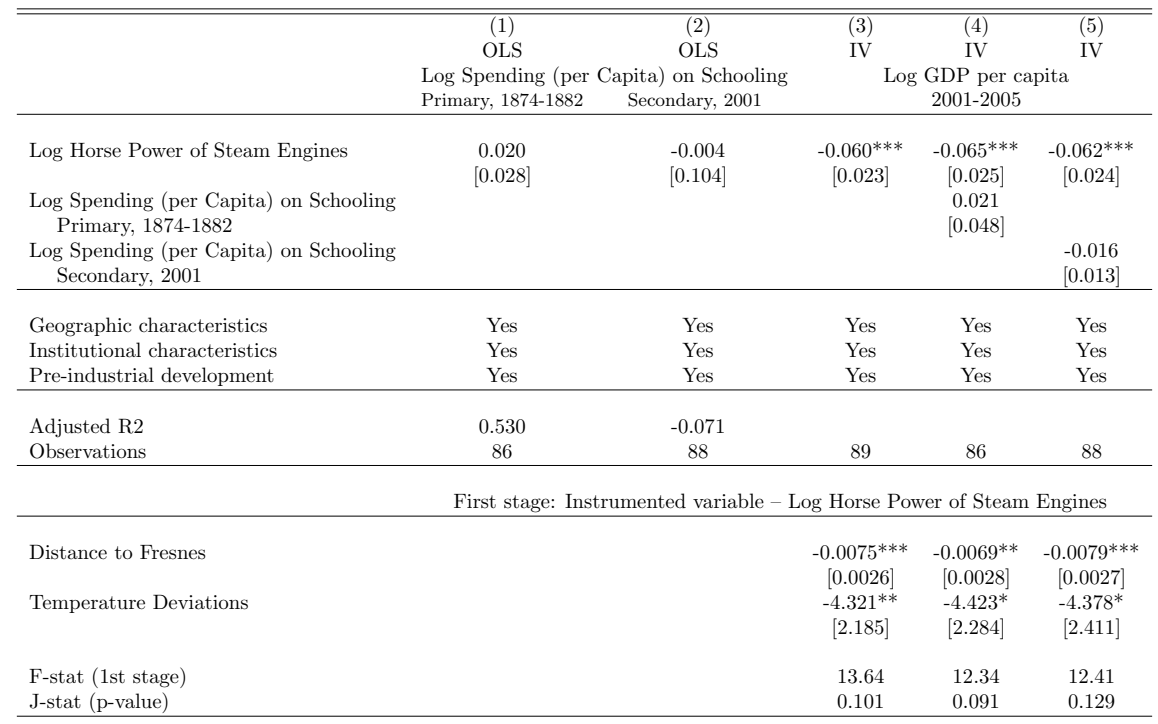

Note: This table presents OLS and IV regressions establishing that the negative relationship between the horse power of steam engines in $1860-1865$ and $\log$ GDP per capita in 2001-2005 is robust to accounting for public spending on schooling in 1874-1882 (primary) and 2001 (secondary). Aerial distances are measured in kilometers. Other explanatory variables, except the dummies, and the dependent variables are in logarithm. Geographic characteristics include the department's latitude, land suitability, average rainfall and temperature, share of carboniferous area, distance to Paris as well as dummies for the presence of rivers and tributaries, maritime and border departments. Institutional measures include dummies for Alsace-Lorraine and for Paris and its suburbs. Pre-industrial development characteristics include a measure of the urban population in 1700. Heteroskedasticity-robust standard errors are reported in brackets. *** indicates significance at the $1 \%$-level, ** $5 \%$-level, * $10 \%$-level. 


\subsubsection{The Public Expenditure Channel}

However, as reported in Tables 19 and D.4, there is no significant correlation between the horse power of steam engines in 1860-1865 and the departmental governments' spending on education per capita in the late 19 th century and at the turn of the 21st century. Moreover, does not qualitatively affect the negative and significant impact of 19th century industrialization on log GDP per capita in 2001-2005.

The diversion of public investment in human capital towards non-industrial regions, could have contributed to the negative impact of intensive industrialization in the past on long-run prosperity

\subsubsection{The Agglomeration Channel}

The empirical analysis further demonstrates that the adverse effect of industrialization on long-run prosperity has not been mitigated by the positive effect of early industrialization on population density in historically industrialized regions and its potential beneficial effects via the spillover from agglomeration to long-run development.

As reported in Tables 20 and E.1, past levels of population in each department and in each department's chef-lieu (i.e., its administrative capital), are not associated with the horse power of steam engines in the 1860-1865 period. Moreover, while the scale of the population is correlated with income per capita in 20012005 , the adverse effect of the horse power of steam engines in 1860-1865 on income per capita in 2001-2005 remains highly significant.

Table 20: Industrialization and Long-Run Prosperity: The Agglomeration Channel

\begin{tabular}{|c|c|c|c|c|c|c|c|}
\hline & $\begin{array}{l}\text { (1) } \\
\text { IV }\end{array}$ & $\begin{array}{l}\text { (2) } \\
\text { IV }\end{array}$ & $\begin{array}{l}(3) \\
\text { IV }\end{array}$ & $\begin{array}{l}\text { (4) } \\
\text { IV }\end{array}$ & $\begin{array}{l}\text { (5) } \\
\text { IV }\end{array}$ & $\begin{array}{l}\text { (6) } \\
\text { IV }\end{array}$ & $\begin{array}{l}\text { (7) } \\
\text { IV }\end{array}$ \\
\hline & \multicolumn{3}{|c|}{ Log Population } & \multirow{2}{*}{\multicolumn{4}{|c|}{$\begin{array}{c}\text { Log GDP per capita } \\
2001-2005\end{array}$}} \\
\hline & 1901 & 1921 & 2010 & & & & \\
\hline Horse Power of Steam Engines & $\begin{array}{l}-0.044 \\
{[0.061]}\end{array}$ & $\begin{array}{l}-0.005 \\
{[0.054]}\end{array}$ & $\begin{array}{l}-0.071 \\
{[0.078]}\end{array}$ & $\begin{array}{c}-0.060^{* * *} \\
{[0.022]}\end{array}$ & $\begin{array}{c}-0.042^{* *} \\
{[0.018]}\end{array}$ & $\begin{array}{c}-0.047^{* *} \\
{[0.019]}\end{array}$ & $\begin{array}{c}-0.044^{* *} \\
{[0.018]}\end{array}$ \\
\hline Log Population 1901 & & & & & $\begin{array}{c}0.227^{* * * *} \\
{[0.053]}\end{array}$ & & \\
\hline Log Population 1921 & & & & & & $\begin{array}{c}0.224^{* * *} \\
{[0.048]}\end{array}$ & \\
\hline Log Population 2010 & & & & & & & $\begin{array}{c}0.170^{* * *} \\
{[0.028]}\end{array}$ \\
\hline Geographic characteristics & Yes & Yes & Yes & Yes & Yes & Yes & Yes \\
\hline Institutional characteristics & Yes & Yes & Yes & Yes & Yes & Yes & Yes \\
\hline Pre-industrial development & Yes & Yes & Yes & Yes & Yes & Yes & Yes \\
\hline \multirow[t]{2}{*}{ Observations } & 87 & 89 & 89 & 89 & 87 & 89 & 89 \\
\hline & \multicolumn{7}{|c|}{ First stage: Instrumented variable - Log Horse Power of Steam Engines } \\
\hline Distance to Fresnes & $\begin{array}{c}-0.0069^{* *} \\
{[0.0026]}\end{array}$ & $\begin{array}{c}-0.0073^{* * *} \\
{[0.0026]}\end{array}$ & $\begin{array}{c}-0.0073^{* * *} \\
{[0.0026]}\end{array}$ & $\begin{array}{c}-0.0075^{* * *} \\
{[0.0026]}\end{array}$ & $\begin{array}{l}-0.0039 \\
{[0.0026]}\end{array}$ & $\begin{array}{c}-0.0048^{*} \\
{[0.0027]}\end{array}$ & $\begin{array}{c}-0.0075 * * * \\
{[0.0027]}\end{array}$ \\
\hline Temperature Deviations & $\begin{array}{c}-4.569^{* *} \\
{[2.111]}\end{array}$ & $\begin{array}{c}-4.484^{* *} \\
{[1.995]}\end{array}$ & $\begin{array}{c}-4.484^{* *} \\
{[1.995]}\end{array}$ & $\begin{array}{c}-4.254^{* *} \\
{[2.092]}\end{array}$ & $\begin{array}{c}-6.099 * * * \\
{[1.874]}\end{array}$ & $\begin{array}{c}-5.791 * * * \\
{[1.885]}\end{array}$ & $\begin{array}{c}-5.027^{* *} \\
{[1.941]}\end{array}$ \\
\hline F-stat (1st stage) & 13.27 & 14.34 & 14.34 & 13.64 & 14.03 & 14.87 & 15.80 \\
\hline J-stat (p-value) & 0.039 & 0.118 & 0.806 & 0.101 & & 0.029 & 0.072 \\
\hline
\end{tabular}

Note: This table presents OLS and IV regressions to establish that the negative relationship between the horse power of steam engines in $1860-1865$ and log GDP per capita in 2001-2005 is robust to accounting for department population in 1901, 1931 and 2010. All regressions include a dummy variable for the three departments which had no steam engine in 1860-1865. Aerial distances are measured in kilometers. Other explanatory variables, except the dummies, and the dependent variables are in logarithm. Geographic characteristics include the department's latitude, land suitability, average rainfall and temperature, share of carboniferous area, distance to Paris as well as dummies for the presence of rivers and tributaries, maritime and border departments. Institutional measures include dummies for Alsace-Lorraine and for Paris and its suburbs. Pre-industrial development characteristics include a measure of the urban population in 1700 . Heteroskedasticity-robust standard errors are reported in brackets. *** indicates significance at the $1 \%-l e v e l, * *$ at the $5 \%$-level, * at the $10 \%$-level. 


\section{Concluding Remarks}

This research explores the long-run effect of industrialization on the process of development. In contrast to conventional wisdom that views industrial development as a catalyst for economic growth, highlighting its persistent effect on economic prosperity, the study establishes that while the adoption of industrial technology was initially conducive for economic development, it has had a detrimental effect on standards of living in the long-run.

The study exploits exogenous source of regional variation in the adoption of steam engines during the French industrial revolution to establish that regions which industrialized more intensively experienced an increase in literacy rates more swiftly and generated higher income per capita in the subsequent decades. Nevertheless, industrialization had an adverse effect on income per capita by the turn of the $21^{\text {st }}$ century.

The research further explores the mediating channels through which earlier industrial development has an adverse effect of the contemporary level of development. It suggests that the adverse effect of industrialization on long-run prosperity reflects the adverse effect of earlier specialization in unskilled-intensive industries on human capital formation and the incentive to adopt skill-intensive technologies in the contemporary era. Industrialization has triggered a dual techno-cultural lock-in effect characterized by a reinforcing interaction between technological inertia, reflected by the persistence predominance of low-skilled-intensive industries and cultural inertia, in the form of a lower predisposition towards investment in human capital. In particular, while the adoption of industrial technology was conducive for economic development in the short-run, acquired comparative advantage in the unskilled-intensive industrial sector had triggered cultural inertia, characterized by lower educational aspirations, that has hindered the transition to more lucrative skilled-intensive sectors, adversely effecting human capital formation and the standards of living in the long-run.

The study suggests that the characteristics that permitted the onset of industrialization, rather than the adoption of industrial technology per se, may have been the source of prosperity among the currently developed economies that experienced an early industrialization. Moreover the study highlights the existence of an intertemporal trade-off associated with industrialization. It suggests that developing countries may benefit from the allocation of resources towards human capital formation and skill-intensive sectors rather than toward the development of an unskilled-intensive industrial sector. 


\section{References}

Acemoglu, Daron, Simon Johnson and James A. Robinson (2001), 'The colonial origins of comparative development: An empirical investigation', The American Economic Review 91(5), 1369-1401.

Aghion, Philippe, Ufuk Akcigit, Matthieu Lequien and Stefanie Stantcheva (2017), Do entrepreneurship and selfemployment respond to simpler fiscal incentives? Evidence from France. Working Paper.

Andersen, Thomas B., Carl-Johan Dalgaard and Pablo Selaya (2016), 'Climate and the emergence of global income difference', Review of Economic Studies 83, 1334-1363.

Annuaire Statistique De La France (1878-1939), Imprimerie Nationale, Paris.

Ashraf, Qamrul and Oded Galor (2013), 'The out of Africa hypothesis, human genetic diversity, and comparative economic development', American Economic Review 103(1), 1-46.

Ballot, Charles (1923), L'Introduction du Machinisme dans l'Industrie Française, Slatkine Reprints (1978), Geneva.

Baten, Jörg (2000), 'Heights and real wages in the 18th and 19th centuries: an international overview', Economic History Yearbook 41(41), 61-76.

Bresnahan, Timothy F. and Manuel Trajtenberg (1995), 'General purpose technologies: engines of growth?', Journal of Econometrics 65(1), 83-108.

Caron, François (1997), Histoire des chemins de fer en France: 1740-1883, Fayard, Paris.

Cervellati, Matteo and Uwe Sunde (2005), 'Human capital formation, life expectancy, and the process of development', American Economic Review 95(5), 1653-1672.

Crafts, Nicholas (2004), 'Steam as a general purpose technology: a growth accounting perspective', Economic Journal 114(495), 338-351.

Crouzet, François (2003), 'The historiography of French economic growth in the nineteenth century', Economic History Review 62(2), 215-242.

Dalgaard, Carl-Johan and Holger Strulik (2016), 'Physiology and development: why the West is taller than the rest', Economic Journal 126(598), 2292-2323.

Daudin, Guillaume (2010), 'Domestic trade and market size in late eighteenth-century France', Journal of Economic History $\mathbf{7 0}(3), 716-743$.

Dickinson, Henry Winram (1939), A short history of the steam engine, Cambridge University Press, Cambridge, UK. Donaldson, Dave (2015), 'The gains from market integration', Annual Review of Economics 7, 619-647.

Forest de Bélidor, Bernard (1737), Architecture hydraulique, ou l'art de conduire, d'élever et de ménager les eaux pour les différens besoins de la vie, Libraire de l'Artillerie et du Génie, Paris, France.

France, Direction de la Documentation Française (1995), Restaurer, réformer, agir : la France en 1945, Textes rassemblés par Patrice Liquière, La Documentation Française, Paris, France.

France. Ministère du travail et de la prévoyance sociale (1911), Statistique générale. Salaires et coût de l'existence: à diverses époques, jusqu'en 1910, Imprimerie Nationale, Paris.

Franck, Raphaël and Oded Galor (2017), Technology-skill complementarity in early phases of industrialization, Working Paper 23197, NBER.

Furet, François and Jacques Ozouf (1977), Lire et écrire. L'alphabétisation des Français de Calvin à Jules Ferry, Editions de Minuit, Paris, France.

Galor, Oded (2011), Unified Growth Theory, Princeton University Press, Princeton, NJ.

Galor, Oded and Omer Moav (2006), 'Das Human-Kapital: a theory of the demise of class structure', Review of Economic Studies 73, 85-117.

Galor, Oded and Ömer Özak (2016), 'The agricultural origins of time preference', American Economic Review 106(10), 3064-3103.

Grew, Raymond and Patrick J. Harrigan (1991), School, State, and Society: The Growth of Elementary Schooling in 
Nineteenth-Century France-A Quantitative Analysis, University of Michigan Press, Ann Arbor, MI.

Komlos, John (2005), 'Height of French soldiers, 1716-1784', ICPSR - Computer File 04363-v1.

Léon, Pierre (1976), L'affermissement du phénomène d'industrialisation, in F.Braudel and E.Labrousse, eds, 'Histoire économique et sociale de la France, vol. 3', PUF, Paris, pp. 475-616.

Litina, Anastasia (2016), 'Natural land productivity, cooperation and comparative development', Journal of Economic Growth 21(4), 351-408.

Lord, John (1923), Capital and steam power, 1750-1800, P.S. King, London, UK.

Luterbacher, Jürg, Daniel Dietrich, Elena Xoplaki, Martin Grosjean and Heinz Wanner (2004), 'European seasonal and annual temperature variability, trends, and extremes since 1500', Science 303(5663), 1499-1503.

Luterbacher, Jürg, Daniel Dietrich, Elena Xoplaki, Martin Grosjean and Heinz Wanner (2006), 'European seasonal temperature reconstructions', IGBP PAGES/World Data Center for Paleoclimatology Data Contribution Series No. 2006-060, NOAA/NCDC Paleoclimatology Program .

Mokyr, Joel (1990), The Lever of Riches, Oxford University Press, Oxford, U.K.

Mokyr, Joel (2016), A culture of growth: the origins of the modern economy, Princeton University Press, Princeton, New Jersey.

Nelson, Richard R. and Edmund S. Phelps (1966), 'Investment in humans, technological diffusion, and economic growth', American Economic Review 56(1-2), 69-75.

Özak, Omer (2010), The voyage of homo-oeconomicus: some economic measures of distance. Brown University Mimeo.

Pauling, Andreas, Jürg Luterbacher, Carlo Casty and Heiz Wanner (2006), 'Five hundred years of gridded highresolution precipitation reconstructions over Europe and the connection to large-scale circulation', Climate Dynamics 26, 387-405.

Ramankutty, Navin, Jonathan A. Foley, John Norman and Kevin McSweeney (2002), 'The global distribution of cultivable lands: current patterns and sensitivity to possible climate change', Global Ecology and Biogeography 11(5), 377392 .

Rosenberg, Nathan and Manuel Trajtenberg (2004), 'A general purpose technology at work: the Corliss steam engine in the late nineteenth-century United States', Journal of Economic History 64(1), 1-39.

Sée, Henri (1925), La vie économique de la France sous la Monarchie Censitaire (1815-1848), Librairie Félix Alcan, Paris.

Weber, Max (1930), The Protestant Ethic and the Spirit of Capitalism, Allen and Unwin, London, U.K. 


\section{Online Appendix}

Appendix A. Descriptive Statistics

Table A.1: Descriptive statistics

\begin{tabular}{|c|c|c|c|c|c|}
\hline & Obss & 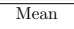 & Std. Dev. & 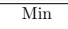 & 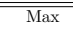 \\
\hline \multicolumn{6}{|l|}{$\begin{array}{l}\text { Dependent Variables } \\
\text { Income }\end{array}$} \\
\hline & 87 & 498.18 & 144.20 & 273 & 1105 \\
\hline GDP per capita, 1901 & 85 & 862.91 & & 255.30 & 1816.40 \\
\hline GDP per capita, 1930 & 87 & 6464.61 & 1500.21 & 4033.47 & 14109.92 \\
\hline \multirow{2}{*}{\multicolumn{6}{|c|}{ Workforce, Pre-WWII }} \\
\hline & & & & & \\
\hline $\begin{array}{l}\text { Share of Workforce in Industry, } 1861 \\
\text { Singe }\end{array}$ & 89 & 0.28 & 0.11 & 0.10 & 0.63 \\
\hline & 87 & 0.27 & 0.10 & 0.10 & 0.57 \\
\hline $\begin{array}{l}\text { Share of Workforce in Industry, } 1930 \\
\text { Share of Workforce in Services, } 1861\end{array}$ & $\begin{array}{l}89 \\
89\end{array}$ & 0.33 & 0.13 & 0.12 & 0.66 \\
\hline $\begin{array}{l}\text { Share of Worrtorce in Services, }, 8861 \\
\text { Share of Workforce in Services, } 1901\end{array}$ & $\begin{array}{l}89 \\
87\end{array}$ & $\begin{array}{l}0.024 \\
0.24\end{array}$ & $\begin{array}{l}0.02 \\
0.08\end{array}$ & 0.022 & 0.16 \\
\hline Share of Workforce in Services, 1930 & 89 & $\begin{array}{l}0.24 \\
0.21\end{array}$ & $\begin{array}{l}0.08 \\
0.06\end{array}$ & 0.12 & $\begin{array}{l}0.53 \\
0.47\end{array}$ \\
\hline \multicolumn{6}{|l|}{$\begin{array}{l}\text { Share of Worktorce in Services, } 1930 \\
\text { Workforce, Post-WWII } \\
\text { Share for Worfforce in Industry }\end{array}$} \\
\hline & 89 & 0.37 & 0.09 & 0.18 & 0.55 \\
\hline Share of Workforce in Industry, 1975 & 89 & 0.36 & 0.08 & 0.18 & 0.55 \\
\hline Share of Workforce in Industry, 1982 & 89 & 0.34 & 0.07 & 0.20 & 0.49 \\
\hline Share of Workforce in Industry, 1990 & & 0.31 & 0.06 & 0.15 & 0.44 \\
\hline Share of Workforce in Industry, 1999 & 89 & 0.26 & 0.06 & 0.14 & 0.36 \\
\hline Share of Workforce in Industry, 2010 & 89 & 0.23 & 0.03 & 0.14 & 0.33 \\
\hline Share of Workforce in Services, 1968 & 89 & 0.40 & 0.07 & 0.28 & 0.60 \\
\hline $\begin{array}{l}\text { Share of Workforce in Services, } 1975 \\
\text { Saf }\end{array}$ & 89 & 0.46 & 0.07 & 0.33 & 0.65 \\
\hline $\begin{array}{l}\text { Share of Workforce in Services, } 1982 \\
\text { Singe }\end{array}$ & 89 & 0.53 & 0.07 & 0.40 & 0.71 \\
\hline $\begin{array}{l}\text { Share of Workforce in Services, } 19900 \\
\text { Share of Workfforce in Services, } 1999\end{array}$ & $\begin{array}{l}89 \\
89\end{array}$ & $\begin{array}{l}0.60 \\
0.68\end{array}$ & $\begin{array}{l}0.07 \\
0.06\end{array}$ & $\begin{array}{l}0.47 \\
0.57\end{array}$ & $\begin{array}{l}0.76 \\
0.85\end{array}$ \\
\hline $\begin{array}{l}\text { Share of Worktorce in Services, } 19999 \\
\text { Share of Workforce in Services, } 2010\end{array}$ & ${ }_{89}^{89}$ & 0.53 & 0.09 & 0.37 & $\begin{array}{l}0.85 \\
0.86\end{array}$ \\
\hline Share of Executives in Workforce (age 25-54), 1968 & 89 & 0.041 & 0.013 & 0.02 & 0.114 \\
\hline Share of Executives in Workforce (age 25-54), 1975 & 89 & 0.066 & 0.02 & 0.034 & 0.143 \\
\hline Share of Executives in Workforce (age 25-54), 1982 & & & 0.022 & 0.043 & 0.17 \\
\hline Share of Executives in Workforce (age 25-54), 1990 & 89 & 0.093 & 0.028 & 0.059 & 0.229 \\
\hline Share of Executives in Workforce (age 25-54), 1999 & 89 & 0.095 & 0.029 & 0.062 & 0.249 \\
\hline Share of Executives in Workforce (age 25-54), 2010 & 89 & 0.114 & 0.04 & 0.07 & 0.319 \\
\hline Share of Intermediary Professionals in Workforce (age 25-54), 1968 & 89 & 0.153 & 0.032 & 0.083 & 0.299 \\
\hline Share of Intermediary Professionals in Workforce (age 25-54), 1975 & 89 & 0.218 & 0.034 & 0.147 & 0.315 \\
\hline Share of Intermediary Professionals in Workforce (age 25-54), 1982 & 89 & 0.237 & 0.026 & 0.18 & 0.312 \\
\hline $\begin{array}{l}\text { Share of Intermediary Professionals in Workforce (age 25-54), } 1990 \\
\text { Sal }\end{array}$ & 89 & 0.263 & 0.022 & 0.224 & 0.321 \\
\hline $\begin{array}{l}\text { Share of Intermediary Professionals in Workforce (age 25-54), } 1999 \\
\text { Share of Intermediary Professionals in Workforce age 25-54). } 2010\end{array}$ & $\begin{array}{l}89 \\
89\end{array}$ & 0.297 & $\begin{array}{l}0.021 \\
0.022\end{array}$ & 0.257 & 0.36 \\
\hline $\begin{array}{l}\text { Share of Intermediary Professionals in Workforce (age 25-54), } 2010 \\
\text { Share of Employees in Workforce (age 25-54), 1968 }\end{array}$ & $\begin{array}{l}89 \\
89\end{array}$ & $\begin{array}{l}0.283 \\
0.041\end{array}$ & $\begin{array}{l}0.022 \\
0.013\end{array}$ & 0.244 & $\begin{array}{l}0.369 \\
0.114\end{array}$ \\
\hline $\begin{array}{l}\text { Share of Employees in Workforce (agge 25-54), } 1968 \\
\text { Share of Employees in Workforce (age 25-54), } 1975\end{array}$ & 89 & 0.066 & 0.02 & 0.034 & $\begin{array}{l}0.114 \\
0.143\end{array}$ \\
\hline Share of Employees in Workforce (age 25-54), 1982 & 89 & 0.073 & 0.022 & 0.043 & 0.17 \\
\hline Share of Emplovees in Workforce (age 25-54), 1990 & 89 & 0.093 & 0.028 & 0.059 & 0.229 \\
\hline Share of Employees in Workforce (age 25-54), 1999 & 89 & 0.095 & 0.029 & 0.062 & 0.249 \\
\hline Share of Employees in Workforce (age 25-54), 2010 & 89 & 0.114 & 0.04 & 0.07 & 0.319 \\
\hline \multicolumn{6}{|l|}{ Education Measures, Pre-WWI } \\
\hline Average Share of Literate Individuals Among Conscripts, 1874-1883 & 87 & 0.82 & 0.10 & 0.53 & 0.97 \\
\hline Average Share of Literate Individuals Among Conscripts, 1894-1903 & 87 & 0.94 & 0.04 & 0.82 & 0.99 \\
\hline Average Share of Literate Individuals Among Conscripts, 1910-1912 & 87 & 0.96 & 0.03 & 0.84 & 0.99 \\
\hline \multicolumn{6}{|l|}{$\begin{array}{l}\text { Education Measures, Post-WWII } \\
\text { Post-Secondary Degree (Male 25+). } 1968\end{array}$} \\
\hline $\begin{array}{l}\text { Post-Secondary Degree (Male 25+), } 1968 \\
\text { Post-Secondary Degree (Male 25+) } 1975\end{array}$ & 89 & 0.05 & 0.02 & 0.03 & 0.13 \\
\hline $\begin{array}{l}\text { Post-Secondary Degree (Male 25+), } 19975 \\
\text { Post-Secondary Degree (Male 25+), } 1982\end{array}$ & ${ }_{89}^{89}$ & $\begin{array}{l}0.114 \\
0.14\end{array}$ & 0.03 & 0.069 & 0.212 \\
\hline 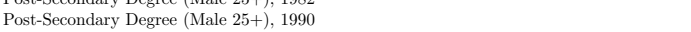 & 89 & 0.19 & 0.04 & 0.13 & 0.36 \\
\hline Post-Secondary Degree (Male 25+), 1999 & 89 & 0.28 & 0.05 & 0.20 & 0.49 \\
\hline Post-Secondary Degree (Male 25+), 2010 & 89 & 0.41 & 0.06 & 0.31 & 0.62 \\
\hline Post-Secondary Degree (Female 25+), 1968 & 89 & 0.01 & 0.01 & 0.01 & 0.05 \\
\hline Post-Secondary Degree (Female 25+), 1975 & 89 & 0.04 & 0.01 & 0.02 & 0.11 \\
\hline Post-Secondary Degree (Female 25+), 1982 & 89 & 0.07 & 0.02 & 0.04 & 0.14 \\
\hline Post-Secondary Degree (Female 25+), 1990 & 89 & 0.09 & 0.03 & 0.05 & 0.21 \\
\hline Post-Secondary Degree (Female 25+), 1999 & 89 & 0.16 & 0.04 & 0.10 & 0.34 \\
\hline Post-Secondary Degree (Female 25+), 2010 & 89 & 0.24 & 0.05 & 0.17 & 0.45 \\
\hline School Enrollment of Men Age 15-17 in 2010 & 89 & 95.55 & 1.03 & 93.10 & 97.70 \\
\hline 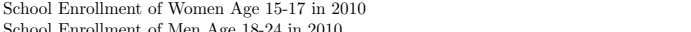 & 89 & 96.68 & 0.88 & 94.40 & 98.10 \\
\hline $\begin{array}{l}\text { School Enrollment of Men Age } 18-24 \text { in } 2010 \\
\text { School Enrollment of Women Age } 18-24 \text { in } 2010\end{array}$ & 89 & $\begin{array}{l}44.25 \\
48.02\end{array}$ & $\begin{array}{l}7.11 \\
8.35\end{array}$ & $\begin{array}{l}30.80 \\
3590\end{array}$ & 61.500 \\
\hline \multicolumn{6}{|l|}{$\begin{array}{l}\text { School Enrollment of Women Age 18-24 in } 2010 \\
\text { Individuals who Express No Interest in Science, } 2001\end{array}$} \\
\hline No Interest in Science & 1511 & 0.087 & 0.28 & 0 & 1 \\
\hline No Use of Science in Work & 1449 & 0.55 & 0.50 & 0 & 1 \\
\hline $\begin{array}{l}\text { Department (Public) Spending on Education, per Inhabitant } \\
\text { Department Spending on Primary Scholing } 1874-1882 \text { ( (in French francs) per Inhabitant }\end{array}$ & & & & & \\
\hline $\begin{array}{l}\text { Department Spending on Primary Schooling } 1874-1882 \text { ( in French francs), , er Inhabitant } \\
\text { Department Spending on Secondary Schooling 2001 (in euros), per Inhabitant }\end{array}$ & $\begin{array}{l}86 \\
88\end{array}$ & 0.23 & 0.11 & 0.05 & 0.67 \\
\hline $\begin{array}{l}\text { Department Spending on Secondary Schooling } 2001 \text { (in euros), per Inhabitant } \\
\text { Explanatory Variables }\end{array}$ & 88 & & 22.39 & 2.61 & 111.04 \\
\hline Horse Power of Steam Engines & 89 & 1839.35 & 3855.33 & 0 & 27638 \\
\hline Average Rainfall & 89 & 878.03 & 156.42 & 642.90 & 1289.24 \\
\hline Average Temperature & 89 & 10.45 & 1.69 & 4.42 & 13.73 \\
\hline $\begin{array}{l}\text { Latitude } \\
\text { Lnd Suitability }\end{array}$ & 89 & 0.74 & 0.19 & 0.21 & 0.98 \\
\hline $\begin{array}{l}\text { Land Suitability } \\
\text { Maritime Department }\end{array}$ & 89 & 46.49 & 2.15 & 41.86 & 50.49 \\
\hline $\begin{array}{l}\text { Marttime Department } \\
\text { Share of Carboniferous Area in Department }\end{array}$ & ${ }_{89}^{89}$ & 0.27 & 0.457 & $0_{0}^{0}$ & $\begin{array}{l}1 \\
0.709\end{array}$ \\
\hline $\begin{array}{l}\text { Share of Carbontiferous Area in Department } \\
\text { Rivers and Tributaries }\end{array}$ & 89 & $\begin{array}{l}0.100 \\
0.562\end{array}$ & 0.499 & 0 & 0.709 \\
\hline & 89 & & & 0 & 1 \\
\hline & 89 & 365.88 & 188.95 & 1 & 918.86 \\
\hline Paris and $\mathrm{s}$ & 89 & 0.03 & 0.18 & 0 & 1 \\
\hline & 89 & 0.03 & & & \\
\hline ation in 1700 (thol & 89 & 20.79 & 57.78 & 0 & 510 \\
\hline & 80 & & & 1089 & \\
\hline $\begin{array}{l}\text { Distance to Fresnes sur Escaut } \\
\text { Temperature Deviations (1856-1859) }\end{array}$ & 89 & 0.19 & 0.11 & 0.01 & $\begin{array}{ll}0.43 \\
0.42\end{array}$ \\
\hline
\end{tabular}


Table A.2: Descriptive statistics: second-generation migrants

\begin{tabular}{lccccc}
\hline \hline & Obs & Mean & Std. Dev. & Min & Max \\
Maternal Origin & & & & & \\
Vocational Certificate (Pre-High School) & 2149 & 0.29 & 0.45 & 0 & 1 \\
Father Worker & 2149 & 0.37 & 0.48 & 0 & \\
1 Mother Worker & 2149 & 0.07 & 0.25 & 0 & 1 \\
Age & 2149 & 46.62 & 7.32 & 35 & 60 \\
Female & 2149 & 0.51 & 0.50 & 0 & 1 \\
Paternal Origin & & & & & \\
Vocational Certificate (Pre-High School) & 2149 & 0.29 & 0.45 & 0 & 1 \\
Father Worker & 2149 & 0.37 & 0.48 & 0 & 1 \\
Mother Worker & 2149 & 0.07 & 0.25 & 0 & 1 \\
Age & 2149 & 46.62 & 7.32 & 35 & 60 \\
Female & 2149 & 0.51 & 0.50 & 0 & 1 \\
Common Origin & & & & & \\
Vocational Certificate (Pre-High School) & 970 & .3185567 & .466157 & 0 & 1 \\
Father Worker & 970 & 0.40 & 0.49 & 0 & 1 \\
Mother Worker & 970 & 0.06 & 0.25 & 0 & 1 \\
Age & 970 & 46.29 & 7.10 & 35 & 60 \\
Female & 970 & 0.54 & 0.50 & 0 & 1 \\
\hline
\end{tabular}

Table A.3: Descriptive statistics: work sector, individuals age 35-64

\begin{tabular}{lccccc}
\hline \hline & Obs & Mean & Std. Dev. & Min & Max \\
Accomodation \& Catering & 1111160 & 0.035 & 0.183 & 0 & 1 \\
Arts \& Entertainment & 1111160 & 0.011 & 0.105 & 0 & 1 \\
Coal Industries & 1111160 & 0.0006 & 0.025 & 0 & 1 \\
Electrical Appliances & 1111160 & 0.009 & 0.095 & 1 & \\
Machinery Repair & 1111160 & 0.016 & 0.124 & 0 & 1 \\
Metallurgy Industries & 1111160 & 0.024 & 0.152 & 0 & 1 \\
Real Estate & 1111160 & 0.013 & 0.113 & 0 & 1 \\
Scientific R\&D & 1111160 & 0.007 & 0.085 & 0 & 1 \\
Wood Industries & 1111160 & 0.013 & 0.114 & 0 & 1 \\
\hline
\end{tabular}


Table A.4: Descriptive statistics: variables for robustness analysis.

\begin{tabular}{|c|c|c|c|c|c|}
\hline & Obs & Mean & Std. Dev. & Min & Max \\
\hline \multicolumn{6}{|l|}{ Steam Engines, $1839-1847 \& 1897$} \\
\hline Number of Steam Engines 1839-1847 & 85 & 29.2 & 66.14303 & 0 & 565 \\
\hline Number of Steam Engines 1897 & 86 & 796.7558 & 939.8229 & 15 & 5805 \\
\hline Horse Power of Steam Engines 1897 & 86 & 15331.73 & 27717.8 & 195 & 186564 \\
\hline \multicolumn{6}{|l|}{ Number of Employees per Firm, 1861-1865 } \\
\hline Number of Employees per Firm, 1861-1865 & 89 & 14.93 & 12.04 & 1.43 & 58.54 \\
\hline \multicolumn{6}{|l|}{ Distance from French cities - aerial distance } \\
\hline Distance from Marseille & 89 & 472.93 & 215.91 & 1 & 902.67 \\
\hline Distance from Lyon & 89 & 330.99 & 152.35 & 1 & 723.27 \\
\hline Distance from Rouen & 89 & 420.42 & 210.31 & 1 & 1025.71 \\
\hline Distance from Mulhouse & 89 & 453.74 & 187.57 & 36.61 & 853.41 \\
\hline Distance from Bordeaux & 89 & 408.59 & 176.16 & 1 & 820.3 \\
\hline Distance from French cities - weeks of travel & & & & & \\
\hline Distance from Fresnes (weeks of travel) & 89 & 0.480 & 0.187 & 0.045 & 0.895 \\
\hline Distance from Paris (weeks of travel) & 89 & 0.404 & 0.180 & 0.003 & 0.925 \\
\hline Distance from Marseille (weeks of travel) & 89 & 0.422 & 0.226 & 0.029 & 0.960 \\
\hline Distance from Lyon (weeks of travel) & 89 & 0.497 & 0.233 & 0.041 & 0.999 \\
\hline Distance from Mulhouse (weeks of travel) & 89 & 0.626 & 0.295 & 0.012 & 1.126 \\
\hline Distance from Rouen (weeks of travel) & 89 & 0.2 & 0.218 & 0.022 & 1.037 \\
\hline Distance from Bordeaux (weeks of travel) & 89 & 0.532 & 0.273 & 0.002 & 1.125 \\
\hline Distance to London & & & & & \\
\hline Distance to London $(\mathrm{km})$ & 89 & 636.23 & 229.93 & 242.93 & 1261.78 \\
\hline Distance to Berlin & & & & & \\
\hline Distance to Berlin $(\mathrm{km})$ & 89 & 1049.53 & 211.45 & 593.85 & 1448.41 \\
\hline Education before 1840 & & & & & \\
\hline Grooms who Signed their Marriage License, $1686-1690$ & 76 & 25.90 & 14.87 & 6.27 & 64.25 \\
\hline Grooms who Signed their Marriage License, $1786-1790$ & 79 & 42.35 & 23.94 & 5.24 & 92.18 \\
\hline Percentage of conscripts who could read, 1827-1829 & 89 & 15.11 & 14.90 & 0.90 & 61.70 \\
\hline Percentage of conscripts who could read, 1831-1835 & 89 & 18.68 & 16.01 & 1.60 & 71.30 \\
\hline University in 1700 & 89 & 0.24 & 0.43 & 0 & 1 \\
\hline University in 1793 & 89 & 0.24 & 0.43 & 0 & 1 \\
\hline Town population in $\mathbf{1 7 8 0}$ & & & & & \\
\hline Town population 1780 & 89 & 31.13 & 68.95 & 0 & 604 \\
\hline The early use of raw material & & & & & \\
\hline Area covered by mines in department & 89 & 0.008 & 0.015 & 0.00009 & 0.086 \\
\hline Iron forges in 1789 & 89 & 2.15 & 8.76 & 0 & 52.00 \\
\hline Iron forges in 1811 & 89 & 2.53 & 11.09 & 0 & 79.00 \\
\hline Presence of iron forges in 1789 & 89 & 0.10 & 0.30 & 0 & 1 \\
\hline Presence of iron forges in 1811 & 89 & 0.10 & 0.30 & 0 & 1 \\
\hline Economic integration & & & & & \\
\hline Market integration during the French Revolution & 86 & 132.71 & 106.95 & 21.00 & 732.00 \\
\hline Railroad connection to Paris in 1860 & 89 & 0.73 & 0.45 & 0 & 1 \\
\hline Population density & & & & & \\
\hline Population density 1801 & 85 & 0.74 & 1.55 & 0.19 & 13.17 \\
\hline Population density 1831 & 86 & 0.91 & 2.18 & 0.22 & 19.50 \\
\hline Population density 1861 & 89 & 1.20 & 4.32 & 0.21 & 40.74 \\
\hline Religious minorities & & & & & \\
\hline Jews in population, 1861 & 89 & 0.002 & 0.005 & 0 & 0.04 \\
\hline Protestants in population, 1861 & 89 & 0.021 & 0.053 & 0.00003 & 0.31 \\
\hline Share of the native population & & & & & \\
\hline Share of the native population in each department, 1901 & 87 & 0.85 & 0.09 & 0.47 & 0.98 \\
\hline Share of the native population in each department, 2010 & 89 & 0.57 & 0.11 & 0.25 & 0.78 \\
\hline World War I and World War II & & & & & \\
\hline Destroyed Buildings WWI & 86 & 10802.81 & 38701.6 & 0 & 280175 \\
\hline Destroyed Buildings WWII & 86 & 13530.36 & 24260.73 & 0 & 122285 \\
\hline Share of unionized workers in workforce & & & & & \\
\hline Share of unionized workers in workforce, 1930 & 89 & 0.17 & 0.07 & 0.02 & 0.37 \\
\hline Average adult wage, 1901 (in French Francs) & & & & & \\
\hline Average male wage, 1901 & 85 & 3.15 & 0.63 & 2.15 & 6.02 \\
\hline Industrial concentration and firm size & & & & & \\
\hline Concentration index - Horse Power by Sector & 85 & 0.40 & 0.20 & 0.12 & 1 \\
\hline Concentration Index - Share of Employees in Industry & 89 & 0.314 & 0.162 & 0.110 & 0.822 \\
\hline Number of Employees per Firm 1861-1865 & 89 & 14.93 & 12.04 & 1.43 & 58.54 \\
\hline Weighted tariffs across sectors & & & & & \\
\hline Weighted tariffs across sectors 1865 & 86 & 4.18 & 1.40 & 0.29 & 8.79 \\
\hline Weighted tariffs across sectors 1901 & 86 & 8.40 & 2.57 & 3.30 & 15.29 \\
\hline Weighted tariffs across sectors 1919 & 86 & 4.17 & 0.88 & 2.36 & 5.95 \\
\hline Weighted tariffs across sectors 1953 & 86 & 12.57 & 2.82 & 6.43 & 17.10 \\
\hline Weighted tariffs across sectors 1970 & 86 & 12.62 & 3.19 & 6.00 & 25.00 \\
\hline Weighted tariffs across sectors 1990 & 86 & 8.68 & 2.55 & 4.72 & 13.83 \\
\hline Weighted tariffs across sectors 2000 & 86 & 10.08 & 7.40 & 2.14 & 39.78 \\
\hline Environmental regulation & & & & & \\
\hline CO2 Emission 2005 & 89 & 1426615 & 3553433 & 0 & 21265675 \\
\hline Ratio CO2 Quota 2012 over Emission 2005 & 89 & 0.94 & 0.36 & 0 & 1.89 \\
\hline Weather shocks & & & & & \\
\hline Squared Temperature Deviations (Spring 1856-1859) (Baseline Spring 1831-1855) & 89 & 0.14 & 0.09 & 0.03 & 0.34 \\
\hline Squared Temperature Deviations (Summer 1856-1859) (Baseline Summer 1831-1855) & 89 & 0.89 & 0.31 & 0.07 & 1.32 \\
\hline Squared Temperature Deviations (Summer 1856-1859) (Baseline Summer 1831-1855) & 87 & 0.08 & 0.14 & 0.00 & 0.67 \\
\hline Squared Temperature Deviations (1844-1847) (Baseline Fall 1819-1843) & 89 & 0.01 & 0.014 & $1.48 \mathrm{e}-07$ & 0.073 \\
\hline Squared Temperature Deviations (1848-1851) (Baseline Fall 1823-1847) & 89 & 0.61 & 0.13 & 0.41 & 1.045829 \\
\hline Squared Temperature Deviations (1852-1855) (Baseline Fall 1827-1851) & 89 & 0.08 & 0.05 & 0.01 & 0.2034184 \\
\hline Squared Temperature Deviations (1866-1869) (Baseline Fall 1841-1865) & 89 & 0.01 & 0.01 & $9.26 \mathrm{e}-07$ & .069093 \\
\hline Squared Rainfall Deviations (1856-1859) (Baseline Fall 1831-1855) & 89 & 0.02 & 0.03 & $1.03 \mathrm{e}-06$ & 0.12 \\
\hline Squared Deviation Average Rainfall in Fall 1856-1859 (Baseline Fall 1831-1855) & 89 & 1123.94 & 821.55 & 5.23 & 3113.8 \\
\hline Wheat prices & & & & & \\
\hline Wheat Prices Fall 1856-1859 & 86 & 0.04 & 0.04 & -0.07 & 0.14 \\
\hline
\end{tabular}


Table A.5: Descriptive statistics: tariffs across sectors.

\begin{tabular}{lccccc}
\hline \hline & 1865 & 1901 & 1919 & 1990 & 2000 \\
& & & & & \\
Ceramics & 25.08 & 7.99 & 6.89 & 6.91 & 4.59 \\
Chemistry & 2.57 & 2.34 & 1.92 & 7.91 & 3.49 \\
Clothing & 8.82 & 10.25 & 5.31 & 21.11 & 12.24 \\
Construction & 5.44 & 4.61 & 5.42 & 4.18 & 1.70 \\
Food & 6.19 & 15.29 & 5.35 & 11.43 & 39.78 \\
Furniture & 12.68 & 12.68 & 8.91 & 6.48 & 3.27 \\
Leather & 10.37 & 10.37 & 2.32 & 2.31 & 1.85 \\
Lighting & 2.57 & 2.34 & 1.92 & 5.51 & 1.95 \\
Luxury Goods & 5.44 & 4.61 & 5.15 & 0.00 & 0.00 \\
Metal Objects & 1.28 & 2.72 & 5.88 & 6.04 & 2.89 \\
Metallurgy & 1.28 & 2.72 & 5.88 & 4.99 & 1.99 \\
Mines & 4.86 & 12.87 & 3.01 & 4.46 & 3.20 \\
Sciences \& Arts & 5.44 & 4.61 & 5.15 & 5.45 & 5.18 \\
Textile & 4.48 & 9.56 & 2.39 & 14.66 & 6.99 \\
Transportation & 5.44 & 4.61 & 5.15 & 8.32 & 5.86 \\
Wood & 0.16 & 9.80 & 2.39 & 4.53 & 2.76 \\
\hline
\end{tabular}


Table A.6: Descriptive statistics: horse power of steam engines and workers per industrial sector.

\begin{tabular}{|c|c|c|c|c|c|}
\hline & Obs & Mean & Std. Dev. & Min & $\operatorname{Max}$ \\
\hline \multicolumn{6}{|c|}{ Horse Power of Steam Engines per Industrial Sector } \\
\hline Ceramics & 89 & 13.56 & 44.92 & 0 & 304 \\
\hline Chemistry & 89 & 54.11 & 222.78 & 0 & 2008 \\
\hline Clothing & 89 & 6.34 & 24.46 & 0 & 215 \\
\hline Construction & 89 & 20.69 & 40.22 & 0 & 223 \\
\hline Food & 89 & 274.16 & 769.05 & 0 & 5744 \\
\hline Furniture & 89 & 14.24 & 66.09 & 0 & 448 \\
\hline Leather & 89 & 11.85 & 31.60 & 0 & 266 \\
\hline Lighting & 89 & 10.16 & 66.84 & 0 & 629 \\
\hline Luxury Goods & 89 & 6.31 & 44.12 & 0 & 411 \\
\hline Metal Objects & 89 & 102.19 & 279.32 & 0 & 2063 \\
\hline Metallurgy & 89 & 377.10 & 901.76 & 0 & 5085 \\
\hline Mines & 89 & 314.98 & 1229.07 & 0 & 10325 \\
\hline Sciences \& Arts & 89 & 56.42 & 130.69 & 0 & 988 \\
\hline Textile & 89 & 540.62 & 1679.96 & 0 & 12057 \\
\hline Transportation & 89 & 9.51 & 43.12 & 0 & 382 \\
\hline Wood & 89 & 27.25 & 67.56 & 0 & 565 \\
\hline Horse Power of Steam Engines 1860-1865 & 89 & 1839.35 & 3855.33 & 0 & 27638 \\
\hline \multicolumn{6}{|c|}{ Number of Workers per Industrial Sector } \\
\hline Ceramics & 89 & 582.35 & 1066.79 & 0 & 5763 \\
\hline Chemistry & 89 & 282.09 & 746.59 & 0 & 5933 \\
\hline Clothing & 89 & 1091.40 & 4303.00 & 0 & 38777 \\
\hline Construction & 89 & 756.43 & 702.96 & 0 & 4232 \\
\hline Food & 89 & 2025.03 & 3623.52 & 42 & 30079 \\
\hline Furniture & 89 & 191.40 & 1632.74 & 0 & 15415 \\
\hline Leather & 89 & 276.29 & 863.57 & 0 & 8040 \\
\hline Lighting & 89 & 80.66 & 377.58 & 0 & 3552 \\
\hline Luxury Goods & 89 & 230.98 & 1584.69 & 0 & 14855 \\
\hline Metal Objects & 89 & 1172.34 & 2770.68 & 0 & 21263 \\
\hline Metallurgy & 89 & 1246.40 & 1841.94 & 0 & 8394 \\
\hline Mines & 89 & 1253.65 & 2433.45 & 0 & 15442 \\
\hline Sciences \& Arts & 89 & 847.64 & 2601.94 & 0 & 20502 \\
\hline Textile & 89 & 8004.17 & 13922.15 & 0 & 76726 \\
\hline Transportation & 89 & 373.45 & 1754.09 & 0 & 15623 \\
\hline Wood & 89 & 188.81 & 395.50 & 0 & 3132 \\
\hline Number of Workers & 89 & 18603.10 & 28178.16 & 1027 & 198488 \\
\hline
\end{tabular}




\section{Appendix B. Additional Robustness Analysis}

Table B.1: The determinants of the diffusion of the steam engine: distances from Fresnes-sur-Escaut and other major French cities by foot measured in travel weeks

\begin{tabular}{|c|c|c|c|c|c|c|c|}
\hline & $\begin{array}{l}\text { (1) } \\
\text { OLS }\end{array}$ & $\begin{array}{l}\text { (2) } \\
\text { OLS }\end{array}$ & $\begin{array}{c}\text { (3) } \\
\text { OLS } \\
\text { Log Horse }\end{array}$ & $\begin{array}{c}\text { OLS } \\
\text { OLS } \\
\text { Oower of Ste }\end{array}$ & $\begin{array}{c}(5) \\
\text { OLS } \\
\text { am Engines }\end{array}$ & $\begin{array}{c}\text { (6) } \\
\text { OLS }\end{array}$ & $\begin{array}{l}\text { (7) } \\
\text { OLS }\end{array}$ \\
\hline Distance from Fresnes (weeks of travel) & $-5.910^{* * *}$ & $-7.771^{* * *}$ & $-5.715^{* * *}$ & $-6.144^{* * *}$ & $-6.069^{* * *}$ & $-5.857^{* * *}$ & $-5.627 * * *$ \\
\hline Distance from Paris (weeks of travel) & & $\begin{array}{c}2.366 \\
{[1.598]}\end{array}$ & & & & & \\
\hline Distance from Marseille (weeks of travel) & & & $\begin{array}{c}0.879 \\
{[0.765]}\end{array}$ & & & & \\
\hline Distance from Lyon (weeks of travel) & & & & $\begin{array}{c}0.644 \\
{[0.772]}\end{array}$ & & & \\
\hline Distance from Rouen (weeks of travel) & & & & & $\begin{array}{c}0.271 \\
{[0.886]}\end{array}$ & & \\
\hline Distance from Mulhouse (weeks of travel) & & & & & & $\begin{array}{c}-0.0941 \\
{[0.663]}\end{array}$ & \\
\hline Distance from Bordeaux (weeks of travel) & & & & & & & $\begin{array}{c}0.540 \\
{[0.748]}\end{array}$ \\
\hline Adjusted $R^{2}$ & 0.295 & 0.302 & 0.297 & 0.292 & 0.288 & 0.287 & 0.292 \\
\hline Observations & 89 & 89 & 89 & 89 & 89 & 89 & 89 \\
\hline
\end{tabular}

Note: The dependent variable is in logarithm. Robust standard errors are reported in brackets. *** indicates significance at the $1 \%$-level, $* *$ at the $5 \%$-level, $*$ at the $10 \%$-level. 
Table B.2: Industrialization and income per capita: using the residuals from regressing the instruments on one another as the instrument

\begin{tabular}{|c|c|c|c|c|c|}
\hline & $\begin{array}{c}\text { OLS } \\
\text { OLStance to Fresnes } \\
\end{array}$ & $\begin{array}{c}(2) \\
\text { IV } \\
\text { Log GDP per capita } 1860 \\
\end{array}$ & $\begin{array}{c}\text { (3) } \\
\text { IV } \\
\text { Log GDP per capita } 1901 \\
\end{array}$ & $\begin{array}{c}(4) \\
\text { IV } \\
\text { Log GDP per capita } 1930 \\
\end{array}$ & $\begin{array}{c}\text { (5) } \\
\text { IV } \\
\text { Log GDP per capita 2001-2005 }\end{array}$ \\
\hline Temperature Deviations & $\begin{array}{l}-36.79 \\
{[231.4]}\end{array}$ & & & & \\
\hline Log Horse Power of Steam Engines & & $\begin{array}{l}0.132 * * * \\
{[0.0437]}\end{array}$ & $\begin{array}{c}0.266^{* * *} \\
{[0.0793]}\end{array}$ & $\begin{array}{c}0.127^{* * *} \\
{[0.0297]}\end{array}$ & $\begin{array}{c}-0.076^{* * *} \\
{[0.0243]}\end{array}$ \\
\hline Geographic characteristics & No & Yes & Yes & Yes & Yes \\
\hline Institutional characteristics & No & Yes & Yes & Yes & Yes \\
\hline Pre-industrial development & No & Yes & Yes & Yes & Yes \\
\hline Adjusted R2 & -0.011 & & & & \\
\hline Observations & 89 & 87 & 85 & 87 & 89 \\
\hline Residuals & & $\begin{array}{c}-0.0103^{* * *} \\
{[0.002]}\end{array}$ & $\begin{array}{c}-0.0098^{* * *} \\
{[0.002]}\end{array}$ & $\begin{array}{c}-0.0102^{* * *} \\
{[0.002]}\end{array}$ & $\begin{array}{c}-0.0106^{* * *} \\
{[0.002]}\end{array}$ \\
\hline F-stat (1st stage) & & 25.170 & 24.147 & 25.749 & 29.449 \\
\hline
\end{tabular}

Note: All regressions include a dummy variable for the three departments which had no steam engine in 1860-1865. Geographic characteristics include the department's latitude, land suitability, average rainfall and temperature, share of carboniferous area, distance to Paris as well as dummies for the presence of rivers and tributaries, maritime and border departments. Institutional measures include dummies for Alsace-Lorraine and for Paris and its suburbs. Pre-industrial development characteristics include a measure of the urban population in 1700 . Robust standard errors are reported in brackets. *** indicates significance at the $1 \%$-level, $* *$ at the $5 \%$-level, * at the $10 \%$-level. 
Table B.3: Weather shocks and the adoption of the steam engine

\begin{tabular}{|c|c|c|c|c|c|}
\hline & $\begin{array}{l}(1) \\
\text { OLS }\end{array}$ & $\begin{array}{c}(2) \\
\text { OLS } \\
\text { Log Horse } \\
\end{array}$ & $\begin{array}{c}\text { OLS } \\
\text { Power of Ste } \\
\end{array}$ & $\begin{array}{c}\text { OLS } \\
\text { OLS } \\
\text { Engines } \\
\end{array}$ & $\begin{array}{c}(5) \\
\text { OLS }\end{array}$ \\
\hline Temperature Deviations (1856-1859) (Baseline Fall 1831-1855) & $\begin{array}{c}-6.950^{* * *} \\
{[1.690]}\end{array}$ & $\begin{array}{c}-5.639^{* * *} \\
{[1.825]}\end{array}$ & $\begin{array}{c}-8.131^{* * *} \\
{[2.175]}\end{array}$ & $\begin{array}{c}-6.986^{* * *} \\
{[2.581]}\end{array}$ & $\begin{array}{c}-6.364^{* * *} \\
{[1.629]}\end{array}$ \\
\hline Temperature Deviations(Spring 1856-1859) (Baseline Spring 1831-1855) & $\begin{array}{c}2.147 \\
{[3.529]}\end{array}$ & & & $\begin{array}{c}3.314 \\
{[3.402]}\end{array}$ & \\
\hline Temperature Deviations (Summer 1856-1859) (Baseline Summer 1831-1855) & & $\begin{array}{l}-1.740 \\
{[1.093]}\end{array}$ & & $\begin{array}{l}-1.528 \\
{[1.176]}\end{array}$ & \\
\hline Temperature Deviations (Winter 1856-1859) (Baseline Winter 1831-1855) & & & $\begin{array}{l}-1.774 \\
{[1.220]}\end{array}$ & $\begin{array}{l}-1.182 \\
{[1.316]}\end{array}$ & \\
\hline Rainfall Deviations (1856-1859) (Baseline Fall 1831-1855) & & & & & $\begin{array}{c}0.0003 \\
{[0.0002]} \\
\end{array}$ \\
\hline Geographic characteristics & Yes & Yes & Yes & Yes & Yes \\
\hline Institutional characteristics & Yes & Yes & Yes & Yes & Yes \\
\hline Pre-industrial development & Yes & Yes & Yes & Yes & Yes \\
\hline Adjusted R2 & 0.635 & 0.643 & 0.637 & 0.636 & 0.639 \\
\hline Observations & 89 & 89 & 87 & 87 & 89 \\
\hline
\end{tabular}

Note: The dependent variable is in logarithm. All regressions include a dummy variable for the three departments which had no steam engine in $1860-1865$.

Geographic characteristics include the department's latitude, land suitability, average rainfall and temperature, share of carboniferous area, distance to Paris as well as dummies for the presence of rivers and tributaries, maritime and border departments. Institutional measures include dummies for Alsace-Lorraine and for Paris and its suburbs. Pre-industrial development characteristics include a measure of the urban population in 1700. Robust standard errors are reported in brackets. $* * *$ indicates significance at the $1 \%$-level, $* *$ at the $5 \%$-level, $*$ at the $10 \%$-level. 
Table B.4: Weather shocks and adoption of the steam engine: Robustness Checks

\begin{tabular}{|c|c|c|c|c|c|}
\hline & $\begin{array}{c}1) \\
\text { OLS }\end{array}$ & $\begin{array}{c}(2) \\
\text { OLS } \\
\text { Log Horse }\end{array}$ & $\begin{array}{c}\text { OLS } \\
\text { Ower of Ste }\end{array}$ & $\begin{array}{c}\text { (4) } \\
\text { OLS } \\
\text { Engines }\end{array}$ & $\begin{array}{c}(5) \\
\text { OLS }\end{array}$ \\
\hline Temperature Deviations (1856-1859) (Baseline Fall 1831-1855) & $\begin{array}{c}-7.054^{* * *} \\
{[1.695]}\end{array}$ & $\begin{array}{c}-6.897^{* * *} \\
{[1.620]}\end{array}$ & $\begin{array}{c}-6.634^{* * *} \\
{[1.647]}\end{array}$ & $\begin{array}{c}-7.332^{* * *} \\
{[1.716]}\end{array}$ & $\begin{array}{c}-6.484^{* *} \\
{[2.497]}\end{array}$ \\
\hline Temperature Deviations (1844-1847) (Baseline Fall 1819-1843) & $\begin{array}{c}7.899 \\
{[9.428]}\end{array}$ & & & & \\
\hline Temperature Deviations (1848-1851) (Baseline Fall 1823-1847) & & $\begin{array}{l}2.588 \\
{[1.614]}\end{array}$ & & & \\
\hline Temperature Deviations (1852-1855) (Baseline Fall 1827-1851) & & & $\begin{array}{l}-3.642 \\
{[12.99]}\end{array}$ & & \\
\hline Temperature Deviations (1866-1869) (Baseline Fall 1841-1865) & & & & $\begin{array}{c}11.37 \\
{[11.55]}\end{array}$ & \\
\hline Temperature Deviations (1870-1873) (Baseline Fall 1845-1869) & & & & & $\begin{array}{l}-1.571 \\
{[10.49]}\end{array}$ \\
\hline Geographic characteristics & Yes & Yes & Yes & Yes & Yes \\
\hline Institutional characteristics & Yes & Yes & Yes & Yes & Yes \\
\hline Pre-industrial development & Yes & Yes & Yes & Yes & Yes \\
\hline Adjusted R2 & 0.635 & 0.643 & 0.634 & 0.637 & 0.633 \\
\hline Observations & 89 & 89 & 89 & 89 & 89 \\
\hline
\end{tabular}

Note: The dependent variable is in logarithm. All regressions include a dummy variable for the three departments which had no steam engine in $1860-1865$. Geographic characteristics include the department's latitude, land suitability, average rainfall and temperature, share of carboniferous area, distance to Paris as well as dummies for the presence of rivers and tributaries, maritime and border departments. Institutional measures include dummies for Alsace-Lorraine and for Paris and its suburbs. Pre-industrial development characteristics include a measure of the urban population in 1700 . Robust standard errors are reported in brackets. $* * *$ indicates significance at the $1 \%$-level, $* *$ at the $5 \%$-level, $*$ at the $10 \%$-level. 
Table B.5: Weather shocks and adoption of the steam engine: Mechanism

\begin{tabular}{|c|c|c|c|c|c|}
\hline & \multicolumn{2}{|c|}{$\begin{array}{c}\text { Log Wheat Prices Fall 1856-1859 } \\
\text { Baseline Fall 1831-1855 }\end{array}$} & \multicolumn{3}{|c|}{$\begin{array}{c}\text { Log Horse Power of } \\
\text { Steam Engines }\end{array}$} \\
\hline Distance to Fresnes & & & $\begin{array}{c}-0.0075^{* * *} \\
{[0.0026]}\end{array}$ & $\begin{array}{c}-0.0116^{* * *} \\
{[0.0025]}\end{array}$ & $\begin{array}{c}-0.0082^{* * *} \\
{[0.0026]}\end{array}$ \\
\hline Temperature Deviations (1856-1859) & $\begin{array}{c}0.0998^{* *} \\
{[0.0408]}\end{array}$ & $\begin{array}{l}0.112^{* *} \\
{[0.0485]}\end{array}$ & $\begin{array}{c}-4.254^{* *} \\
{[2.092]}\end{array}$ & & $\begin{array}{l}-3.233 \\
{[2.002]}\end{array}$ \\
\hline Wheat Prices (Fall 1856-1859) & & & & $\begin{array}{c}-10.79^{* *} \\
{[4.636]}\end{array}$ & $\begin{array}{c}-9.306^{*} \\
{[4.818]}\end{array}$ \\
\hline Geographic characteristics & No & Yes & Yes & Yes & Yes \\
\hline Institutional characteristics & No & Yes & Yes & Yes & Yes \\
\hline Pre-industrial development & No & Yes & Yes & Yes & Yes \\
\hline Adjusted R2 & 0.048 & 0.418 & 0.646 & 0.654 & 0.659 \\
\hline Observations & 86 & 86 & 89 & 86 & 86 \\
\hline
\end{tabular}

Note: The dependent variable is in logarithm. All regressions include a dummy variable for the three departments which had no steam engine in $1860-1865$. Geographic characteristics include the department's latitude, land suitability, average rainfall and temperature, share of carboniferous area, distance to Paris as well as dummies for the presence of rivers and tributaries, maritime and border departments. Institutional measures include dummies for Alsace-Lorraine and for Paris and its suburbs. Pre-industrial development characteristics include a measure of the urban population in 1700. Robust standard errors are reported in brackets. $* * *$ indicates significance at the $1 \%$-level, $* *$ at the $5 \%$-level, $*$ at the $10 \%$-level. 
Table B.6: Weather shocks and adoption of the steam engine: yearly wheat prices

\begin{tabular}{|c|c|c|c|c|c|}
\hline & \multicolumn{2}{|c|}{$\begin{array}{c}\text { Log Yearly Wheat Prices 1856-1859 } \\
\text { Baseline 1831-1855 }\end{array}$} & \multicolumn{3}{|c|}{$\begin{array}{l}\text { Log Horse Power of } \\
\text { Steam Engines }\end{array}$} \\
\hline Distance to Fresnes & & & $\begin{array}{c}-0.0075 * * * \\
{[0.0026]} \\
-4.254 * *\end{array}$ & $\begin{array}{c}-0.012^{* * *} \\
{[0.0026]}\end{array}$ & $\begin{array}{c}-0.0081^{* * *} \\
{[0.0028]} \\
-3856 *\end{array}$ \\
\hline Temperature Deviations (Fall 1856-1859) & $\begin{array}{c}0.0222^{* * *} \\
{[0.00752]}\end{array}$ & $\begin{array}{l}0.0247^{* *} \\
{[0.00953]}\end{array}$ & $\begin{array}{c}-4.254^{* *} \\
{[2.092]}\end{array}$ & & $\begin{array}{c}-3.856^{*} \\
{[2.282]}\end{array}$ \\
\hline $\begin{array}{l}\text { Yearly Wheat Price Deviation 1856-1859 } \\
\text { (Baseline 1831-1855) }\end{array}$ & & & & $\begin{array}{l}-29.81 \\
{[26.99]}\end{array}$ & $\begin{array}{l}-17.77 \\
{[28.62]}\end{array}$ \\
\hline Geographic characteristics & No & Yes & Yes & Yes & Yes \\
\hline Institutional characteristics & No & Yes & Yes & Yes & Yes \\
\hline Pre-industrial characteristics & No & Yes & Yes & Yes & Yes \\
\hline Adjusted R2 & 0.07 & 0.36 & 0.65 & 0.63 & 0.64 \\
\hline Observations & 86 & 86 & 89 & 86 & 86 \\
\hline
\end{tabular}

Note: The dependent variable is in logarithm. All regressions include a dummy variable for the three departments which had no steam engine in $1860-1865$. Geographic characteristics include the department's latitude, land suitability, average rainfall and temperature, share of carboniferous area, distance to Paris as well as dummies for the presence of rivers and tributaries, maritime and border departments. Institutional measures include dummies for Alsace-Lorraine and for Paris and its suburbs. Pre-industrial development characteristics include a measure of the urban population in 1700. Robust standard errors are reported in brackets. $* * *$ indicates significance at the $1 \%$-level, $* *$ at the $5 \%$-level, $*$ at the $10 \%$-level. 
Table B.7: Rainfall shocks and the price of wheat: Falsification tests

\begin{tabular}{|c|c|c|c|c|}
\hline & $\begin{array}{c}1) \\
\text { OLS } \\
\text { Log }\end{array}$ & $\begin{array}{c}(2) \\
\text { OLS } \\
\text { heat Pric } \\
\text { aseline Fa }\end{array}$ & $\begin{array}{c}\text { (3) } \\
\text { OLS } \\
\text { s Fall } 185 \\
\text { l } 1831-18\end{array}$ & $\begin{array}{c}\text { (4) } \\
\text { OLS } \\
-1859 \\
5\end{array}$ \\
\hline Temperature Deviations 1856-1859 (Baseline Fall 1831-1855) & $\begin{array}{l}0.113^{* *} \\
{[0.0484]}\end{array}$ & $\begin{array}{l}0.0952^{*} \\
{[0.0525]}\end{array}$ & $\begin{array}{l}0.0984^{*} \\
{[0.0503]}\end{array}$ & $\begin{array}{l}0.101 * * \\
{[0.0474]}\end{array}$ \\
\hline Rainfall Deviations Spring 1856-1859 (Baseline Spring 1831-1855) & $\begin{array}{l}-0.0002 \\
{[0.0020]}\end{array}$ & & & \\
\hline Rainfall Deviations Summer 1856-1859 (Baseline Summer 1831-1855) & & $\begin{array}{c}0.0033 \\
{[0.0021]}\end{array}$ & & \\
\hline Rainfall Deviations Fall 1856-1859 (Baseline Fall 1831-1855) & & & $\begin{array}{l}-0.0041 \\
{[0.0034]}\end{array}$ & \\
\hline Rainfall Deviations Winter 1856-1859 (Baseline Winter 1831-1855) & & & & $\begin{array}{l}-0.0074 \\
{[0.0072]}\end{array}$ \\
\hline Geographic characteristics & Yes & Yes & Yes & Yes \\
\hline Institutional characteristics & Yes & Yes & Yes & Yes \\
\hline Pre-industrial development & Yes & Yes & Yes & Yes \\
\hline Adjusted R2 & 0.410 & 0.429 & 0.418 & 0.417 \\
\hline Observations & 86 & 86 & 86 & 86 \\
\hline
\end{tabular}

Note: The dependent variable is in logarithm. All regressions include a dummy variable for the three departments which had no steam engine in $1860-1865$. Geographic characteristics include the department's latitude, land suitability, average rainfall and temperature, share of carboniferous area, distance to Paris as well as dummies for the presence of rivers and tributaries, maritime and border departments. Institutional measures include dummies for Alsace-Lorraine and for Paris and its suburbs. Pre-industrial development characteristics include a measure of the urban population in 1700. Robust standard errors are reported in brackets. $* *$ indicates significance at the $1 \%$-level, $* *$ at the $5 \%$-level, $*$ at the $10 \%$-level. 
Table B.8: Weather shocks and steam engines in 1897

\begin{tabular}{lcc}
\hline \hline & $(1)$ & $(2)$ \\
& OLS & OLS \\
& Log Horse Power of Steam Engines 1897 \\
\hline Temperature Deviations (1856-1859) & $-3.043^{* *}$ & -0.608 \\
& {$[1.439]$} & {$[1.418]$} \\
Log Horse Power of Steam Engines (1860-1865) & & $0.325^{* * *}$ \\
& & {$[0.0650]$} \\
\hline & & \\
Geographic characteristics & Yes & Yes \\
Institutional characteristics & Yes & Yes \\
Pre-industrial development & Yes & Yes \\
\hline & & \\
Adjusted R2 & 0.602 & 0.727 \\
Observations & 86 & 86 \\
\hline
\end{tabular}

Note: The dependent variable is in logarithm. Geographic characteristics include the department's latitude, land suitability, average rainfall and temperature, share of carboniferous area, distance to Paris as well as dummies for the presence of rivers and tributaries, maritime and border departments. Institutional measures include dummies for Alsace-Lorraine and for Paris and its suburbs. Pre-industrial development characteristics include a measure of the urban population in 1700 . Robust standard errors are reported in brackets. $* * *$ indicates significance at the $1 \%$-level, $* *$ at the $5 \%$-level, $*$ at the $10 \%$-level. 
Table B.9: Industrialization and income per capita 1860, 1901, 1930 \& 2001-2005: Robustness check temperature shock as sole IV

\begin{tabular}{lcccc}
\hline \hline & $(1)$ & $(2)$ & $(3)$ & $(4)$ \\
& IV & IV & IV & IV \\
& 1860 & 1901 & 1930 & $2001-2005$ \\
\hline Log Horse Power of Steam Engines & $0.0811^{* *}$ & $0.211^{* *}$ & $0.0968^{* * *}$ & $-0.0400^{*}$ \\
& {$[0.0410]$} & {$[0.100]$} & {$[0.0313]$} & {$[0.0217]$} \\
\hline Geographic characteristics & Yes & Yes & Yes & Yes \\
Institutional characteristics & Yes & Yes & Yes & Yes \\
Pre-industrial development & Yes & Yes & Yes & Yes \\
\hline \multirow{2}{*}{ Observations } & 87 & 85 & 87 & 89 \\
\hline \multicolumn{2}{c}{ First stage: Instrumented variable - Log Horse Power of Steam Engines } \\
\hline \multirow{2}{*}{ Temperature Deviations } & $-6.739^{* * *}$ & $-6.440^{* * *}$ & $-6.698^{* * *}$ & $-6.691^{* * *}$ \\
& {$[1.852]$} & {$[1.920]$} & {$[1.910]$} & {$[1.738]$} \\
F-stat (1st stage) & 13.245 & 11.249 & 12.302 & 14.825 \\
\hline
\end{tabular}

Note: All regressions include a dummy variable for the three departments which had no steam engine in 1860-1865. Aerial distances are measured in kilometers. Other explanatory variables, except the dummies, and the dependent variables are in logarithm. Geographic characteristics include the department's latitude, land suitability, average rainfall and temperature, share of carboniferous area, distance to Paris as well as dummies for the presence of rivers and tributaries, maritime and border departments. Institutional measures include dummies for Alsace-Lorraine and for Paris and its suburbs. Pre-industrial development characteristics include a measure of the urban population in 1700 . Robust standard errors are reported in brackets. *** indicates significance at the $1 \%$-level, ** at the $5 \%$-level, * at the $10 \%$-level. 
Table B.10: Industrialization and income per capita 1860, 1901, 1930 \& 2001-2005 Robustness check Distance to Fresnes-sur-Escaut as sole IV

\begin{tabular}{|c|c|c|c|c|}
\hline & $(1)$ & $\begin{array}{ll}(2) \\
\text { IV }\end{array}$ & (3) & (4) \\
\hline & \multicolumn{4}{|c|}{ Log GDP per capita } \\
\hline & 1860 & 1901 & 1930 & $2001-2005$ \\
\hline Log Horse Power of Steam Engines & $\begin{array}{c}0.124^{* * *} * \\
{[0.0401]}\end{array}$ & $\begin{array}{c}0.250^{* * *} * \\
{[0.0766]}\end{array}$ & $\begin{array}{c}0.103^{* * *} \\
{[0.0258]}\end{array}$ & $\begin{array}{c}-0.0816^{* * *} \\
{[0.0263]} \\
\end{array}$ \\
\hline Geographic characteristics & Yes & Yes & Yes & Yes \\
\hline Institutional characteristics & Yes & Yes & Yes & Yes \\
\hline Pre-industrial development & Yes & Yes & Yes & Yes \\
\hline Observations & 87 & 85 & 87 & 89 \\
\hline \multicolumn{5}{|c|}{ First stage: Instrumented variable - Log Horse Power of Steam Engines } \\
\hline Distance to Fresnes & $\begin{array}{c}-0.0117^{* * *} \\
{[0.0024]}\end{array}$ & $\begin{array}{c}-0.0113^{* * *} \\
{[0.0024]}\end{array}$ & $\begin{array}{c}-0.0117^{* * *} * \\
{[0.0024]}\end{array}$ & $\begin{array}{c}-0.0121^{* * *} \\
{[0.0024]}\end{array}$ \\
\hline F-stat (1st stage) & 23.866 & 22.512 & 23.608 & 24.635 \\
\hline
\end{tabular}

Note: All regressions include a dummy variable for the three departments which had no steam engine in 1860-1865. Aerial distances are measured in kilometers. Other explanatory variables, except the dummies, and the dependent variables are in logarithm. Geographic characteristics include the department's latitude, land suitability, average rainfall and temperature, share of carboniferous area, distance to Paris as well as dummies for the presence of rivers and tributaries, maritime and border departments. Institutional measures include dummies for Alsace-Lorraine and for Paris and its suburbs. Pre-industrial development characteristics include a measure of the urban population in 1700 . Robust standard errors are reported in brackets. *** indicates significance at the $1 \%-$ level, ** at the $5 \%$-level, $*$ at the $10 \%$-level. 
Table B.11: The determinants of the diffusion of the steam engine: robustness analysis

\begin{tabular}{|c|c|c|c|c|c|c|c|c|c|c|c|c|c|c|c|}
\hline & $\begin{array}{c}(1) \\
\text { OLS }\end{array}$ & $\begin{array}{l}(2) \\
\text { OLS }\end{array}$ & $\begin{array}{c}(3) \\
\text { OLS }\end{array}$ & $\begin{array}{l}(4) \\
\text { OLS }\end{array}$ & $\begin{array}{c}(5) \\
\text { OLS }\end{array}$ & $\begin{array}{c}(6) \\
\text { OLS }\end{array}$ & $\begin{array}{c}\text { (7) } \\
\text { OLS } \\
\text { Log Horse P } \\
\end{array}$ & $\begin{array}{c}\text { (8) } \\
\text { OLS } \\
\text { Power of Stea }\end{array}$ & $\begin{array}{c}\text { OL) } \\
\text { OLS } \\
\text { am Engines } \\
\end{array}$ & $\begin{array}{l}\text { (10) } \\
\text { OLS }\end{array}$ & $\begin{array}{l}\text { (11) } \\
\text { OLS }\end{array}$ & $\begin{array}{l}\text { (12) } \\
\text { OLS }\end{array}$ & $\begin{array}{l}\text { (13) } \\
\text { OLS }\end{array}$ & $\begin{array}{l}\text { (14) } \\
\text { OLS }\end{array}$ & $\begin{array}{l}(15) \\
\text { OLS }\end{array}$ \\
\hline Distance to Fresnes & $-0.0075 * * *$ & $-0.0075^{* * *}$ & $-0.0068^{* *}$ & $-0.0071^{* * *}$ & $-0.0072 * * *$ & $-0.0077^{* * *}$ & $-0.0077^{* * *}$ & $-0.0065^{* *}$ & $-0.0072^{* *}$ & $-0.0061^{* *}$ & $-0.0084 * * *$ & $-0.0097^{* * *}$ & $-0.0075^{* * * *}$ & $-0.0075^{* * *}$ & $-0.0087^{* * *}$ \\
\hline & {$[0.0026]$} & {$[0.0027]$} & {$[0.0027]$} & {$[0.0027]$} & {$[0.0026]$} & {$[0.0028]$} & {$[0.0028]$} & {$[0.0029]$} & {$[0.0027]$} & {$[0.0028]$} & {$[0.0029]$} & {$[0.0030]$} & {$[0.0027]$} & {$[0.0027]$} & {$[0.0031]$} \\
\hline Temperature Deviations & $-4.254^{* *}$ & -4.351 & $-4.849^{* *}$ & $-4.592^{* *}$ & $-4.332^{* *}$ & $-4.161^{*}$ & $-4.140^{*}$ & $-4.340^{* * *}$ & $-4.145^{*}$ & $-5.210^{* *}$ & $-3.781^{*}$ & -2.903 & $-4.240^{*}$ & $-4.226^{* *}$ & $\begin{aligned}-3.505 \\
\end{aligned}$ \\
\hline London & & $\begin{array}{l}-0.000194 \\
{[0.00261]}\end{array}$ & & & & & & & & & & & & & \\
\hline Log Population Density 1801 & & & $\begin{array}{l}0.441 \\
{[0.469]}\end{array}$ & & & & & & & & & & & & \\
\hline Log Population Density 1831 & & & & $\begin{array}{l}0.495 \\
0.438]\end{array}$ & & & & & & & & & & & \\
\hline Log Population Density 1861 & & & & & $\begin{array}{l}0.538 \\
{[0.353]}\end{array}$ & & & & & & & & & & \\
\hline Log Iron Forges in 1789 & & & & & & 0.0131 & & & & & & & & & \\
\hline Presence of Iron Forges in 1789 & & & & & & -0.139 & & & & & & & & & \\
\hline Log Iron Forges in 1811 & & & & & & & 0.0568 & & & & & & & & \\
\hline & & & & & & & {$[0.420]$} & & & & & & & & \\
\hline Persistence of Iron Forges in 1811 & & & & & & & $\begin{array}{l}-0.260 \\
{[1.274]}\end{array}$ & & & & & & & & \\
\hline Market Integration During the French Revolution & & & & & & & & $0.751^{* *}$ & & & & & & & \\
\hline Log Share of the native population in each department 1901 & & & & & & & & & 0.0107 & & & & & & \\
\hline Log Share of the native population in each department 2010 & & & & & & & & & & 3.559 & & & & & \\
\hline Log Percentage of Conscripts who Could Read 1827-1829 & & & & & & & & & & & $\begin{array}{l}-0.0110 \\
-0.01701\end{array}$ & & & & \\
\hline Log Jews in Population 1861 & & & & & & & & & & & & & $\begin{array}{l}4.405 \\
62.76]\end{array}$ & & \\
\hline Log Protestants in Population 1861 & & & & & & & & & & & & & & $\begin{array}{l}1.471 \\
{[2.595]}\end{array}$ & \\
\hline Railroad Connection to Paris in 1860 & & & & & & & & & & & & & & & $\begin{array}{c}0.362 \\
{[0.464]}\end{array}$ \\
\hline Geographic characteristics & Yes & Yes & Yes & Yes & Yes & Yes & Yes & Yes & Yes & Yes & Yes & Yes & Yes & Yes & Yes \\
\hline Institutional characteristics & Yes & Yes & Yes & Yes & Yes & Yes & Yes & Yes & Yes & Yes & Yes & $\begin{array}{l}\text { Yes } \\
\text { Yes }\end{array}$ & Yes & Yes & Yes \\
\hline Pre-industrial development & Yes & Yes & Yes & Yes & Yes & Yes & Yes & Yes & Yes & Yes & Yes & Yes & Yes & Yes & Yes \\
\hline $\begin{array}{l}\text { Adjusted R2 } \\
\text { Observations }\end{array}$ & $\begin{array}{c}0.646 \\
89\end{array}$ & $\begin{array}{c}0.641 \\
89\end{array}$ & $\begin{array}{c}0.642 \\
85\end{array}$ & $\begin{array}{c}0.640 \\
86\end{array}$ & $\begin{array}{c}0.651 \\
89\end{array}$ & $\begin{array}{c}0.636 \\
89\end{array}$ & $\begin{array}{c}0.636 \\
89\end{array}$ & $\begin{array}{c}0.683 \\
86\end{array}$ & $\begin{array}{c}0.644 \\
87\end{array}$ & $\begin{array}{c}0.656 \\
89\end{array}$ & $\begin{array}{c}0.644 \\
89\end{array}$ & $\begin{array}{c}0.657 \\
89\end{array}$ & $\begin{array}{c}0.641 \\
89\end{array}$ & $\begin{array}{c}0.642 \\
89\end{array}$ & $\begin{array}{c}0.645 \\
89\end{array}$ \\
\hline
\end{tabular}

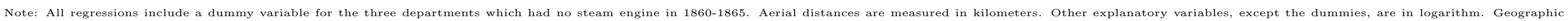

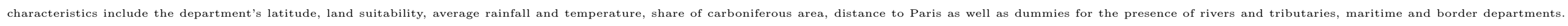

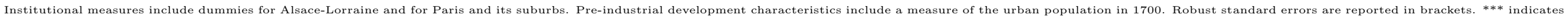
significance at the $1 \%$-level, $* *$ at the $5 \%$-level, $*$ at the $10 \%$-level 


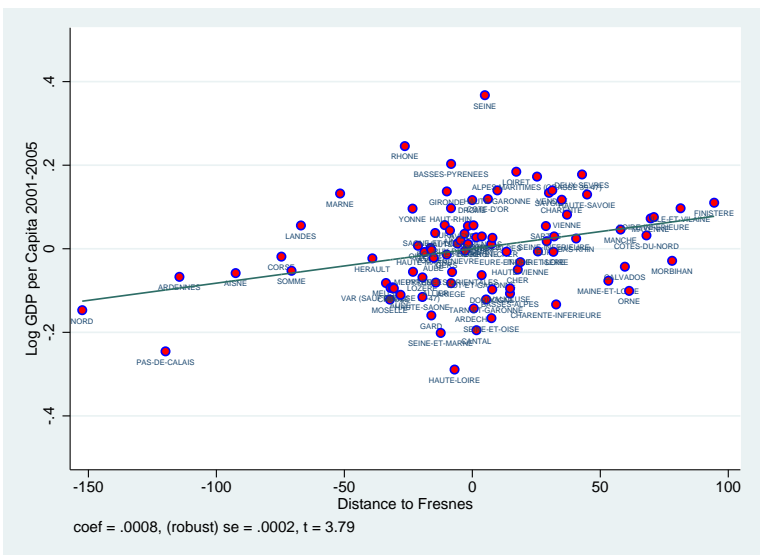

Panel A. Distance to Fresnes.

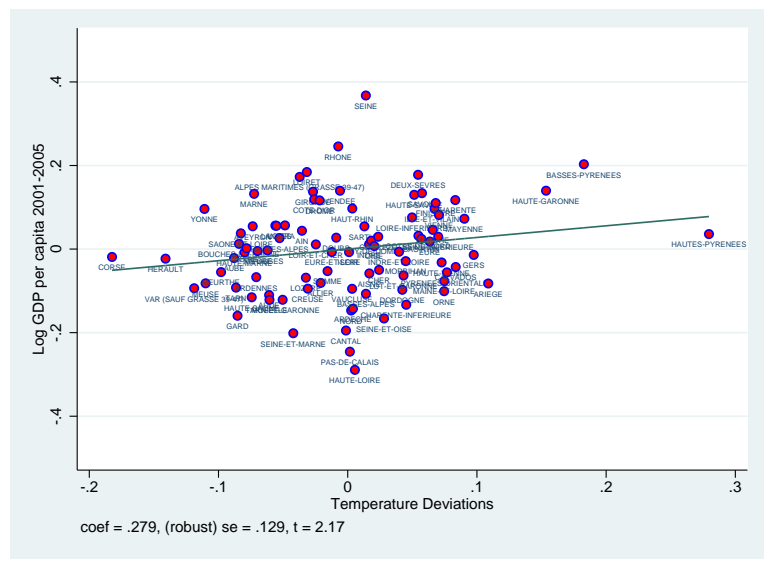

Panel B. Temperature Deviations.

Figure B.1: Reduced Form Relationship between the Instrumental Variables and log GDP per capita 2001-2005 Notes: These figures depict the partial regression line of the reduced form association between: (i) distance from Fresnes-sur-Escaut and (ii) temperature deviations in 1856-1859 period from their historical trend, and the log of GDP per capita in 2001-2005 in each French department. In both panels, the relationship accounts for geographic and institutional characteristics, as well as for pre-industrial development. 
Table B.12: Early industrialization on log GDP per capita in 1860, accounting for spatial autocorrelation

\begin{tabular}{|c|c|c|c|c|c|c|c|c|c|c|c|c|}
\hline & $\begin{array}{c}(1) \\
\text { OLS }\end{array}$ & $\begin{array}{c}(2) \\
\text { OLS }\end{array}$ & $\begin{array}{c}(3) \\
\text { GMM }\end{array}$ & $\begin{array}{c}(4) \\
\text { OLS }\end{array}$ & $\begin{array}{c}(5) \\
\text { OLS }\end{array}$ & $\begin{array}{c}6) \\
\text { GMM }\end{array}$ & $\begin{array}{c}7) \\
\text { OLS }\end{array}$ & $\begin{array}{c}(8) \\
\text { OLS }\end{array}$ & $\begin{array}{c}(9) \\
\text { GMM }\end{array}$ & $\begin{array}{l}(10) \\
\text { OLS }\end{array}$ & $\begin{array}{l}(11) \\
\text { OLS }\end{array}$ & $\begin{array}{c}(12) \\
\text { GMM }\end{array}$ \\
\hline & \multicolumn{12}{|c|}{ Log GDP per capita 1860} \\
\hline & \multicolumn{3}{|c|}{ Spatial std. errors, $50 \mathrm{~km}$ radius } & \multicolumn{3}{|c|}{ Spatial std. errors, $100 \mathrm{~km}$ radius } & \multicolumn{3}{|c|}{ Spatial std. errors, $250 \mathrm{~km}$ radius } & \multicolumn{3}{|c|}{ Spatial std. errors, $500 \mathrm{~km}$ radius } \\
\hline Log Horse Power of Steam Engines & $\begin{array}{c}0.920 \\
{[0.0162]^{* * *}}\end{array}$ & $\begin{array}{c}0.022 \\
{[0.0027]^{* * *}}\end{array}$ & $\begin{array}{c}0.0344 \\
{[0.0101]^{* * *}}\end{array}$ & $\begin{array}{c}0.920 \\
{[0.016]^{* * *}}\end{array}$ & $\begin{array}{c}0.022 \\
{[0.0019]^{* * *}}\end{array}$ & $\begin{array}{c}0.0338 \\
{[0.072]^{* * *}}\end{array}$ & $\begin{array}{c}0.920 \\
{[0.0074]^{* * *}}\end{array}$ & $\begin{array}{c}0.022 \\
{[0.0012]^{* * *}}\end{array}$ & $\begin{array}{c}0.0335 \\
{[0.0046]^{* * *}}\end{array}$ & $\begin{array}{c}0.920 \\
{[0.0052]^{* * *}}\end{array}$ & $\begin{array}{c}0.022 \\
{[0.0009]^{* * *}}\end{array}$ & $\begin{array}{c}0.0334 \\
{[0.0033]^{* * *}}\end{array}$ \\
\hline Geographic characteristics & Yes & Yes & Yes & Yes & Yes & Yes & Yes & Yes & Yes & Yes & Yes & Yes \\
\hline Institutional characteristics & Yes & Yes & Yes & Yes & Yes & Yes & Yes & Yes & Yes & Yes & Yes & Yes \\
\hline Pre-industrial development & Yes & Yes & Yes & Yes & Yes & Yes & Yes & Yes & Yes & Yes & Yes & Yes \\
\hline Observations & 87 & 87 & 87 & 87 & 87 & 87 & 87 & 87 & 87 & 87 & 87 & 87 \\
\hline
\end{tabular}

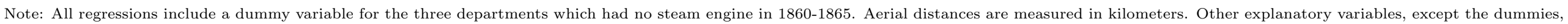

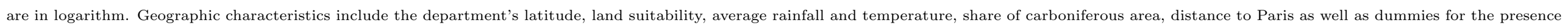

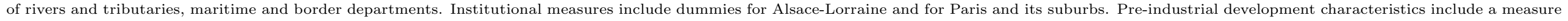
of the urban population in $1700 .{ }^{* * *}$ indicates significance at the $1 \%$-level, ${ }^{* *}$ at the $5 \%$-level, ${ }^{*}$ at the $10 \%$-level. 
Table B.13: Early industrialization on log GDP per capita in 1860, accounting for spatial autocorrelation

\begin{tabular}{|c|c|c|c|c|c|c|c|c|c|c|c|c|}
\hline & $\begin{array}{l}(1) \\
\text { OLS }\end{array}$ & $\begin{array}{c}(2) \\
\text { OLS }\end{array}$ & $\begin{array}{c}(3) \\
\text { GMM }\end{array}$ & $\begin{array}{l}(4) \\
\text { OLS }\end{array}$ & $\begin{array}{l}(5) \\
\text { OLS }\end{array}$ & $\begin{array}{c}(6) \\
\text { GMM } \\
\text { Log GDP pe }\end{array}$ & $\begin{array}{c}(7) \\
\text { OLS } \\
\text { capita } 1901\end{array}$ & $\begin{array}{c}(8) \\
\text { OLS }\end{array}$ & $\begin{array}{c}(9) \\
\text { GMM }\end{array}$ & $\begin{array}{l}(10) \\
\text { OLS }\end{array}$ & $\begin{array}{l}(11) \\
\text { OLS }\end{array}$ & $\begin{array}{c}(12) \\
\text { GMM }\end{array}$ \\
\hline & Spatial st & d. errors, 50 & $\mathrm{~m}$ radius & Spatial s & d. errors, 100 & $\mathrm{~m}$ radius & Spatial st & d. errors, 250 & $\mathrm{~m}$ radius & Spatial st & d. errors, 500 & $\mathrm{~km}$ radius \\
\hline Horse Power of Steam Engines & $\begin{array}{c}1.004 \\
{[0.0174]^{* * *}}\end{array}$ & $\begin{array}{c}0.025 \\
{[0.0058]^{* * *}}\end{array}$ & $\begin{array}{c}0.0924 \\
{[0.0230]^{* * *}}\end{array}$ & $\begin{array}{c}1.004 \\
{[0.0125]^{* * *}}\end{array}$ & $\begin{array}{c}0.025 \\
{[0.0042]^{* * *}}\end{array}$ & $\begin{array}{c}0.0925 \\
{[0.0164]^{* * *}}\end{array}$ & $\begin{array}{c}1.004 \\
{[0.0079]^{* * *}}\end{array}$ & $\begin{array}{c}0.025 \\
{[0.0026]^{* * *}}\end{array}$ & $\begin{array}{c}0.0926 \\
{[0.0104]^{* * *}}\end{array}$ & $\begin{array}{c}1.004 \\
{[0.0056]^{* * *}}\end{array}$ & $\begin{array}{c}0.025 \\
{[0.0019]^{* * *}}\end{array}$ & $\begin{array}{c}0.0926 \\
{[0.0074]^{* * *}}\end{array}$ \\
\hline Geographic characteristics & Yes & Yes & Yes & Yes & Yes & Yes & Yes & Yes & Yes & Yes & Yes & Yes \\
\hline Institutional characteristics & Yes & Yes & Yes & Yes & Yes & Yes & Yes & Yes & Yes & Yes & Yes & Yes \\
\hline Pre-industrial development & Yes & Yes & Yes & Yes & Yes & Yes & Yes & Yes & Yes & Yes & Yes & Yes \\
\hline Observations & 85 & 85 & 85 & 85 & 85 & 85 & 85 & 85 & 85 & 85 & 85 & 85 \\
\hline
\end{tabular}

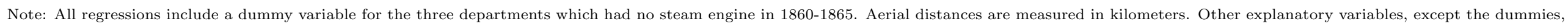

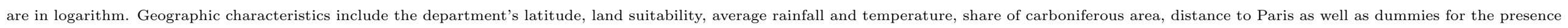

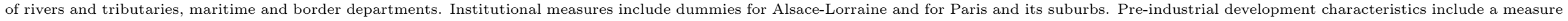
of the urban population in $1700 .{ }^{* * *}$ indicates significance at the $1 \%$-level, ${ }^{* *}$ at the $5 \%$-level, ${ }^{*}$ at the $10 \%$-level. 
Table B.14: Early industrialization on log GDP per capita in 1930, accounting for spatial autocorrelation

\begin{tabular}{|c|c|c|c|c|c|c|c|c|c|c|c|c|}
\hline & $\begin{array}{l}1) \\
\text { OLS }\end{array}$ & $\begin{array}{l}(2) \\
\text { OLS }\end{array}$ & $\begin{array}{c}(3) \\
\text { GMM }\end{array}$ & $\begin{array}{c}(4) \\
\text { OLS }\end{array}$ & $\begin{array}{c}(5) \\
\text { OLS }\end{array}$ & $\begin{array}{c}6) \\
\text { GMM } \\
\text { Log GDP per }\end{array}$ & $\begin{array}{c}\text { (7) } \\
\text { OLS } \\
\text { capita } 1930\end{array}$ & $\begin{array}{c}(8) \\
\text { OLS }\end{array}$ & $\begin{array}{c}(9) \\
\text { GMM }\end{array}$ & $\begin{array}{l}(10) \\
\text { OLS }\end{array}$ & $\begin{array}{l}\text { (11) } \\
\text { OLS }\end{array}$ & $\begin{array}{c}(12) \\
\text { GMM }\end{array}$ \\
\hline & Spatial st & d. errors, 50 & $\mathrm{~km}$ radius & Spatial st & d. errors, 100 & $\mathrm{~km}$ radius & Spatial st & 1. errors, 250 & $\mathrm{~km}$ radius & Spatial s & d. errors, 50 & $\mathrm{~km}$ radius \\
\hline Horse Power of Steam Engines & $\begin{array}{c}1.300 \\
{[0.0239]^{* * *}}\end{array}$ & $\begin{array}{c}0.0359 \\
{[0.0033]^{* * *}}\end{array}$ & $\begin{array}{c}0.0251 \\
{[0.0251]^{* * *}}\end{array}$ & $\begin{array}{c}1.300 \\
{[0.0171]^{* * *}}\end{array}$ & $\begin{array}{c}0.0359 \\
{[0.0024]^{* * *}}\end{array}$ & $\begin{array}{c}0.0252 \\
{[0.0050]^{* * *}}\end{array}$ & $\begin{array}{c}1.300 \\
{[0.0109]^{* * *}}\end{array}$ & $\begin{array}{c}0.0359 \\
{[0.0015]^{* * *}}\end{array}$ & $\begin{array}{c}0.0252 \\
{[0.0032]^{* * *}}\end{array}$ & $\begin{array}{c}1.300 \\
{[0.008]^{* * *}}\end{array}$ & $\begin{array}{c}0.0359 \\
{[0.0011]^{* * *}}\end{array}$ & $\begin{array}{c}0.0252 \\
{[0.0023]^{* * *}}\end{array}$ \\
\hline $\begin{array}{l}\text { Geographic characteristics } \\
\text { Institutional characteristics } \\
\text { Pre-industrial development }\end{array}$ & $\begin{array}{l}\text { Yes } \\
\text { Yes } \\
\text { Yes }\end{array}$ & $\begin{array}{l}\text { Yes } \\
\text { Yes } \\
\text { Yes }\end{array}$ & $\begin{array}{l}\text { Yes } \\
\text { Yes } \\
\text { Yes }\end{array}$ & $\begin{array}{l}\text { Yes } \\
\text { Yes } \\
\text { Yes }\end{array}$ & $\begin{array}{l}\text { Yes } \\
\text { Yes } \\
\text { Yes }\end{array}$ & $\begin{array}{l}\text { Yes } \\
\text { Yes } \\
\text { Yes }\end{array}$ & $\begin{array}{l}\text { Yes } \\
\text { Yes } \\
\text { Yes }\end{array}$ & $\begin{array}{l}\text { Yes } \\
\text { Yes } \\
\text { Yes }\end{array}$ & $\begin{array}{l}\text { Yes } \\
\text { Yes } \\
\text { Yes }\end{array}$ & $\begin{array}{l}\text { Yes } \\
\text { Yes } \\
\text { Yes }\end{array}$ & $\begin{array}{l}\text { Yes } \\
\text { Yes } \\
\text { Yes }\end{array}$ & $\begin{array}{l}\text { Yes } \\
\text { Yes } \\
\text { Yes }\end{array}$ \\
\hline Observations & 87 & 87 & 87 & 87 & 87 & 87 & 87 & 87 & 87 & 87 & 87 & 87 \\
\hline
\end{tabular}

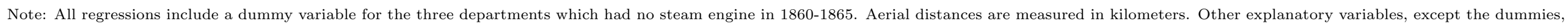

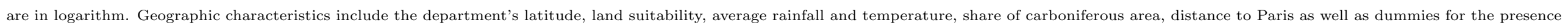

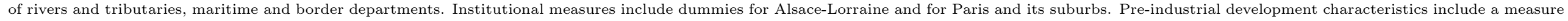
of the urban population in $1700 .{ }^{* * *}$ indicates significance at the $1 \%$-level, ${ }^{* *}$ at the $5 \%$-level, ${ }^{*}$ at the $10 \%$-level. 
Table B.15: Early industrialization and log GDP per capita in 2001-2005, accounting for spatial autocorrelation

\begin{tabular}{|c|c|c|c|c|c|c|c|c|c|c|c|c|}
\hline & $\begin{array}{ll}(1) \\
\text { OLS }\end{array}$ & $\begin{array}{l}(2) \\
\text { OLS }\end{array}$ & $\begin{array}{c}(3) \\
\text { GMM }\end{array}$ & $\begin{array}{ll}(4) \\
\text { OLS }\end{array}$ & $\begin{array}{ll}(5) \\
\text { OLS }\end{array}$ & $\begin{array}{c}(6) \\
\text { GMM }\end{array}$ & $\begin{array}{l}(7) \\
\text { OLS }\end{array}$ & $\begin{array}{c}(8) \\
\text { OLS }\end{array}$ & $\begin{array}{c}(9) \\
\text { GMM }\end{array}$ & $\begin{array}{ll}(10) \\
\text { OLS }\end{array}$ & $\begin{array}{ll}(11) \\
\text { OLS }\end{array}$ & $(12)$ \\
\hline & \multirow{2}{*}{\multicolumn{12}{|c|}{ Log GDP per capita 2001-2005 }} \\
\hline & Spatial std & errors, 5 & $\mathrm{~km}$ radius & Spatial std. & & & & & $50 \mathrm{~km}$ radius & Spatial std & errors, 5 & $0 \mathrm{~km}$ radius \\
\hline Horse Power of Steam Engines & $\begin{array}{c}0.457 \\
{[0.0091]^{* * *}}\end{array}$ & $\begin{array}{c}0.0007 \\
{[0.0035]}\end{array}$ & $\begin{array}{c}-0.0619 \\
{[0.0080]^{* * *}}\end{array}$ & $\begin{array}{c}0.4570 \\
{[0.007]^{* * *}}\end{array}$ & $\begin{array}{c}0.0007 \\
{[0.0025]}\end{array}$ & $\begin{array}{c}-0.0622 \\
{[0.0056]^{* * *}}\end{array}$ & $\begin{array}{c}0.457 \\
{[0.0042]^{* * *}}\end{array}$ & $\begin{array}{c}0.0007 \\
{[0.0016]}\end{array}$ & $\begin{array}{c}-0.0624 \\
{[0.0036]^{* * *}}\end{array}$ & $\begin{array}{c}0.4568 \\
{[0.0030]^{* * *}}\end{array}$ & $\begin{array}{c}0.0007 \\
{[0.0011]}\end{array}$ & $\begin{array}{c}-0.0625 \\
{[0.0025]^{* * *}}\end{array}$ \\
\hline Geographic characteristics & Yes & Yes & Yes & Yes & Yes & Yes & Yes & Yes & Yes & Yes & Yes & Yes \\
\hline Institutional characteristics & Yes & Yes & Yes & Yes & Yes & Yes & Yes & Yes & Yes & Yes & Yes & Yes \\
\hline Pre-industrial development & Yes & Yes & Yes & Yes & Yes & Yes & Yes & Yes & Yes & Yes & Yes & Yes \\
\hline Observations & 89 & 89 & 89 & 89 & 89 & 89 & 89 & 89 & 89 & 89 & 89 & 89 \\
\hline
\end{tabular}

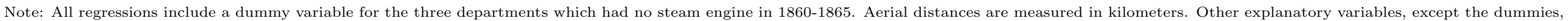

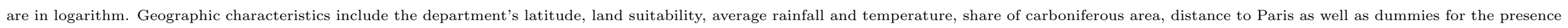

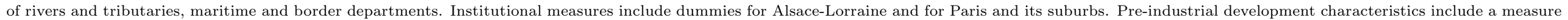
of the urban population in $1700 .{ }^{* * *}$ indicates significance at the $1 \%$-level, ${ }^{* *}$ at the $5 \%$-level, ${ }^{*}$ at the $10 \%$-level. 
Table B.16: Industrialization and income per capita, $1860 \& 1901$, clustering by the current regional divisions of the territory

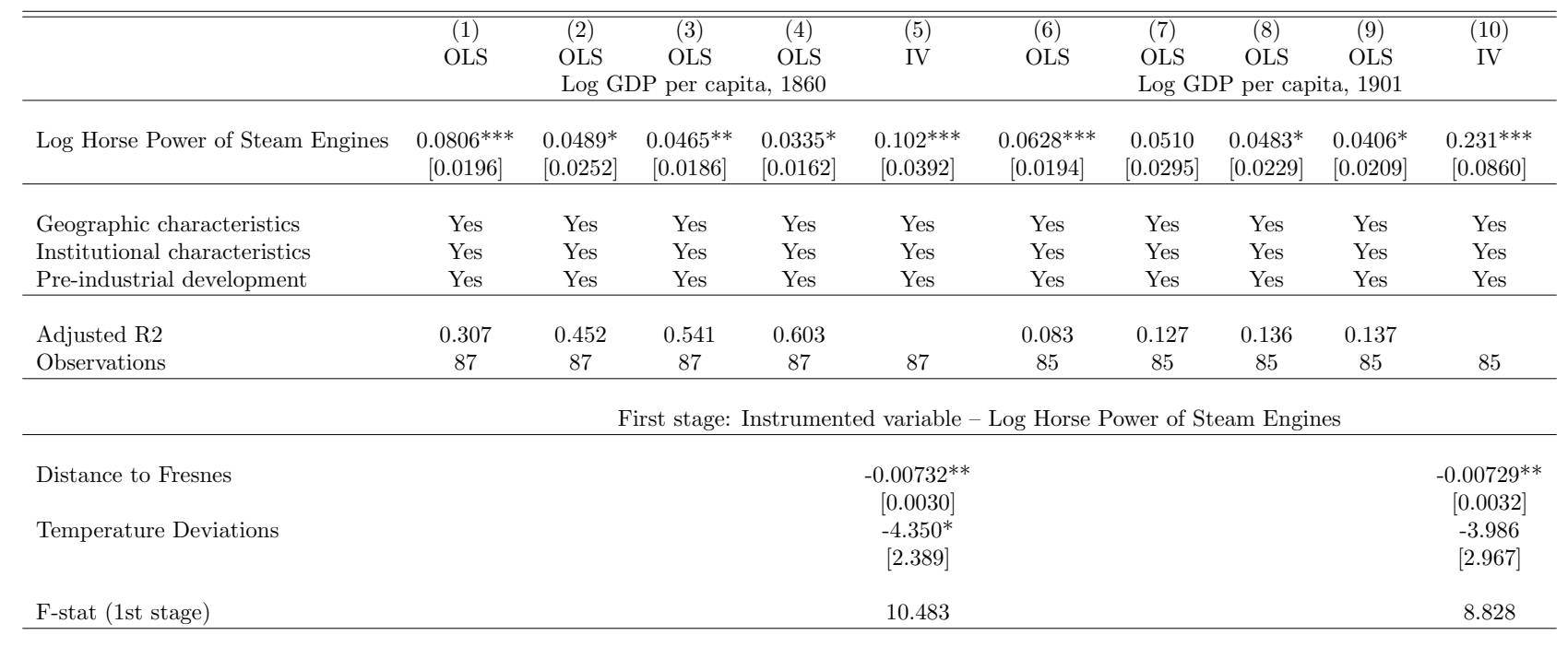

Note: All regressions include a dummy variable for the three departments which had no steam engine in 1860-1865. The Alsace-Lorraine variable is omitted from the regressions since the Alsace-Lorraine region was not part of France between 1871 and 1914. Aerial distances are measured in kilometers. Other explanatory variables, except the dummies, and the dependent variables are in logarithm. Robust standard errors are reported in brackets. Geographic characteristics include the department's latitude, land suitability, average rainfall and temperature, share of carboniferous area, distance to Paris as well as dummies for the presence of rivers and tributaries, maritime and border departments. Institutional measures include dummies for Alsace-Lorraine and for Paris and its suburbs. Pre-industrial development characteristics include a measure of the urban population in 1700 . $* * *$ indicates significance at the $1 \%$-level, ** at the $5 \%$-level, * at the $10 \%$-level. 
Table B.17: Industrialization and income per capita, 1930 \& 2001-2005, clustering by the current regional divisions of the territory

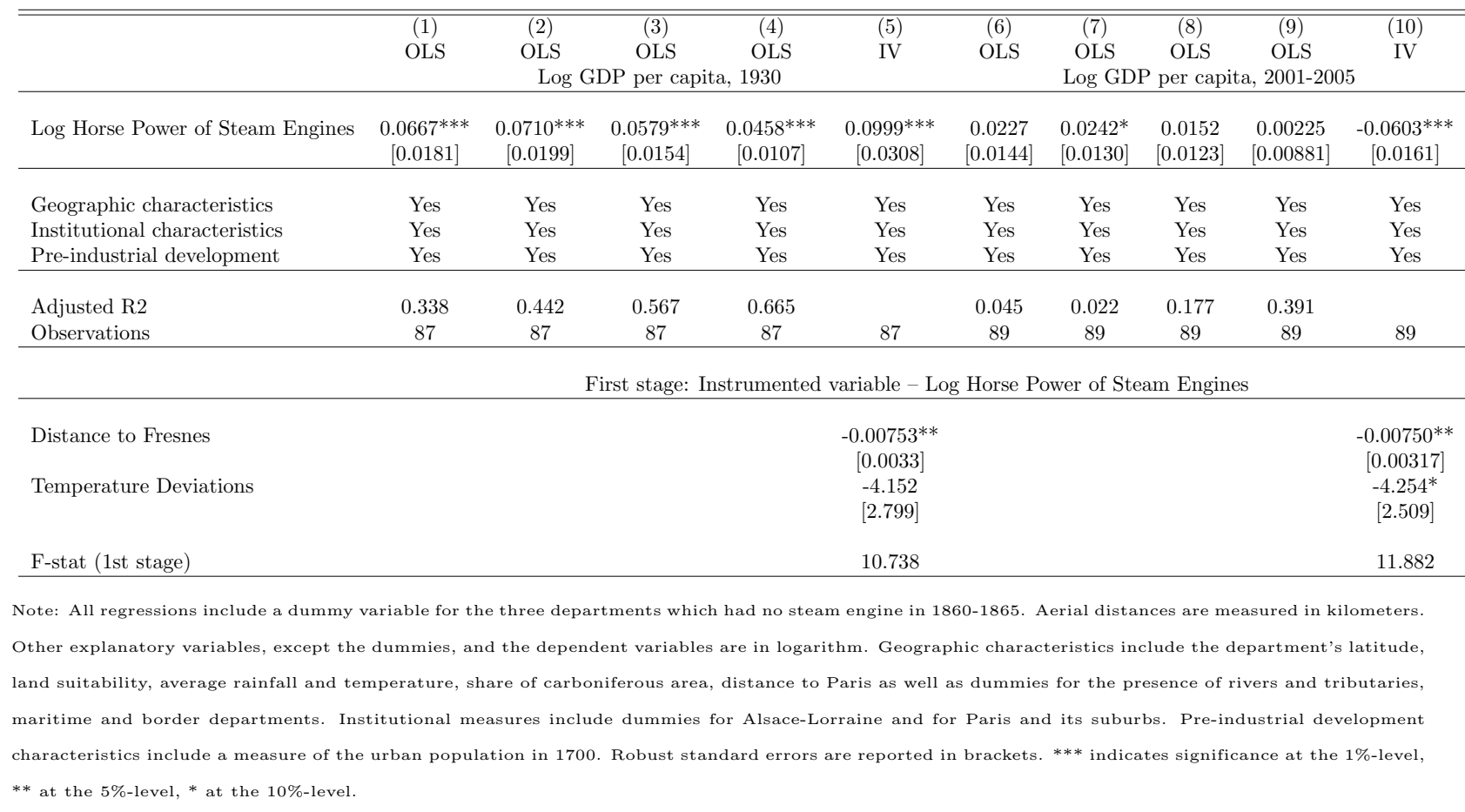


Table B.18: Industrialization and income per capita using the current regional divisions of the French territory

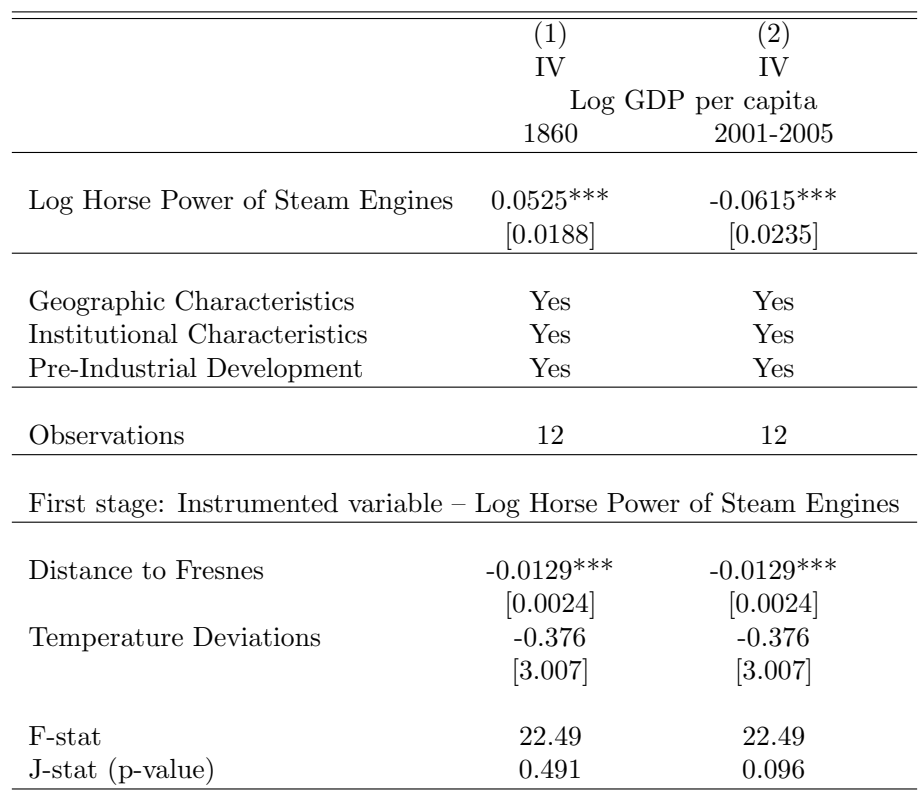

Note: Aerial distances are measured in kilometers. Other explanatory variables, except the dummies, and the dependent variables are in logarithm. Geographic characteristics include the department's latitude, land suitability, average rainfall and temperature, share of carboniferous area, distance to Paris as well as dummies for the presence of rivers and tributaries, maritime and border departments. Institutional measures include dummies for Alsace-Lorraine and for Paris and its suburbs. Pre-industrial development characteristics include a measure of the urban population in 1700 . Robust standard errors are reported in brackets. $* * *$ indicates significance at the $1 \%$-level, $* *$ at the $5 \%$-level, $*$ at the $10 \%$-level. 
Table B.19: Industrialization and income per capita, accounting for income per capita in 1860

\begin{tabular}{|c|c|c|c|c|}
\hline & (1) & $(2)$ & $(3)$ & (4) \\
\hline & IV & IV & IV & IV \\
\hline & \multicolumn{2}{|c|}{ Log GDP per capita 1930} & \multicolumn{2}{|c|}{ Log GDP per capita $2001-5$} \\
\hline $\begin{array}{l}\text { Log Horse Power of Steam Engines } \\
\text { GDP per capita in } 1860\end{array}$ & $\begin{array}{c}0.0909^{* * *} \\
{[0.0273]}\end{array}$ & $\begin{array}{c}0.0592^{* *} \\
{[0.0249]} \\
0.307 * * * \\
{[0.0929]}\end{array}$ & $\begin{array}{c}-0.0620^{* * *} \\
{[0.0225]}\end{array}$ & $\begin{array}{c}-0.0743^{* *} \\
{[0.0320]} \\
0.149 \\
{[0.104]}\end{array}$ \\
\hline $\begin{array}{l}\text { Geographic characteristics } \\
\text { Institutional characteristics } \\
\text { Pre-industrial development }\end{array}$ & $\begin{array}{l}\text { Yes } \\
\text { Yes } \\
\text { Yes }\end{array}$ & $\begin{array}{l}\text { Yes } \\
\text { Yes } \\
\text { Yes }\end{array}$ & $\begin{array}{l}\text { Yes } \\
\text { Yes } \\
\text { Yes }\end{array}$ & $\begin{array}{l}\text { Yes } \\
\text { Yes } \\
\text { Yes }\end{array}$ \\
\hline Observations & 87 & 87 & 89 & 87 \\
\hline \multicolumn{5}{|c|}{ First stage: Instrumented variable - Log Horse Power of Steam Engines } \\
\hline Distance to Fresnes & $\begin{array}{c}-0.00645^{* *} \\
{[0.00250]}\end{array}$ & $\begin{array}{c}-0.00524^{*} \\
{[0.00268]}\end{array}$ & $\begin{array}{c}-0.00644^{* *} \\
{[0.00251]}\end{array}$ & $\begin{array}{c}-0.00524^{*} \\
{[0.00268]}\end{array}$ \\
\hline Temperature Deviations & $\begin{array}{c}-4.857^{* *} \\
{[2.428]}\end{array}$ & $\begin{array}{c}-4.794^{*} \\
{[2.476]}\end{array}$ & $\begin{array}{c}-4.836^{* *} \\
{[2.306]}\end{array}$ & $\begin{array}{c}-4.794^{*} \\
{[2.476]}\end{array}$ \\
\hline F-stat (1st stage) & 12.302 & 8.161 & 14.403 & 8.161 \\
\hline J-stat (p-value) & 0.082 & 0.083 & 0.273 & 0.178 \\
\hline
\end{tabular}

Note: All regressions include a dummy variable for the three departments which had no steam engine in 1860-1865. Aerial distances are measured in kilometers. Other explanatory variables, except the dummies, and the dependent variables are in logarithm. Robust standard errors are reported in brackets.

Geographic characteristics include the department's latitude, land suitability, average rainfall and temperature, share of carboniferous area, distance to Paris as well as dummies for the presence of rivers and tributaries, maritime and border departments. Institutional measures include dummies for Alsace-Lorraine and for Paris and its suburbs. Pre-industrial development characteristics include a measure of the urban population in 1700 . *** indicates significance at the $1 \%$-level, ** at the $5 \%$-level, * at the $10 \%$-level. 
Table B.20: Industrialization and income per capita, accounting for population density in the $19^{\text {th }}$ century

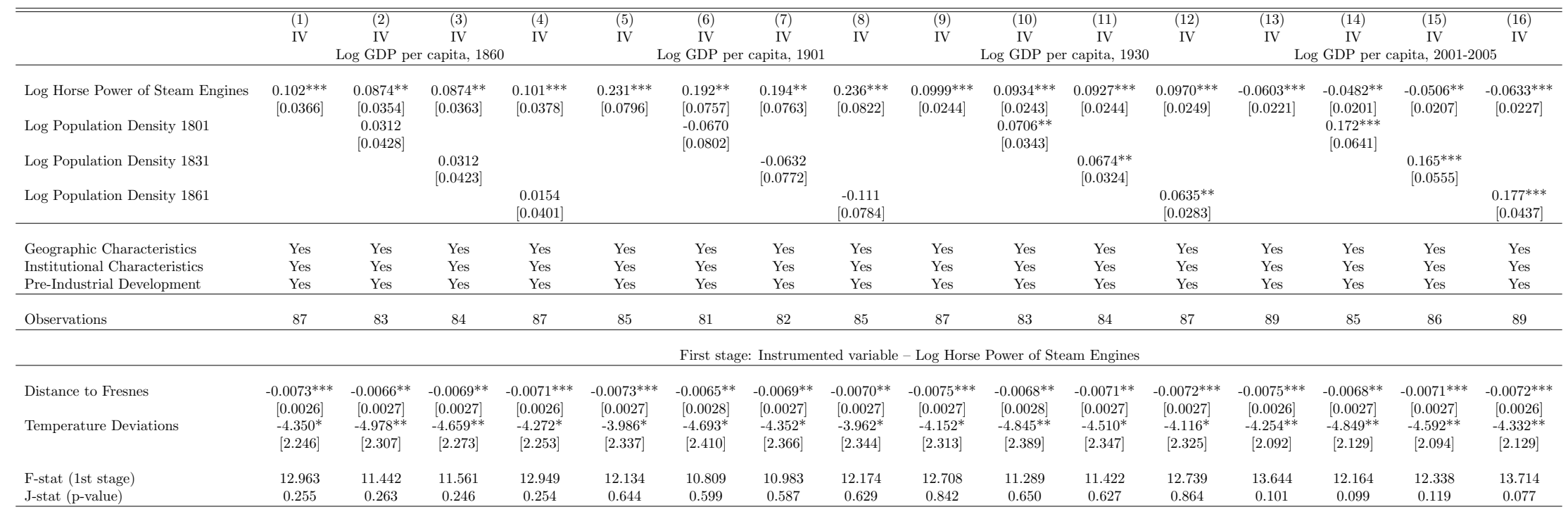

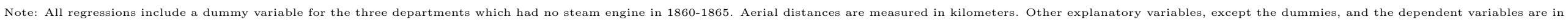

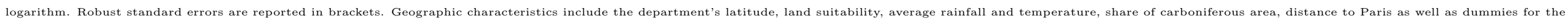

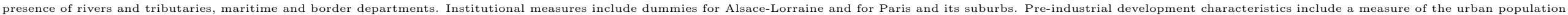
in $1700 .{ }^{* * *}$ indicates significance at the $1 \%$-level, $* *$ at the $5 \%$-level, * at the $10 \%$-level. 
Table B.21: Industrialization and income per capita, accounting for the number of universities in 1700

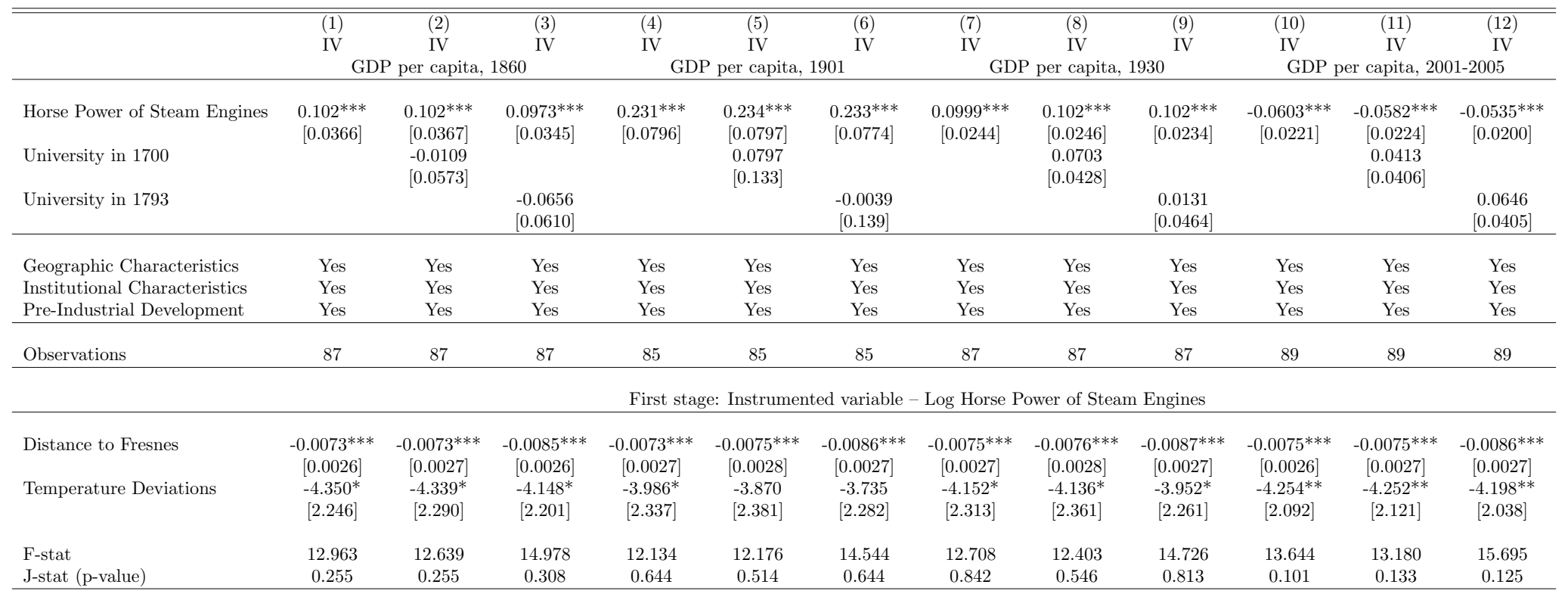

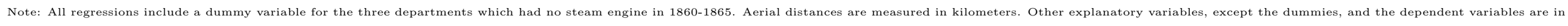

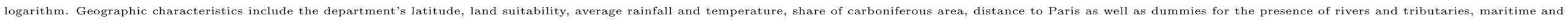

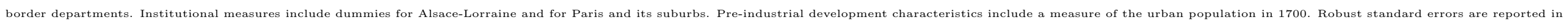
brackets. ${ }^{* * *}$ indicates significance at the $1 \%$-level, ${ }^{* *}$ at the $5 \%$-level, $*$ at the $10 \%$-level. 
Table B.22: Industrialization and income per capita, accounting for the conscripts' ability to read before 1840

\begin{tabular}{|c|c|c|c|c|c|c|c|c|c|c|c|c|}
\hline & \multirow{2}{*}{\multicolumn{3}{|c|}{$\begin{array}{l}(1) \\
\text { GDP per capita, } 1860\end{array}$}} & \multirow{2}{*}{\multicolumn{3}{|c|}{$\begin{array}{l}(4) \\
\text { GDP per capita, } 1901\end{array}$}} & \multirow{2}{*}{\multicolumn{3}{|c|}{$\begin{array}{l}(7) \\
\text { GDP per capita, } 1930\end{array}$}} & \multirow{2}{*}{\multicolumn{3}{|c|}{$\begin{array}{l}(10) \\
\text { GDP per capita, }\end{array}$}} \\
\hline & & & & & & & & & & & & \\
\hline & IV & IV & IV & IV & IV & IV & IV & IV & IV & IV & IV & IV \\
\hline \multirow{3}{*}{$\begin{array}{l}\text { Horse Power of Steam Engines } \\
\text { Share of Conscripts who Could Read 1827-1829 } \\
\text { Share of Conscripts who Could Read 1831-1835 }\end{array}$} & $\begin{array}{c}0.102^{* * *} \\
{[0.0366]}\end{array}$ & $\begin{array}{c}0.107^{* * *} \\
{[0.0369]}\end{array}$ & $\begin{array}{c}0.113^{* * *} \\
{[0.0375]}\end{array}$ & $\begin{array}{c}0.231^{* * *} \\
{[0.0796]}\end{array}$ & $\begin{array}{c}0.237^{* * *} \\
{[0.0770]}\end{array}$ & $\begin{array}{c}0.241^{* * *} \\
{[0.0745]}\end{array}$ & \multirow[t]{3}{*}{$\begin{array}{c}0.0999^{* * *} \\
{[0.0244]}\end{array}$} & \multirow{3}{*}{$\begin{array}{c}0.101^{* * *} \\
{[0.0242]} \\
0.0011 \\
{[0.00174]}\end{array}$} & $\begin{array}{c}0.102^{* * *} \\
{[0.0243]}\end{array}$ & \multirow[t]{3}{*}{$\begin{array}{c}-0.0603^{* * *} \\
{[0.0221]}\end{array}$} & \multirow{3}{*}{$\begin{array}{c}-0.0627^{* * *} \\
{[0.0224]} \\
-0.00004 \\
{[0.0019]}\end{array}$} & $\begin{array}{c}-0.0660^{* * *} \\
{[0.0220]}\end{array}$ \\
\hline & & $\begin{array}{c}0.0013 \\
{[0.00215]}\end{array}$ & & & $\begin{array}{c}0.0040 \\
{[0.00425]}\end{array}$ & & & & & & & \\
\hline & & & $\begin{array}{c}0.0009 \\
{[0.00262]}\end{array}$ & & & $\begin{array}{c}0.0032 \\
{[0.00418]}\end{array}$ & & & $\begin{array}{c}0.0007 \\
{[0.00167]}\end{array}$ & & & $\begin{array}{c}-0.0032^{* *} \\
{[0.0015]}\end{array}$ \\
\hline Geographic Characteristics & Yes & Yes & Yes & Yes & Yes & Yes & Yes & Yes & Yes & Yes & Yes & Yes \\
\hline Institutional Characteristics & Yes & Yes & Yes & Yes & Yes & Yes & Yes & Yes & Yes & Yes & Yes & Yes \\
\hline Pre-Industrial Development & Yes & Yes & Yes & Yes & Yes & Yes & Yes & Yes & Yes & Yes & Yes & Yes \\
\hline \multirow[t]{2}{*}{ Observations } & 87 & 87 & 87 & 85 & 85 & 85 & 87 & 87 & 87 & 89 & 89 & 89 \\
\hline & \multicolumn{12}{|c|}{ First stage: Instrumented variable - Log Horse Power of Steam Engines } \\
\hline Distance to Fresnes & $\begin{array}{c}-0.0073^{* * *} \\
{[0.0026]}\end{array}$ & $\begin{array}{c}-0.0085^{* * *} \\
{[0.0030]}\end{array}$ & $\begin{array}{c}-0.0102^{* * *} \\
{[0.0032]}\end{array}$ & $\begin{array}{c}-0.0073^{* * *} \\
{[0.0027]}\end{array}$ & $\begin{array}{c}-0.0082^{* * *} \\
{[0.0030]}\end{array}$ & $\begin{array}{c}-0.0100^{* * *} \\
{[0.0033]}\end{array}$ & $\begin{array}{c}-0.0075^{* * *} \\
{[0.0027]}\end{array}$ & $\begin{array}{c}-0.0087^{* * *} \\
{[0.0030]}\end{array}$ & $\begin{array}{c}-0.0106^{* * *} \\
{[0.0033]}\end{array}$ & $\begin{array}{c}-0.0075^{* * *} \\
{[0.0026]}\end{array}$ & $\begin{array}{c}-0.0084^{* * *} \\
{[0.0029]}\end{array}$ & $\begin{array}{c}-0.0097^{* * *} \\
{[0.0030]}\end{array}$ \\
\hline Temperature Deviations & $\begin{array}{c}-4.350^{*} \\
{[2.246]}\end{array}$ & $\begin{array}{l}-3.504 \\
{[2.442]}\end{array}$ & $\begin{array}{l}-2.109 \\
{[2.709]}\end{array}$ & $\begin{array}{c}-3.986^{*} \\
{[2.337]}\end{array}$ & $\begin{array}{l}-3.322 \\
{[2.504]}\end{array}$ & $\begin{array}{l}-1.906 \\
{[2.741]}\end{array}$ & $\begin{array}{c}-4.152^{*} \\
{[2.313]}\end{array}$ & $\begin{array}{l}-3.282 \\
{[2.497]}\end{array}$ & $\begin{array}{l}-1.762 \\
{[2.737]}\end{array}$ & $\begin{array}{c}-4.254^{* *} \\
{[2.092]}\end{array}$ & $\begin{array}{c}-3.781^{*} \\
{[2.175]}\end{array}$ & $\begin{array}{l}-2.903 \\
{[2.311]}\end{array}$ \\
\hline F-stat (1st stage) & 12.963 & 13.352 & 14.769 & 12.134 & 12.294 & 13.646 & 12.708 & 13.114 & 14.480 & 13.644 & 13.739 & 14.953 \\
\hline J-stat (p-value) & 0.255 & 0.347 & 0.349 & 0.644 & 0.896 & 0.891 & 0.842 & 0.953 & 0.988 & 0.101 & 0.101 & 0.342 \\
\hline
\end{tabular}

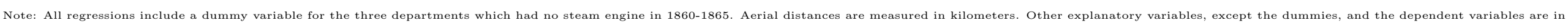

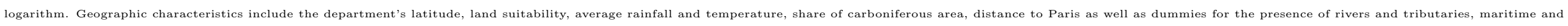

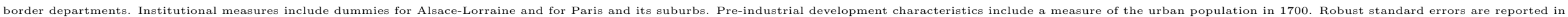
brackets. ${ }^{* * *}$ indicates significance at the $1 \%$-level, ${ }^{* *}$ at the $5 \%$-level, $*$ at the $10 \%$-level 
Table B.23: Industrialization and income per capita, accounting for the share of grooms who signed their marriage license before 1790

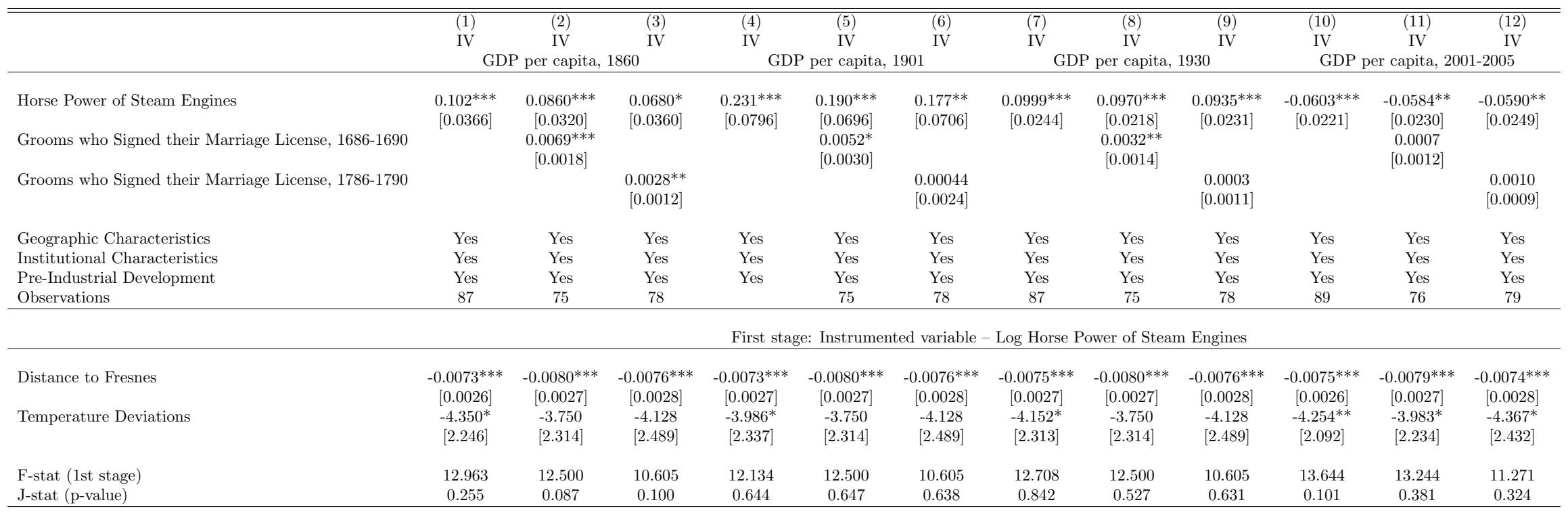

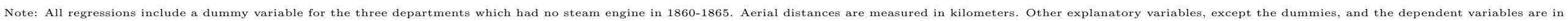

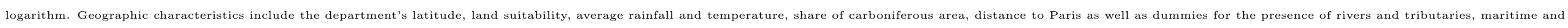

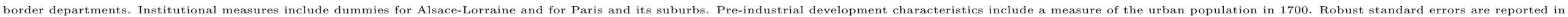
brackets. ${ }^{* * *}$ indicates significance at the $1 \%$-level, $* *$ at the $5 \%$-level, $*$ at the $10 \%$-level 
Table B.24: Industrialization and income per capita, accounting for religious minorities in 1861

\begin{tabular}{|c|c|c|c|c|c|c|c|c|c|c|c|c|c|c|c|c|}
\hline & $\begin{array}{l}(1) \\
\text { IV }\end{array}$ & $\begin{array}{l}(2) \\
\text { IV }\end{array}$ & $\begin{array}{l}\text { (3) } \\
\text { IV }\end{array}$ & $\begin{array}{l}(4) \\
\text { IV }\end{array}$ & $\begin{array}{l}(5) \\
\text { IV }\end{array}$ & $\begin{array}{l}(6) \\
\text { IV }\end{array}$ & $\begin{array}{l}\text { (7) } \\
\text { IV }\end{array}$ & $\begin{array}{l}(8) \\
\text { IV }\end{array}$ & $\begin{array}{l}9) \\
\text { IV }\end{array}$ & $\begin{array}{l}\text { (10) } \\
\text { IV }\end{array}$ & $\begin{array}{l}(11) \\
\text { IV }\end{array}$ & $\begin{array}{l}(12) \\
\text { IV }\end{array}$ & $\begin{array}{l}(13) \\
\text { IV }\end{array}$ & $\begin{array}{c}\text { IV } \\
\text { IV }\end{array}$ & $\begin{array}{l}(15) \\
\text { IV }\end{array}$ & $\begin{array}{l}(16) \\
\text { IV }\end{array}$ \\
\hline $\begin{array}{l}\text { Horse Power of Steam Engines } \\
\text { Jews in Population } 1861\end{array}$ & $\begin{array}{l}0.102^{* * *} \\
{[0.0366]}\end{array}$ & $\begin{array}{l}0.104^{* * *} \\
{[0.0383]} \\
-1.106 \\
{[3.756]}\end{array}$ & $\begin{array}{l}-0.383 \\
{[0.358]}\end{array}$ & $\begin{array}{c}0.107 * * * \\
{[0.0388]} \\
2.005 \\
{[4.653]} \\
-0.465 \\
{[0.396]}\end{array}$ & $\begin{array}{l}0.2311^{* * *} \\
{[0.0796]}\end{array}$ & $\begin{array}{c}0.222 * * * \\
{[0.0782]} \\
26.42 \\
{[42.97]}\end{array}$ & $\begin{array}{c}-1.550^{*} \\
{[0.893]}\end{array}$ & $\begin{array}{c}0.240^{* * *} \\
{[0.0841]} \\
26.12 \\
{[44.37]} \\
-1.544^{*} \\
{[0.889]}\end{array}$ & $\begin{array}{c}0.0999 * * * \\
{[0.0244]}\end{array}$ & $\begin{array}{c}0.0908^{* * *} \\
{[0.0238]} \\
23.49^{* * *} \\
{[8.148]}\end{array}$ & $\begin{array}{c} \\
-0.877^{* * *} \\
{[0.263]}\end{array}$ & $\begin{array}{c}0.0965^{* * * *} \\
{[0.0241]} \\
30.818^{* * *} \\
{[8.386]} \\
-1.037^{* * *} \\
{[0.207]}\end{array}$ & $\begin{array}{c}-0.0600 * * * * \\
{[0.0221]}\end{array}$ & $\begin{array}{c}-0.06060^{* * *} \\
{[0.0220]} \\
18.05^{*} \\
{[10.31]}\end{array}$ & $\begin{array}{c}-0.06022^{* * *} \\
{[0.0223]}\end{array}$ & $\begin{array}{c}-0.0593^{* * *} \\
{[0.0219]} \\
22.22^{* *} \\
{[9.832]} \\
-0.422 \\
{[0.298]}\end{array}$ \\
\hline $\begin{array}{l}\text { Geographic Characteristics } \\
\text { Institutional Characteristics } \\
\text { Pre-Industrial Development }\end{array}$ & $\begin{array}{l}\text { Yes } \\
\text { Yes } \\
\text { Yes }\end{array}$ & $\begin{array}{l}\text { Yes } \\
\text { Yes } \\
\text { Yes }\end{array}$ & $\begin{array}{l}\text { Yes } \\
\text { Yes } \\
\text { Yes }\end{array}$ & $\begin{array}{l}\text { Yes } \\
\text { Yes } \\
\text { Yes }\end{array}$ & $\begin{array}{l}\text { Yes } \\
\text { Yes } \\
\text { Yes }\end{array}$ & $\begin{array}{l}\text { Yes } \\
\text { Yes } \\
\text { Yes }\end{array}$ & $\begin{array}{l}\text { Yes } \\
\text { Yes } \\
\text { Yes }\end{array}$ & $\begin{array}{l}\text { Yes } \\
\text { Yes } \\
\text { Yes }\end{array}$ & $\begin{array}{l}\text { Yes } \\
\text { Yes } \\
\text { Yes }\end{array}$ & $\begin{array}{l}\text { Yes } \\
\text { Yes } \\
\text { Yes }\end{array}$ & $\begin{array}{l}\text { Yes } \\
\text { Yes } \\
\text { Yes }\end{array}$ & $\begin{array}{l}\text { Yes } \\
\text { Yes } \\
\text { Yes }\end{array}$ & $\begin{array}{l}\text { Yes } \\
\text { Yes } \\
\text { Yes }\end{array}$ & $\begin{array}{l}\text { Yes } \\
\text { Yes } \\
\text { Yes }\end{array}$ & $\begin{array}{l}\text { Yes } \\
\text { Yes } \\
\text { Yes }\end{array}$ & $\begin{array}{l}\text { Yes } \\
\text { Yes } \\
\text { Yes }\end{array}$ \\
\hline Observations & 87 & 87 & 87 & 87 & 85 & 85 & 85 & 85 & 87 & 87 & 87 & 87 & 89 & 89 & 89 & 89 \\
\hline & & & & & & First sta & e: Instrumen & ted variable & - Log Horse P & ower of Stear & n Engines & & & & & \\
\hline Temperature Deviations & $\begin{array}{c}-0.0073^{* * *} \\
{[0.0026]} \\
-4.350^{*} \\
{[2.246]}\end{array}$ & $\begin{array}{c}-0.0076^{* * *} \\
{[0.0028]} \\
-4.050^{*} \\
{[2.409]}\end{array}$ & $\begin{array}{c}-0.0075^{* * *} \\
{[0.0027]} \\
-4.060^{*} \\
{[2.331]}\end{array}$ & $\begin{array}{c}-0.0075 * * * \\
{[0.0027]} \\
-4.020 \\
{[2.421]}\end{array}$ & $\begin{array}{c}-0.0073^{* * *} \\
{[0.0027]} \\
-3.986^{*} \\
{[2.337]}\end{array}$ & $\begin{array}{c}-0.0078^{* * *} \\
{[0.0029]} \\
-3.108 \\
{[2.550]}\end{array}$ & $\begin{array}{c}-0.0071 * * * \\
{[0.0027]} \\
-3.684 \\
{[2.400]}\end{array}$ & $\begin{array}{c}-0.0076^{* * *} \\
{[0.0028]} \\
-2.840 \\
{[2.599]}\end{array}$ & $\begin{array}{c}-0.0075^{* * *} \\
{[0.0027]} \\
-4.152^{*} \\
{[2.313]}\end{array}$ & $\begin{array}{c}-0.0076^{* * *} \\
{[0.0028]} \\
-4.013 \\
{[2.526]}\end{array}$ & $\begin{array}{c}-0.0075^{* * *} \\
{[0.0027]} \\
-4.046^{*} \\
{[2.352]}\end{array}$ & $\begin{array}{c}-0.0075 * * * \\
{[0.0028]} \\
-3.986 \\
{[2.548]}\end{array}$ & $\begin{array}{c}-0.0075 * * * \\
{[0.0026]} \\
-4.254 * * \\
{[2.092]}\end{array}$ & $\begin{array}{c}-0.0075^{* * *} \\
{[0.0027]} \\
-4.240^{*} \\
{[2.138]}\end{array}$ & $\begin{array}{c}-0.0075 * * * \\
{[0.0026]} \\
-4.222^{* *} \\
{[2.103]}\end{array}$ & $\begin{array}{c}-0.0074^{* * *} \\
{[0.0027]} \\
-4.262^{*} \\
{[2.140]}\end{array}$ \\
\hline $\begin{array}{l}\text { F-stat } \\
\text { J-stat (p-value) }\end{array}$ & $\begin{array}{c}12.963 \\
0.255\end{array}$ & $\begin{array}{c}12.545 \\
0.254\end{array}$ & $\begin{array}{c}12.182 \\
0.305\end{array}$ & $\begin{array}{c}12.020 \\
0.244\end{array}$ & $\begin{array}{c}12.134 \\
0.644\end{array}$ & $\begin{array}{c}10.498 \\
0.480\end{array}$ & $\begin{array}{c}10.942 \\
0.692\end{array}$ & $\begin{array}{l}9.685 \\
0.530\end{array}$ & $\begin{array}{c}12.708 \\
0.842\end{array}$ & $\begin{array}{c}12.111 \\
0.523\end{array}$ & $\begin{array}{c}11.986 \\
0.905\end{array}$ & $\begin{array}{c}11.603 \\
0.487\end{array}$ & $\begin{array}{c}13.644 \\
0.101\end{array}$ & $\begin{array}{c}13.515 \\
0.160\end{array}$ & $\begin{array}{c}13.249 \\
0.100\end{array}$ & $\begin{array}{c}13.154 \\
0.170\end{array}$ \\
\hline
\end{tabular}

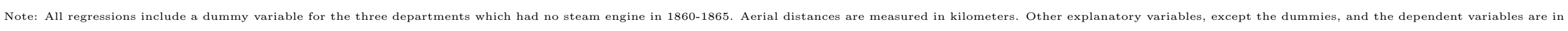

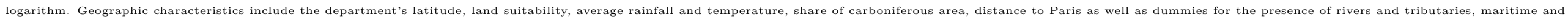

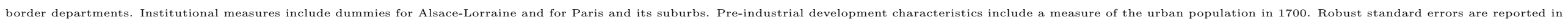
brackets. ${ }^{* * *}$ indicates significance at the $1 \%$-level, ${ }^{* *}$ at the $5 \%$-level, ${ }^{*}$ at the $10 \%$-level. 
Table B.25: Industrialization and income per capita, accounting for iron forges before 1811

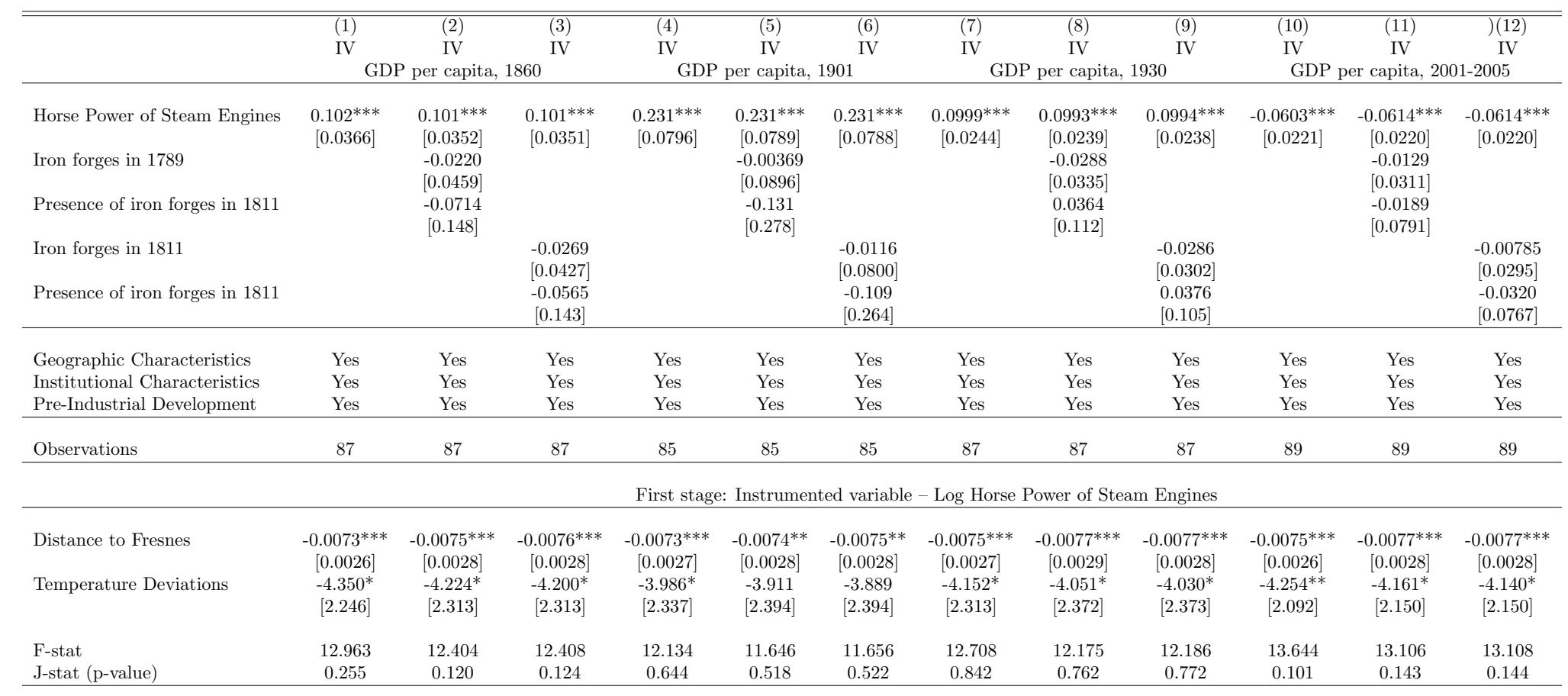

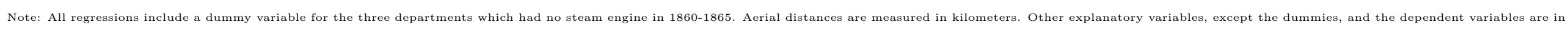

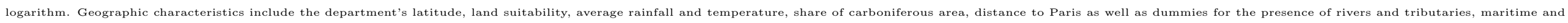

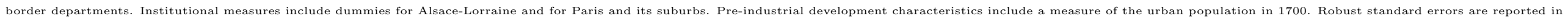
brackets. ${ }^{* * *}$ indicates significance at the $1 \%$-level, ${ }^{* *}$ at the $5 \%$-level, $*$ at the $10 \%$-level 
Table B.26: Industrialization and income per capita, accounting for mines in 1837

\begin{tabular}{|c|c|c|c|c|c|c|c|c|}
\hline & $(1)$ & $(2)$ & $(3)$ & (4) & $(5)$ & $(6)$ & $(7)$ & $(8)$ \\
\hline & \multicolumn{2}{|c|}{ GDP per capita, 1860} & \multicolumn{2}{|c|}{ GDP per capita, 1901} & \multicolumn{2}{|c|}{ GDP per capita, 1930} & \multicolumn{2}{|c|}{ GDP per capita, 2001-2005 } \\
\hline $\begin{array}{l}\text { Horse Power of Steam Engines } \\
\text { Area Covered by Mines in Department }\end{array}$ & $\begin{array}{l}0.102^{* * *} \\
{[0.0366]}\end{array}$ & $\begin{array}{c}0.150^{* *} \\
{[0.0593]} \\
-0.0428^{* *} \\
{[0.0210]}\end{array}$ & $\begin{array}{c}0.231^{* * *} \\
{[0.0796]}\end{array}$ & $\begin{array}{c}0.304^{* *} \\
{[0.129]} \\
-0.0654 \\
{[0.0445]}\end{array}$ & $\begin{array}{c}0.0999^{* * *} \\
{[0.0244]}\end{array}$ & $\begin{array}{c}0.128^{* * *} * \\
{[0.0393]} \\
-0.0263^{*} \\
{[0.0153]}\end{array}$ & $\begin{array}{c}-0.0603^{* * *} \\
{[0.0221]}\end{array}$ & $\begin{array}{c}-0.0591^{* *} \\
{[0.0261]} \\
0.0029 \\
{[0.0090]}\end{array}$ \\
\hline $\begin{array}{l}\text { Geographic Characteristics } \\
\text { Institutional Characteristics } \\
\text { Pre-Industrial Development }\end{array}$ & $\begin{array}{l}\text { Yes } \\
\text { Yes } \\
\text { Yes }\end{array}$ & $\begin{array}{l}\text { Yes } \\
\text { Yes } \\
\text { Yes }\end{array}$ & $\begin{array}{l}\text { Yes } \\
\text { Yes } \\
\text { Yes }\end{array}$ & $\begin{array}{l}\text { Yes } \\
\text { Yes } \\
\text { Yes }\end{array}$ & $\begin{array}{l}\text { Yes } \\
\text { Yes } \\
\text { Yes }\end{array}$ & $\begin{array}{l}\text { Yes } \\
\text { Yes } \\
\text { Yes }\end{array}$ & $\begin{array}{l}\text { Yes } \\
\text { Yes } \\
\text { Yes }\end{array}$ & $\begin{array}{l}\text { Yes } \\
\text { Yes } \\
\text { Yes }\end{array}$ \\
\hline \multirow[t]{2}{*}{ Observations } & 87 & 87 & 85 & 85 & 87 & 87 & 89 & 89 \\
\hline & \multicolumn{8}{|c|}{ First stage: Instrumented variable - Log Horse Power of Steam Engines } \\
\hline Temperature Deviations & $\begin{array}{c}-0.0073^{* * *} * \\
{[0.0026]} \\
-4.350^{*} \\
{[2.246]}\end{array}$ & $\begin{array}{c}-0.0053^{* *} \\
{[0.0023]} \\
-3.023 \\
{[1.989]}\end{array}$ & $\begin{array}{c}-0.0073^{* * *} \\
{[0.0027]} \\
-3.986^{*} \\
{[2.337]}\end{array}$ & $\begin{array}{c}-0.0050^{* *} \\
{[0.0024]} \\
-2.851 \\
{[2.058]}\end{array}$ & $\begin{array}{c}-0.0075^{* * *} \\
{[0.0027]} \\
-4.152^{*} \\
{[2.313]}\end{array}$ & $\begin{array}{c}-0.0053^{* *} \\
{[0.0023]} \\
-3.051 \\
{[2.046]}\end{array}$ & $\begin{array}{c}-0.0075^{* * *} \\
{[0.0026]} \\
-4.254^{* *} \\
{[2.092]}\end{array}$ & $\begin{array}{c}-0.0052^{* *} \\
{[0.0023]} \\
-4.075^{* *} \\
{[2.024]}\end{array}$ \\
\hline $\begin{array}{l}\text { F-stat (1st stage) } \\
\text { J-stat (p-value) }\end{array}$ & $\begin{array}{c}12.963 \\
0.255 \\
\end{array}$ & $\begin{array}{l}9.479 \\
0.294 \\
\end{array}$ & $\begin{array}{c}12.134 \\
0.644 \\
\end{array}$ & $\begin{array}{l}8.363 \\
0.648 \\
\end{array}$ & $\begin{array}{c}12.708 \\
0.842 \\
\end{array}$ & $\begin{array}{l}9.366 \\
0.817 \\
\end{array}$ & $\begin{array}{c}13.644 \\
0.101 \\
\end{array}$ & $\begin{array}{c}11.507 \\
0.096 \\
\end{array}$ \\
\hline
\end{tabular}

Note: All regressions include a dummy variable for the three departments which had no steam engine in 1860-1865. Aerial distances are measured in kilometers. All the other explanatory variables, except the dummies, and the dependent variables are in logarithm. Geographic characteristics include the department's latitude, land suitability, average rainfall and temperature, share of carboniferous area, distance to Paris as well as dummies for the presence of rivers and tributaries, maritime and border departments. Institutional measures include dummies for Alsace-Lorraine and for Paris and its suburbs. Pre-industrial development characteristics include a measure of the urban population in 1700 . Robust standard errors are reported in brackets. *** indicates significance at the $1 \%$-level, ** at the $5 \%$-level, * at the $10 \%$-level. 
Table B.27: Industrialization and income per capita, accounting for market integration during the French Revolution

\begin{tabular}{|c|c|c|c|c|c|c|c|c|}
\hline & $\begin{array}{l}\text { (1) } \\
\text { IV }\end{array}$ & $\begin{array}{l}(2) \\
\text { IV }\end{array}$ & $\begin{array}{l}\text { (3) } \\
\text { IV }\end{array}$ & $\begin{array}{l}(4) \\
\text { IV }\end{array}$ & $\begin{array}{l}\text { (5) } \\
\text { IV }\end{array}$ & $\begin{array}{l}\text { (6) } \\
\text { IV }\end{array}$ & $\begin{array}{l}\text { (7) } \\
\text { IV }\end{array}$ & $\begin{array}{l}\text { (8) } \\
\text { IV }\end{array}$ \\
\hline & \multicolumn{2}{|c|}{ GDP per capita, 1860} & \multicolumn{2}{|c|}{ GDP per capita, 1901} & \multicolumn{2}{|c|}{ GDP per capita, 1930} & \multicolumn{2}{|c|}{ GDP per capita, 2001-2005 } \\
\hline $\begin{array}{l}\text { Horse Power of Steam Engines } \\
\text { Market Integration during the French Revolution }\end{array}$ & $\begin{array}{c}0.102^{* * *} \\
{[0.0366]}\end{array}$ & $\begin{array}{c}0.0949^{* *} \\
{[0.0373]} \\
-0.00324 \\
{[0.0544]}\end{array}$ & $\begin{array}{c}0.231^{* * * *} \\
{[0.0796]}\end{array}$ & $\begin{array}{c}0.233^{* * *} \\
{[0.0814]} \\
-0.230 * * \\
{[0.103]}\end{array}$ & $\begin{array}{c}0.0999^{* * *} \\
{[0.0244]}\end{array}$ & $\begin{array}{c}0.100^{* * *} \\
{[0.0260]} \\
-0.0417 \\
{[0.0357]}\end{array}$ & $\begin{array}{c}-0.0603^{* * *} \\
{[0.0221]}\end{array}$ & $\begin{array}{c}-0.0671^{* * *} \\
{[0.0242]} \\
0.109^{* * *} \\
{[0.0338]}\end{array}$ \\
\hline $\begin{array}{l}\text { Geographic Characteristics } \\
\text { Institutional Characteristics } \\
\text { Pre-Industrial Development }\end{array}$ & $\begin{array}{l}\text { Yes } \\
\text { Yes } \\
\text { Yes }\end{array}$ & $\begin{array}{l}\text { Yes } \\
\text { Yes } \\
\text { Yes }\end{array}$ & $\begin{array}{l}\text { Yes } \\
\text { Yes } \\
\text { Yes }\end{array}$ & $\begin{array}{l}\text { Yes } \\
\text { Yes } \\
\text { Yes }\end{array}$ & $\begin{array}{l}\text { Yes } \\
\text { Yes } \\
\text { Yes }\end{array}$ & $\begin{array}{l}\text { Yes } \\
\text { Yes } \\
\text { Yes }\end{array}$ & $\begin{array}{l}\text { Yes } \\
\text { Yes } \\
\text { Yes }\end{array}$ & $\begin{array}{l}\text { Yes } \\
\text { Yes } \\
\text { Yes }\end{array}$ \\
\hline \multirow[t]{2}{*}{ Observations } & 87 & 85 & 85 & 83 & 87 & 85 & 89 & 86 \\
\hline & \multicolumn{8}{|c|}{ First stage: Instrumented variable - Log Horse Power of Steam Engines } \\
\hline $\begin{array}{l}\text { Distance to Fresnes } \\
\text { Temperature Deviations }\end{array}$ & $\begin{array}{c}-0.0073^{* * *} \\
{[0.0026]} \\
-4.350^{*} \\
{[2.246]}\end{array}$ & $\begin{array}{c}-0.0063^{* *} \\
{[0.0029]} \\
-4.441^{* *} \\
{[1.983]}\end{array}$ & $\begin{array}{c}-0.0073^{* * *} \\
{[0.0027]} \\
-3.986^{*} \\
{[2.337]}\end{array}$ & $\begin{array}{c}-0.0062^{* *} \\
{[0.0029]} \\
-4.168^{* *} \\
{[2.024]}\end{array}$ & $\begin{array}{c}-0.0075^{* * *} * \\
{[0.0027]} \\
-4.152^{*} \\
{[2.313]}\end{array}$ & $\begin{array}{c}-0.0065^{* *} \\
{[0.0029]} \\
-4.315^{* *} \\
{[2.006]}\end{array}$ & $\begin{array}{c}-0.0075^{* * *} \\
{[0.0026]} \\
-4.254^{* *} \\
{[2.092]}\end{array}$ & $\begin{array}{c}-0.0065^{* *} \\
{[0.0029]} \\
-4.340^{* *} \\
{[2.006]}\end{array}$ \\
\hline $\begin{array}{l}\text { F-stat } \\
\text { J-stat (p-value) }\end{array}$ & $\begin{array}{c}12.963 \\
0.255\end{array}$ & $\begin{array}{c}11.069 \\
0.289\end{array}$ & $\begin{array}{c}12.134 \\
0.644 \\
\end{array}$ & $\begin{array}{c}10.227 \\
0.620\end{array}$ & $\begin{array}{c}12.708 \\
0.842\end{array}$ & $\begin{array}{c}10.821 \\
0.919\end{array}$ & $\begin{array}{c}13.644 \\
0.101\end{array}$ & $\begin{array}{c}10.962 \\
0.044 \\
\end{array}$ \\
\hline
\end{tabular}

Note: All regressions include a dummy variable for the three departments which had no steam engine in 1860-1865. Aerial distances are measured in kilometers. Other explanatory variables, except the dummies, and the dependent variables are in logarithm. Geographic characteristics include the department's latitude, land suitability, average rainfall and temperature, share of carboniferous area, distance to Paris as well as dummies for the presence of rivers and tributaries, maritime and border departments. Institutional measures include dummies for Alsace-Lorraine and for Paris and its suburbs. Pre-industrial development characteristics include a measure of the urban population in 1700 . Robust standard errors are reported in brackets. *** indicates significance at the $1 \%$-level, $* *$ at the $5 \%$-level, $*$ at the $10 \%$-level. 
Table B.28: Industrialization and income per capita, accounting for the railroad network in 1860

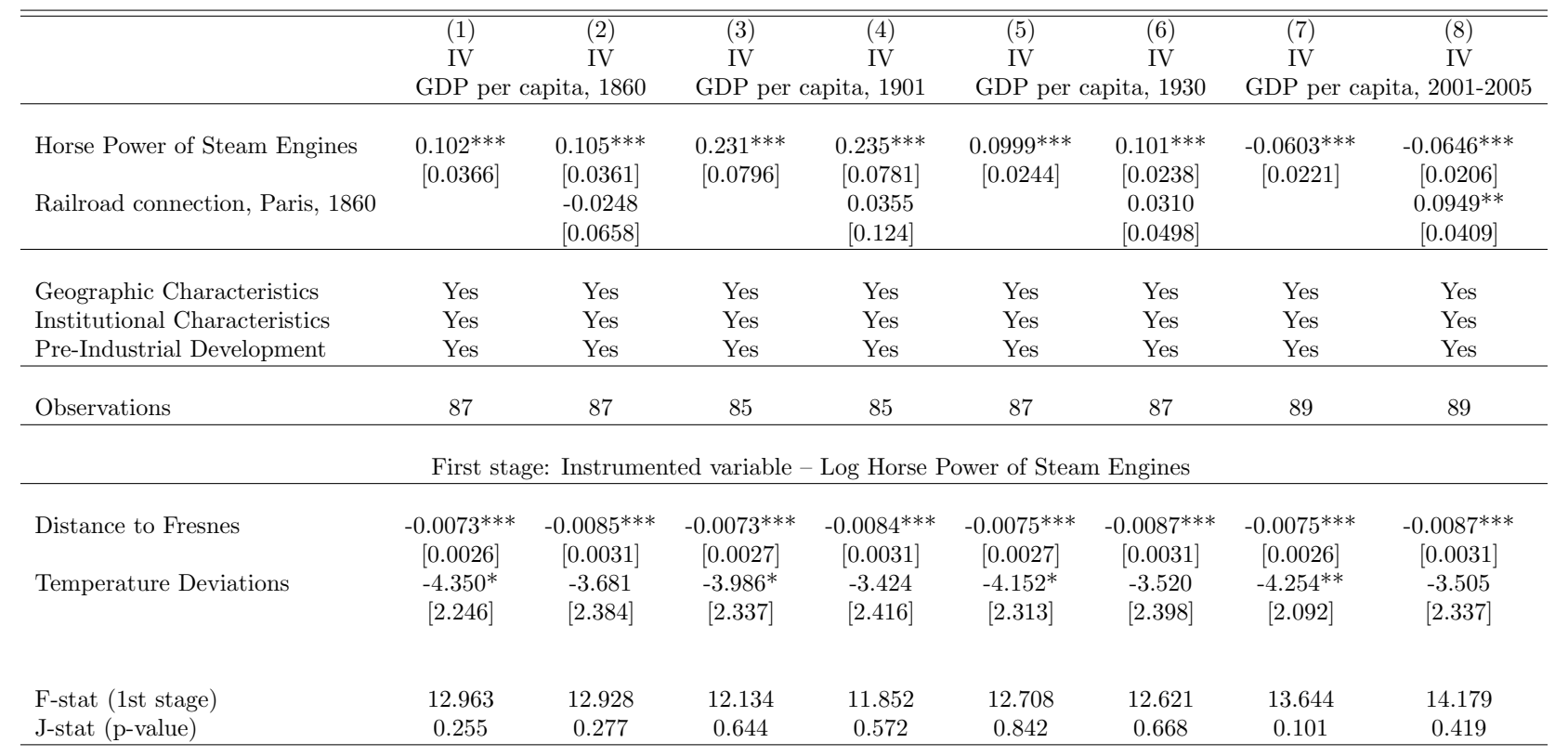

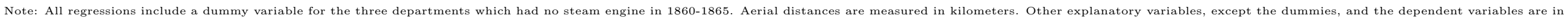

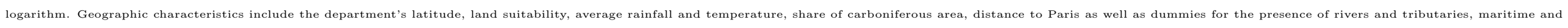

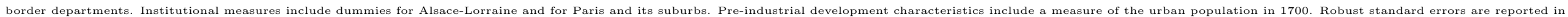
brackets. ${ }^{* * *}$ indicates significance at the $1 \%$-level, ${ }^{* *}$ at the $5 \%$-level, $*$ at the $10 \%$-level. 
Table B.29: Industrialization and income per capita, accounting for the concentration of the industrial sector in 1860-1865 by horse power

\begin{tabular}{|c|c|c|c|c|c|c|c|c|}
\hline & $\begin{array}{l}(1) \\
\text { IV }\end{array}$ & $\begin{array}{l}(2) \\
\text { IV }\end{array}$ & $\begin{array}{l}(3) \\
\text { IV }\end{array}$ & $\begin{array}{l}(4) \\
\text { IV }\end{array}$ & $\begin{array}{l}(5) \\
\text { IV }\end{array}$ & $\begin{array}{l}(6) \\
\text { IV }\end{array}$ & $\begin{array}{l}(7) \\
\text { IV }\end{array}$ & $\begin{array}{l}(8) \\
\text { IV }\end{array}$ \\
\hline & \multicolumn{2}{|c|}{ Log GDP per capita, 1860} & \multicolumn{2}{|c|}{ Log GDP per capita, 1901} & \multicolumn{2}{|c|}{ Log GDP per capita, 1930} & \multicolumn{2}{|c|}{ Log GDP per capita, 2001-2005 } \\
\hline $\begin{array}{l}\text { Log Horse Power of Steam Engines } \\
\text { Log Concentration Index (Horse Power by Sector) }\end{array}$ & $\begin{array}{c}0.102^{* * *} \\
{[0.0366]}\end{array}$ & $\begin{array}{c}0.0852^{* *} \\
{[0.0342]} \\
0.124 \\
{[0.114]}\end{array}$ & $\begin{array}{c}0.231 * * * \\
{[0.0796]}\end{array}$ & $\begin{array}{c}0.219^{* * *} \\
{[0.0762]} \\
0.292 \\
{[0.255]}\end{array}$ & $\begin{array}{c}0.0999 * * * \\
{[0.0244]}\end{array}$ & $\begin{array}{c}0.0951^{* * *} \\
{[0.0238]} \\
0.0866 \\
{[0.0937]}\end{array}$ & $\begin{array}{c}-0.0603^{* * *} \\
{[0.0221]}\end{array}$ & $\begin{array}{c}-0.0560^{* * *} \\
{[0.0211]} \\
-0.124 \\
{[0.0929]}\end{array}$ \\
\hline $\begin{array}{l}\text { Geographic Characteristics } \\
\text { Institutional Characteristics } \\
\text { Pre-Industrial Development }\end{array}$ & $\begin{array}{l}\text { Yes } \\
\text { Yes } \\
\text { Yes }\end{array}$ & $\begin{array}{l}\text { Yes } \\
\text { Yes } \\
\text { Yes }\end{array}$ & $\begin{array}{l}\text { Yes } \\
\text { Yes } \\
\text { Yes }\end{array}$ & $\begin{array}{l}\text { Yes } \\
\text { Yes } \\
\text { Yes }\end{array}$ & $\begin{array}{l}\text { Yes } \\
\text { Yes } \\
\text { Yes }\end{array}$ & $\begin{array}{l}\text { Yes } \\
\text { Yes } \\
\text { Yes }\end{array}$ & $\begin{array}{l}\text { Yes } \\
\text { Yes } \\
\text { Yes }\end{array}$ & $\begin{array}{l}\text { Yes } \\
\text { Yes } \\
\text { Yes }\end{array}$ \\
\hline \multirow[t]{2}{*}{ Observations } & 87 & 83 & 85 & 81 & 87 & 83 & 89 & 85 \\
\hline & \multicolumn{8}{|c|}{ First stage: Instrumented variable - Log Horse Power of Steam Engines } \\
\hline Temperature Deviations & $\begin{array}{c}-0.0073^{* * *} \\
{[0.0026]} \\
-4.350^{*} \\
{[2.246]}\end{array}$ & $\begin{array}{c}-0.0075^{* *} \\
{[0.0029]} \\
-4.696^{*} \\
{[2.404]}\end{array}$ & $\begin{array}{c}-0.0073^{* * *} \\
{[0.0027]} \\
-3.986^{*} \\
{[2.337]}\end{array}$ & $\begin{array}{c}-0.0078^{* *} \\
{[0.0030]} \\
-4.080 \\
{[2.543]}\end{array}$ & $\begin{array}{c}-0.0075 * * * \\
{[0.0027]} \\
-4.152^{*} \\
{[2.313]}\end{array}$ & $\begin{array}{c}-0.0079^{* *} \\
{[0.0030]} \\
-4.355^{*} \\
{[2.497]}\end{array}$ & $\begin{array}{c}-0.0075^{* * *} * \\
{[0.0026]} \\
-4.254^{* *} \\
{[2.092]}\end{array}$ & $\begin{array}{c}-0.0079^{* * *} \\
{[0.0029]} \\
-4.472^{* *} \\
{[2.204]}\end{array}$ \\
\hline $\begin{array}{l}\text { F-stat (1st stage) } \\
\text { J-stat (p-value) }\end{array}$ & $\begin{array}{c}12.963 \\
0.255\end{array}$ & $\begin{array}{c}12.927 \\
0.192\end{array}$ & $\begin{array}{c}12.134 \\
0.644\end{array}$ & $\begin{array}{c}12.117 \\
0.664\end{array}$ & $\begin{array}{c}12.708 \\
0.842\end{array}$ & $\begin{array}{c}12.613 \\
0.835\end{array}$ & $\begin{array}{c}13.644 \\
0.101\end{array}$ & $\begin{array}{c}13.413 \\
0.184\end{array}$ \\
\hline
\end{tabular}

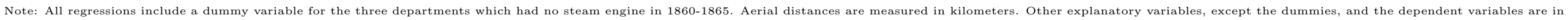

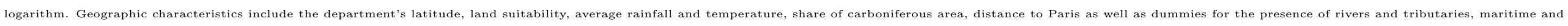

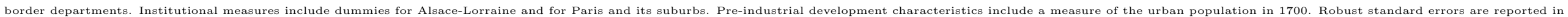
brackets. ${ }^{* * *}$ indicates significance at the $1 \%$-level, $* *$ at the $5 \%$-level, $*$ at the $10 \%$-level. 
Table B.30: Industrialization and income per capita, accounting for the concentration of the industrial sector in 1860-1865 by employment share

\begin{tabular}{|c|c|c|c|c|c|c|c|c|}
\hline & $\begin{array}{c}(1) \\
\text { IV } \\
\text { Log GDP p }\end{array}$ & $\begin{array}{c}(2) \\
\text { IV } \\
\text { capita, } 1860 \\
\end{array}$ & $\begin{array}{c}(3) \\
\text { IV } \\
\text { Log GDP p }\end{array}$ & $\begin{array}{c}(4) \\
\text { IV } \\
\text { capita, } 1901 \\
\end{array}$ & $\begin{array}{c}(5) \\
\text { IV } \\
\text { Log GDP p }\end{array}$ & $\begin{array}{c}(6) \\
\text { IV } \\
\text { capita, } 1930 \\
\end{array}$ & $\begin{array}{c}(7) \\
\text { IV } \\
\text { Log GDP p }\end{array}$ & $\begin{array}{c}(8) \\
\text { IV } \\
\text { apita, } 2001-2005 \\
\end{array}$ \\
\hline $\begin{array}{l}\text { Log Horse Power of Steam Engines } \\
\text { Log Concentration Index - Share of Employees in Industry }\end{array}$ & $\begin{array}{l}0.102 * * * \\
{[0.0366]}\end{array}$ & $\begin{array}{c}0.0957^{* *} \\
{[0.0372]} \\
0.184 \\
{[0.120]} \\
\end{array}$ & $\begin{array}{c}0.231 * * * \\
{[0.0796]}\end{array}$ & $\begin{array}{c}0.235^{* * *} \\
{[0.0798]} \\
-0.165 \\
{[0.230]} \\
\end{array}$ & $\begin{array}{c}0.0999 * * * \\
{[0.0244]}\end{array}$ & $\begin{array}{c}0.101 * * * \\
{[0.0243]} \\
-0.0479 \\
{[0.0827]}\end{array}$ & $\begin{array}{c}-0.0603^{* * *} \\
{[0.0221]}\end{array}$ & $\begin{array}{c}-0.0610^{* * *} \\
{[0.0235]} \\
0.0235 \\
{[0.0945]} \\
\end{array}$ \\
\hline $\begin{array}{l}\text { Geographic Characteristics } \\
\text { Institutional Characteristics } \\
\text { Pre-Industrial Development }\end{array}$ & $\begin{array}{l}\text { Yes } \\
\text { Yes } \\
\text { Yes }\end{array}$ & $\begin{array}{l}\text { Yes } \\
\text { Yes } \\
\text { Yes }\end{array}$ & $\begin{array}{l}\text { Yes } \\
\text { Yes } \\
\text { Yes }\end{array}$ & $\begin{array}{l}\text { Yes } \\
\text { Yes } \\
\text { Yes }\end{array}$ & $\begin{array}{l}\text { Yes } \\
\text { Yes } \\
\text { Yes }\end{array}$ & $\begin{array}{l}\text { Yes } \\
\text { Yes } \\
\text { Yes }\end{array}$ & $\begin{array}{l}\text { Yes } \\
\text { Yes } \\
\text { Yes }\end{array}$ & $\begin{array}{l}\text { Yes } \\
\text { Yes } \\
\text { Yes }\end{array}$ \\
\hline Observations & 87 & 87 & 85 & 85 & 87 & 87 & 89 & 89 \\
\hline & \multicolumn{8}{|c|}{ First stage: Instrumented variable - Log Horse Power of Steam Engines } \\
\hline $\begin{array}{l}\text { Distance to Fresnes } \\
\text { Temperature Deviations }\end{array}$ & $\begin{array}{c}-0.0073^{* * *} \\
{[0.0026]} \\
-4.350^{*} \\
{[2.246]}\end{array}$ & $\begin{array}{c}-0.0071^{* * *} \\
{[0.0026]} \\
-4.320^{*} \\
{[2.234]}\end{array}$ & $\begin{array}{c}-0.0073^{* * *} \\
{[0.0027]} \\
-3.986^{*} \\
{[2.337]}\end{array}$ & $\begin{array}{c}-0.0073^{* * *} \\
{[0.0027]} \\
-3.983^{*} \\
{[2.350]}\end{array}$ & $\begin{array}{c}-0.0075^{* * *} \\
{[0.0027]} \\
-4.152^{*} \\
{[2.313]}\end{array}$ & $\begin{array}{c}-0.0073^{* * *} \\
{[0.0027]} \\
-4.174^{*} \\
{[2.319]}\end{array}$ & $\begin{array}{c}-0.0075^{* * *} \\
{[0.0026]} \\
-4.254^{* *} \\
{[2.092]}\end{array}$ & $\begin{array}{c}-0.0073^{* * *} \\
{[0.0026]} \\
-4.223^{* *} \\
{[2.102]}\end{array}$ \\
\hline $\begin{array}{l}\text { F-stat (1st stage) } \\
\text { J-stat (p-value) }\end{array}$ & $\begin{array}{c}12.963 \\
0.255\end{array}$ & $\begin{array}{c}12.162 \\
0.260\end{array}$ & $\begin{array}{c}12.134 \\
0.644\end{array}$ & $\begin{array}{c}11.769 \\
0.611\end{array}$ & $\begin{array}{c}12.708 \\
0.842\end{array}$ & $\begin{array}{c}12.023 \\
0.816\end{array}$ & $\begin{array}{c}13.644 \\
0.101\end{array}$ & $\begin{array}{c}12.859 \\
0.097\end{array}$ \\
\hline
\end{tabular}

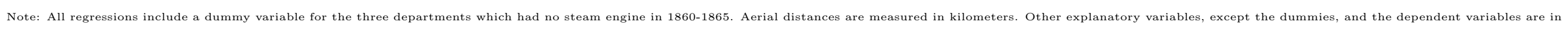

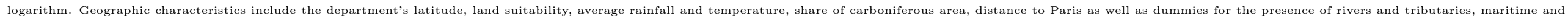

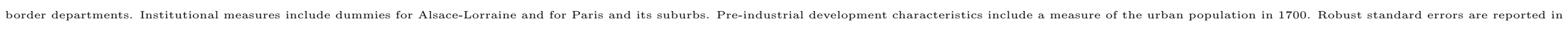
brackets. ${ }^{* * *}$ indicates significance at the $1 \%$-level, $* *$ at the $5 \%$-level, $*$ at the $10 \%$-level. 
Table B.31: Industrialization and income per capita, accounting for firm size in 1860-1865

\begin{tabular}{|c|c|c|c|c|c|c|c|c|}
\hline & $\begin{array}{l}1) \\
\text { IV }\end{array}$ & $\begin{array}{l}\text { (2) } \\
\text { IV }\end{array}$ & $\begin{array}{l}3) \\
\text { IV }\end{array}$ & $\begin{array}{l}\text { (4) } \\
\text { IV }\end{array}$ & $\begin{array}{l}\text { (5) } \\
\text { IV }\end{array}$ & $\begin{array}{l}\text { (6) } \\
\text { IV }\end{array}$ & $\begin{array}{l}\text { (7) } \\
\text { IV }\end{array}$ & $\begin{array}{l}\text { (8) } \\
\text { IV }\end{array}$ \\
\hline $\begin{array}{l}\text { Log Horse Power of Steam Engines } \\
\text { Log Number of Employees per Firm 1861-1865 }\end{array}$ & $\begin{array}{l}0.102^{* * *} \\
{[0.0366]}\end{array}$ & $\begin{array}{l}0.113^{* *} \\
{[0.0506]} \\
-0.0039 \\
{[0.0033]}\end{array}$ & $\begin{array}{c}0.231^{* * *} \\
{[0.0796]}\end{array}$ & $\begin{array}{c}0.277^{* * *} \\
{[0.104]} \\
-0.0161^{* * *} \\
{[0.0062]}\end{array}$ & $\begin{array}{c}0.0999^{* * *} \\
{[0.0244]}\end{array}$ & $\begin{array}{c}0.110^{* * *} \\
{[0.0339]} \\
-0.0030 \\
{[0.0023]}\end{array}$ & $\begin{array}{c}-0.0603^{* * *} \\
{[0.0221]}\end{array}$ & $\begin{array}{c}-0.0628^{* *} \\
{[0.0280]} \\
0.0034 \\
{[0.0024]}\end{array}$ \\
\hline $\begin{array}{l}\text { Geographic Characteristics } \\
\text { Institutional Characteristics } \\
\text { Pre-Industrial Development } \\
\end{array}$ & $\begin{array}{l}\text { Yes } \\
\text { Yes } \\
\text { Yes }\end{array}$ & $\begin{array}{l}\text { Yes } \\
\text { Yes } \\
\text { Yes }\end{array}$ & $\begin{array}{l}\text { Yes } \\
\text { Yes } \\
\text { Yes }\end{array}$ & $\begin{array}{l}\text { Yes } \\
\text { Yes } \\
\text { Yes }\end{array}$ & $\begin{array}{l}\text { Yes } \\
\text { Yes } \\
\text { Yes }\end{array}$ & $\begin{array}{l}\text { Yes } \\
\text { Yes } \\
\text { Yes }\end{array}$ & $\begin{array}{l}\text { Yes } \\
\text { Yes } \\
\text { Yes }\end{array}$ & $\begin{array}{l}\text { Yes } \\
\text { Yes } \\
\text { Yes }\end{array}$ \\
\hline Observations & 87 & 87 & 85 & 85 & 87 & 87 & 89 & 89 \\
\hline & \multicolumn{8}{|c|}{ First stage: Instrumented variable - Log Horse Power of Steam Engines } \\
\hline $\begin{array}{l}\text { Distance to Fresnes } \\
\text { Temperature Deviations }\end{array}$ & $\begin{array}{c}-0.0073^{* * *} \\
{[0.0026]} \\
-4.350^{*} \\
{[2.246]}\end{array}$ & $\begin{array}{c}-0.0040 \\
{[0.0027]} \\
-4.173^{* *} \\
{[1.746]}\end{array}$ & $\begin{array}{c}-0.0073^{* * *} \\
{[0.0027]} \\
-3.986 * \\
{[2.337]}\end{array}$ & $\begin{array}{c}-0.0037 \\
{[0.0029]} \\
-4.401 * * \\
{[1.842]}\end{array}$ & $\begin{array}{c}-0.0075 * * * \\
{[0.0027]} \\
-4.152^{*} \\
{[2.313]}\end{array}$ & $\begin{array}{c}-0.0037 \\
{[0.0029]} \\
-4.410^{* *} \\
{[1.839]}\end{array}$ & $\begin{array}{c}-0.0075^{* * *} \\
{[0.0026]} \\
-4.254^{* *} \\
{[2.092]}\end{array}$ & $\begin{array}{c}-0.0037 \\
{[0.0028]} \\
-4.724^{* * *} \\
{[1.690]}\end{array}$ \\
\hline $\begin{array}{l}\text { F-stat (1st stage) } \\
\text { J-stat (p-value) }\end{array}$ & $\begin{array}{c}12.963 \\
0.255\end{array}$ & $\begin{array}{l}7.375 \\
0.158\end{array}$ & $\begin{array}{c}12.134 \\
0.644\end{array}$ & $\begin{array}{l}7.394 \\
0.241\end{array}$ & $\begin{array}{c}12.708 \\
0.842\end{array}$ & $\begin{array}{l}7.320 \\
0.619\end{array}$ & $\begin{array}{c}13.644 \\
0.101\end{array}$ & $\begin{array}{l}9.420 \\
0.028\end{array}$ \\
\hline
\end{tabular}

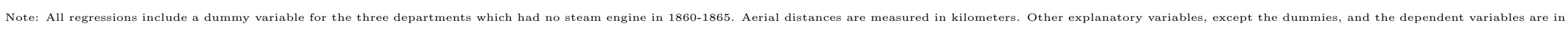

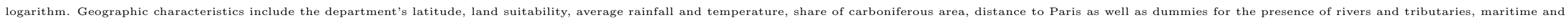

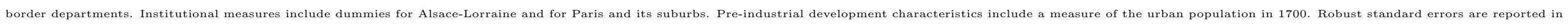
brackets. ${ }^{* * *}$ indicates significance at the $1 \%$-level, ${ }^{* *}$ at the $5 \%$-level, ${ }^{*}$ at the $10 \%$-level. 


\section{Appendix C. Industrialization and the Evolution of Sectoral Employment, 1861-2010}

Table C.1: Industrialization and the share of workforce in industry, 1861, 1901 and 1930

\begin{tabular}{|c|c|c|c|c|c|c|c|c|c|}
\hline & $\begin{array}{c}\text { (1) } \\
\text { OLS } \\
\text { Log Share } \\
\end{array}$ & $\begin{array}{c}\text { OLS } \\
\text { OLS } \\
\text { of Workforce } \\
\end{array}$ & $\begin{array}{c}(3) \\
\text { IV } \\
\text { Industry, } 1861 \\
\end{array}$ & $\begin{array}{c}(4) \\
\text { OLS } \\
\text { Log Share } \\
\end{array}$ & $\begin{array}{c}\text { OLS } \\
\text { OLS } \\
\text { of Workforce }\end{array}$ & $\begin{array}{c}(6) \\
\text { IV } \\
\text { Industry, } 1901 \\
\end{array}$ & $\begin{array}{c}\text { (7) } \\
\text { OLS } \\
\text { Log Share } \\
\end{array}$ & $\begin{array}{c}\text { OLS } \\
\text { OLS } \\
\text { of Workforce }\end{array}$ & $\begin{array}{c}(9) \\
\text { IV } \\
\text { Industry, } 1930 \\
\end{array}$ \\
\hline Log Horse Power of Steam Engines & $\begin{array}{l}0.0433^{* * *} * \\
{[0.00635]}\end{array}$ & $\begin{array}{l}0.0246^{* * *} \\
{[0.00557]}\end{array}$ & $\begin{array}{c}0.0501 * * * \\
{[0.0140]}\end{array}$ & $\begin{array}{l}0.0424^{* * *} \\
{[0.00611]}\end{array}$ & $\begin{array}{c}0.0337^{* * *} \\
{[0.00700]} \\
\end{array}$ & $\begin{array}{c}0.0641 * * * \\
{[0.0153]}\end{array}$ & $\begin{array}{l}0.0524^{* * *} \\
{[0.00776]}\end{array}$ & $\begin{array}{c}0.0392^{* * *} * \\
{[0.00794]} \\
\end{array}$ & $\begin{array}{c}0.0866^{* * *} * \\
{[0.0202]} \\
\end{array}$ \\
\hline $\begin{array}{l}\text { Geographic Characteristics } \\
\text { Institutional Characteristics } \\
\text { Pre-Industrial Development }\end{array}$ & $\begin{array}{l}\text { No } \\
\text { No } \\
\text { No }\end{array}$ & $\begin{array}{l}\text { Yes } \\
\text { Yes } \\
\text { Yes }\end{array}$ & $\begin{array}{l}\text { Yes } \\
\text { Yes } \\
\text { Yes }\end{array}$ & $\begin{array}{l}\text { No } \\
\text { No } \\
\text { No }\end{array}$ & $\begin{array}{l}\text { Yes } \\
\text { Yes } \\
\text { Yes }\end{array}$ & $\begin{array}{l}\text { Yes } \\
\text { Yes } \\
\text { Yes }\end{array}$ & $\begin{array}{l}\text { No } \\
\text { No } \\
\text { No }\end{array}$ & $\begin{array}{l}\text { Yes } \\
\text { Yes } \\
\text { Yes }\end{array}$ & $\begin{array}{l}\text { Yes } \\
\text { Yes } \\
\text { Yes }\end{array}$ \\
\hline $\begin{array}{l}\text { Adjusted R2 } \\
\text { Observations }\end{array}$ & $\begin{array}{c}0.460 \\
89\end{array}$ & $\begin{array}{c}0.630 \\
89\end{array}$ & 89 & $\begin{array}{c}0.528 \\
87\end{array}$ & $\begin{array}{c}0.588 \\
87\end{array}$ & 87 & $\begin{array}{c}0.501 \\
89\end{array}$ & $\begin{array}{c}0.678 \\
89\end{array}$ & 89 \\
\hline \multicolumn{10}{|c|}{ First stage: Instrumented variable - Log Horse Power of Steam Engines } \\
\hline Temperature Deviations & & & $\begin{array}{c}-0.0073^{* * *} \\
{[0.0026]} \\
-4.484^{* *} \\
{[1.995]}\end{array}$ & & & $\begin{array}{c}-0.0066^{* * *} \\
{[0.0026]} \\
-4.569^{* *} \\
{[2.111]}\end{array}$ & & & $\begin{array}{c}-0.0075^{* * *} \\
{[0.0026]} \\
-4.254^{* *} \\
{[2.092]}\end{array}$ \\
\hline $\begin{array}{l}\text { F-stat (1st stage) } \\
\text { J-stat (p-value) }\end{array}$ & & & $\begin{array}{c}14.340 \\
0.122\end{array}$ & & & $\begin{array}{c}13.274 \\
0.009\end{array}$ & & & $\begin{array}{c}13.644 \\
0.169\end{array}$ \\
\hline
\end{tabular}

Note: The dependent variables and the explanatory variables except the dummies are in logarithm. All regressions include a dummy variable for the three departments which had no steam engine in $1860-1865$. Aerial distances are measured in kilometers. Geographic characteristics include the department's latitude, land suitability, average rainfall and temperature, share of carboniferous area, distance to Paris as well as dummies for the presence of rivers and tributaries, maritime and border departments. Institutional measures include dummies for Alsace-Lorraine and for Paris and its suburbs. Pre-industrial development characteristics include a measure of the urban population in 1700 . Robust standard errors are reported in brackets. *** indicates significance at the $1 \%$-level, ** at the $5 \%$-level, $*$ at the $10 \%$-level 
Table C.2: Industrialization and the share of workforce in industry, 1968-2010

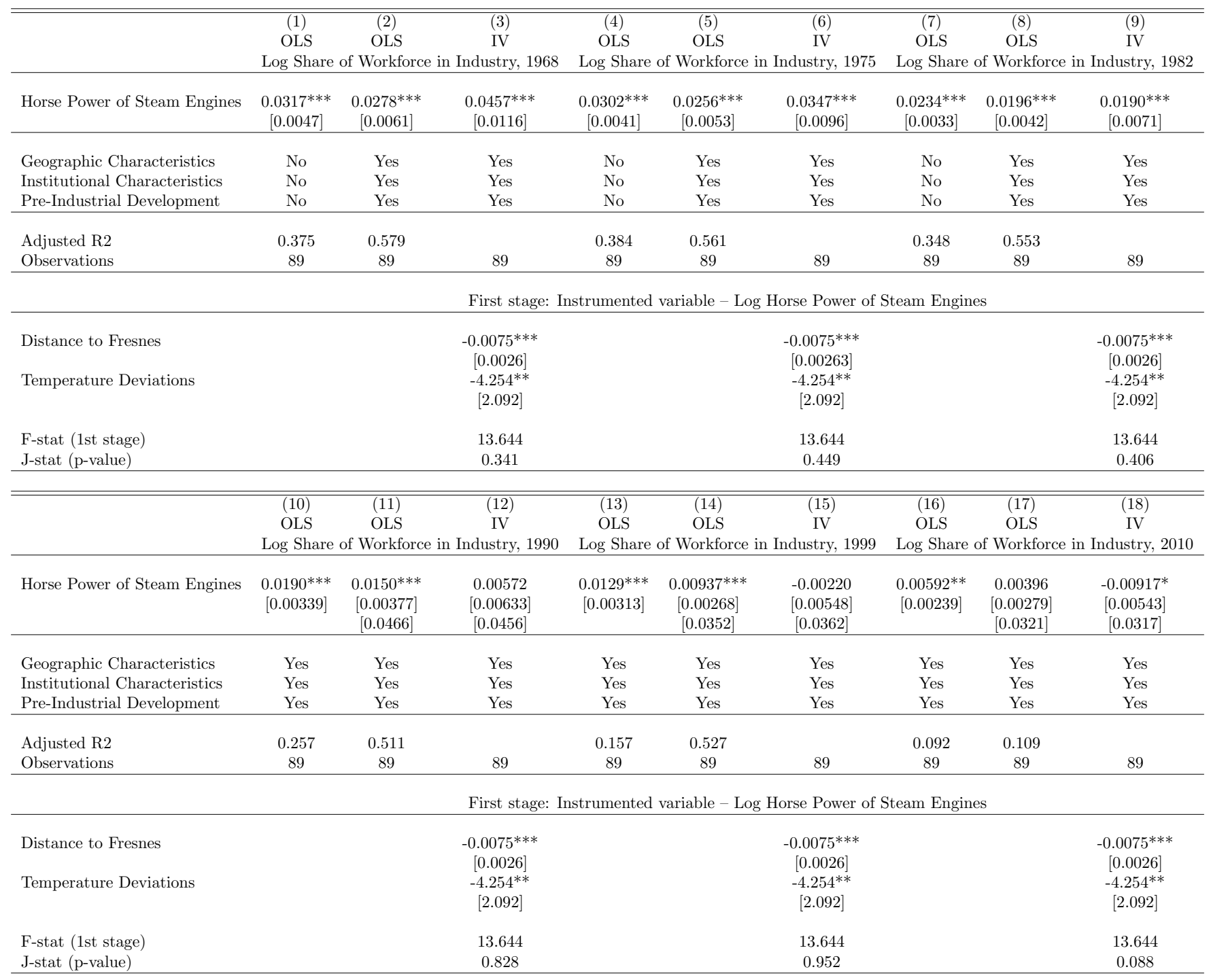

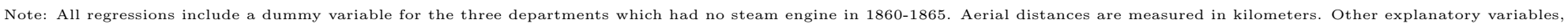

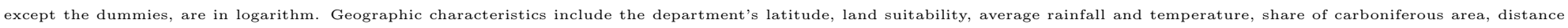

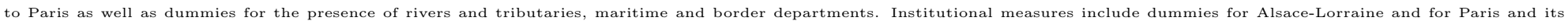

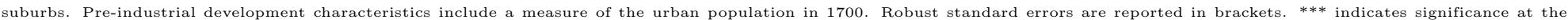
$1 \%$-level, ** at the $5 \%$-level, * at the $10 \%$-level. 
Table C.3: Industrialization and the share of workforce in services, 1861, $1901 \& 1930$

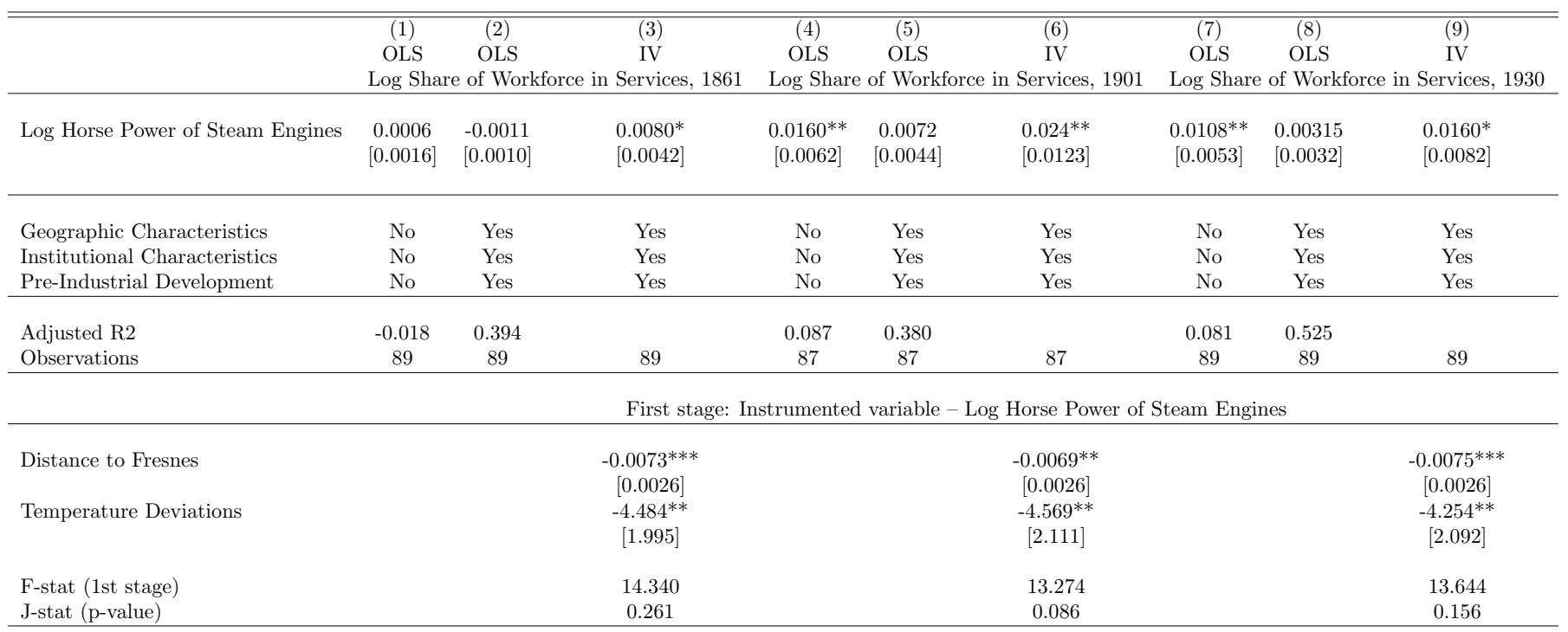

Note: All regressions include a dummy variable for the three departments which had no steam engine in 1860-1865. Aerial distances are measured in kilometers. Other explanatory variables, except the dummies, are in logarithm. Geographic characteristics include the department's latitude, land suitability, average rainfall and temperature, share of carboniferous area, distance to Paris as well as dummies for the presence of rivers and tributaries, maritime and border departments. Institutional measures include dummies for Alsace-Lorraine and for Paris and its suburbs. Pre-industrial development characteristics include a measure of the urban population in 1700 . Robust standard errors are reported in brackets. ${ }^{* * *}$ indicates significance at the $1 \%$-level, ${ }^{* *}$ at the $5 \%$-level, $*$ at the $10 \%$-level. 
Table C.4: Industrialization and the share of workforce in services, 1968-2010

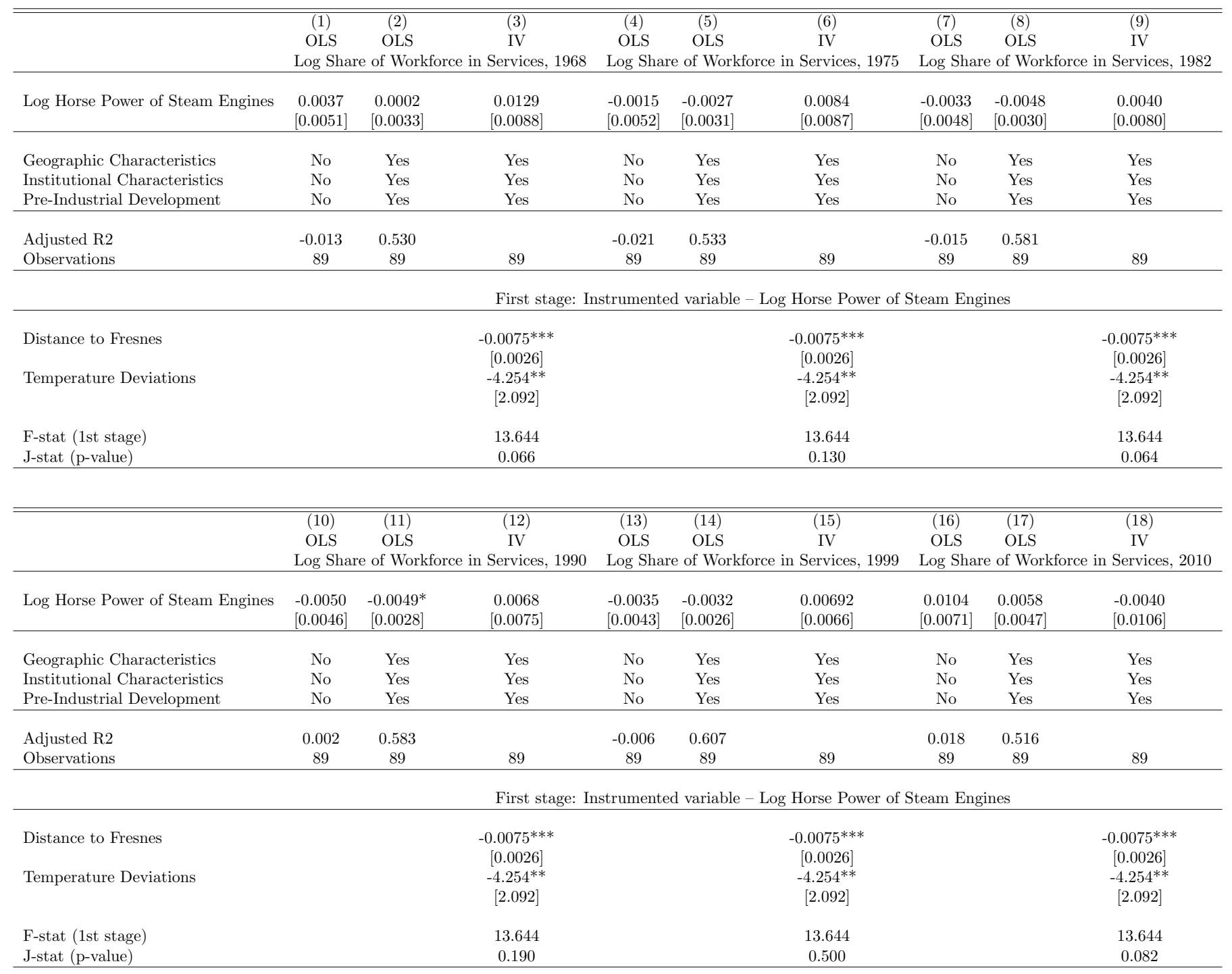

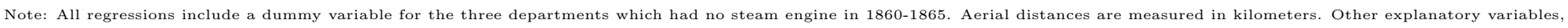

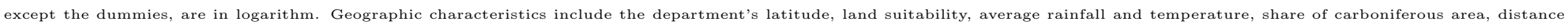

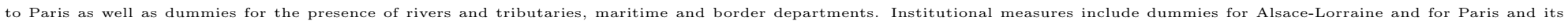

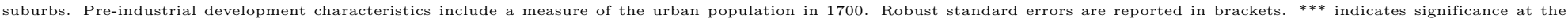
$1 \%$-level, ** at the $5 \%$-level, * at the $10 \%$-level. 
Table C.5: Industrialization and the share of executives in the workforce (age 25-54), 1968-2010

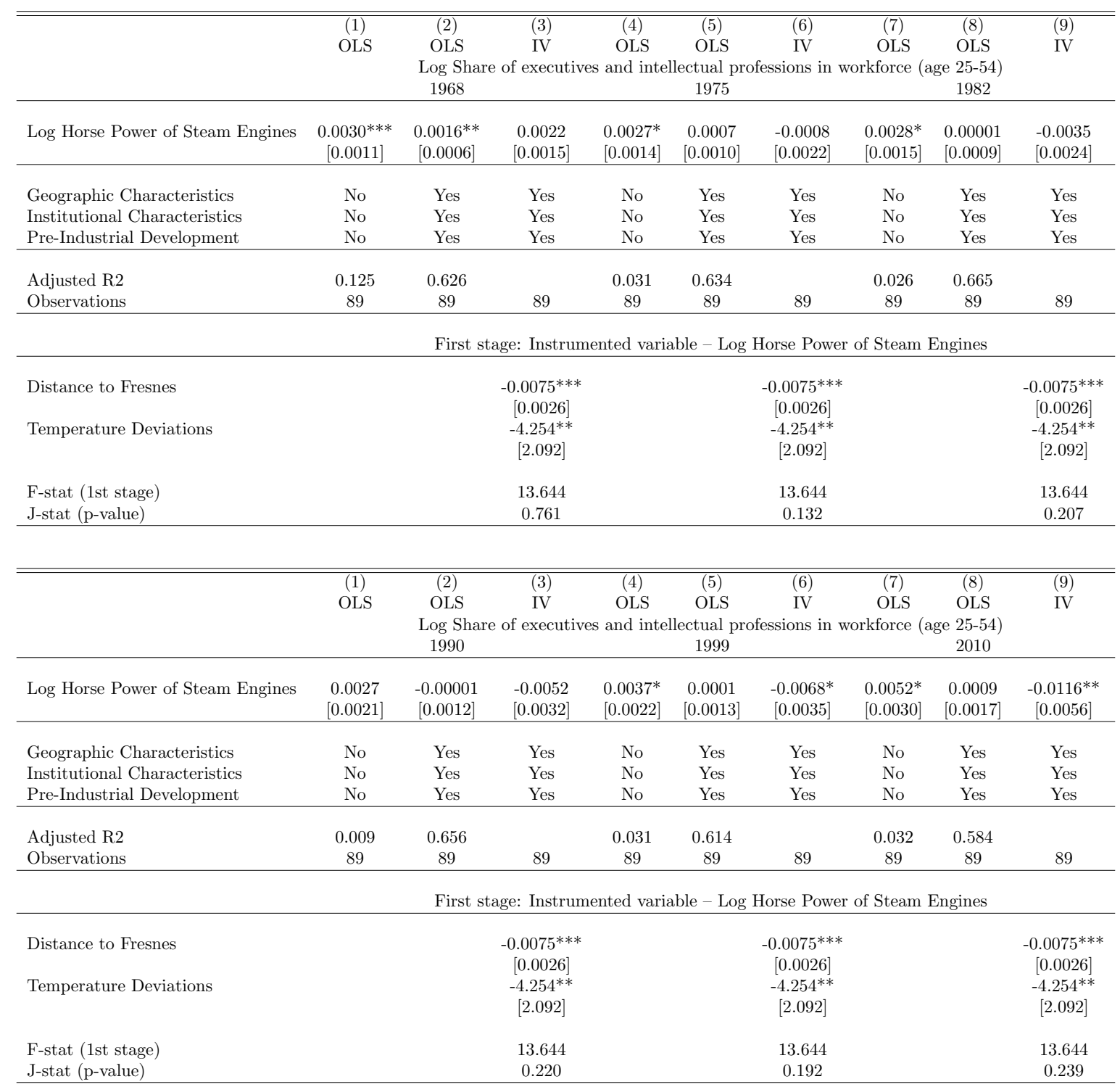

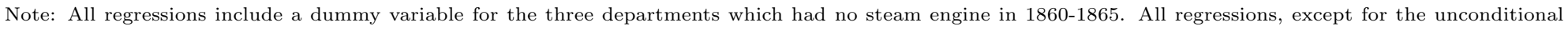

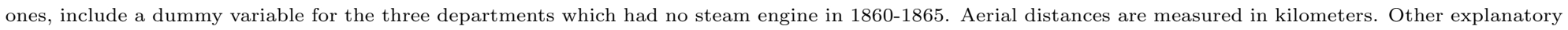

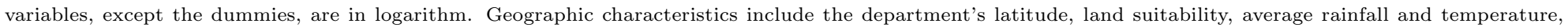

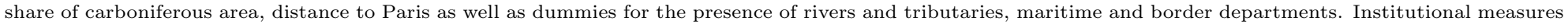

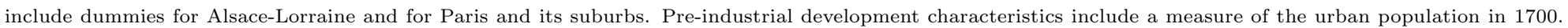

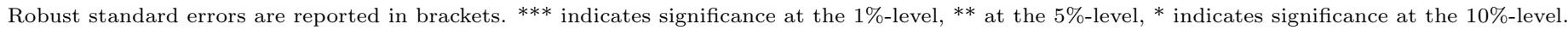


Table C.6: Industrialization and share of intermediary professionals in the workforce (age 25-54), 1968-2010

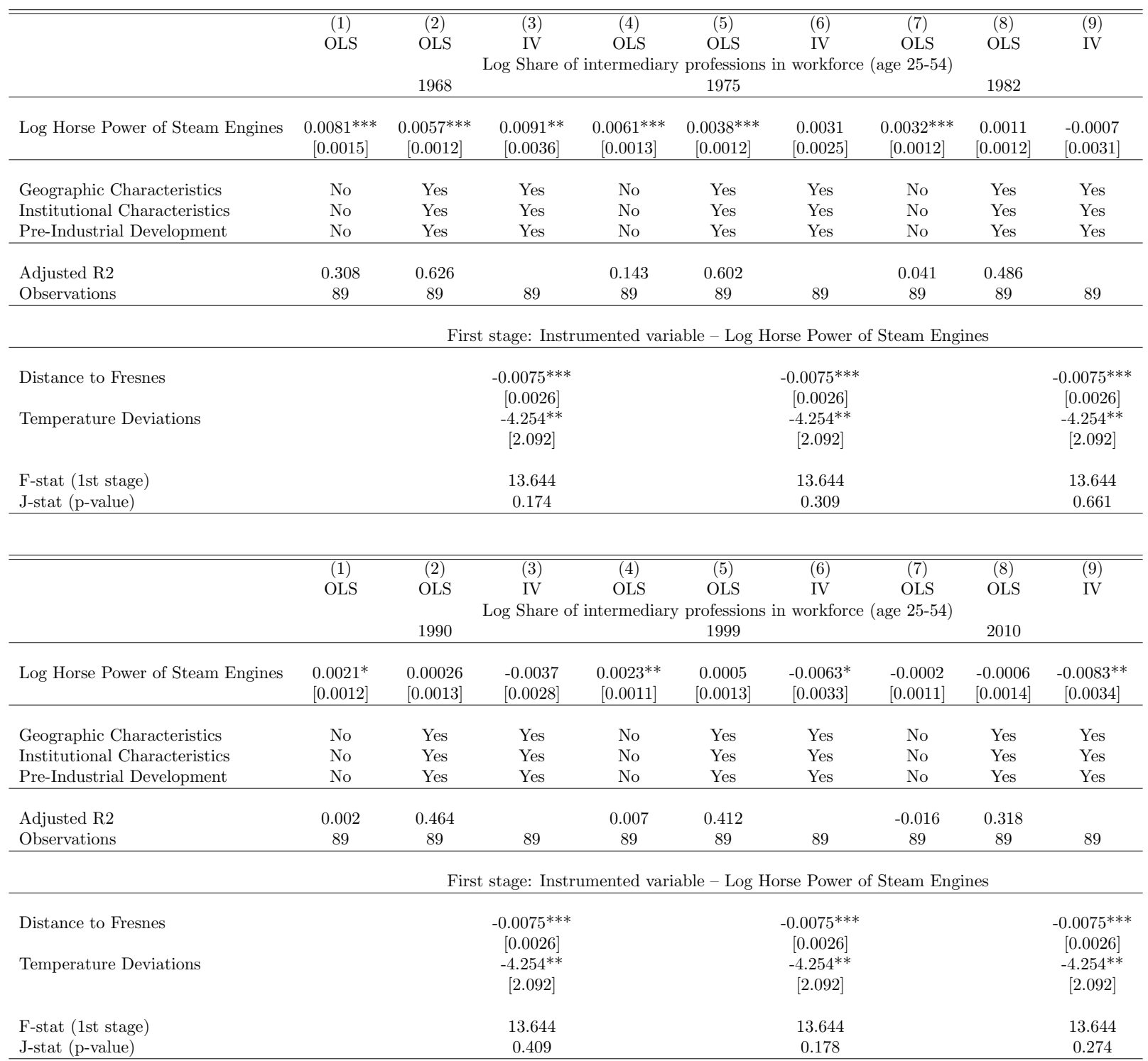

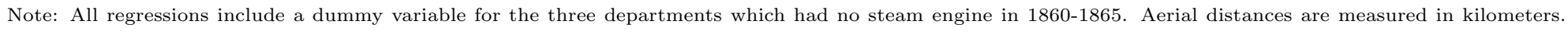

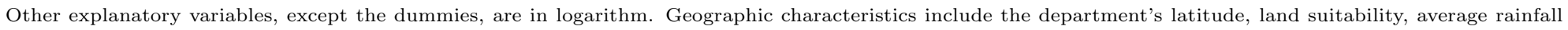

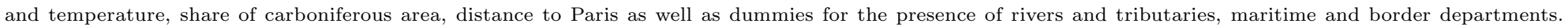

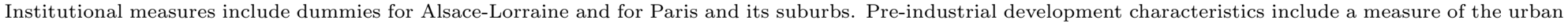

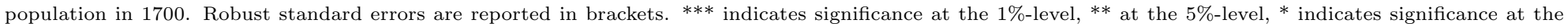
$10 \%$-level. 
Table C.7: Industrialization and the share of employees in the workforce (age 25-54), 1968-2010

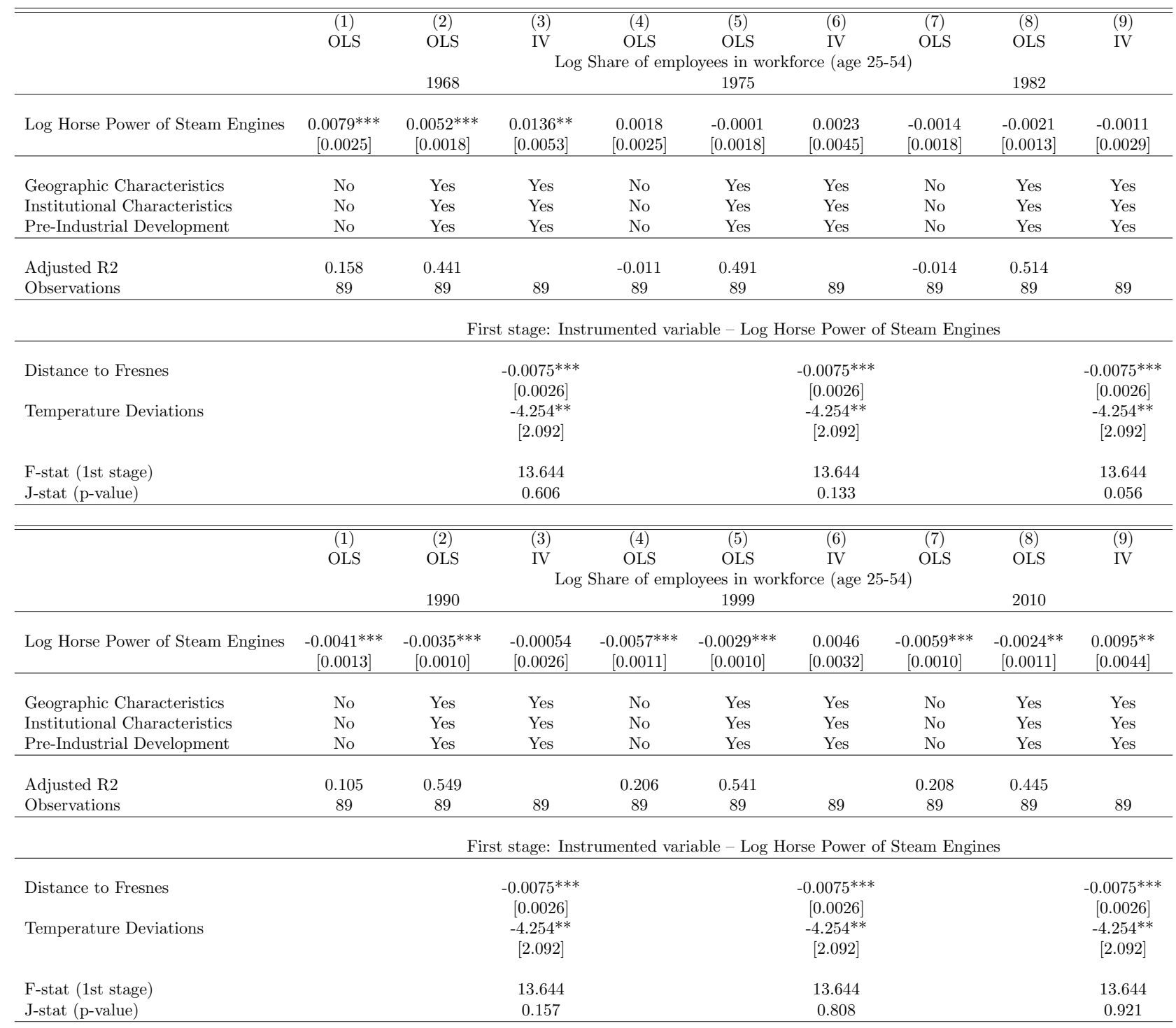

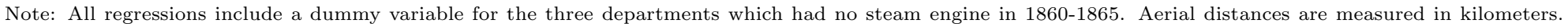

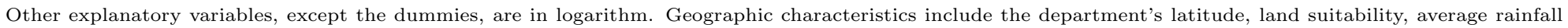

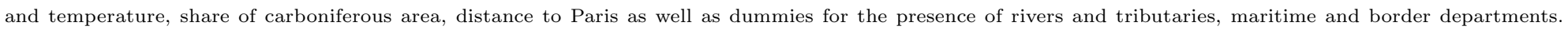

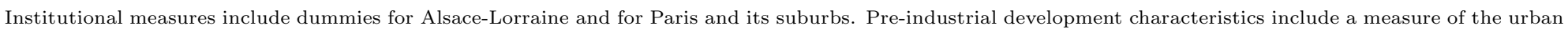

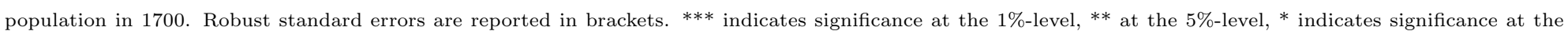
$10 \%$-level. 


\section{Appendix D. Industrialization and Education: Additional results}

Table D.1: Industrialization and female school enrollment in 2010

\begin{tabular}{|c|c|c|c|c|c|c|}
\hline & \multicolumn{3}{|c|}{$\begin{array}{c}\text { Log School Enrollment of Women } \\
\text { Age 15-17 in } 2010\end{array}$} & \multicolumn{3}{|c|}{$\begin{array}{l}\text { Log School Enrollment of Women } \\
\text { Age 18-24 in } 2010\end{array}$} \\
\hline Log Horse Power of Steam Engines & $\begin{array}{l}-0.0141 \\
{[0.0718]}\end{array}$ & $\begin{array}{l}-0.0321 \\
{[0.0679]}\end{array}$ & $\begin{array}{c}-0.769^{* * *} \\
{[0.224]}\end{array}$ & $\begin{array}{c}0.614 \\
{[0.447]}\end{array}$ & $\begin{array}{l}-0.552 \\
{[0.603]}\end{array}$ & $\begin{array}{c}-3.319^{* *} \\
{[1.311]}\end{array}$ \\
\hline $\begin{array}{l}\text { Geographic Characteristics } \\
\text { Institutional Characteristics } \\
\text { Pre-Industrial Development }\end{array}$ & $\begin{array}{l}\text { No } \\
\text { No } \\
\text { No }\end{array}$ & $\begin{array}{l}\text { Yes } \\
\text { Yes } \\
\text { Yes }\end{array}$ & $\begin{array}{l}\text { Yes } \\
\text { Yes } \\
\text { Yes }\end{array}$ & $\begin{array}{l}\text { No } \\
\text { No } \\
\text { No }\end{array}$ & $\begin{array}{l}\text { Yes } \\
\text { Yes } \\
\text { Yes }\end{array}$ & $\begin{array}{l}\text { Yes } \\
\text { Yes } \\
\text { Yes }\end{array}$ \\
\hline $\begin{array}{l}\text { Adjusted R2 } \\
\text { Observations }\end{array}$ & $\begin{array}{c}-0.005 \\
89\end{array}$ & $\begin{array}{c}0.195 \\
89\end{array}$ & 89 & $\begin{array}{c}0.021 \\
89\end{array}$ & $\begin{array}{c}0.441 \\
89\end{array}$ & 89 \\
\hline
\end{tabular}

First stage: the instrumented variable is Log Horse Power of Steam Engines

\begin{tabular}{lcc} 
Distance to Fresnes & $-0.0075^{* * *}$ & $-0.0075^{* * *}$ \\
& {$[0.0026]$} & {$[0.0026]$} \\
Temperature Deviations & $-4.254^{* *}$ & $-4.254^{* *}$ \\
& {$[2.092]$} & {$[2.092]$} \\
F-stat (1st stage) & & 13.644 \\
J-stat (p-value) & 13.644 & 0.450 \\
\hline
\end{tabular}

Note: All regressions include a dummy variable for the three departments which had no steam engine in 1860-1865. Aerial distances are measured in kilometers. Other explanatory variables, except the dummies, are in logarithm. Geographic characteristics include the department's latitude, land suitability, average rainfall and temperature, share of carboniferous area, distance to Paris as well as dummies for the presence of rivers and tributaries, maritime and border departments. Institutional measures include dummies for Alsace-Lorraine and for Paris and its suburbs. Pre-industrial development characteristics include a measure of the urban population in 1700 . Robust standard errors are reported in brackets. *** indicates significance at the $1 \%$-level, ** at the $5 \%$-level, * at the $10 \%$-level. 
As reported in Column (3) of Table D.2, the horse power of steam engines in industrial production in 1860-1865 had initially a positive and highly significant effect on the literacy of the French army conscripts in the years 1874-1883. However, due to the legislation of the 1881-1882 education laws, which made primarily schooling compulsory and free until the age of 13 , the effect was quantitatively smaller but still statistically significant in the years 1894-1903 (Column (6)). Eventually, this effect had vanished in the years 1910-1912 (Column (9)).

Table D.2: Industrialization and Literacy of conscripts, 1874-1883, 1894-1903 \& 1910-1912

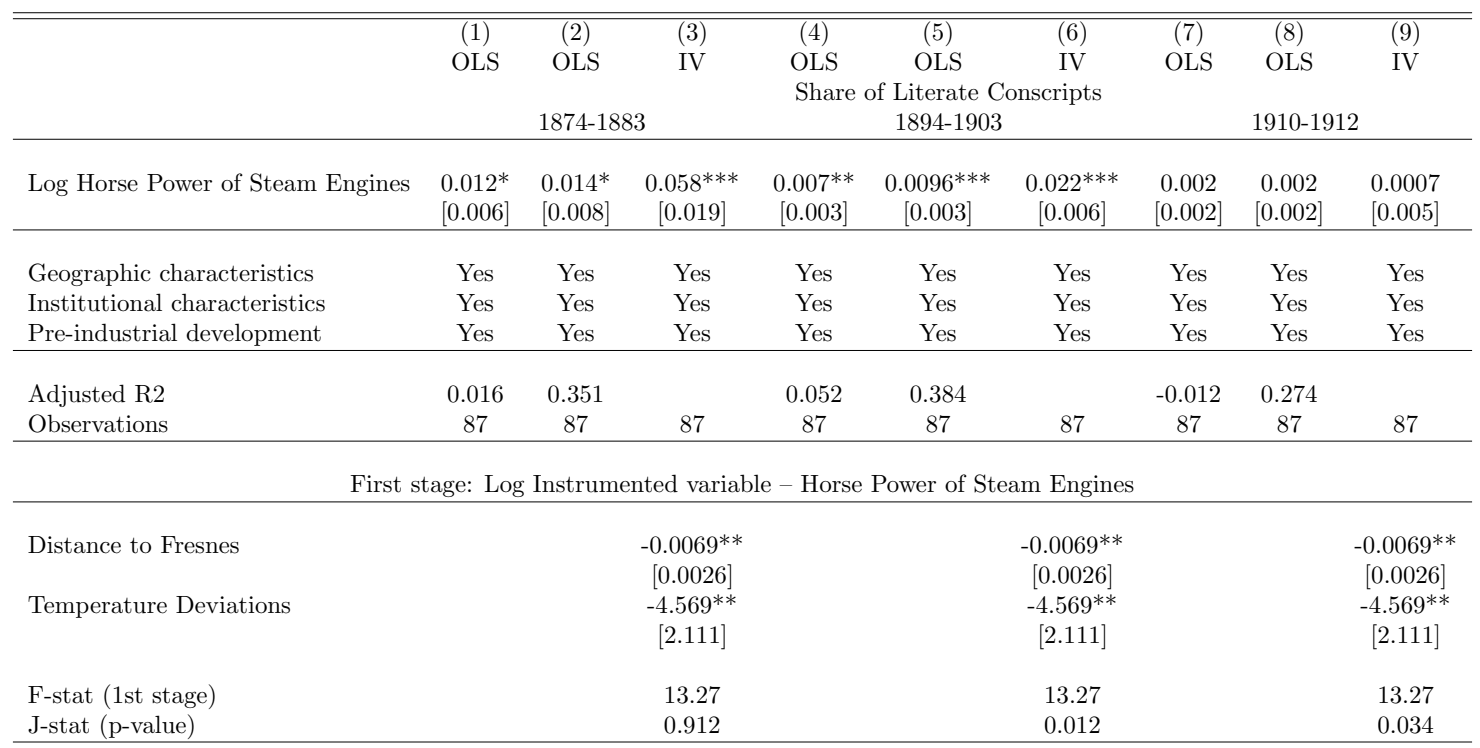

Note: This table presents OLS and IV regressions relating the horse power of steam engines in 1860-1865 to the share of literate conscripts over the $1874-$ 1883, 1894-1903 and 1910-1912 periods. All regressions include a dummy variable for the three departments which had no steam engine in 1860-1865. Aerial distances are measured in kilometers. Other explanatory variables, except the dummies, are in logarithm. Geographic characteristics include the department's latitude, land suitability, average rainfall and temperature, share of carboniferous area, distance to Paris as well as dummies for the presence of rivers and tributaries, maritime and border departments. Institutional measures include dummies for Alsace-Lorraine and for Paris and its suburbs. Pre-industrial development characteristics include a measure of the urban population in 1700 . Heteroskedasticity-robust standard errors are reported in brackets. *** indicates significance at the $1 \%$-level, $* *$ at the $5 \%$-level, $*$ at the $10 \%$-level. 
Table D.3: The long-run effects of industrialization on human capital: women age 25 and above with a post-secondary degree, 1968-2010

\begin{tabular}{|c|c|c|c|c|c|c|}
\hline & $\begin{array}{l}\text { (1) } \\
\text { IV }\end{array}$ & $\begin{array}{l}(2) \\
\text { IV }\end{array}$ & $\begin{array}{l}\text { (3) } \\
\text { IV }\end{array}$ & $\begin{array}{l}\text { (4) } \\
\text { IV }\end{array}$ & $\begin{array}{l}\text { (5) } \\
\text { IV }\end{array}$ & $\begin{array}{l}\text { (6) } \\
\text { IV }\end{array}$ \\
\hline & \multicolumn{6}{|c|}{ Log Post-Secondary Degree (Female 25+) } \\
\hline & 1968 & 1975 & 1982 & 1990 & 1999 & 2010 \\
\hline Log Horse Power of Steam Engines & $\begin{array}{l}-0.0525 \\
{[0.0466]}\end{array}$ & $\begin{array}{c}-0.0679^{*} \\
{[0.0371]}\end{array}$ & $\begin{array}{c}-0.0752^{* *} \\
{[0.0339]}\end{array}$ & $\begin{array}{c}-0.0793^{* *} \\
{[0.0369]}\end{array}$ & $\begin{array}{c}-0.0708^{* *} \\
{[0.0327]}\end{array}$ & $\begin{array}{c}-0.0758^{* * *} \\
{[0.0288]}\end{array}$ \\
\hline Geographic characteristics & Yes & Yes & Yes & Yes & Yes & Yes \\
\hline Institutional characteristics & Yes & Yes & Yes & Yes & Yes & Yes \\
\hline Pre-industrial development & Yes & Yes & Yes & Yes & Yes & Yes \\
\hline \multirow[t]{2}{*}{ Observations } & 89 & 89 & 89 & 89 & 89 & 89 \\
\hline & \multicolumn{6}{|c|}{ First stage: Instrumented Variable - Log Horse Power of Steam Engines } \\
\hline Distance to Fresnes & $\begin{array}{c}-0.0064^{* *} \\
{[0.0025]}\end{array}$ & $\begin{array}{c}-0.0064^{* *} \\
{[0.0025]}\end{array}$ & $\begin{array}{c}-0.0064^{* *} \\
{[0.0025]}\end{array}$ & $\begin{array}{c}-0.0064^{* *} \\
{[0.0025]}\end{array}$ & $\begin{array}{c}-0.0064^{* *} \\
{[0.0025]}\end{array}$ & $\begin{array}{c}-0.0064^{* *} \\
{[0.0025]}\end{array}$ \\
\hline Temperature Deviations & $\begin{array}{c}-4.836^{* *} \\
{[2.306]}\end{array}$ & $\begin{array}{c}-4.836^{* *} \\
{[2.306]}\end{array}$ & $\begin{array}{c}-4.836^{* *} \\
{[2.306]}\end{array}$ & $\begin{array}{c}-4.836^{* *} \\
{[2.306]}\end{array}$ & $\begin{array}{c}-4.836^{* *} \\
{[2.306]}\end{array}$ & $\begin{array}{c}-4.836^{* *} \\
{[2.306]}\end{array}$ \\
\hline F-stat & 14.40 & 14.40 & 14.40 & 14.40 & 14.40 & 14.40 \\
\hline J-stat (p-value) & 0.618 & 0.569 & 0.345 & 0.376 & 0.537 & 0.563 \\
\hline
\end{tabular}

Note: All regressions include a dummy variable for the three departments which had no steam engine in 1860-1865. Aerial distances are measured in kilometers. Other explanatory variables, except the dummies, are in logarithm. Geographic characteristics include the department's latitude, land suitability, average rainfall and temperature, share of carboniferous area, distance to Paris as well as dummies for the presence of rivers and tributaries, maritime and border departments. Institutional measures include dummies for Alsace-Lorraine and for Paris and its suburbs. Pre-industrial development characteristics include a measure of the urban population in 1700 . Robust standard errors are reported in brackets. *** indicates significance at the $1 \%-l$ level, ** at the $5 \%$-level, * at the $10 \%$-level. 
Table D.4: Industrialization and human capital formation: the role of public expenditure on education

\begin{tabular}{|c|c|c|c|c|c|c|}
\hline & $\begin{array}{c}(1) \\
\text { OLS } \\
\text { Log Spending on Primary Schooling } \\
\text { 1874-1882 per Capita } \\
\end{array}$ & $\begin{array}{c}\text { (2) } \\
\text { IV } \\
\text { Log Share }\end{array}$ & \begin{tabular}{l}
\multicolumn{1}{c}{$(3)$} \\
IV \\
cerate Conscripts, \\
-1883 \\
\end{tabular} & $\begin{array}{c}(4) \\
\text { OLS } \\
\text { Log Spending on Secondary Schooling } \\
\text { Schooling 2010 per Capita } \\
\end{array}$ & $\begin{array}{c}\text { (5) } \\
\text { IV } \\
\text { Log Schoo } \\
\text { Age }\end{array}$ & $\begin{array}{l}\text { (6) } \\
\text { IV } \\
\text { ollment of Men } \\
7 \text { in } 2010 \\
\end{array}$ \\
\hline $\begin{array}{l}\text { Log Horse Power of Steam Engines } \\
\text { Log Spending on Primary Schooling } \\
1874-1882 \text { per Capita } \\
\text { Log Spending on Secondary Schooling } \\
2010 \text { per Capita }\end{array}$ & $\begin{array}{c}0.0213 \\
{[0.0281]}\end{array}$ & $\begin{array}{c}0.0582^{* * * *} \\
{[0.0187]}\end{array}$ & $\begin{array}{c}0.0582^{* * *} \\
{[0.0193]} \\
0.0607^{*} \\
{[0.0351]}\end{array}$ & $\begin{array}{l}-0.0065 \\
{[0.0329]}\end{array}$ & $\begin{array}{c}-0.929 * * * \\
{[0.260]}\end{array}$ & $\begin{array}{c}-0.852^{* * * *} \\
{[0.255]}\end{array}$ \\
\hline $\begin{array}{l}\text { Geographic characteristics } \\
\text { Institutional characteristics } \\
\text { Pre-industrial development }\end{array}$ & $\begin{array}{l}\text { Yes } \\
\text { Yes } \\
\text { Yes }\end{array}$ & $\begin{array}{l}\text { Yes } \\
\text { Yes } \\
\text { Yes }\end{array}$ & $\begin{array}{l}\text { Yes } \\
\text { Yes } \\
\text { Yes }\end{array}$ & $\begin{array}{l}\text { Yes } \\
\text { Yes } \\
\text { Yes }\end{array}$ & $\begin{array}{l}\text { Yes } \\
\text { Yes } \\
\text { Yes }\end{array}$ & $\begin{array}{l}\text { Yes } \\
\text { Yes } \\
\text { Yes }\end{array}$ \\
\hline $\begin{array}{l}\text { Adjusted R2 } \\
\text { Observations }\end{array}$ & $\begin{array}{c}0.537 \\
86\end{array}$ & 87 & 86 & $\begin{array}{c}-0.013 \\
88\end{array}$ & 89 & 88 \\
\hline \multicolumn{7}{|c|}{ First stage: the instrumented variable is Log Horse Power of Steam Engines } \\
\hline $\begin{array}{l}\text { Distance to Fresnes } \\
\text { Temperature Deviations }\end{array}$ & & $\begin{array}{c}-0.0069^{* *} \\
{[0.0026]} \\
-4.569^{* *} \\
{[2.111]}\end{array}$ & $\begin{array}{c}-0.0070^{* *} \\
{[0.0028]} \\
-4.284^{*} \\
{[2.159]}\end{array}$ & & $\begin{array}{c}-0.0075^{* * *} \\
{[0.0026]} \\
-4.254^{* *} \\
{[2.092]}\end{array}$ & $\begin{array}{c}-0.0077^{* * *} \\
{[0.0028]} \\
-4.480^{*} \\
{[2.435]}\end{array}$ \\
\hline $\begin{array}{l}\text { F-stat } \\
\text { J-stat (p-value) }\end{array}$ & & $\begin{array}{c}13.274 \\
0.912\end{array}$ & $\begin{array}{c}12.341 \\
0.998\end{array}$ & & $\begin{array}{c}13.644 \\
0.123\end{array}$ & $\begin{array}{c}12.407 \\
0.050\end{array}$ \\
\hline
\end{tabular}

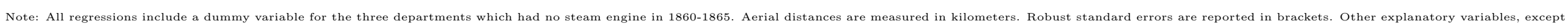

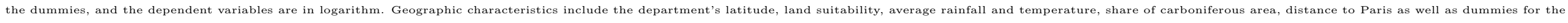

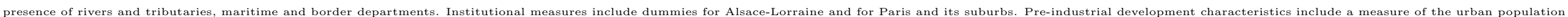
in $1700 .{ }^{* * *}$ indicates significance at the $1 \%$-level, $* *$ at the $5 \%$-level, ${ }^{*}$ at the $10 \%$-level. 


\section{Appendix E. Industrialization and and income per capita, accounting for the population of the department's administrative capital}

Table E.1: Industrialization and income per capita, accounting for the population of the department's administrative capital

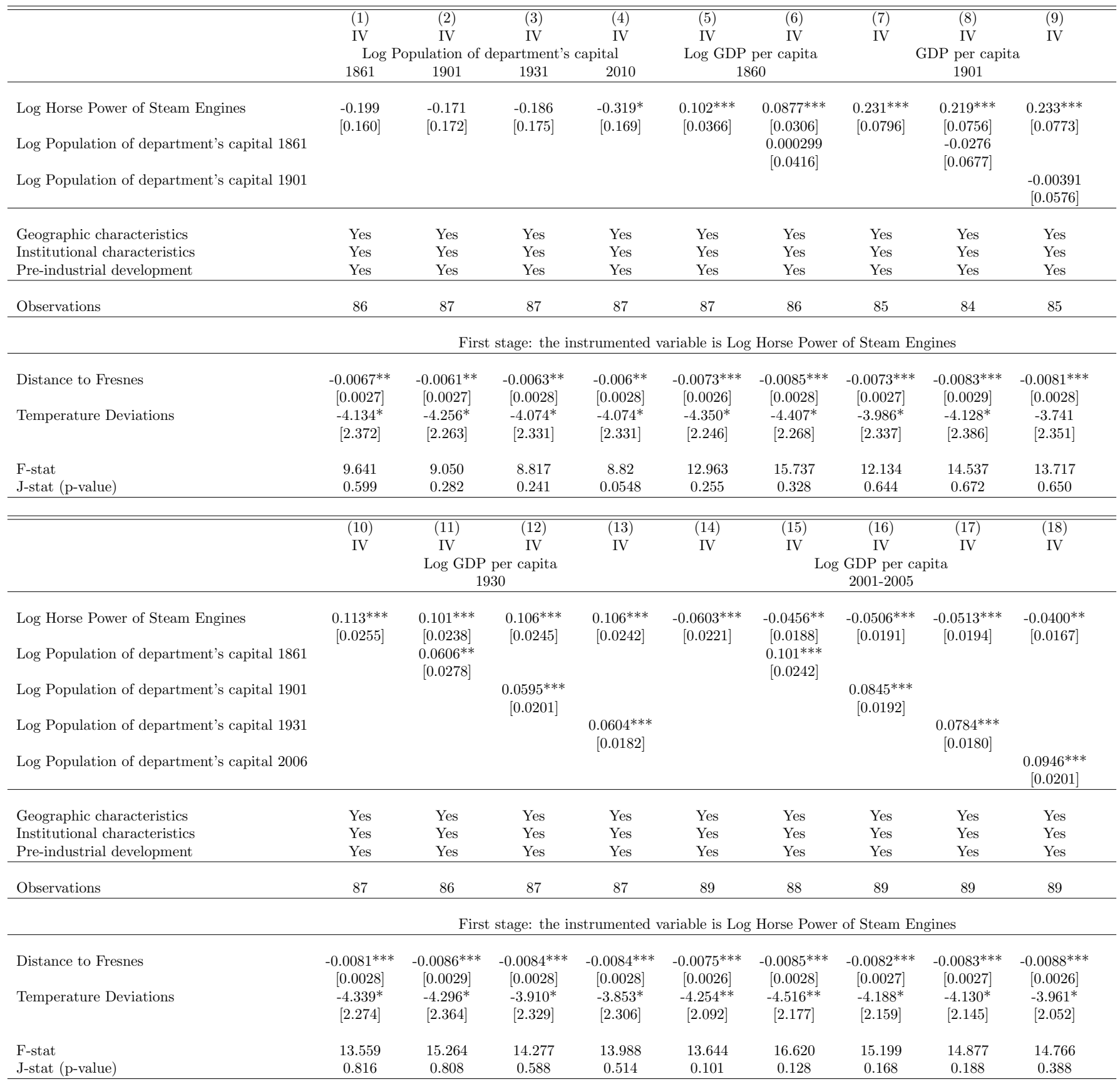

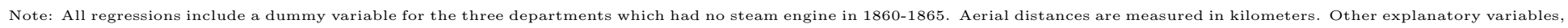

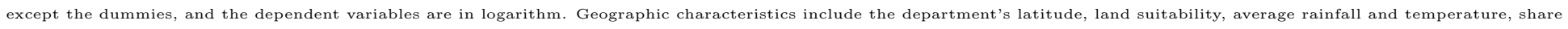

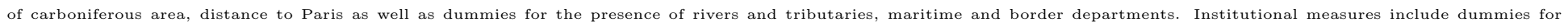

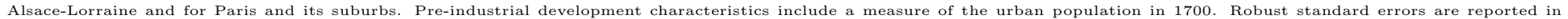
brackets. $* * *$ indicates significance at the $1 \%$-level, $* *$ at the $5 \%$-level, $*$ at the $10 \%$-level. 


\section{Appendix F. Sectoral Tariff Protection and Environmental Regu-}

lation

Table F.1: Industrialization and sectoral tariff protection

\begin{tabular}{|c|c|c|c|c|c|c|c|c|c|c|}
\hline & $\begin{array}{l}(1) \\
\text { OLS }\end{array}$ & $\begin{array}{c}(2) \\
\text { OLS }\end{array}$ & $\begin{array}{c}(3) \\
\text { OLS }\end{array}$ & $\begin{array}{c}(4) \\
\text { OLS }\end{array}$ & $\begin{array}{c}(5) \\
\text { OLS }\end{array}$ & $\begin{array}{c}(6) \\
\text { OLS }\end{array}$ & $\begin{array}{c}(7) \\
\text { OLS }\end{array}$ & $\begin{array}{c}(8) \\
\text { OLS }\end{array}$ & $\begin{array}{c}(9) \\
\text { OLS }\end{array}$ & $\begin{array}{l}\text { (10) } \\
\text { OLS }\end{array}$ \\
\hline & \multicolumn{5}{|c|}{ Log Weighted tariffs across sectors } & \multicolumn{5}{|c|}{ Log Weighted tariffs across sectors, Change } \\
\hline & 1865 & 1901 & 1919 & 1953 & 1970 & 1990 & 2000 & $1953-1970$ & $1970-1990$ & $1990-2000$ \\
\hline Log Horse Power of Steam Engines & $\begin{array}{l}-0.0114 \\
{[0.0482]}\end{array}$ & $\begin{array}{l}-0.0246 \\
{[0.0378]}\end{array}$ & $\begin{array}{c}0.0135 \\
{[0.0186]}\end{array}$ & $\begin{array}{l}-0.0172 \\
{[0.0251]}\end{array}$ & $\begin{array}{l}-0.0138 \\
{[0.0264]}\end{array}$ & $\begin{array}{c}-0.0363^{*} \\
{[0.0216]}\end{array}$ & $\begin{array}{l}-0.0897 \\
{[0.0626]}\end{array}$ & $\begin{array}{c}-0.00216 \\
{[0.0222]}\end{array}$ & $\begin{array}{l}-0.0240 \\
{[0.0259]}\end{array}$ & $\begin{array}{l}-0.0929 \\
{[0.0671]}\end{array}$ \\
\hline Geographic characteristics & Yes & Yes & Yes & Yes & Yes & Yes & Yes & Yes & Yes & Yes \\
\hline Institutional characteristics & Yes & Yes & Yes & Yes & Yes & Yes & Yes & Yes & Yes & Yes \\
\hline Pre-industrial development & Yes & Yes & Yes & Yes & Yes & Yes & Yes & Yes & Yes & Yes \\
\hline Adjusted R2 & 0.069 & -0.034 & -0.003 & -0.059 & -0.032 & 0.150 & 0.212 & -0.055 & 0.081 & 0.105 \\
\hline Observations & 86 & 86 & 86 & 86 & 86 & 86 & 86 & 86 & 86 & 86 \\
\hline
\end{tabular}

Note: All regressions include a dummy variable for the three departments which had no steam engine in 1860-1865. Aerial distances are measured in kilometers. Other explanatory variables, except the dummies, are in logarithm. Geographic characteristics include the department's latitude, land suitability, average rainfall and temperature, share of carboniferous area, distance to Paris as well as dummies for the presence of rivers and tributaries, maritime and border departments. Institutional measures include dummies for Alsace-Lorraine and for Paris and its suburbs. Pre-industrial development characteristics include a measure of the urban population in 1700 . Robust standard errors are reported in brackets. *** indicates significance at the $1 \%-$ level, $* *$ at the $5 \%$-level, * at the $10 \%$-level. 
Table F.2: Industrialization and income per capita, 1860, 1901, 1930 and 2001-2005 accounting for sectoral tariff protection

\begin{tabular}{|c|c|c|c|c|c|c|c|c|c|c|c|c|c|c|c|c|c|c|c|c|c|}
\hline & $\begin{array}{l}(1) \\
\text { IV }\end{array}$ & $\begin{array}{l}(2) \\
\text { IV }\end{array}$ & $\begin{array}{l}(3) \\
\text { IV }\end{array}$ & $\begin{array}{c}(4) \\
\text { IV } \\
1901 \\
\end{array}$ & $\begin{array}{l}(5) \\
\text { IV }\end{array}$ & $\begin{array}{l}(6) \\
\text { IV }\end{array}$ & $\begin{array}{l}(7) \\
\text { IV }\end{array}$ & $\begin{array}{l}(8) \\
\text { IV }\end{array}$ & $\begin{array}{l}(9) \\
\text { IV }\end{array}$ & \multicolumn{3}{|c|}{ Log GDP per capita } & $\begin{array}{l}(13) \\
\text { IV }\end{array}$ & $\begin{array}{l}(14) \\
\text { IV }\end{array}$ & $\begin{array}{c}(15) \\
\text { IV } \\
2001-2005 \\
\end{array}$ & $\begin{array}{l}(16) \\
\text { IV }\end{array}$ & $\begin{array}{l}(17) \\
\text { IV }\end{array}$ & IV & $\begin{array}{l}(19) \\
\text { IV }\end{array}$ & $\begin{array}{l}(20) \\
\text { IV }\end{array}$ & \\
\hline Log Horse Power of Steam Engines & $\begin{array}{l}0.093^{* *} \\
{[0.038]}\end{array}$ & $\begin{array}{l}0.0911 * \\
{[0.036]} \\
0.112]\end{array}$ & $\begin{array}{c}0.214 * * * \\
{[0.082]}\end{array}$ & $\begin{array}{c}0.204^{* * *} \\
{[0.078]} \\
0.131\end{array}$ & $\begin{array}{c}0.208 * * * * \\
{[0.079]}\end{array}$ & $\begin{array}{l}0.092^{* * * *} \\
{[0.027]}\end{array}$ & $\begin{array}{c}0.088^{* * *} * \\
{[0.026]} \\
0.0506\end{array}$ & $\begin{array}{c}0.088 * * * \\
{[0.026]}\end{array}$ & $\begin{array}{l}0.086 * * * \\
{[0.027]}\end{array}$ & $\begin{array}{l}-0.056^{* * *} \\
{[0.021]}\end{array}$ & $\begin{array}{l}-0.055^{* *} \\
{[0.022]} \\
0.0107\end{array}$ & $\begin{array}{c}-0.066 * * * \\
{[0.023]}\end{array}$ & $\begin{array}{l}-0.057 * * * \\
{[0.022]}\end{array}$ & $\begin{array}{c}-0.059^{* * *} \\
{[0.022]}\end{array}$ & $\begin{array}{l}-0.054^{* *} \\
{[0.022]}\end{array}$ & $\begin{array}{c}-0.055^{* * *} \\
{[0.021]}\end{array}$ & $\begin{array}{c}-0.063^{* * *} \\
{[0.023]}\end{array}$ & $\begin{array}{c}-0.055^{* * *} \\
{[0.021]}\end{array}$ & $\begin{array}{c}-0.058^{* * *} * \\
{[0.021]}\end{array}$ & $\begin{array}{c}-0.065^{* * *} \\
{[0.022]}\end{array}$ & \\
\hline Log Weighted tariffs across sectors, 1901 & & {$[0.0760]$} & & {$[0.129]$} & $\begin{array}{c}0.181 \\
{[0.128]}\end{array}$ & & {$[0.0370]$} & $\begin{array}{l}0.0382 \\
{[0.0477]}\end{array}$ & & & {$[0.0534]$} & $\begin{array}{l}-0.0978^{*} \\
{[0.0520]}\end{array}$ & & & & & & & & & \\
\hline Log Weighted tariffs across sectors, 1919 & & & & & & & & & $\begin{array}{l}-0.0101 \\
{[0.0763]}\end{array}$ & & & & $\begin{array}{l}-0.00139 \\
{[0.0694]}\end{array}$ & & & & & & & & \\
\hline Log Weighted tariffs across sectors, 1953 & & & & & & & & & & & & & & $\left.\begin{array}{l}-0.0246 \\
{[0.0602]}\end{array}\right]$ & & & & & & & \\
\hline Log Weighted tariffs across sectors, 1970 & & & & & & & & & & & & & & & $\begin{array}{c}0.0334 \\
{[0.0701]}\end{array}$ & & & & & & \\
\hline Log Weighted tariffs across sectors, 1990 & & & & & & & & & & & & & & & & $\begin{array}{c}0.0305 \\
{[0.0496]}\end{array}$ & & & & & \\
\hline Log Weighted tariffs across sectors, 2000 & & & & & & & & & & & & & & & & & $\begin{array}{r}-0.0265 \\
{[0.0304]}\end{array}$ & & & & \\
\hline Log Weighted tariffs across sectors, Change 1953-1970 & & & & & & & & & & & & & & & & & & $\left.\begin{array}{c}0.0419 \\
{[0.0375]}\end{array}\right]$ & & & \\
\hline Log Weighted tariffs across sectors, Change 1970-1990 & & & & & & & & & & & & & & & & & & & $\begin{array}{c}-0.0114 \\
{[0.0463]}\end{array}$ & & \\
\hline Log Weighted tariffs across sectors, Change 1990-2000 & & & & & & & & & & & & & & & & & & & & $\begin{array}{l}-0.04888^{*} \\
{[0.0267]}\end{array}$ & \\
\hline 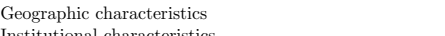 & Yes & Yes & Yes & Yes & Yes & Yes & Yes & Yes & Yes & Yes & $\begin{array}{l}\text { Yes } \\
\text { Yos }\end{array}$ & Yes & Yes & Yes & Yes & Yes & Yes & Yes & Yes & Yes & Yes \\
\hline $\begin{array}{l}\text { Institutional characteristics } \\
\text { Pre-industrial development }\end{array}$ & $\begin{array}{l}\text { Yes } \\
\text { Yes }\end{array}$ & $\begin{array}{l}\text { Yes } \\
\text { Yes }\end{array}$ & $\begin{array}{l}\text { Yes } \\
\text { Yes }\end{array}$ & $\begin{array}{l}\text { Yes } \\
\text { Yes }\end{array}$ & $\begin{array}{l}\text { Yes } \\
\text { Yes }\end{array}$ & $\begin{array}{l}\text { Yes } \\
\text { Yes }\end{array}$ & $\begin{array}{l}\text { Yes } \\
\text { Yes }\end{array}$ & $\begin{array}{l}\text { Yes } \\
\text { Yes }\end{array}$ & $\begin{array}{l}\text { Yes } \\
\text { Yes }\end{array}$ & $\begin{array}{l}\text { Yes } \\
\text { Yes }\end{array}$ & $\begin{array}{l}\text { Yes } \\
\text { Yes }\end{array}$ & $\begin{array}{l}\text { Yes } \\
\text { Yes }\end{array}$ & $\begin{array}{l}\text { Yes } \\
\text { Yes }\end{array}$ & $\begin{array}{l}\text { YYes } \\
\text { Yes }\end{array}$ & $\begin{array}{l}\text { YYes } \\
\text { Yes }\end{array}$ & $\begin{array}{l}\text { YYes } \\
\text { Yes }\end{array}$ & $\begin{array}{l}\text { YYes } \\
\text { Yes }\end{array}$ & $\begin{array}{l}\text { Yes } \\
\text { Yes }\end{array}$ & $\begin{array}{l}\text { YYes } \\
\text { Yes }\end{array}$ & $\begin{array}{l}\text { Yes } \\
\text { Yes }\end{array}$ & $\begin{array}{l}\text { Yes } \\
\text { Yes }\end{array}$ \\
\hline Observations & 87 & 84 & 85 & 82 & 82 & 87 & 84 & 84 & 84 & 89 & 86 & 86 & 86 & 86 & 86 & 86 & 86 & 86 & 86 & 86 & \\
\hline & & & & & & & & First stage & e: Instrumen & ited variable & e- Log Hor: & se Power of & Steam Engi & & & & & & & & \\
\hline Temperature Deviations & 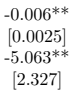 & 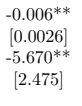 & $\begin{array}{c}-0.006^{* *} \\
{[0.0025]} \\
-4.938^{* *} \\
{[2.380]}\end{array}$ & $\begin{array}{c}-0.006^{* * *} \\
{[0.0026]} \\
-5.496^{* *} \\
{[2.536]}\end{array}$ & $\begin{array}{c}-0.006 * * * \\
{[0.0026]} \\
-5.216 * * \\
{[2.565]}\end{array}$ & $\begin{array}{l}-0.006 * * \\
{[0.0025]} \\
-5.5016 * * \\
{[2.374]}\end{array}$ & $\begin{array}{c}-0.006^{* *} \\
{[0.0026]} \\
-5.611^{* * *} \\
{[2.538]}\end{array}$ & $\begin{array}{c}-0.006^{* *} \\
{[0.0027]} \\
-5.358^{* *} \\
{[2.562]}\end{array}$ & $\begin{array}{c}-0.0066^{* *} \\
{[0.0027]} \\
-5.4733^{* *} \\
{[2.503]}\end{array}$ & $\begin{array}{c}-0.0066^{* * *} \\
{[0.0025]} \\
-4.9666^{* * *} \\
{[2.239]}\end{array}$ & $\begin{array}{c}-0.006 * * \\
{[0.0026]} \\
-5.556 * * \\
{[2.453]}\end{array}$ & $\begin{array}{c}-0.0006^{* * *} \\
{[0.0027]} \\
-5.286^{* * *} \\
{[2.500]}\end{array}$ & $\begin{array}{c}-0.0066^{* * *} \\
{[0.0027]} \\
-5.4077^{* *} \\
{[2.377]}\end{array}$ & $\begin{array}{l}-0.006^{* *} \\
{[0.0027} \\
-5.3992^{* *} \\
{[2.376]}\end{array}$ & $\begin{array}{c}-0.006 * * * \\
{[0.0029]} \\
-5.4222^{* *} \\
{[2.356]}\end{array}$ & $\begin{array}{c}-0.0066^{* * *} \\
{[0.0026]} \\
-4.44411^{* * *} \\
{[2.311]}\end{array}$ & $\begin{array}{c}-0.007^{* * *} * \\
{[0.0026]} \\
-4.464 * * \\
{[2.214]}\end{array}$ & $\begin{array}{c}-0.006^{* *} \\
{[0.0027]} \\
-5.4111^{* *} \\
{[2.386]}\end{array}$ & $\begin{array}{c}-0.007 * * \\
{[0.0027]} \\
-5.5049 * * * \\
{[2.332]}\end{array}$ & $\begin{array}{c}-0.007 * * * \\
{[0.0027]} \\
-4.387 * * \\
{[2.190]}\end{array}$ & \\
\hline $\begin{array}{l}\text { F-stat (1st stage) } \\
\text { J-stat (p-value) }\end{array}$ & $\begin{array}{l}12.917 \\
0.130\end{array}$ & $\begin{array}{l}13.148 \\
0.151\end{array}$ & $\begin{array}{c}11.893 \\
0.374\end{array}$ & $\begin{array}{c}12.017 \\
0.320\end{array}$ & $\begin{array}{l}11.767 \\
0.323\end{array}$ & $\begin{array}{l}12.675 \\
0.088\end{array}$ & $\begin{array}{c}12.821 \\
0.072\end{array}$ & $\begin{array}{c}12.601 \\
0.054\end{array}$ & $\begin{array}{c}12.159 \\
0.051\end{array}$ & $\begin{array}{l}14.861 \\
0.223\end{array}$ & $\begin{array}{c}14.841 \\
0.250\end{array}$ & $\begin{array}{c}14.040 \\
0.584\end{array}$ & $\begin{array}{c}13.601 \\
0.282\end{array}$ & $\begin{array}{c}13.413 \\
0.292\end{array}$ & $\begin{array}{c}13.125 \\
0.316\end{array}$ & $\begin{array}{c}13.149 \\
0.229\end{array}$ & $\begin{array}{c}13.076 \\
0.449\end{array}$ & $\begin{array}{c}14.776 \\
0.328\end{array}$ & $\begin{array}{c}14.422 \\
0.322\end{array}$ & $\begin{array}{c}13.940 \\
0.661\end{array}$ & \\
\hline
\end{tabular}

Note: All regressions include a dummy variable for the three departments which had no steam engine in 1860-1865. Aerial distances are measured in kilometers. Other explanatory variables, except the dummies, are in logarithm. Geographic characteristics include the department's latitude, land suitability, average rainfall and temperature, share of carboniferous area, distance to Paris as well as dummies for the presence of rivers and tributaries, maritime and border departments. Institutional measures include dummies for Alsace-Lorraine and for Paris and its suburbs. Pre-industrial development characteristics include a measure of the urban population in 1700 . Robust standard errors are reported in brackets. $* * *$ indicates significance at the $1 \%$-level, $* *$ at the $5 \%$-level, $*$ at the $10 \%$-level. 
Table F.3: Industrialization and income per capita, accounting for environmental regulation

\begin{tabular}{|c|c|c|c|c|c|}
\hline & $\begin{array}{c}(1) \\
\text { IV } \\
\text { Log CO2 Emission } 2005 \\
\end{array}$ & $\begin{array}{c}(2) \\
\text { IV } \\
\text { Log Ratio CO2 Quota 2012 over Emission } 2005 \\
\end{array}$ & $\begin{array}{l}\text { (3) } \\
\text { IV } \\
\text { Log GDP }\end{array}$ & $\begin{array}{c}\text { (4) } \\
\text { IV } \\
\text { per capita }\end{array}$ & $\begin{array}{c}\text { (5) } \\
\text { IV } \\
2001-2005 \\
\end{array}$ \\
\hline $\begin{array}{l}\text { Log Horse Power of Steam Engines } \\
\text { Log CO2 Emission } 2005\end{array}$ & $\begin{array}{c}0.627^{* * *} \\
{[0.218]}\end{array}$ & $\begin{array}{c}-0.012 \\
{[0.0214]}\end{array}$ & $\begin{array}{c}-0.056^{* * *} \\
{[0.0213]}\end{array}$ & $\begin{array}{c}-0.053^{* * *} \\
{[0.0201]} \\
0.0147^{* * *} \\
{[0.0044]}\end{array}$ & $\begin{array}{c}-0.049^{* *} \\
{[0.0205]}\end{array}$ \\
\hline Log Ratio CO2 Quota 2012 over Emission 2005 & & & & & $\begin{array}{c}0.0711 \\
{[0.0731]}\end{array}$ \\
\hline $\begin{array}{l}\text { Geographic characteristics } \\
\text { Institutional characteristics } \\
\text { Pre-industrial development }\end{array}$ & $\begin{array}{l}\text { Yes } \\
\text { Yes } \\
\text { Yes }\end{array}$ & $\begin{array}{l}\text { Yes } \\
\text { Yes } \\
\text { Yes }\end{array}$ & $\begin{array}{l}\text { Yes } \\
\text { Yes } \\
\text { Yes }\end{array}$ & $\begin{array}{l}\text { Yes } \\
\text { Yes } \\
\text { Yes }\end{array}$ & $\begin{array}{l}\text { Yes } \\
\text { Yes } \\
\text { Yes }\end{array}$ \\
\hline $\begin{array}{l}\text { Adjusted R2 } \\
\text { Observations }\end{array}$ & $\begin{array}{c}0.294 \\
89 \\
\end{array}$ & $\begin{array}{c}0.092 \\
89 \\
\end{array}$ & 89 & 89 & 89 \\
\hline \multicolumn{6}{|c|}{ First stage: Instrumented variable - Log Horse Power of Steam Engines } \\
\hline $\begin{array}{l}\text { Distance to Fresnes } \\
\text { Temperature Deviations }\end{array}$ & & & $\begin{array}{c}-0.0064^{* *} \\
{[0.0025]} \\
-4.966^{* *} \\
{[2.239]}\end{array}$ & $\begin{array}{c}-0.0059^{* *} \\
{[0.0025]} \\
-5.340^{* *} \\
{[2.276]}\end{array}$ & $\begin{array}{c}-0.0065^{* *} \\
{[0.0026]} \\
-5.169^{* *} \\
{[2.277]}\end{array}$ \\
\hline $\begin{array}{l}\text { F-stat (1st stat) } \\
\text { J-stat (p-value) }\end{array}$ & & & $\begin{array}{c}14.861 \\
0.223\end{array}$ & $\begin{array}{c}15.960 \\
0.141\end{array}$ & $\begin{array}{c}12.933 \\
0.186\end{array}$ \\
\hline
\end{tabular}

Note: All regressions include a dummy variable for the three departments which had no steam engine in 1860-1865. Aerial distances are measured in kilometers. Other explanatory variables, except the dummies, are in logarithm. Geographic characteristics include the department's latitude, land suitability, average rainfall and temperature, share of carboniferous area, distance to Paris as well as dummies for the presence of rivers and tributaries, maritime and border departments. Institutional measures include dummies for Alsace-Lorraine and for Paris and its suburbs. Pre-industrial development characteristics include a measure of the urban population in 1700 . Robust standard errors are reported in brackets. *** indicates significance at the $1 \%$-level, $* *$ at the $5 \%$-level, * at the $10 \%$-level. 


\section{Appendix G. Average Height of Soldiers in France, 1700-1765}

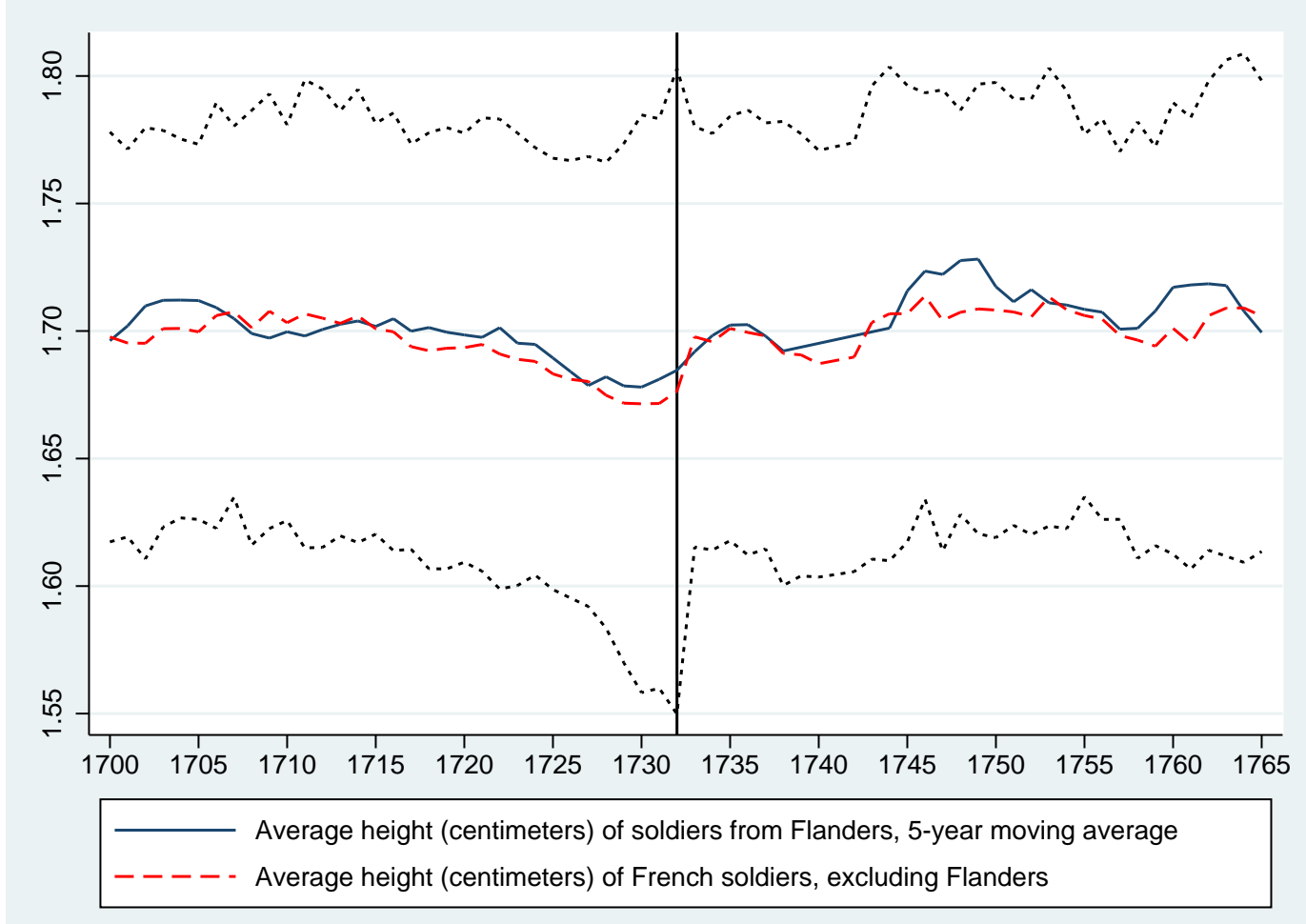

Figure G.2: Average height of soldiers in France, 1700-1765

Note: This figure displays the average mean height of soldiers from Flanders and from the rest of France. The interval between the dotted lines reflects the standard deviation around the national average (excluding Flanders). The vertical line marks the year 1732 when the first commercial application of the steam engine was made in France. 


\section{Appendix H. Variable definitions}

\section{Dependent variables}

\section{Income.}

GDP per capita, 1960 \& 1930. Each department's GDP per capita in 1860 and 1930. Source: Combes et al. (2011).

GDP per capita, 1901. Each department's GDP per capita in 1901. Source: Caruana-Galizia (2013).

GDP per capita, 2001-2005 average. Each department's GDP per capita averaged over the 2001-2005 period. Source: French bureau of statistics (INSEE - Institut National de la Statistique et des Etudes Economiques).

\section{Workforce, Pre-WWII.}

Share of workforce in industry, 1861, 1901, 1931. Each department's share of the workforce in the industrial sector in 1861, 1901 and 1931 (the control group is made of the agricultural sector). Sources: Annuaire Statistique De La France (1878-1939) and Béaur, Gérard, and Béatrice Marin. 2011. La Statistique Générale de la France Présentation. L'Atelier du Centre de recherches historiques. http:acrh.revues.org/index2891.html. Share of workforce in services, 1861, 1901 and 1931. Source: Each department's share of the workforce in the service sector in 1861, 1901 and 1931 (the control group is made of the agricultural sector). Sources: Annuaire Statistique De La France (1878-1939) and Béaur, Gérard, and Béatrice Marin. 2011. La Statistique Générale de la France Présentation. L'Atelier du Centre de recherches historiques. http:acrh.revues.org/index2891.html.

\section{Workforce, Post-WWII.}

Share of workforce in industry, 1968, 1975, 1982, 1990, 1999 and 2010. The share of the workforce working in the industrial sector (the control group is made of the agricultural sector). Source: The successive censuses conducted by the French bureau of statistics (INSEE - Institut National de la Statistique et des Etudes Economiques) in 1968, 1975, 1982, 1990, 1999 and 2010.

Share of workforce in services, 1968, 1975, 1982, 1990, 1999 and 2010. The share of the workforce working in the service sector (the control group is made of the agricultural sector). Source: The successive censuses conducted by the French bureau of statistics (INSEE - Institut National de la Statistique et des Etudes Economiques) in 1968, 1975, 1982, 1990, 1999 and 2010.

Share of Executives in Workforce (age 25-54), 1968, 1975, 1982, 1990, 1999 and 2010. The share of executives and other intellectual professions (i.e, engineers, executives, journalists, wage-earners in the arts, information, entertainment sectors, secondary school and university teachers) in the workforce age 25-54. Individuals in this group have a high-level of human capital. Source: The successive censuses conducted by the French bureau of statistics (INSEE - Institut National de la Statistique et des Etudes Economiques) in 1968, 1975, 1982, 1990, 1999 and 2010.

Share of Intermediary Professionals in Workforce (age 25-54), 1968, 1975, 1982, 1990, 1999 and 2010. Source: The share of middle management professionals (i.e., technicians, foremen, supervisors, primary school teachers, nurses) and employees (unqualified or qualified industrial and farm workers, as well as workers working for craftsmen) in the workforce age 25-54. Individuals in this group have a medium-level of human capital. Source: The successive censuses conducted by the French bureau of statistics (INSEE Institut National de la Statistique et des Etudes Economiques) in 1968, 1975, 1982, 1990, 1999 and 2010.

Share of Employees in Workforce (age 25-54), 1968, 1975, 1982, 1990, 1999 and 2010. The share of employees (unqualified or qualified industrial and farm workers, as well as workers working for craftsmen) 
in the workforce age 25-54. Individuals in this group have a low-level of human capital (the control group is made of farmers, artisans and other self-employed individuals). Source: The successive censuses conducted by the French bureau of statistics (INSEE - Institut National de la Statistique et des Etudes Economiques) in 1968, 1975, 1982, 1990, 1999 and 2010.

\section{Education Measures, Pre-WWI.}

Share of literate individuals among conscripts, 1874-1883, 1894-1903 and 1910-1912. The average share of French army conscripts, i.e., 20-year-old men who reported for military service in the department where their father lived, who could read and write, computed over the 1874-1883, 1894-1903 and 1910-1912 periods. Source:Annuaire Statistique De La France (1878-1939).

\section{Education Measures, Post-WWII.}

Share of men age 25 and above with a post-secondary degree, 1968, 1975, 1982, 1990, 1999 and 2010. The share of men age 25 and above in the population of each department who completed a post-secondary degree (in a vocational school or in an university). Source: The successive censuses conducted by the French bureau of statistics (INSEE - Institut National de la Statistique et des Etudes Economiques) in 1968, 1975, 1982, 1990, 1999 and 2010.

Share of women age 25 and above with a post-secondary degree, 1968, 1975, 1982, 1990, 1999 and 2010. The share of women age 25 and above in the population of each department who completed a post-secondary degree (in a vocational school or in an university). Source: The successive censuses conducted by the French bureau of statistics (INSEE - Institut National de la Statistique et des Etudes Economiques) in 1968, 1975, 1982, 1990, 1999 and 2010.

School enrollment of men/women age 15-17/18-24, in 2010. The shares of men and women in the age groups 15-17 and 18-24 enrolled in an educational institution. Source: The successive censuses conducted by the French bureau of statistics (INSEE - Institut National de la Statistique et des Etudes Economiques) in 2010.

\section{Share of Individuals who Express No Interest in Science, 2001}

Individuals who Express No Interest in Science, 2001. Individuals in each French department who express no interest in science. Source: Centre de recherches politiques de Sciences Po, Enquête science 2001. Use of Science in Work. Individuals in each French department who report not using science in their work. Source: Centre de recherches politiques de Sciences Po, Enquête science 2001.

\section{Department (Public) Spending on Education, per Inhabitant}

Department Spending on Primary Schooling 1874-1882 (in French francs), per Inhabitant. Sources: Annuaire Statistique De La France (1878-1939) and Béaur, Gérard, and Béatrice Marin. 2011. La Statistique Générale de la France Présentation. L'Atelier du Centre de recherches historiques. http:acrh.revues.org/index2891.html.

Department Spending on Secondary Schooling 20001 (in euros), per Inhabitant. Average spending per capita by the departmental governments in 2001. Source: Département des Etudes et Statistiques Locales - DGCL Comptes administratifs 2001 des départements

\section{Work sector, 2008}

Accomodation \& Catering. Source: This dummy variable takes the value 1 if the survey respondent is salaried by a firm in accommodation \& catering. Déclaration Annuelle de Donnés Sociales, INSEE, 2008. 
Arts 8 Entertainment. This dummy variable takes the value 1 if the survey respondent is salaried by a firm of the arts \& entertainment sector. Source: Déclaration Annuelle de Donnés Sociales, INSEE, 2008.

Coal Industries. This dummy variable takes the value 1 if the survey respondent is salaried by a firm of the coal industrial sector. Source: Déclaration Annuelle de Donnés Sociales, INSEE, 2008.

Electrical Appliances. This dummy variable takes the value 1 if the survey respondent is salaried by a firm in the production and distribution of electrical appliances. Source: Déclaration Annuelle de Donnés Sociales, INSEE, 2008.

Machinery Repair. Source: This dummy variable takes the value 1 if the survey respondent is salaried by a firm of the machinery repair sector. Déclaration Annuelle de Donnés Sociales, INSEE, 2008.

Metallurgy Industries. Source: This dummy variable takes the value 1 if the survey respondent is salaried by a firm in the metallurgy sector. Déclaration Annuelle de Donnés Sociales, INSEE, 2008.

Real Estate. Source: This dummy variable takes the value 1 if the survey respondent is salaried by a firm in the real estate sector. Déclaration Annuelle de Donnés Sociales, INSEE, 2008.

Scientific RÉD. This dummy variable takes the value 1 if the survey respondent is salaried by a firm in the scientific research and development sector. Source: Déclaration Annuelle de Donnés Sociales, INSEE, 2008.

Wood Industries. This dummy variable takes the value 1 if the survey respondent is salaried by a firm in the wood industrial sector. Source: Déclaration Annuelle de Donnés Sociales, INSEE, 2008.

\section{Educational Achievement of Second-Generation Migrants, 2005}

Vocational Certificate (Pre-High School). This dummy variable takes the value 1 if the survey respondent's highest educational degree is a Certificat d'Aptitude Professionnelle, a professional degree usually obtained in a professional school around age 14-15. Source: Enquête Emploi, INSEE, 2005.

Business owners $\mathbb{E}$ self-employed. This dummy variable takes the value 1 if the survey respondent is selfemployed and/or is a business owner. Source: Enquête Emploi, INSEE, 2005.

Age. This variable indicates the age of the survey's respondent. Source: Enquête Emploi, INSEE, 2005.

Female. This dummy variable takes the value 1 if the survey respondent is a woman. Source: Enquête Emploi, INSEE, 2005.

\section{Explanatory variables}

Horse power of steam engines. This variable reports the total horse power of the steam Engines in the firms of each department, which is computed from the industrial survey carried out by the French government between 1860 and 1865. See Chanut et al. (2000) for details on the implementation of this survey.

Average rainfall. The average rainfall in $\mathrm{cm}^{3}$, reported at a half-degree resolution by Ramankutty et al. (2002), across the French departments.

Average temperature. The average temperature (in celsius), reported at a half-degree resolution by Ramankutty et al. (2002), across the French departments.

Latitude. The latitude of the centroid of each French department.

Land Suitability The land suitability index, reported at a half-degree resolution by Ramankutty et al. (2002), across the French departments.

Share of carboniferous area in department. The share of carboniferous area in each department. Source: Fernihough and O'Rourke (2014).

Rivers and Tributaries. This dummy variable takes the value 1 if at least one of the main French rivers or tributaries (whose total length is above $300 \mathrm{~km}$ ) crosses a given department. These are the Rhin, Loire, Meuse, Rhône, Seine, Garonne, Dordogne, Charente and Escaut. 
Maritime department. This dummy variable takes the value one if a French department borders the coastline and zero otherwise.

Border department. This dummy variable takes the value one if a French department borders one of the foreign countries around France (Belgium, Luxembourg, Germany, Switzerland, Italy and Spain) and zero otherwise.

Distance to Paris. The great circle distance as "the crow flies" from Paris, the capital of France, to the administrative center of each department. This aerial distance is computed in kilometers.

Paris and suburbs. This dummy variable takes the value one for the three departments, i.e., Seine, Seine-etMarne and Seine-et-Oise, which encompass Paris and its suburbs and zero otherwise.

Alsace-Lorraine. This dummy variable takes the value one for the Bas-Rhin, Haut-Rhin and Moselle departments and zero otherwise in all the regressions on post-WWI outcomes since these three departments were under German rule between 1871 and 1918.

Urban population in 1700 (thousand of inhabitants). This variable reports the total population of the major urban centers, i.e., with more than 10,000 inhabitants, in each French department in 1700 using the data in ?, Appendix Bource: Lepetit (1994).

\section{Instrumental variables}

Distance to Fresnes sur Escaut. The great circle distance as "the crow flies" from Fresnes-sur-Escaut, where a steam engine was first successfully operated in France for commercial and industrial purposes from 1732 onwards, to the administrative center of each department. This aerial distance is computed in kilometers.

Squared Temperature Deviations (1856-1859). Squared deviations of temperature in fall 1856-1859 where 1831-1855 is the baseline period. The data are reconstructed by Luterbacher et al. (2004), Luterbacher et al. (2006) and Pauling et al. (2006) for the 1500-1900 period, at a resolution of 0:5 by 0:5 decimal degrees.

\section{Variables for robustness analysis}

\section{Education before 1840}

Percentage of conscripts who could read, 1827-1829 and 1831-1835. Source: Béaur, Gérard, and Béatrice Marin. 2011. La Statistique Générale de la France Présentation. L'Atelier du Centre de recherches historiques. http:acrh.revues.org/index2891.html.

Share of Grooms who Signed their Wedding Licenses, 1686-1690 and 1786-1790. The share of grooms who signed their wedding licenses with their names over the 1686-1690 and 1786-1790 periods (as opposed to those who marked it with a cross). Source: Béaur, Gérard, and Béatrice Marin. 2011. La Statistique Générale de la France Présentation. L'Atelier du Centre de recherches historiques. http:acrh.revues.org/ index2891.html.

University in 1700 and 1793. This dummy variables takes the value 1 if a university was located in the department in 1700 and 1793. Source: Frijhoff (1996).

\section{Religious minorities}

Jews in Population, 1861. Share of Jews in the population in each department. Source: Béaur, Gérard, and Béatrice Marin. 2011. La Statistique Générale de la France Présentation. L'Atelier du Centre de recherches historiques. http:acrh.revues.org/index2891.html.

Protestants in Population, 1861. Share of Protestants in the population in each department. Source: Béaur, Gérard, and Béatrice Marin. 2011. La Statistique Générale de la France Présentation. L'Atelier du Centre de recherches historiques. http:acrh.revues.org/index2891.html. 


\section{Presence of raw material}

Iron forges, 1789 and 1811. The number of iron forges in each department in 1789 and 1811 . Source: Woronoff (1997).

Presence of iron forges, 1789 and 1811. This dummy variable takes the value 1 if there was at least one iron forge in a department in 1789. Source: Woronoff (1997).

Area covered by mines in department. The area covered by coal mines in 1837 in each department. Source: France - Ministère des Travaux Publics (1838). Statistique de l'industrie minérale et des appareils à vapeur en France et en Algérie, Paris.

\section{Economic integration}

Market integration during the French Revolution. The number of external suppliers for each department in the 1790s for the following categories of products: cotton, hosiery, hardware, misc. production goods, misc. consumption goods, linen and hemp, wool and wool cloth, leather products hides and hats, iron, Food items, drinks, paper, wood for industry, fuel (wood and coal). Source: Daudin (2010).

Railroad connection to Paris in 1860. This dummy variable takes the value 1 if the administrative center of the department was connected to the railroad network in 1860. Source: Caron (1997).

\section{Population density}

Population density, 1801, 1831 and 1861. Source for the data on population: Béaur, Gérard, and Béatrice Marin. 2011. La Statistique Générale de la France Présentation. L'Atelier du Centre de recherches historiques. http:acrh.revues.org/index2891.html. The area covered by each department is computed via GIS.

\section{Distance to cities}

Distance to Berlin. The great circle distance as "the crow flies" from Berlin, the capital of England, to the administrative center of each department. This aerial distance is computed in kilometers.

Distance to London. The great circle distance as "the crow flies" from London, the capital of England, to the administrative center of each department. This aerial distance is computed in kilometers.

Distance to Marseille. The great circle distance as "the crow flies" from Marseille to the administrative center of each department. This aerial distance is computed in kilometers.

Distance to Lyon. The great circle distance as "the crow flies" from Lyon to the administrative center of each department. This aerial distance is computed in kilometers.

Distance to Rouen. The great circle distance as "the crow flies" from Rouen to the administrative center of each department. This aerial distance is computed in kilometers.

Distance to Mulhouse. The great circle distance as "the crow flies" from Mulhouse to the administrative center of each department. This aerial distance is computed in kilometers.

Distance to Bordeaux. The great circle distance as "the crow flies" from Bordeaux to the administrative center of each department. This aerial distance is computed in kilometers.

Distance from Paris (weeks of travel). The time needed for a surface travel from Paris to the administrative center of each department measured in weeks of travel. Source: Özak (2010).

Distance from Marseille (weeks of travel). The time needed for a surface travel from Marseille to the administrative center of each department measured in weeks of travel. Source: Özak (2010).

Distance from Lyon (weeks of travel). The time needed for a surface travel from Lyon to the administrative center of each department measured in weeks of travel. Source: Özak (2010). 
Distance from Rouen (weeks of travel). The time needed for a surface travel from Rouen to the administrative center of each department measured in weeks of travel. Source: Özak (2010).

Distance from Mulhouse (weeks of travel). The time needed for a surface travel from Mulhouse to the administrative center of each department measured in weeks of travel. Source: Özak (2010).

Distance from Bordeaux (weeks of travel). The time needed for a surface travel from Bordeaux to the administrative center of each department measured in weeks of travel. Source: Özak (2010).

\section{Share of the native population}

Share of the native population in each department, 1901. This variable is constructed as the share of the population born in a given department, out of the total population inhabiting this department in the 1901 census of the French population. Source: Annuaire Statistique De La France (1878-1939).

Share of the native population in each department, 2010. This variable is constructed as the share of the population born in a given department, out of the total population inhabiting this department in the 2010 census of the French population. Source: (INSEE - Institut National de la Statistique et des Etudes Economiques).

\section{Building Destruction in World Wars}

World War I Building Destruction. Number of buildings destroyed in World War I. Source: Michel (1926, 1932).

World War I Building Destruction. Number of buildings destroyed in World War II. Source: France (1995). Population 1911. Number of inhabitants in each department. Source: General Census of the French Population, 1911.

Population 1936. Number of inhabitants in each department. Source: General Census of the French Population, 1936.

\section{Share of unionized workers in workforce}

Share of unionized workers in workforce, 1930. The share of individuals in the workforce who belonged to an union in 1930 in each department. Source: Annuaire Statistique De La France (1878-1939).

\section{Average wage, 1901 (in French Francs)}

Average adult wage, 1901. Each department's average wage for men and women in 1901. Source: France. Ministère du travail et de la prévoyance sociale (1911).

\section{Industrial concentration and firm size}

Concentration index. This variable computes the Herfindahl index of industry concentration for each department using the 16 different industries listed in the 1860-1865 industrial survey (textile, mines, metallurgy, metal objects, leather, wood, ceramics, chemistry, construction, lighting, furnitures, clothing, food, transportation, sciences \& arts, and luxury goods). The Herfindahl index of industry concentration is defined as, $H_{d}=\sum_{i=1}^{16}\left(E_{i, d} / E_{d}\right)^{2}$, where $H_{d}$ is the Herfindahl concentration index for department $d, E_{i, d}$ is the horse power of the steam engines in the firms in sector $i$ of department $d$ and $E_{d}$ is the horse power of the steam engines in the firms of department $d$. Source: Chanut et al. (2000). 
Concentration Index - Share of Employees in Industry. This variable computes the Herfindahl index of the share of employees in each of the 16 different industries listed in the 1860-1865 industrial survey (textile, mines, metallurgy, metal objects, leather, wood, ceramics, chemistry, construction, lighting, furnitures, clothing, food, transportation, sciences \& arts, and luxury goods) for each department. This Herfindahl index of is defined as, $H_{d}=\sum_{i=1}^{16}\left(W_{i, d} / W_{d}\right)^{2}$, where $H_{d}$ is the Herfindahl concentration index for department $d$, $W_{i, d}$ is the number of the employees in the firms in sector $i$ of department $d$ and $W_{d}$ is the total number of employees in the firms of department $d$. Source: Chanut et al. (2000).

Number of Employees per Firm 1861-1865. This variable computes the average number of employees per firm in 1860-1865. Source: Chanut et al. (2000).

\section{Weighted tariffs across sectors}

Weighted tariffs across sectors. The weighted average of the tariff rates for each of the 16 sectors listed in the 1860-1865 industrial survey (textile, mines, metallurgy, metal objects, leather, wood, ceramics, chemistry, construction, lighting, furnitures, clothing, food, transportation, sciences \& arts, and luxury goods) in 1865, 1901 and 1919, 1953, 1970, 1990 and 2000 where the weights by the shares of the horse power of the steam engine horse in each department. Source: Chanut et al. (2000) for the industrial survey and Dormois (2009) for the tariffs in 1865, 1901 and 1919, Brown and Irwin (2017) for 1953, Guillochon (1982) for 1970 and United Nations on Trade and Development database for 1990 and 2000.

\section{Environmental regulation}

CO2 Emission 2005. Actual levels of $\mathrm{CO} 2$ emission in 2005. Source: EIDER database from the French Ministry of Environment, Energy and See.

Ratio CO2 Quota 2012 over Emission 2005. Ratio of CO2 emission quotas over the actual levels of CO2 emission in 2005. Source: EIDER database from the French Ministry of Environment, Energy and Sea. 


\section{Appendix I. Data Sources}

Annuaire Statistique De La France (1878-1939), Imprimerie Nationale, Paris.

Brown, Chad P. and Douglas A. Irwin (2017), 'The GATT's starting point: tariff levels circa 1947, in B.H. Manfred Elsig and J. Pauwelyn, eds., Assessing the World Trade Organization: Fit for Purpose?', Cambridge University Pres, Cambridge, UK, pp. 45-74.

Caron, François (1997), Histoire des chemins de fer en France: 1740-1883, Fayard, Paris.

Caruana-Galizia, Paul (2013), 'Estimating French regional income: departmental per capita gross value added, 1872- 1911', Research in Economic History 29, 71-95.

Chanut, Jean-Marie, Jean Heffer, Jacques Mairesse and Gilles Postel-Vinay (2000), L'Industrie française au milieu du 19e siècle. Les enquêtes de la Statistique Générale de la France, EHESS, Paris.

Fernihough, Alan and Kevin H. O'Rourke (2014), 'Coal and the European industrial revolution', NBER Working Paper 19802.

Combes, Pierre-Philippe, Miren Lafourcade, Jacques-François Thisse and Jean-Claude Toutain (2011), 'The rise and fall of spatial inequalities in France: a long-run perspective', Explorations in Economic History 48, 243-271.

Dormois, Jean-Pierre (2009), La Défense du travail national: les effets du protectionnisme sur l'industrie en Europe, Presses universitaires Paris Sorbonne, Paris.

France, Direction de la Documentation Française (1995), Restaurer, réformer, agir : la France en 1945, Textes rassemblées par Patrice Liquière, La Documentation Françcaise, Paris, France.

France. Ministère du travail et de la prévoyance sociale (1911), Statistique générale. Salaires et coût de l'existence: à diverses époques, jusqu'en 1910, Imprimerie Nationale, Paris.

Frijhoff, Willem (1996), Patterns, in H. de Ridder-Symoens, ed., 'A History of the University in Europe, Universities in Early Modern Europe (1500-1800), Vol. 2', Cambridge University Press, Cambridge, UK, pp. 43-110.

Furet, Françcois and Jacques Ozouf (1977), Lire et écrire. L'alphabétisation des Français de Calvin à Jules Ferry, Editions de Minuit, Paris, France.

Guillochon, Bernard (1982), 'La France des années 1970 est-elle protectionniste?', Revue économique 33(8), 981-1000.

Lepetit, Bernard (1994), The Pre-Industrial Urban System: France, 1740-1840, Cambridge University Press, Cambridge, UK.

Michel, Edmond (1926), 'La situation financière et l'achèvement de la reconstitution des régions devastées au 31 décembre 1925', Journal de la société statistique de Paris 67, 248-277.

Michel, Edmond (1932), Les dommages de guerre de la France et leur réparation, Berger-Levrault, Paris, France.

Woronoff, Denis (1997), Les forges, 1811, G. Béaur and P. Minard, eds., 'Atlas de la révolution française: Economie, Vol. 10', Editions de l'école des hautes études en sciences sociales, Paris, pp.99-100. 